\title{
Supplementary Materials for
}

\section{Metal-Free, Redox-Neutral, Site-Selective Access to Heteroarylamine via Direct Radical-Radical Cross-Coupling Powered by Visible Light Photocatalysis}

Chao Zhou, ${ }^{\dagger, \S, \#}$ Tao Lei, ${ }^{\dagger, \S, \#}$ Xiang-Zhu Wei, ${ }^{\dagger, \S}$ Chen Ye, ${ }^{\dagger, \S}$ Zan Liu, ${ }^{\dagger, \S}$ Bin Chen, ${ }^{\dagger, \S}$ Chen-Ho Tung, ${ }^{\dagger}, \mathrm{Li}^{-\mathrm{Zhu}} \mathrm{Wu}^{\dagger, \S, *}$

${ }^{\dagger}$ Key Laboratory of Photochemical Conversion and Optoelectronic Materials, Technical Institute of Physics and Chemistry, Chinese Academy of Sciences, Beijing 100190, P. R. China

${ }^{\S}$ School of Future Technology, University of Chinese Academy of Sciences, Beijing 100049, P. R. China

\#These authors contributed equally to this work.

*Corresponding author: E-mail: $\underline{\text { zwu @ mail.ipc.ac.cn. }}$

\section{Table of Contents}

1. Materials and Methods 2

2. General Procedure for Preparation of Photocatalysts and Substrates 3

3. Optimization of Reaction Conditions and General Procedures 9

4. Mechanistic Study 12

5. References $\quad 37$

6. Characterization for All Products 38

7. ${ }^{1} \mathrm{H}$ and ${ }^{13} \mathrm{C}$ Spectra of Products $\quad 59$ 


\section{Materials and Methods}

${ }^{1} \mathrm{H}$ NMR spectra was recorded using a Bruker Avance DPX $400 \mathrm{MHz}$ instrument with tetramethylsilane (TMS) as an internal standard. ${ }^{13} \mathrm{C}$ NMR spectra were obtained at $100 \mathrm{MHz}$ and referenced to the internal solvent signals. Mass spectra were recorded using a Trio-2000 GC-MS spectrometer. The transient absorption spectra were measured using Laser Flash Photolysis Spectrometer, LP980-KS, Edinburgh Instruments, UK. The luminescence spectrum was recorded by steady/transient state Fluorescence Spectrometer, FLS1000, Edinburgh Instruments, UK. UV-vis absorption spectra were obtained from Shimadzu UV-1601 Spectrophotometer. Cyclic voltammograms were obtained on a CHI 660E potentiostat. Commercially available reagents and solvents were used without further purification. Other amines and hydroxylamine derivatives were prepared by using the reported procedure and purified through column chromatography respectively. Blue LEDs $(3 \mathrm{~W}, \lambda=450 \pm 10 \mathrm{~nm}, 145$ $\operatorname{lm} @ 700 \mathrm{~mA}$ ) were used as the irradiation light. 


\section{General procedure for preparation of the photocatalyst and substrates}

$\underline{\text { Method A }}$<smiles>Cc1c(N(c2ccccc2)c2ccccc2)c(F)c(N(c2ccccc2)c2ccccc2)c(N(c2ccccc2)c2ccccc2)c1N(c1ccccc1)c1ccccc1</smiles>

$\mathrm{NaH}(60 \%$ in oil, $0.60 \mathrm{~g}, 15 \mathrm{mmol})$ was added slowly to the flask with a stirred solution of diphenylamine $(1.69 \mathrm{~g}, 10.0 \mathrm{mmol})$ in dry THF $(40 \mathrm{~mL})$ under the Ar at room temperature. After $30 \mathrm{~min}$, tetrafluoroisophthalonitrile $(0.40 \mathrm{~g}, 2.00 \mathrm{mmol})$ was further added. After stirred at room temperature for $12 \mathrm{~h}, 2 \mathrm{~mL}$ water was added to the reaction mixture to quench the excess $\mathrm{NaH}$. The resulting mixture was then concentrated under reduced pressure and washed by water and EtOH to yield the crude product, which was chromatographed on silica to give the corresponding product 3DPAFIPN. The characterization data of 3DPAFIPN was same as the reported ${ }^{2}$ and a crystal structure confirmed the structure (Figure S12).<smiles></smiles>

2,4,6-Tris(diphenylamino)-5-fluoroisophthalonitrile (3DPAFIPN): ${ }^{1} \mathrm{H}$ NMR $\delta$ 7.30-7.20 (12 $\mathrm{H}), 7.11-7.01(6 \mathrm{H}), 7.01-6.93(12 \mathrm{H}) .{ }^{13} \mathrm{CNMR}\left(101 \mathrm{MHz}, \mathrm{CDCl}_{3}\right) \delta 152.48(\mathrm{~d}, J=258.5 \mathrm{~Hz})$, $151.81(\mathrm{~d}, J=3.2 \mathrm{~Hz}), 151.19,145.55,145.33,143.07$ (d, $J=11.1 \mathrm{~Hz}), 129.45,129.37,124.60$, 124.02, 122.76, 122.73, $112.61(\mathrm{~d}, J=3.2 \mathrm{~Hz}), 109.05(\mathrm{~d}, J=3.0 \mathrm{~Hz}) .{ }^{19} \mathrm{~F} \mathrm{NMR}(377 \mathrm{MHz}$, $\left.\mathrm{CDCl}_{3}\right) \delta$-121.30. ESI: Calcd for $\mathrm{C}_{44} \mathrm{H}_{30} \mathrm{FN}_{5}[\mathrm{M}+\mathrm{H}]^{+}:$: 648.2558; found: 648.2558.

$\underline{\text { Method B }}$

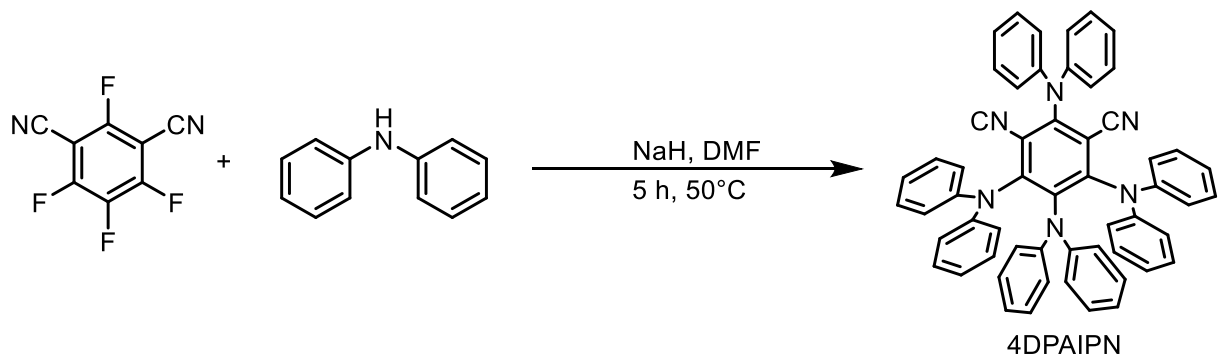

$\mathrm{NaH}$ (60\% in oil, $0.32 \mathrm{~g}, 8 \mathrm{mmol}$ ) was added slowly to a stirred solution of diphenylamine $(1.01 \mathrm{~g}, 6.0 \mathrm{mmol})$ tetrafluoroisophthalonitrile $(0.20 \mathrm{~g}, 1.00 \mathrm{mmol})$ in dry DMF $(10 \mathrm{~mL})$ under a nitrogen atmosphere at room temperature. The deprotonation was firstly performed at $50^{\circ} \mathrm{C}$ for 1 h. After stirring at the same temperature for $4 \mathrm{~h}$, water and ice were added to the reaction mixture 
to quench the excess of $\mathrm{NaH}$. The precipitate was filtered and purified by recrystallization from pentane $/ \mathrm{CH}_{2} \mathrm{Cl}_{2}$ then filtered. The brown liquid filtrate was concentrated and purified by column chromatography on silica gel with DCM/Hexane. The characterization data of 4DPAIPN was same as the reported. ${ }^{3}$

$\underline{\text { Method }} \mathrm{C}^{4}$

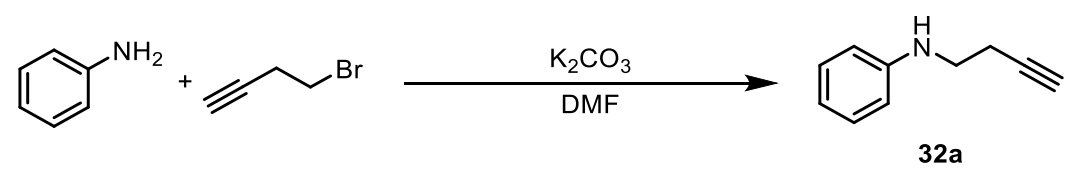

Aniline (10 mmol, $931.3 \mathrm{mg})$ was added to the flask in DMF $(60 \mathrm{ml})$ under the Ar. Then $\mathrm{K}_{2} \mathrm{CO}_{3}$ (10.5 mmol, $1451.2 \mathrm{mg}$ ) and 4-bromo-1-butyne (10.3 mmol, $1370 \mathrm{mg}$ ) were added to the solution. After $12 \mathrm{~h}$ at $85{ }^{\circ} \mathrm{C}$, the mixture was quenched by aqueous $\mathrm{NH}_{4} \mathrm{Cl}$ solution. The aqueous layer was extracted with diethyl ether. The combined organic layers were dried over anhydrous $\mathrm{Na}_{2} \mathrm{SO}_{4}$. Finally, the organic solvent was evaporated in vacuo, and the residue was chromatographed on silica to give the corresponding product.<smiles>C#CCCNc1ccccc1</smiles>

$\boldsymbol{N}$-(but-3-yn-1-yl)aniline (32a): ${ }^{1} \mathrm{H} \mathrm{NMR}\left(400 \mathrm{MHz}, \mathrm{CDCl}_{3}\right) \delta 7.20(\mathrm{t}, J=7.6 \mathrm{~Hz}, 2 \mathrm{H}), 6.74(\mathrm{t}$, $J=7.3 \mathrm{~Hz}, 1 \mathrm{H}), 6.65(\mathrm{~d}, J=8.2 \mathrm{~Hz}, 2 \mathrm{H}), 4.04(\mathrm{bs}, 1 \mathrm{H}), 3.33(\mathrm{t}, J=6.6 \mathrm{~Hz}, 2 \mathrm{H}), 2.51(\mathrm{td}, J=$ 6.5, $2.2 \mathrm{~Hz}, 2 \mathrm{H}), 2.11-1.98(\mathrm{~m}, 1 \mathrm{H}) .{ }^{13} \mathrm{CNMR}\left(101 \mathrm{MHz}, \mathrm{CDCl}_{3}\right) \delta 147.48,129.34,117.99$, 113.25, 81.77, 70.05, 42.56, 19.16. ESI: Calcd for $\mathrm{C}_{10} \mathrm{H}_{11} \mathrm{~N}[\mathrm{M}+\mathrm{H}]^{+}$: 146.0970; found: 146.0962.

$\underline{\text { Method D }}^{5,6}$
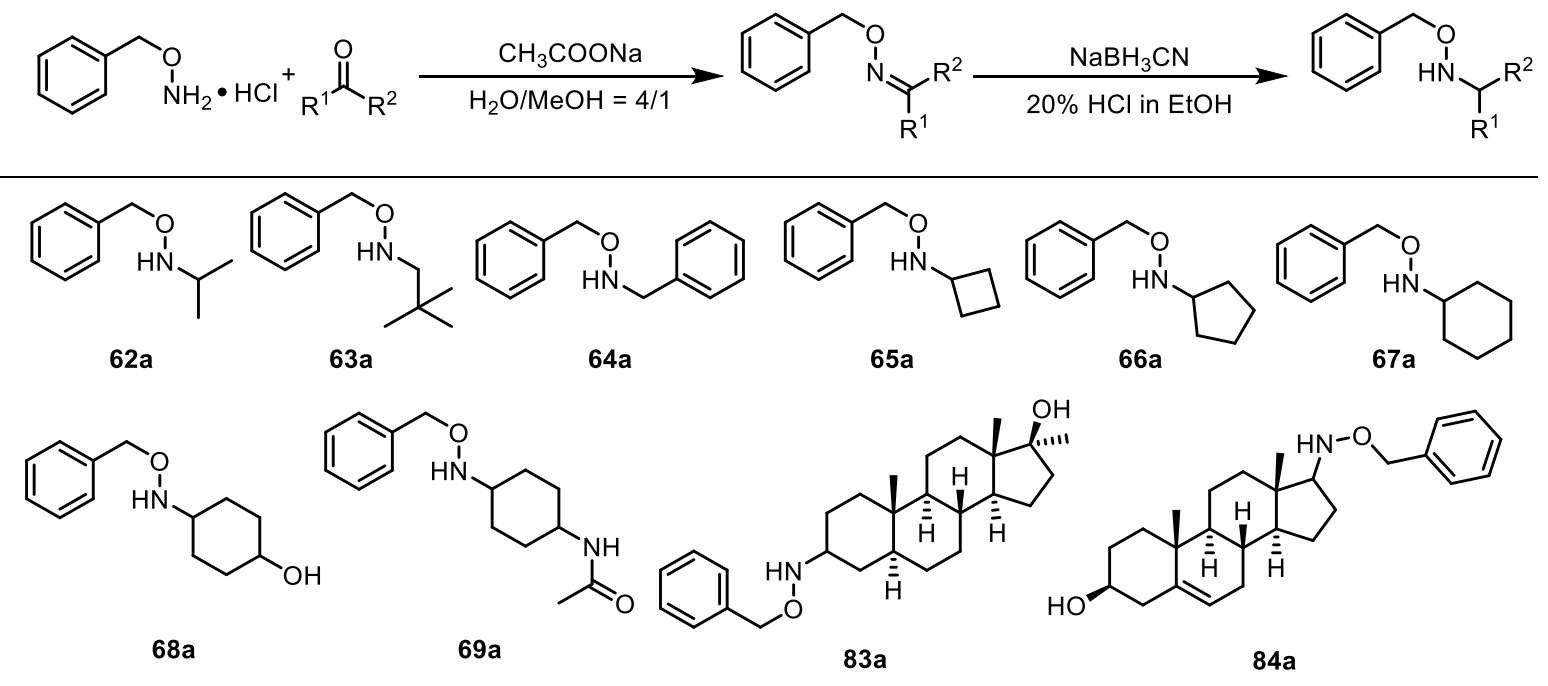

To a stirred solution of sodium acetate (12 mmol, 1.2 equiv.) in $50 \mathrm{~mL} \mathrm{H} 2 \mathrm{O} / \mathrm{MeOH} 4 / 1$ were added $O$-benzylhydroxylamine chlorhydrate (10 mmol, 1 equiv.) and aldehyde or ketone (30 mmol, 3 equiv.). After stirred at room temperature for $12 \mathrm{~h}$, the reaction mixture was extracted 
with $\mathrm{CH}_{2} \mathrm{Cl}_{2}(3 \times 50 \mathrm{~mL})$. The combined organic layers were dried over anhydrous $\mathrm{Na}_{2} \mathrm{SO}_{4}$. Finally, the organic solvent was evaporated in vacuo, and the residue was used without further purification.

Crude oxime was dissolved in $\mathrm{EtOH}$ to a final concentration of $1.5 \mathrm{M}$. Then, the reaction mixture was cooled to $0{ }^{\circ} \mathrm{C}, 5$ equivalents of $\mathrm{NaBH}_{3} \mathrm{CN}$ were added, and the solution was stirred for 15 min. Next, an equal volume of $20 \% \mathrm{HCl}$ in $\mathrm{EtOH}$ chilled to $0{ }^{\circ} \mathrm{C}$ was subsequently added in a drop-wise fashion over $10 \mathrm{~min}$. The reaction was then allowed to warm to room temperature and stirred overnight. Finally, the reaction was neutralized with the addition of $\mathrm{Na}_{2} \mathrm{CO}_{3}$ aqueous solution until the evolution of gas halted. Then the aqueous layer was extracted with $\mathrm{CH}_{2} \mathrm{Cl}_{2}$. The combined organic layers were dried over anhydrous $\mathrm{Na}_{2} \mathrm{SO}_{4}$. Finally, the organic solvent was evaporated in vacuo, and the residue was chromatographed on silica to give the desired oxyamine product (62a-69a and 83a-84a).<smiles>c1ccc(CONC2CCC2)cc1</smiles>

O-benzyl- $\boldsymbol{N}$-cyclobutylhydroxylamine (65a) ${ }^{1} \mathrm{H} \mathrm{NMR}\left(400 \mathrm{MHz}, \mathrm{CDCl}_{3}\right) \delta 7.41-7.25(\mathrm{~m}, 5 \mathrm{H})$, 4.88 (bs, 1H), 4.71 (s, 2 H), 3.68 (p, $J=7.3 \mathrm{~Hz}, 1 \mathrm{H}), 2.13$ (dt, $J=13.1,8.2 \mathrm{~Hz}, 2 \mathrm{H}), 1.92-1.64$ (m, $4 \mathrm{H}) .{ }^{13} \mathrm{CNMR}\left(101 \mathrm{MHz}, \mathrm{CDCl}_{3}\right) \delta 139.60,129.70,129.67,129.07,77.83,57.27,29.14$, 16.69. ESI: Calcd for $\mathrm{C}_{11} \mathrm{H}_{15} \mathrm{NO}[\mathrm{M}+\mathrm{H}]^{+}: 178.1232$; found: 178.1227 .<smiles>OC1CCC(NOCc2ccccc2)CC1</smiles>

4-((benzyloxy)amino)cyclohexanol (68a) ${ }^{1} \mathrm{H} \mathrm{NMR}\left(400 \mathrm{MHz}, \mathrm{CDCl}_{3}\right) \delta 7.42-7.26(\mathrm{~m}, 5 \mathrm{H})$, $4.72(\mathrm{~s}, 2 \mathrm{H}), 3.88(\mathrm{~s}, 1 \mathrm{H}), 3.06-2.90(\mathrm{~m}, 1 \mathrm{H}), 1.79-1.49(\mathrm{~m}, 8 \mathrm{H}) .{ }^{13} \mathrm{CNMR}\left(101 \mathrm{MHz}, \mathrm{CDCl}_{3}\right)$ $\delta$ 137.87, 128.43, 128.38, 127.82, 76.85, 67.30, 57.20, 30.90, 25.08. ESI: Calcd for $\mathrm{C}_{13} \mathrm{H}_{19} \mathrm{NO}_{2}$ $[\mathrm{M}+\mathrm{H}]^{+}:$222.1494; found: 222.1489 .<smiles>CC(=O)NC1CCC(NOCc2ccccc2)CC1</smiles>

$N$-(4-((benzyloxy)amino)cyclohexyl)acetamide (69a) ${ }^{1} \mathrm{H} \mathrm{NMR}\left(400 \mathrm{MHz}, \mathrm{CDCl}_{3}\right) \delta 7.53-7.04$ (m, $5 \mathrm{H}), 5.53-5.25(\mathrm{~m}, 1 \mathrm{H}), 4.67(\mathrm{~s}, 2 \mathrm{H}), 3.84-3.52(\mathrm{~m}, 1 \mathrm{H}), 2.83$ (t, J=10.3 Hz, $1 \mathrm{H}), 2.04$ $1.90(\mathrm{~d}, J=22.8 \mathrm{~Hz}, 7 \mathrm{H}), 1.36-0.98(\mathrm{~m}, 4 \mathrm{H}) .{ }^{13} \mathrm{CNMR}\left(101 \mathrm{MHz}, \mathrm{CDCl}_{3}\right) \delta 169.31,137.79$, 128.38, 128.37, 127.84, 76.93, 58.82, 48.24, 31.31, 29.14, 23.55. HRMS (MALDI-TOF): Calcd for $\mathrm{C}_{15} \mathrm{H}_{22} \mathrm{~N}_{2} \mathrm{O}_{2}[\mathrm{M}+\mathrm{H}]^{+}:$: 263.1760; found: 263.1755 . 


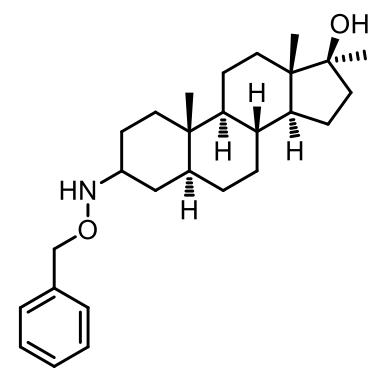

(5S,8R,9S,10S,13S,14S,17S)-3-((benzyloxy)amino)-10,13,17-trimethylhexadecahydro-1H-cy clopenta[a]phenanthren-17-ol (83a): ${ }^{1} \mathrm{H}$ NMR (400 MHz, $\left.\mathrm{CDCl}_{3}\right) \delta$ 7.39-7.27 (m, $\left.5 \mathrm{H}\right), 5.43$ (bs, $1 \mathrm{H}), 4.71$ (s, $2 \mathrm{H}), 3.00-2.81(\mathrm{~m}, 1 \mathrm{H}), 1.85-1.63(\mathrm{~m}, 5 \mathrm{H}), 1.60-1.40(\mathrm{~m}, 5 \mathrm{H}), 1.32-1.10$ $(\mathrm{m}, 13 \mathrm{H}), 0.98(\mathrm{dt}, J=13.4,7.0 \mathrm{~Hz}, 1 \mathrm{H}), 0.91-0.79(\mathrm{~m}, 7 \mathrm{H}), 0.70-0.59(\mathrm{~m}, 1 \mathrm{H}) .{ }^{13} \mathrm{CNMR}$ $\left(101 \mathrm{MHz} \mathrm{CDCl}_{3}\right) \delta 137.98,128.37,128.29,127.75,81.71,76.90,60.17,54.49,50.74,45.56$, 45.22, 39.03, 37.15, 36.43, 36.19, 33.11, 31.83, 31.70, 28.78, 26.35, 25.82, 23.27, 20.78, 13.99, 12.37. EI: Calcd for $\mathrm{C}_{27} \mathrm{H}_{41} \mathrm{NO}_{2}[\mathrm{M}]^{+}$: 411.3137; found: 411.3142 .

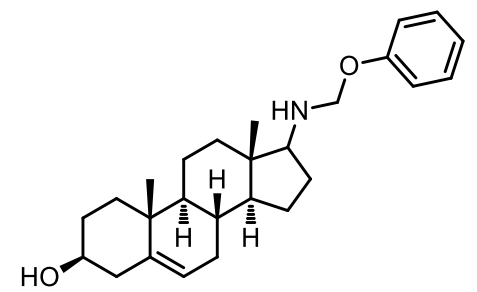

(3S,8R,9S,10R,13S,14S)-10,13-dimethyl-17-((phenoxymethyl)amino)-2,3,4,7,8,9,10,11,12,13, 14,15,16,17-tetradecahydro-1H-cyclopenta[a]phenanthren-3-ol (84a): ${ }^{1} \mathrm{H}$ NMR (400 MHz, $\left.\mathrm{CDCl}_{3}\right) \delta 7.40-7.27(\mathrm{~m}, 5 \mathrm{H}), 5.34(\mathrm{~d}, J=4.1 \mathrm{~Hz}, 1 \mathrm{H}), 4.70(\mathrm{~s}, 2 \mathrm{H}), 3.52(\mathrm{tt}, J=9.9,4.3 \mathrm{~Hz}, 1$ H), 3.08 (t, $J=8.4 \mathrm{~Hz}, 1 \mathrm{H}), 2.36-2.17(\mathrm{~m}, 2 \mathrm{H}), 2.09-1.79(\mathrm{~m}, 5 \mathrm{H}), 1.70-1.38(\mathrm{~m}, 7 \mathrm{H}), 1.32-$ $0.88(\mathrm{~m}, 9 \mathrm{H}), 0.75(\mathrm{~s}, 3 \mathrm{H}) .{ }^{13} \mathrm{CNMR}\left(101 \mathrm{MHz}, \mathrm{CDCl}_{3}\right) \delta 140.99,138.25,128.33,127.66$, 121.43, 121.42, 75.97, 71.80, 70.47, 53.96, 50.42, 42.63, 42.42, 38.53, 37.38, 36.67, 31.89, 31.78, 26.12, 23.87, 20.96, 19.47, 11.73. EI: Calcd for $\mathrm{C}_{26} \mathrm{H}_{37} \mathrm{NO}_{2}[\mathrm{M}]^{+}:$395.2824; found: 395.2830.

The characterization data of other hydroxylamines (62a-64a, 66a-67a) were same as the reported elsewhere ${ }^{5-10}$.

$\underline{\text { Method E }}^{11}$

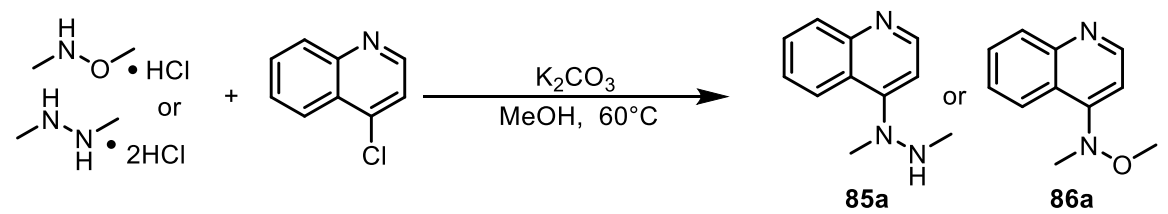

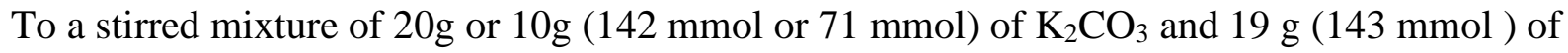
hydrazine hydrochloride or $13.9 \mathrm{~g}$ (143 mmol ) of hydroxylamine hydrochloride in $120 \mathrm{~mL}$

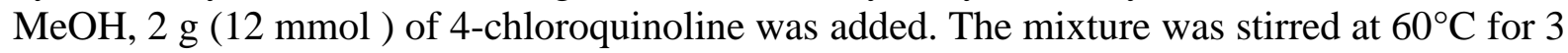
hours. The hot solution was then filtered to remove $\mathrm{KCl}$ and was evaporated in vacuo. Next, the residue was neutralized $1 \mathrm{M} \mathrm{NaOH}$ aqueous solution $(15 \mathrm{~mL})$, and was extracted with $\mathrm{CH}_{2} \mathrm{Cl}_{2}$ 
$(2 \times 100 \mathrm{~mL})$. The combined organic layers were washed by water $(3 \times 100 \mathrm{~mL})$ and dried over anhydrous $\mathrm{Na}_{2} \mathrm{SO}_{4}$. Finally, the organic solvent was evaporated in vacuo to provide heteroaryl hydrazine 85a and hydroxylamine 86a without further purification.<smiles>CNN(C)c1ccnc2ccccc12</smiles>

4-(1,2-dimethylhydrazineyl)quinoline (85a) ${ }^{1} \mathrm{H} \mathrm{NMR}\left(400 \mathrm{MHz}, \mathrm{CDCl}_{3}\right)$ c $\delta 8.68(\mathrm{~d}, J=4.9 \mathrm{~Hz}$, $1 \mathrm{H}), 8.33(\mathrm{~d}, J=8.5 \mathrm{~Hz}, 1 \mathrm{H}), 8.02(\mathrm{~d}, J=8.4 \mathrm{~Hz}, 1 \mathrm{H}), 7.63(\mathrm{t}, J=7.5 \mathrm{~Hz}, 1 \mathrm{H}), 7.45(\mathrm{t}, J=$ $7.6 \mathrm{~Hz}, 1 \mathrm{H}), 6.86(\mathrm{~d}, J=4.9 \mathrm{~Hz}, 1 \mathrm{H}), 3.28(\mathrm{bs}, 1 \mathrm{H}), 3.16(\mathrm{~s}, 3 \mathrm{H}), 2.74(\mathrm{~s}, 3 \mathrm{H}) .{ }^{13} \mathrm{CNMR}(101$ $\left.\mathrm{MHz}_{\mathrm{CDCl}}\right) \delta 156.87,151.01,149.02,129.71,129.19,125.74,123.10,121.85,107.79,60.15$, 46.93. ESI: Calcd for $\mathrm{C}_{11} \mathrm{H}_{13} \mathrm{~N}_{3}[\mathrm{M}+\mathrm{H}]^{+}: 188.1183$; found: 188.1181 .<smiles>CON(C)c1ccnc2ccccc12</smiles>

$\boldsymbol{N}$,O-dimethyl- $\boldsymbol{N}$-(quinolin-4-yl)hydroxylamine (86a) ${ }^{1} \mathrm{H} \mathrm{NMR}\left(400 \mathrm{MHz}, \mathrm{CDCl}_{3}\right) \delta 8.81(\mathrm{~d}, \boldsymbol{J}$ $=4.6 \mathrm{~Hz}, 1 \mathrm{H}), 8.08(\mathrm{~d}, J=8.4 \mathrm{~Hz}, 1 \mathrm{H}), 7.99(\mathrm{~d}, J=8.4 \mathrm{~Hz}, 1 \mathrm{H}), 7.68(\mathrm{t}, J=7.6 \mathrm{~Hz}, 1 \mathrm{H}), 7.51$ $(\mathrm{t}, J=7.5 \mathrm{~Hz}, 1 \mathrm{H}), 7.36(\mathrm{~d}, J=4.7 \mathrm{~Hz}, 1 \mathrm{H}), 3.67(\mathrm{~s}, 3 \mathrm{H}), 3.19(\mathrm{~s}, 3 \mathrm{H}) .{ }^{13} \mathrm{CNMR}(101 \mathrm{MHz}$, $\left.\mathrm{CDCl}_{3}\right) \delta 156.83,151.02,149.03,129.72,129.15,125.72,123.08,121.84,107.78,60.13,46.92$. ESI: Calcd for $\mathrm{C}_{11} \mathrm{H}_{12} \mathrm{~N}_{2} \mathrm{O}[\mathrm{M}+\mathrm{H}]^{+}: 189.1023$; found: 189.1024 .

$\underline{\text { Method }}^{12,13}$

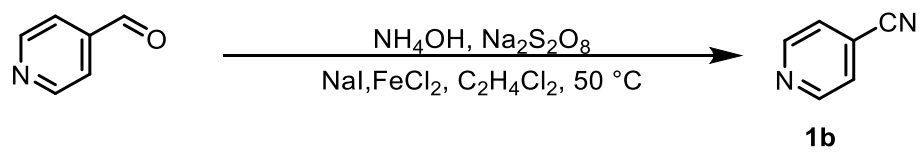

To a solution of aldehydes $(3 \mathrm{mmol})$ in 1,2-dichloroethane $(10 \mathrm{~mL})$ was added $\mathrm{FeCl}_{2}(0.3 \mathrm{mmol})$, $\mathrm{Na}_{2} \mathrm{~S}_{2} \mathrm{O}_{8}(4.5 \mathrm{mmol}), \mathrm{NaI}(0.15 \mathrm{mmol})$, and $\mathrm{NH}_{3} . \mathrm{H}_{2} \mathrm{O}(9 \mathrm{~mL})$ at room temperature. After the mixture was stirred at $50^{\circ} \mathrm{C}$ for 16 hours, it was poured into water $(30 \mathrm{~mL})$ and extracted with DCM $(3 \times 30 \mathrm{~mL})$. The combined organic extracts were washed with brine and dried over anhydrous sodium sulfate. The solvent was removed under reduced pressure. The crude product was purified by column chromatography on silica gel to afford the desired product.

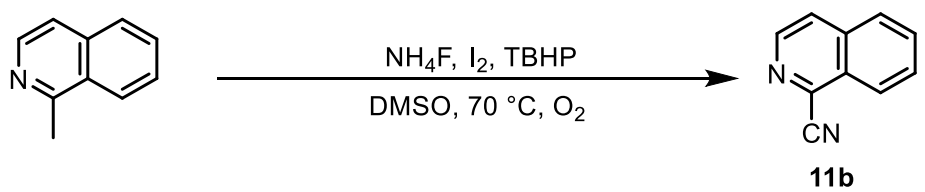

Under $\mathrm{O}_{2}$, a $20 \mathrm{~mL}$ of Schlenk tube equipped with a stir bar was charged with 1-methylisoquinoline (28.6 mg $0.2 \mathrm{mmol}), \mathrm{I}_{2}(10.2 \mathrm{mg}, 0.04 \mathrm{mmol}), \mathrm{NH}_{4} \mathrm{~F}(29.6 \mathrm{mg}, 0.8 \mathrm{mmol})$, TBHP (70\% in water, $324 \mu \mathrm{L}, 2.4 \mathrm{mmol})$, DMSO $(0.5 \mathrm{~mL})$. The tube was sealed with a Teflon lined cap. The reaction mixture was stirred at $70{ }^{\circ} \mathrm{C}$ for $48 \mathrm{~h}$ in oil bath. After the completion of 
the reaction (monitored by TLC), the solvent was concentrated in vacuum and the residue was purified by flash column chromatography on silica gel to give the desired product.

The characterization of $\mathbf{1 b}$ and $\mathbf{1 1 b}$ were the same as the reported elsewhere ${ }^{12-13}$. Cyanated heteroarenes are available from the corresponding heteroaryl aldehyde or methyl heteroarenes with oxidant and ammonium salt. 


\section{Optimization of reaction conditions and general procedures}

Table S1. The optimization for the synthesis of heteroarylamines ${ }^{a}$

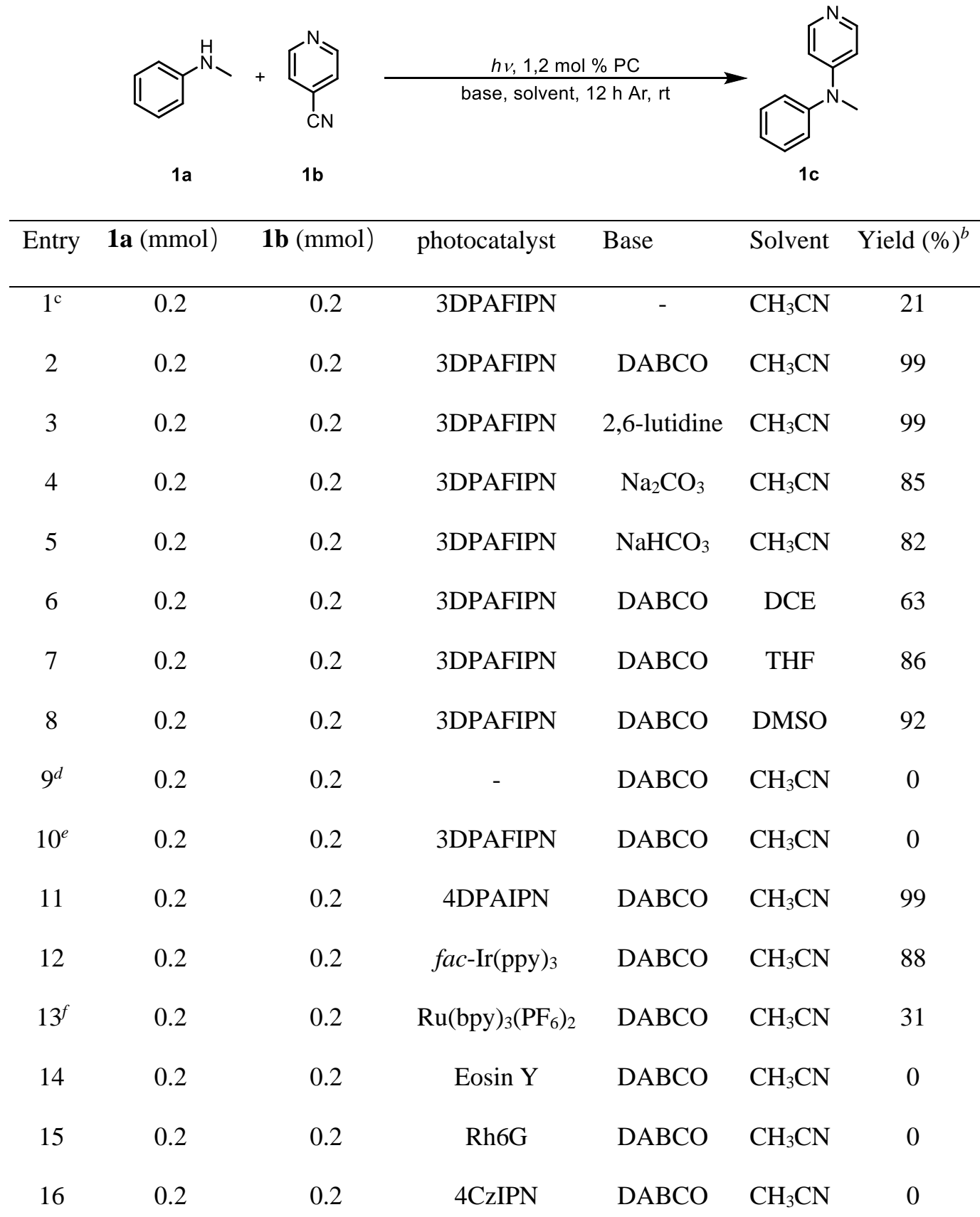

${ }^{a}$ Reaction condition: $0.2 \mathrm{mmol}$ (1 equiv) 1a ( $N$-methylaniline), $0.2 \mathrm{mmol}$ (1 equiv) 1b (isonicotinonitrile), 1.2 mol \% PC, $3 \mathrm{~mL}$ solvent, Ar, blue LEDs, room temperature. ${ }^{b}$ The yields were determined by ${ }^{1} \mathrm{H}$ NMR using diphenylmethano as the internal standard. ${ }^{c}$ no base. ${ }^{d}$ No 3 DPAFIPN. ${ }^{e}$ No light. ${ }^{f}$ Green light. 
General Procedure A for the scope of arylamines

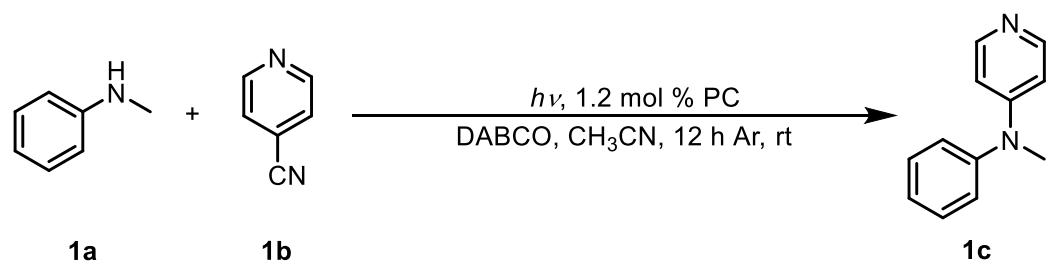

A $10 \mathrm{~mL}$ Pyrex tube equipped with a magnetic stir bar was charged with isonicotinonitrile (20.8 $\mathrm{mg}, 0.2 \mathrm{mmol})$, DABCO (22.4 mg, $0.2 \mathrm{mmol}$ ) and PC (3DPAFIPN) (1.6 mg, $0.0024 \mathrm{mmol})$ in $\mathrm{CH}_{3} \mathrm{CN}(3 \mathrm{~mL})$. After the mixture was strictly deaerated, $N$-methylaniline $(21.7 \mathrm{ul}, 0.2 \mathrm{mmol})$ was added into the mixture which was further irradiated by blue LEDs $(\lambda=450 \mathrm{~nm})$ for 12 hours at room temperature. When reaction was finished, the residue was purified by chromatography on silica gel to get isolated product.

General Procedure B for the gram-scale synthesis

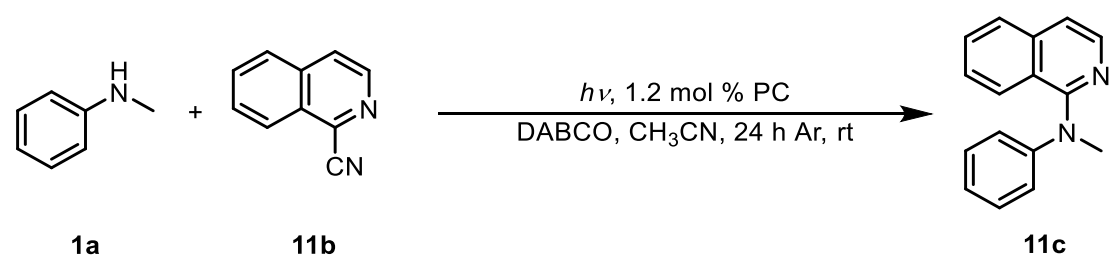

A $100 \mathrm{~mL}$ Pyrex tube equipped with a magnetic stir bar was charged with 1-isoquinolinecarbonitrile (770 mg, $5.0 \mathrm{mmol}), N$-methylaniline (542 ul, $5.0 \mathrm{mmol})$, DABCO (560 mg, $5.0 \mathrm{mmol}$ ) and PC (3DPAFIPN) $(40 \mathrm{mg}, 0.06 \mathrm{mmol})$ in $\mathrm{CH}_{3} \mathrm{CN}(50 \mathrm{~mL})$. The mixture was strictly deaerated and irradiated by blue LEDs $(\lambda=450 \mathrm{~nm})$ for 24 hours at room temperature. When reaction was finished, the system was purified by chromatography on silica gel to get the $1.05 \mathrm{~g}$ product $11 \mathrm{c}$ with $90 \%$ yield.

General Procedure C for the scope of hydroxylamines

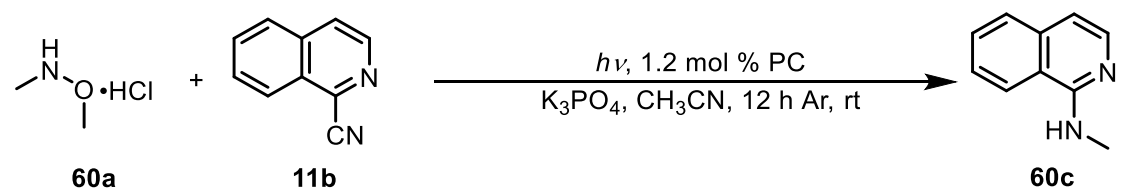

A $10 \mathrm{~mL}$ Pyrex tube equipped with a magnetic stir bar was charged with N,O-dimethylhydroxylamine hydrochloride $(48.8 \mathrm{mg}, 0.5 \mathrm{mmol}), 1$-isoquinolinecarbonitrile (30.8 $\mathrm{mg}, 0.2 \mathrm{mmol}$ ), $\mathrm{K}_{3} \mathrm{PO}_{4}(84.9 \mathrm{mg}, 0.4 \mathrm{mmol})$ and PC (3DPAFIPN) (1.6 mg, $\left.0.0024 \mathrm{mmol}\right)$ in $\mathrm{CH}_{3} \mathrm{CN}(3 \mathrm{~mL})$. After the mixture was strictly deaerated, the mixture was further irradiated by blue LEDs $(\lambda=450 \mathrm{~nm})$ for 12 hours at room temperature. When reaction was finished, the mixture was extracted with EtOAc $(6 \times 5 \mathrm{~mL})$. The combined organic layers were dried over anhydrous $\mathrm{Na}_{2} \mathrm{SO}_{4}$. Finally, the organic solvent was evaporated in vacuo, and the residue was chromatographed on silica to give the desired product.

General Procedure D for the scope of hydrazines 


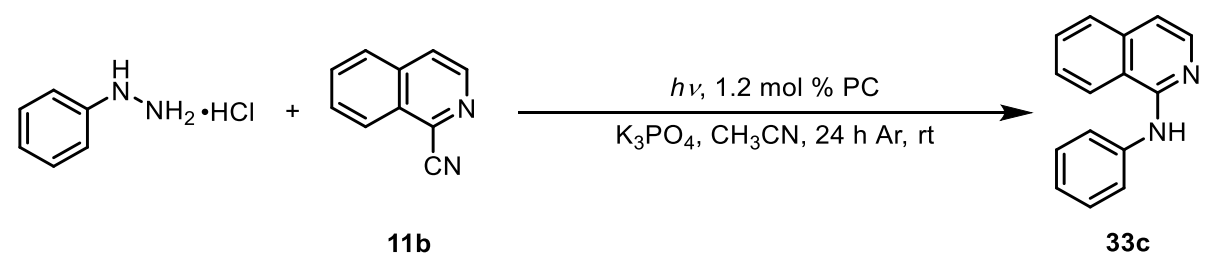

A $10 \mathrm{~mL}$ Pyrex tube equipped with a magnetic stir bar was charged with phenylhydrazine hydrochloride (57.8 mg, $0.4 \mathrm{mmol}$ ), 1-isoquinolinecarbonitrile ( $30.8 \mathrm{mg}, 0.2 \mathrm{mmol}$ ), $\mathrm{K}_{3} \mathrm{PO}_{4}$ (84.9 mg, $0.4 \mathrm{mmol}$ ) and PC (3DPAFIPN) (1.6 mg, $0.0024 \mathrm{mmol})$ in $\mathrm{CH}_{3} \mathrm{CN}(3 \mathrm{~mL})$. After the mixture was strictly deaerated, the mixture was further irradiated by blue LEDs $(\lambda=450 \mathrm{~nm})$ for 24 hours at room temperature. When reaction was finished, the mixture was extracted with EtOAc $(6 \times 5 \mathrm{~mL})$. The combined organic layers were dried over anhydrous $\mathrm{Na}_{2} \mathrm{SO}_{4}$. Finally, the organic solvent was evaporated in vacuo, and the residue was chromatographed on silica to give the desired product.

General Procedure E for the facile last-stage decoration of bioactive compounds

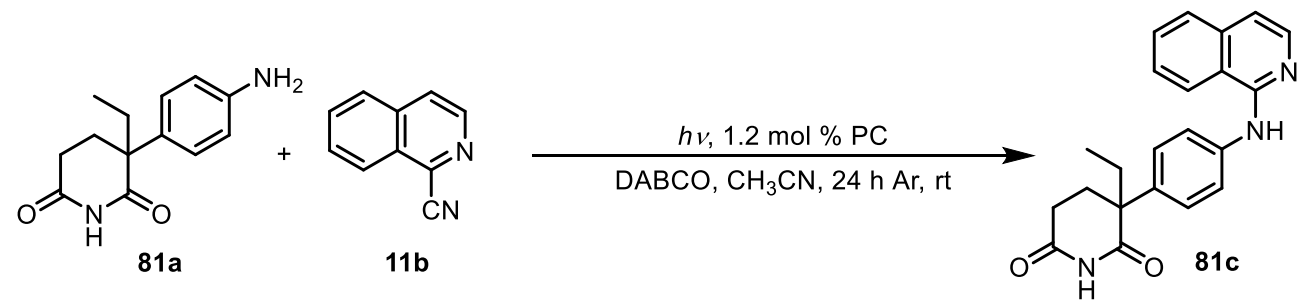

A $10 \mathrm{~mL}$ Pyrex tube equipped with a magnetic stir bar was charged with aminoglutethimide (46.4 mg, $0.2 \mathrm{mmol}$ ), 1-isoquinolinecarbonitrile ( $30.8 \mathrm{mg}, 0.2 \mathrm{mmol}$ ), DABCO (22.4 mg, 0.2 $\mathrm{mmol})$ and PC (3DPAFIPN) $(1.6 \mathrm{mg}, 0.0024 \mathrm{mmol})$ in $\mathrm{CH}_{3} \mathrm{CN}(6 \mathrm{~mL})$. After the mixture was strictly deaerated, the mixture was further irradiated by blue LEDs $(\lambda=450 \mathrm{~nm})$ for 24 hours at room temperature. When reaction was finished, the residue was purified by chromatography on silica gel to get isolated products. 


\section{Mechanistic Study}

\subsection{The system with 3DPAFIPN, 1a and 1b}

Electrochemical and spectroscopic study
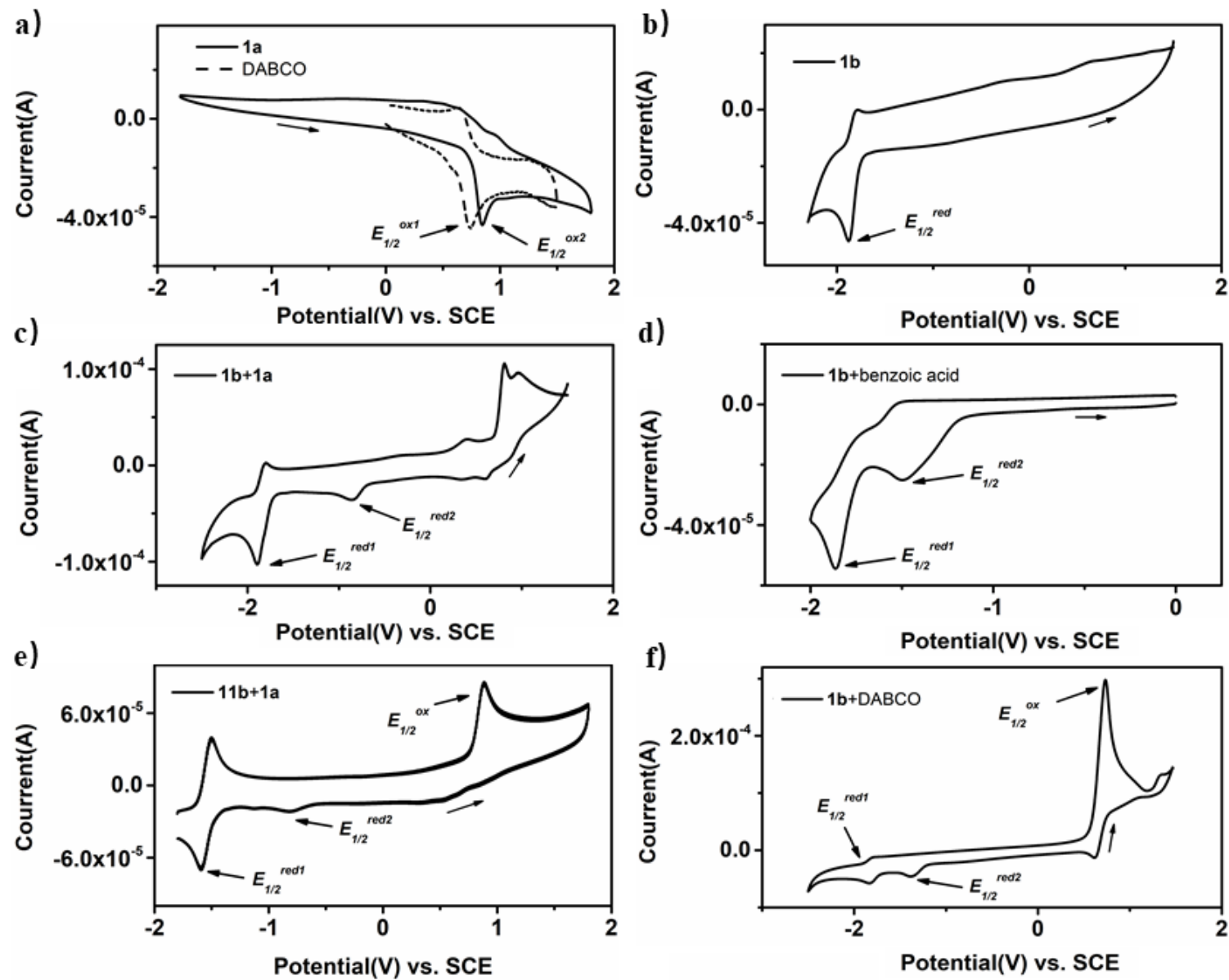

Figure S1. a) The CV experiment of $1 \mathrm{a}\left(1.0 \times 10^{-3} \mathrm{M}\right)$, DABCO $\left(1.0 \times 10^{-3} \mathrm{M}\right)$ and $\mathrm{NBu}_{4} \mathrm{PF}_{6}$ $\left(1.0 \times 10^{-1} \mathrm{M}\right)$ in degassed $\mathrm{CH}_{3} \mathrm{CN}, E_{1 / 2}{ }^{\text {ox1 }}=0.68 \mathrm{~V} \mathrm{SCE}$ for DABCO, $E_{1 / 2}{ }^{\text {ox } 2}=0.92 \mathrm{~V}$ SCE for $\mathbf{1 a}$; b) The CV experiment of $\mathbf{1 b}\left(1.0 \times 10^{-3} \mathrm{M}\right)$ and $\mathrm{NBu}_{4} \mathrm{PF}_{6}\left(1.0 \times 10^{-1} \mathrm{M}\right)$ in degassed $\mathrm{CH}_{3} \mathrm{CN}$, $E_{1 / 2}{ }^{\text {red }}=-1.84 \mathrm{~V} \mathrm{SCE}$; c) The CV experiment of $\mathbf{1 b}\left(1.0 \times 10^{-3} \mathrm{M}\right)$ with $1 \mathbf{a}\left(1.0 \times 10^{-3} \mathrm{M}\right)$ and $\mathrm{NBu}_{4} \mathrm{PF}_{6}\left(1.0 \times 10^{-1} \mathrm{M}\right)$ in degassed $\mathrm{CH}_{3} \mathrm{CN}$, while $\mathbf{1 a}$ was firstly oxidized and then $\mathbf{1 b}$ was reduced, $E_{1 / 2}{ }^{\text {red1 }}=-1.84 \mathrm{~V} \mathrm{SCE}, E_{1 / 2}{ }^{\text {red2 }}=-0.87 \mathrm{~V} \mathrm{SCE}$; d $)$ The CV experiment of $1 \mathbf{b}\left(1.0 \times 10^{-3}\right.$ $\mathrm{M})$ with benzoic acid $\left(1.0 \times 10^{-3} \mathrm{M}\right)$ and $\mathrm{NBu}_{4} \mathrm{PF}_{6}\left(1.0 \times 10^{-1} \mathrm{M}\right)$ in degassed $\mathrm{CH}_{3} \mathrm{CN}, E_{1 / 2}{ }^{\text {red1 }}=$ $-1.84 \mathrm{~V} \mathrm{SCE}, E_{1 / 2}{ }^{\text {red2 }}=-1.49 \mathrm{~V} \mathrm{SCE}$; e) The CV experiment of $\mathbf{1 1 b}\left(1.0 \times 10^{-3} \mathrm{M}\right)$ with $\mathbf{1 a}$ $\left(1.0 \times 10^{-3} \mathrm{M}\right)$ and $\mathrm{NBu}_{4} \mathrm{PF}_{6}\left(1.0 \times 10^{-1} \mathrm{M}\right)$ in degassed $\mathrm{CH}_{3} \mathrm{CN}$, while $\mathbf{1 a}$ was firstly oxidized and then $11 \mathrm{~b}$ was reduced, $E_{1 / 2}{ }^{\text {red1 }}=-1.52 \mathrm{~V} \mathrm{SCE}, E_{1 / 2}{ }^{\text {red2 }}=-0.81 \mathrm{~V} \mathrm{SCE}$; f) The CV experiment of 1b $\left(1.0 \times 10^{-3} \mathrm{M}\right)$ with DABCO $\left(1.0 \times 10^{-3} \mathrm{M}\right)$ and $\mathrm{NBu}_{4} \mathrm{PF}_{6}\left(1.0 \times 10^{-1} \mathrm{M}\right)$ in degassed $\mathrm{CH}_{3} \mathrm{CN}$, while DABCO was firstly oxidized and then $\mathbf{1 b}$ was reduced, $E_{1 / 2}{ }^{\text {red } 1}=-1.84 \mathrm{~V} \mathrm{SCE}, E_{1 / 2}{ }^{\mathrm{red} 2}=$ -1.37 V SCE. 

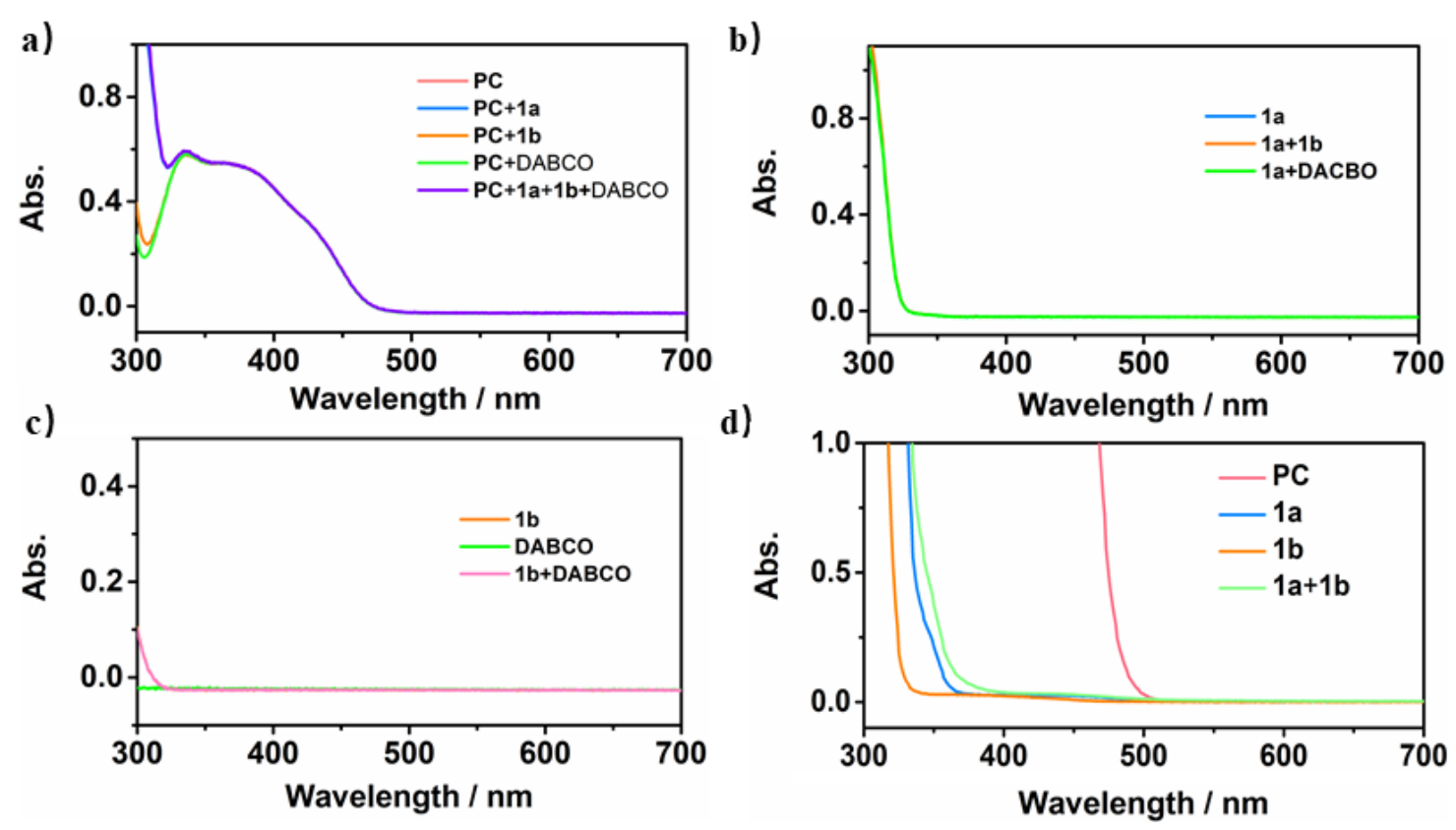

Figure S2. a-c) Absorption spectra of PC (3DPAFIPN) $\left(3.0 \times 10^{-5} \mathrm{M}\right), \mathbf{1 a}\left(5 \times 10^{-4} \mathrm{M}\right), \mathbf{1 b}\left(5 \times 10^{-4}\right.$ $\mathrm{M})$ and $\mathrm{DABCO}\left(5 \times 10^{-4} \mathrm{M}\right)$ and the mixture of $\mathbf{1 a}$ and $\left.\mathbf{1 b} ; \mathrm{d}\right)$ Absorption spectra of spectrum of PC (3DPAFIPN) $\left(8.0 \times 10^{-4} \mathrm{M}\right)$ with $\mathbf{1 a}\left(6.7 \times 10^{-2} \mathrm{M}\right)$ and $\mathbf{1 b}\left(6.7 \times 10^{-2} \mathrm{M}\right)$. 
a)

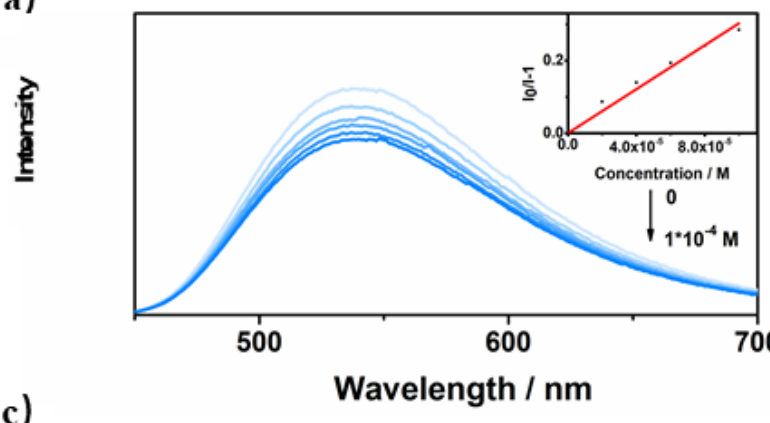

c)

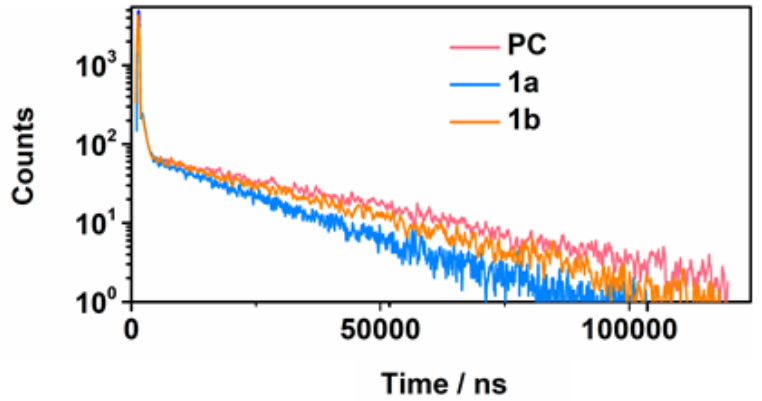

b)

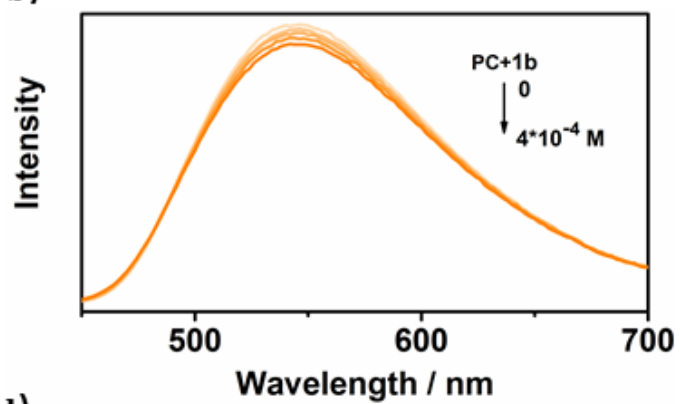

d)

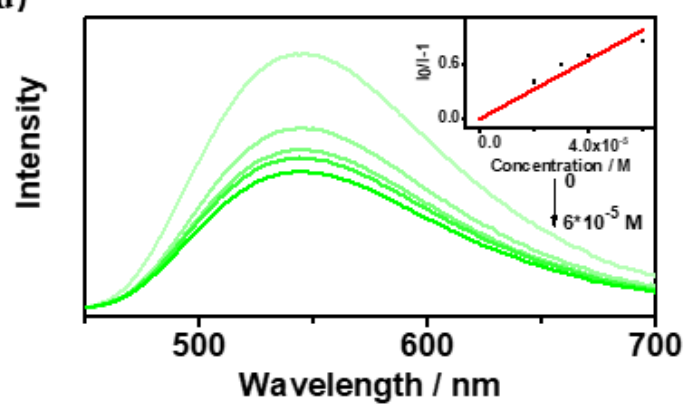

Figure S3. a) The luminescence spectrum of PC (3DPAFIPN) $\left(6.0 \times 10^{-5} \mathrm{M}\right)$ as a function of concentration of $\mathbf{1 a}$ in degassed $\mathrm{CH}_{3} \mathrm{CN}$ with excitation at $430 \mathrm{~nm}$, Quenching constant $k_{\text {et }}=$ $9.8 \times 10^{7} \mathrm{~s}^{-1} \mathrm{M}^{-1}$ for 1a. b) The luminescence spectrum of PC (3DPAFIPN) $\left(6.0 \times 10^{-5} \mathrm{M}\right)$ as a function of concentration of $\mathbf{1 b}$ in degassed $\mathrm{CH}_{3} \mathrm{CN}$ with excitation at $430 \mathrm{~nm}$; c) The luminescence decay of PC (3DPAFIPN) $\left(6.0 \times 10^{-5} \mathrm{M}\right)$ with $\mathbf{1 a}\left(5.0 \times 10^{-5} \mathrm{M}\right)$ and $\mathbf{1 b}\left(5.0 \times 10^{-5} \mathrm{M}\right)$ in $\mathrm{CH}_{3} \mathrm{CN}$; d) The luminescence spectrum of PC (3DPAFIPN) $\left(6.0 \times 10^{-5} \mathrm{M}\right)$ as a function of concentration of DABCO in degassed $\mathrm{CH}_{3} \mathrm{CN}$ with excitation at $430 \mathrm{~nm}$, Quenching constant $k_{\text {et }}$ $=5.3 \times 10^{8} \mathrm{~s}^{-1} \mathrm{M}^{-1}$ for DABCO. 

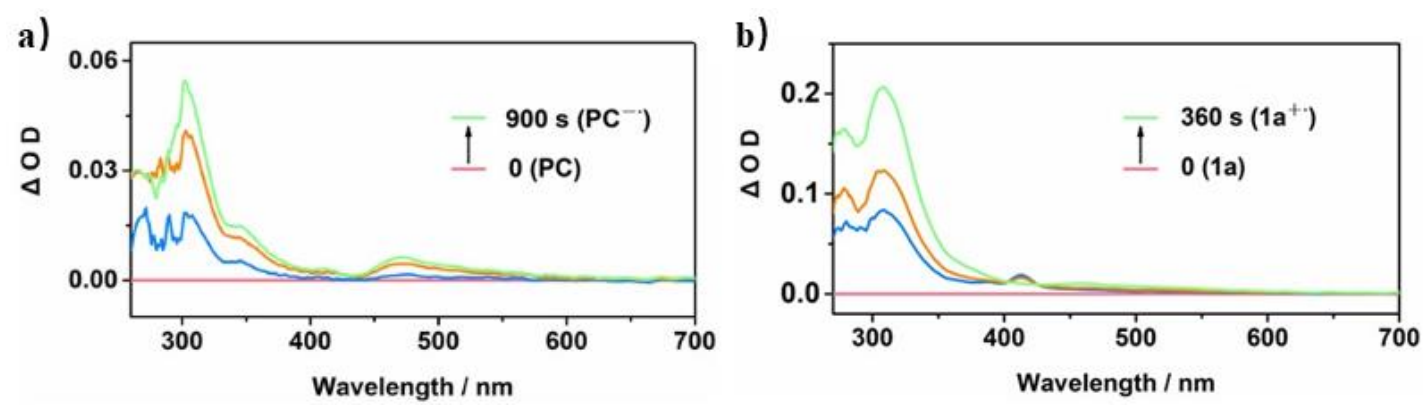

Figure S4. a) The spectroelectrochemical absorption spectrum of $\mathrm{PC}^{-\bullet}\left([3 \mathrm{DPAFIPN}]^{-*}\right)$ in $\mathrm{CH}_{3} \mathrm{CN}$ by reduction of PC (3DPAFIPN) $\left(3.0 \times 10^{-5} \mathrm{M}\right)$ at $-1.70 \mathrm{~V}$ voltage relative to NHE; $\left.b\right)$ the spectroelectrochemical absorption spectrum of $1 \mathbf{a}^{+\cdot}$ in $\mathrm{CH}_{3} \mathrm{CN}$ by oxidation of $1 \mathbf{a}\left(2.0 \times 10^{-4} \mathrm{M}\right)$ at $1.10 \mathrm{~V}$ voltage relative to NHE. 

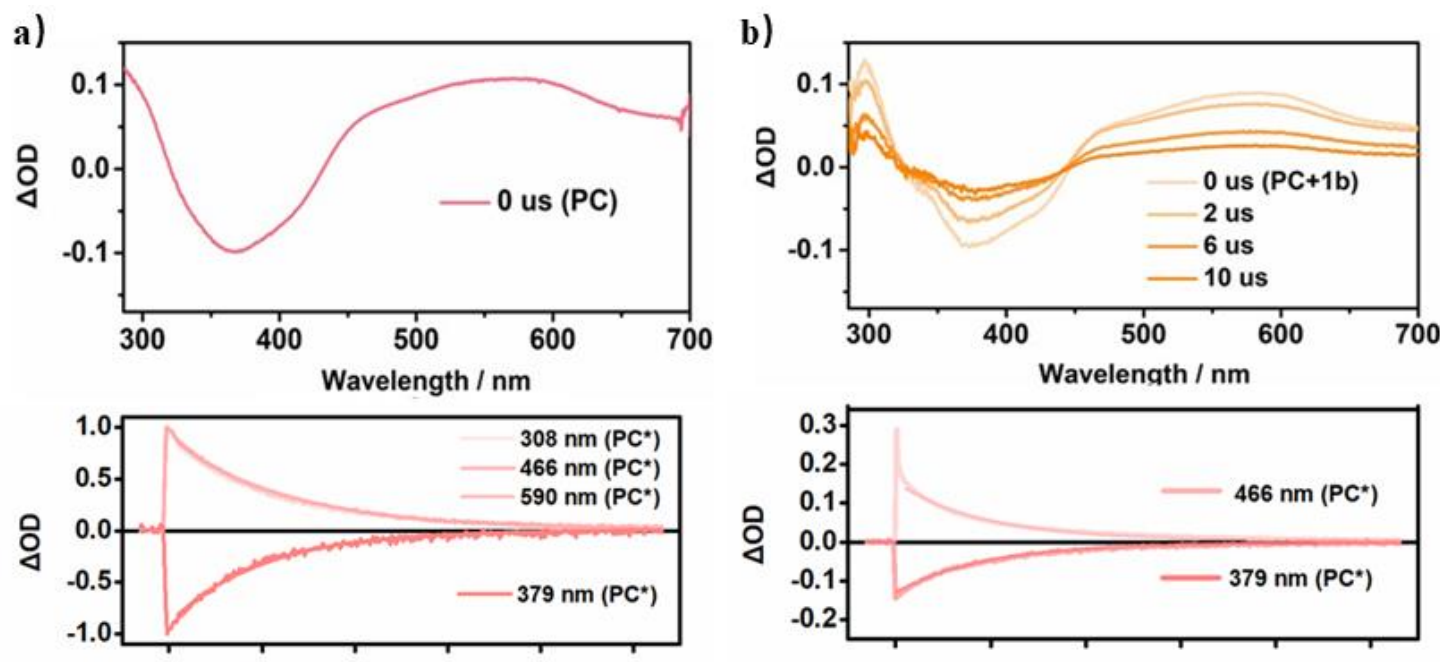

$\propto$

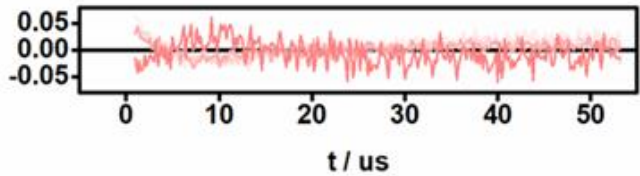

$\propto$

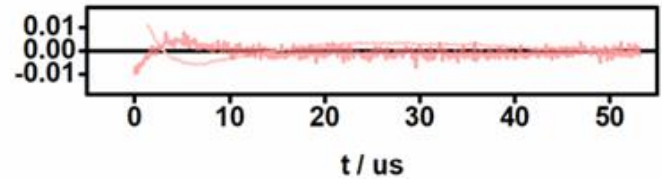

Figure S5. a) The transient absorption spectra of PC (3DPAFIPN) $\left(6 \times 10^{-5} \mathrm{M}\right)$; b) The transient absorption spectra of PC (3DPAFIPN) $\left(6 \times 10^{-5} \mathrm{M}\right)$ and PC (3DPAFIPN) $\left(6 \times 10^{-5} \mathrm{M}\right)$ with $\mathbf{1 b}$ $\left(1 \times 10^{-3} \mathrm{M}\right)$. 

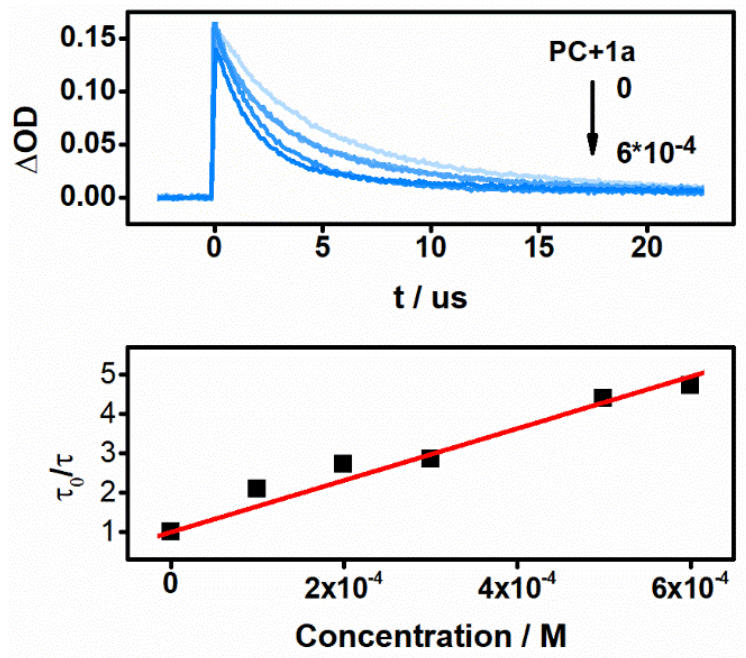

Figure S6. The transient absorption decay of PC (3DPAFIPN) $\left(6 \times 10^{-5} \mathrm{M}\right)$ with the different concentration of $\mathbf{1 a}$ (from 0 to $6 \times 10^{-4} \mathrm{M}$ ) at $590 \mathrm{~nm}$. According to the result, the electron transfer rate constant of $\mathbf{1 a}$ is $5.1 \times 10^{8} \mathrm{M}^{-1} \mathrm{~s}^{-1}$. 
$\underline{\text { Transient absorption analysis of the system with 3DPAFIPN, 1a and } \mathbf{1 b}}$

The photophyscial interaction between these components can be described in the following formulas:

1. PC (3DPAFIPN)+1a:

${ }^{3} P C^{*}+1 a \stackrel{k_{s q}}{\rightarrow} P C^{-\cdot}+1 a^{+^{-}} \quad$ Photoinduced single electron transfer

${ }^{3} P C^{*} \stackrel{\tau_{p}}{\rightarrow}{ }^{1} P C \quad$ Phosphorescence decay of the ${ }^{3} \mathrm{PC}^{*}\left({ }^{3}[3 \mathrm{DPAFIPN}]^{*}\right)$

$P C^{-\cdot} \stackrel{\tau_{-}}{\rightarrow} 1$ PC $\quad$ Decay of $\mathrm{PC}^{-\bullet}$ radical anion $\left([3 \mathrm{DPAFIPN}]^{-\bullet}\right)$

$1 a^{+\cdot} \stackrel{\tau_{a}}{\rightarrow} \mathbf{1 a} \quad$ Decay of $1 \mathbf{a}^{+\cdot}$ radical cation

2. PC (3DPAFIPN)+1a+1b:

${ }^{3} P C^{*}+1 a \stackrel{k_{s q}}{\longrightarrow} P C^{-\cdot}+1 a^{+^{-}} \quad$ Photoinduced single electron transfer

${ }^{3} P C^{*} \stackrel{\tau_{p}}{\rightarrow}{ }^{1} P C \quad$ Phosphorescence decay of ${ }^{3} \mathrm{PC}^{*}\left({ }^{3}[3 \mathrm{DPAFIPN}]^{*}\right)$

$P C^{-\cdot} \stackrel{\tau_{-}}{\rightarrow} 1$ PC $\quad$ Decay of $\mathrm{PC}^{-\bullet}$ radical anion $\left([3 \mathrm{DPAFIPN}]^{-\bullet}\right)$

$1 a^{+\cdot} \stackrel{\tau_{a}}{\rightarrow} \mathbf{1 a} \quad$ Decay of $1 \mathbf{a}^{+\bullet}$ radical cation

$P C^{-\cdot}+\mathbf{1} b \stackrel{k_{e t}}{\rightarrow} P C+\mathbf{1 b}^{-\cdot} \quad$ Electron transfer from $\mathrm{PC}^{-\cdot}$ radical anion $\left([3 \mathrm{DPAFIPN}]^{-\bullet}\right)$ to $\mathbf{1 b}$

$1 a^{+\cdot} \stackrel{\tau_{a}}{\rightarrow} \mathbf{1 a} \quad$ Decay of $1 \mathbf{a}^{+\cdot}$ radical cation

$\mathbf{1} \boldsymbol{b}^{-\cdot} \stackrel{\tau_{a}}{\rightarrow} \mathbf{1 b} \quad$ Decay of $\mathbf{1 b}^{-\cdot}$ radical anion

The transient absorption spectrum of PC (3DPAFIPN) consists 3 major excited state absorption (ESA) peaks and a ground state bleaching (GSB) peak (Fig. S4). The ESA peaks at $308 \mathrm{~nm}, 466$ $\mathrm{nm}$ and $590 \mathrm{~nm}$ are the $T_{1}$ to $T_{n}$ transition of 3DPAFIPN, while the GSB peak at $379 \mathrm{~nm}$ is due to the excitation of ground state PC. These transient peaks share the similar decay life times $(10.0 \mu \mathrm{s})$, which is the lifetime of the triplet 3DPAFIPN ( $\left.{ }^{3}[3 \mathrm{DPAFIPN}]^{*}\right)$.

In the transient absorption spectrum and decay of 3DPAFIPN and 1a solution (Fig. 1c-2), we found that $\mathrm{T}_{1}$ to $\mathrm{T}_{\mathrm{n}}$ transition decay of $\mathrm{PC}$ at $590 \mathrm{~nm}(4.1 \mu \mathrm{s})$ is much faster than pure 3DPAFIPN solution. The acceleration of the triplet decay indicates the photophysical interaction between ${ }^{3} \mathrm{PC}^{*}\left({ }^{3}[3 \mathrm{DPAFIPN}]^{*}\right)$ and 1a. The decay of ESA peak at $308 \mathrm{~nm}$ is longer than that in $590 \mathrm{~nm}$, indicating the formation of a new species. 
Spectroelectrochemical analysis of 3DPAFIPN and 1a (Fig. S3) shows that the radical cation of 1a $\left(\mathbf{1 a}^{+\bullet}\right)$ has much higher molar absorptivity at $308 \mathrm{~nm}$ than the $\mathrm{PC}^{-\cdot}$ radical anion ([3DPAFIPN $\left.]^{-}\right)$. The transient absorption signal at $308 \mathrm{~nm}$ after the decay of triplet 3DPAFIPN is then majorly contributed by the $\mathbf{1 a}^{+\bullet}$ cation radical. The decay lifetime $\mathbf{1 a}^{+\bullet}$ cation radical is then calculated to be $13.0 \mu$ s from a bi-exponential decay model. The result is in accordance with literature values. The longer lived the species at $466 \mathrm{~nm}$ up to $109.1 \mu \mathrm{s}$ is then assigned to the $\mathrm{PC}^{-}$radical anion.

\begin{tabular}{llllllll}
\hline$\lambda(\mathrm{nm})$ & $\tau_{1}$ & $B_{1}$ & $\tau_{2}$ & $B_{2}$ & $\tau_{3}$ & $B_{3}$ & $\chi^{2}$ \\
\hline 308 & 4.1 & $1.480 \times 10^{-2}$ & 13.3 & $8.584 \times 10^{-2}$ & - & - & 1.096 \\
379 & 4.1 & $6.259 \times 10^{-3}$ & 11.9 & $5.891 \times 10^{-2}$ & & & 0.740 \\
466 & 4.1 & $3.796 \times 10^{-3}$ & 13.0 & $1.406 \times 10^{-2}$ & 109.1 & $9.972 \times 10^{-3}$ & 1.249 \\
590 & 4.1 & $7.084 \times 10^{-2}$ & & & & & 1.253 \\
\hline
\end{tabular}

In the transient absorption spectroscopy of 3DPAFIPN and 1b in solution (Fig. S5), we found the same transient absorption behavior of 3DPAFIPN solution. We can then infer that there is no interaction between the excited states of ${ }^{3} \mathrm{PC}^{*}\left({ }^{3}[3 \mathrm{DPAFIPN}]^{*}\right)$ and the ground state $\mathbf{1 b}$.

In the transient absorption spectroscopy of 3DPAFIPN with 1a and $\mathbf{1 b}$ in solution (Fig. 1c-3), we found that ESA signal at $466 \mathrm{~nm}$ has a longer lifetime than the ESA signal at $590 \mathrm{~nm}$. It indicates the formation of $\mathrm{PC}^{-}$radical anion ([3DPAFIPN $]^{-}$) due to photo-induced energy transfer from ${ }^{3} \mathrm{PC}^{*}$ to 1a. However, the ESA lifetime at $466 \mathrm{~nm}$ is much shorter than the solution of PC and 1a. We can then infer an electron transfer from $\mathrm{PC}^{-}$to $\mathbf{1 b}$. By a bi-exponential decay fitting, we calculated that the decay lifetime of $\mathrm{PC}^{-\bullet}$ was quenched to $12.6 \mu \mathrm{s}$.

\begin{tabular}{llllll}
\hline$\lambda(\mathrm{nm})$ & $\tau_{1}$ & $B_{1}$ & $\tau_{2}$ & $B_{2}$ & $\chi^{2}$ \\
\hline 466 & 4.1 & $1.1 \times 10^{-2}$ & 12.6 & $2.0 \times 10^{-3}$ & 0.704 \\
\hline
\end{tabular}

The electron transfer rate constant can be calculated by the following equations:

$\frac{1}{\tau}-\frac{1}{\tau_{0}}=k_{1} C \quad$ (eq. 1$)$

where $\tau_{0}$ and $\tau$ are the lifetime of ${ }^{3} \mathrm{PC}^{*}\left({ }^{3}[3 \mathrm{DPAFIPN}]^{*}\right)$ without and with $1 \mathrm{a}, k_{l}$ is the electron transfer rate constant from, $\mathrm{C}$ is the concentration of 1a. Therefore, the electron transfer rate constant of 1a is $1.4 \times 10^{8} \mathrm{M}^{-1} \mathrm{~s}^{-1}$.

$\frac{1}{\tau}-\frac{1}{\tau_{0}}=k_{2} C \quad$ (eq. 2) 
where $\tau_{0}$ and $\tau$ are the lifetime of $\mathrm{PC}^{-\bullet}$ radical anion ([3DPAFIPN] $]^{-\bullet}$ ) without and with $\mathbf{1 b}, k_{2}$ is the electron transfer rate constant from, $\mathrm{C}$ is the concentration of $\mathbf{1 b}$. Therefore, the electron transfer rate constant of $\mathbf{1 b}$ is $7.0 \times 10^{7} \mathrm{M}^{-1} \mathrm{~s}^{-1}$. 
The radical formation

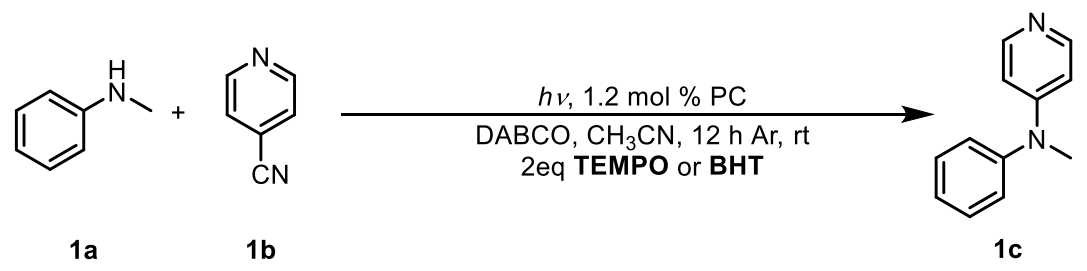

Scheme S1. The radical-trap experiment.

A $10 \mathrm{~mL}$ Pyrex tube equipped with a magnetic stir bar was charged with isonicotinonitrile (20.8 $\mathrm{mg}, 0.2 \mathrm{mmol})$, DABCO (22.4 mg, $0.2 \mathrm{mmol})$, PC (3DPAFIPN) (1.6 mg, $0.0024 \mathrm{mmol})$, TEMPO (0.4 mmol) or BHT $(0.4 \mathrm{mmol})$ in $\mathrm{CH}_{3} \mathrm{CN}(3 \mathrm{~mL})$. After the mixture was strictly deaerated, $N$-methylaniline ( $21.7 \mathrm{ul}, 0.2 \mathrm{mmol}$ ) was added into the mixture which was further irradiated by blue LEDs $(\lambda=450 \mathrm{~nm})$ for 12 hours at room temperature. When reaction was finished, the yields were decreased to 0 and $6 \%$ respectively, which determined by ${ }^{1} \mathrm{H}$ NMR using diphenylmethano as the internal standard.

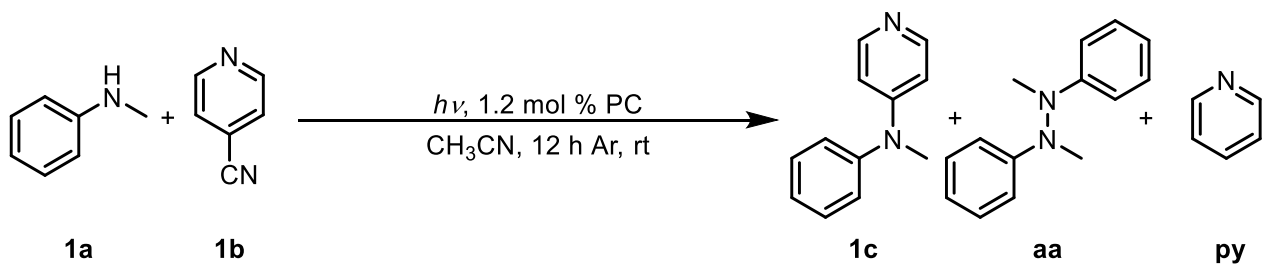

Scheme S2. The control experiment.

A $10 \mathrm{~mL}$ Pyrex tube equipped with a magnetic stir bar was charged with 1-isoquinolinecarbonitrile ( $30.8 \mathrm{mg}, 0.2 \mathrm{mmol}$ ), PC (3DPAFIPN) (1.6 mg, $0.0024 \mathrm{mmol})$, in $\mathrm{CH}_{3} \mathrm{CN}(3 \mathrm{~mL})$. After the mixture was strictly deaerated, $N$-methylaniline $(21.7 \mathrm{ul}, 0.2 \mathrm{mmol})$ was added into the mixture which was further irradiated by blue LEDs $(\lambda=450 \mathrm{~nm})$ for 12 hours at room temperature. When reaction was finished, the yield of $1 \mathbf{c}$ was decreased to $21 \%$ accompanied with trace aa and $\mathbf{p y}$, which was detected by ESI. All of yields were determined by ${ }^{1} \mathrm{H}$ NMR using diphenylmethano as the internal standard. The characterization data of aa was same as the reported elsewhere. 


\subsection{The role of DABCO}

The transient absorption spectra of the system with DABCO

a)
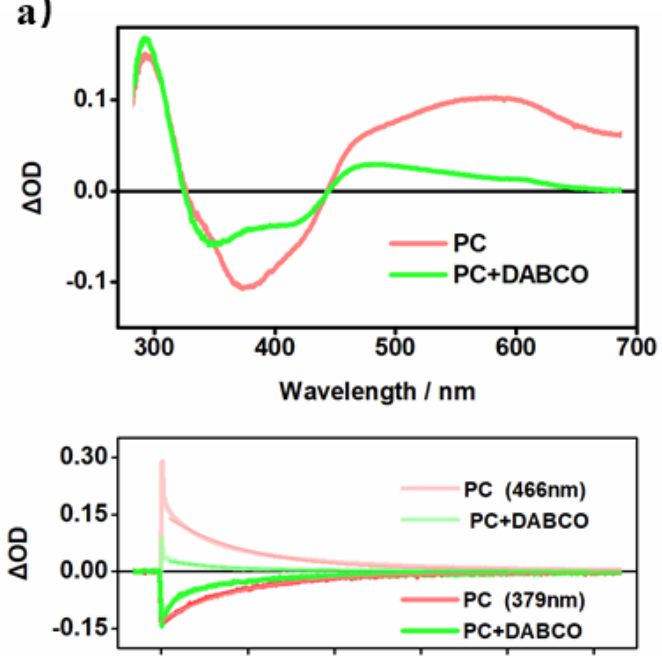

$\propto$

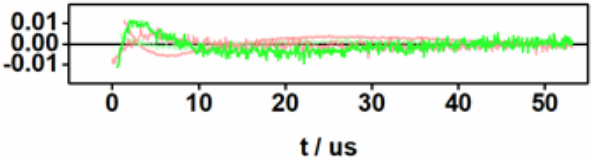

c)
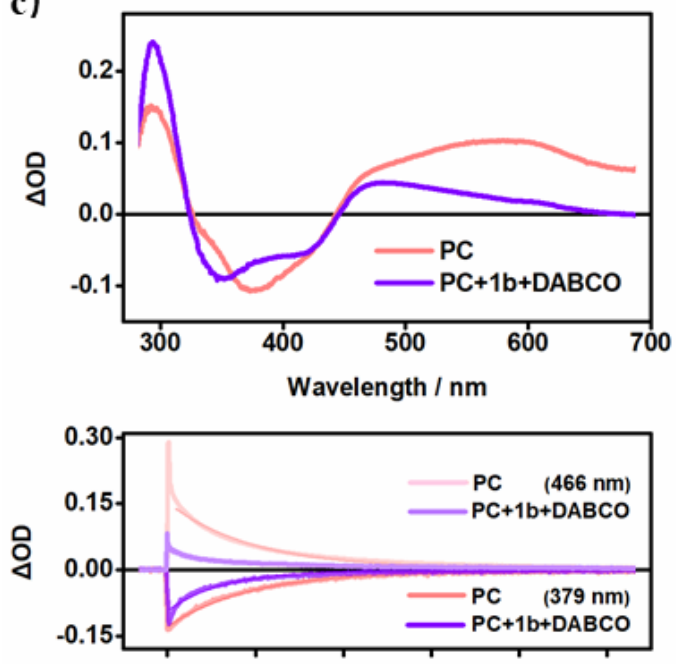

$\propto$

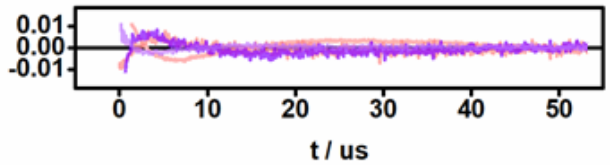

b)
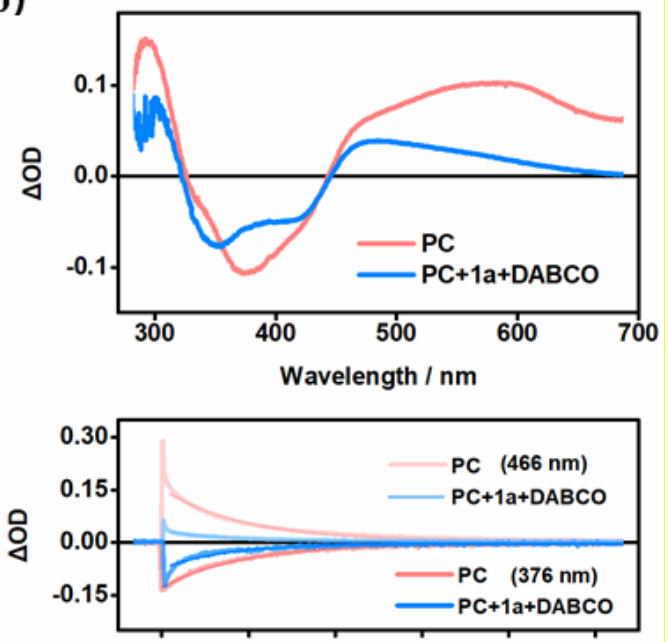

$\propto$

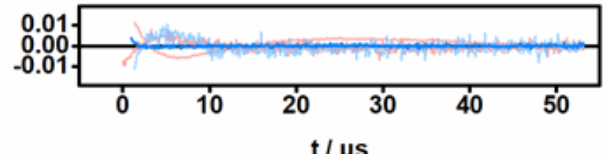

d)
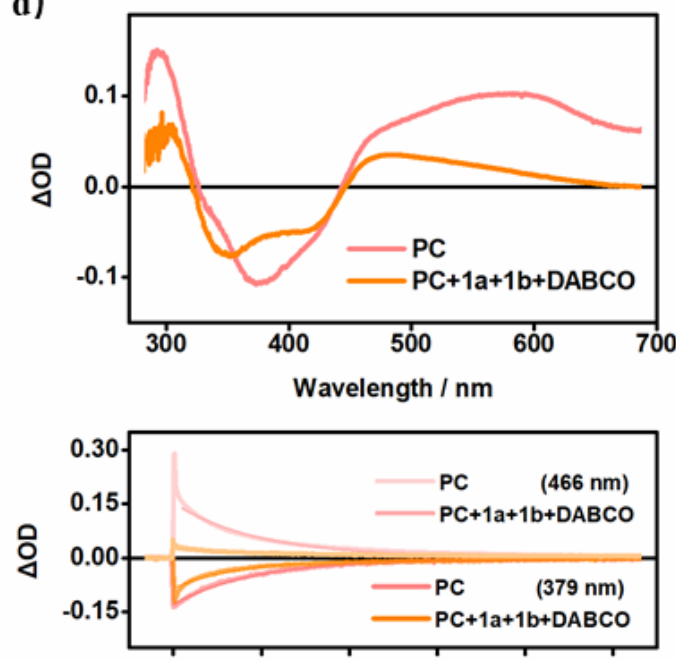

$\propto$

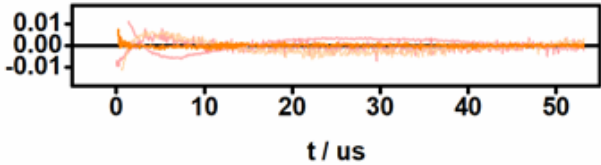

Figure S7. a) The transient absorption spectra of PC (3DPAFIPN) $\left(6 \times 10^{-5} \mathrm{M}\right)$ with DABCO $\left(1 \times 10^{-3} \mathrm{M}\right)$; b) The transient absorption spectra of PC (3DPAFIPN) $\left(6 \times 10^{-5} \mathrm{M}\right)$ with DABCO $\left(1 \times 10^{-3} \mathrm{M}\right)$ and $1 \mathrm{a}\left(1 \times 10^{-3} \mathrm{M}\right)$; c) The transient absorption spectra of PC (3DPAFIPN) $\left(6 \times 10^{-5}\right.$ M) with DABCO $\left(1 \times 10^{-3} \mathrm{M}\right)$ and $\mathbf{1 b}\left(1 \times 10^{-3} \mathrm{M}\right)$; d) The transient absorption spectra of PC (3DPAFIPN) $\left(6 \times 10^{-5} \mathrm{M}\right)$ with DABCO $\left(1 \times 10^{-3} \mathrm{M}\right), \mathbf{1 a}\left(1 \times 10^{-3} \mathrm{M}\right)$ and $\mathbf{1 b}\left(1 \times 10^{-3} \mathrm{M}\right)$. 
Transient absorption analysis of the system with DABCO.

After the addition of DABCO into this system, the photophyscial interaction between these components can be described in the following formulas:

1. PC (3DPAFIPN)+DABCO:

${ }^{3} \mathrm{PC}^{*}+\mathrm{DABCO} \stackrel{k_{s q}}{\rightarrow} \mathrm{PC}^{-\cdot}+D A B C \mathrm{O}^{+\cdot} \quad$ Photoinduced single electron transfer

${ }^{3} P C^{*} \stackrel{\tau_{p}}{\rightarrow}{ }^{1} P C \quad$ Phosphorescence decay of the ${ }^{3} \mathrm{PC}^{*}\left({ }^{3}[3 \mathrm{DPAFIPN}]^{*}\right)$

$P C^{-\cdot} \stackrel{\tau_{-}}{\rightarrow} P C \quad$ Decay of $\mathrm{PC}^{-\bullet}$ radical anion $\left([3 \mathrm{DPAFIPN}]^{-\bullet}\right)$

$D A B C O^{+\cdot} \stackrel{\tau_{a}}{\rightarrow} \mathbf{1 a} \quad$ Decay of $D A B C O^{+\cdot}$ radical cation

2. PC (3DPAFIPN)+DABCO+1b:

${ }^{3} \mathrm{PC}^{*}+\mathrm{DABCO} \stackrel{k_{s q}}{\rightarrow} \mathrm{PC}^{-\cdot}+D A B C \mathrm{O}^{+\cdot} \quad$ Photoinduced single electron transfer

${ }^{3} P C^{*} \stackrel{\tau_{p}}{\rightarrow}{ }^{1} P C \quad$ Phosphorescence decay of ${ }^{3} \mathrm{PC}^{*}\left({ }^{3}[3 \mathrm{DPAFIPN}]^{*}\right)$

$P C^{-\cdot}{\stackrel{\tau_{-}}{\rightarrow}}^{1} P C \quad$ Decay of $\mathrm{PC}^{-\bullet}$ radical anion $\left([3 \mathrm{DPAFIPN}]^{-\bullet}\right)$

$D A B C O^{+\cdot} \stackrel{\tau_{a}}{\rightarrow} D A B C O \quad$ Decay of $D A B C O^{+\bullet}$ radical cation

$P C^{-\cdot}+\mathbf{1} b \stackrel{k_{e t}}{\rightarrow} P C+\mathbf{1 b}^{-\cdot} \quad$ Electron transfer from $\mathrm{PC}^{-\bullet}$ radical anion $\left([3 \mathrm{DPAFIPN}]^{-\bullet}\right)$ to $\mathbf{1 b}$

$D A B C O^{+\cdot} \stackrel{\tau_{a}}{\rightarrow} D A B C O \quad$ Decay of $D A B C O^{+\bullet}$ radical cation

$\mathbf{1} \boldsymbol{b}^{-\cdot} \stackrel{\tau_{a}}{\rightarrow} \mathbf{1 b} \quad$ Decay of $\mathbf{1 b}^{-\cdot}$ radical anion

3. PC (3DPAFIPN)+DABCO+1a+1b:

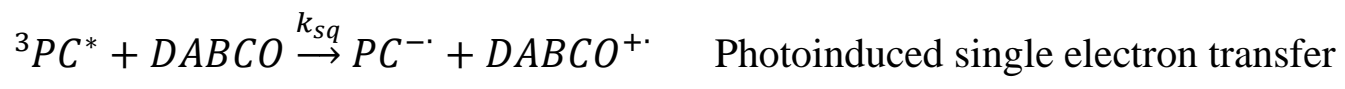

${ }^{3} P C^{*}+1 a \stackrel{k_{s q}}{\rightarrow} P C^{-\cdot}+1 a^{+\cdot} \quad$ Photoinduced single electron transfer

$D A B C O^{+\cdot}+1 a \stackrel{\tau_{r}}{\rightarrow} D A B C O+1 a^{+\cdot} \quad$ Relay of $D A B C O^{+\bullet}$ radical cation

${ }^{3} P C^{*} \stackrel{\tau_{p}}{\rightarrow}{ }^{1} P C \quad$ Phosphorescence decay of ${ }^{3} \mathrm{PC}^{*}\left({ }^{3}[3 \mathrm{DPAFIPN}]^{*}\right)$

$P C^{-\cdot} \stackrel{\tau_{-}}{\rightarrow} 1$ PC $\quad$ Decay of $\mathrm{PC}^{-\bullet}$ radical anion $\left([3 \mathrm{DPAFIPN}]^{-\bullet}\right)$

$D A B C O^{+\cdot} \stackrel{\tau_{a}}{\rightarrow} D A B C O \quad$ Decay of $D A B C O^{+\bullet}$ radical cation 
$1 a^{+\cdot} \stackrel{\tau_{a}}{\rightarrow} \mathbf{1 a} \quad$ Decay of $1 \mathbf{a}^{+\cdot}$ radical cation

$P C^{-\cdot}+\mathbf{1} b \stackrel{k_{e t}}{\rightarrow} 11 P C+\mathbf{1} b^{-\cdot} \quad$ Electron transfer from $\mathrm{PC}^{-\cdot}$ radical anion $\left([3 \mathrm{DPAFIPN}]^{-\bullet}\right)$ to $\mathbf{1 b}$.

$D A B C O^{++} \stackrel{\tau_{a}}{\rightarrow} D A B C O \quad$ Decay of $D A B C O^{+\cdot}$ radical cation

$\mathbf{1} \boldsymbol{b}^{-\cdot} \stackrel{\tau_{a}}{\rightarrow} \mathbf{1 b} \quad$ Decay of $\mathbf{1 b ^ { - \cdot }}$ radical anion

To simplify the system, we used the same method to analyze the transient absorption spectroscopy of DABCO as the above. By a bi-exponential decay fitting at $466 \mathrm{~nm}$, we calculated that the decay lifetime of $\mathrm{PC}^{-}$was $107 \mu \mathrm{s}, 62.1 \mu \mathrm{s}, 87.4 \mu \mathrm{s}$ respectively with the addition of DABCO into the solution containing $\mathrm{PC}, \mathrm{PC}+\mathbf{1 b}$ or $\mathrm{PC}+\mathbf{1 a}+\mathbf{1 b}$.

\begin{tabular}{lllllll}
\hline Entry & $\lambda(\mathrm{nm})$ & $\tau_{1}$ & $B_{1}$ & $\tau_{2}$ & $B_{2}$ & $\chi^{2}$ \\
\hline PC+DABCO & 466 & 6.16 & $2.7 \times 10^{-2}$ & 107 & $5.0 \times 10^{-3}$ & 0.460 \\
& & & & & \\
PC+DABCO+1b & 466 & 6.13 & $3.2 \times 10^{-2}$ & 62.1 & $1.1 \times 10^{-2}$ & 0.417 \\
PC+DABCO+1a+1b & 466 & 6.82 & $1.9 \times 10^{-2}$ & 87.4 & $1.3 \times 10^{-2}$ & 0.624 \\
\hline
\end{tabular}

To figure out the role of DABCO in this radical-radical cross-coupling reaction, the laser flash photolysis measurements of the solutions including $\mathrm{PC}+\mathrm{DACBCO}, \mathrm{PC}+\mathbf{1 a}+\mathrm{DACBCO}$, $\mathrm{PC}+\mathbf{1 b}+\mathrm{DACBCO}$ and $\mathrm{PC}+\mathbf{1 a}+\mathbf{1 b}+\mathrm{DACBCO}$ were also carried out. As shown in Figure S7a, the single electron transfer from DABCO to the excited ${ }^{3} \mathrm{PC}^{*}$ provided $\mathrm{PC}^{-\bullet}$ with the lifetime $107 \mu \mathrm{s}$, similar to that $(109.1 \mu \mathrm{s})$ in the system of PC+1a. With the addition of $\mathbf{1 b}$ into the solution of $\mathrm{PC}+\mathrm{DACBCO}$ (Figure S7b, S7c), the lifetime of $\mathrm{PC}^{-\bullet}$ was decreased to $62.1 \mu \mathrm{s}$, indicating the singlet electron transfer from $\mathrm{PC}^{-} \bullet$ to $\mathbf{1 b}$. When $\mathbf{1 a}$ was added into the solution including $\mathrm{PC}+\mathrm{DABCO}+\mathbf{1 b}$, the lifetime of $\mathrm{PC}^{-}{ }^{\bullet}$ was prolonged from $62.1 \mu$ s to $87.4 \mu \mathrm{s}$. As compared with the lifetime of $\mathrm{PC}^{-\bullet}(12.6 \mu \mathrm{s})$ in the solution with $\mathrm{PC}+\mathbf{1 a}+\mathbf{1 b}$ mentioned in Figure S6, the presence of DABCO prolonged the lifetime of $\mathrm{PC}^{-\bullet}$ to $87.4 \mu$ s (Figure S7d), which was attributed to the relay characteristic of DABCO suppressing charge recombination that is helpful for improving the efficiency of singlet electron transfer C-N formation. 


\subsection{The reactivity of heteroaryl halide}

Given that the abundant source and wide application of aryl halides, a series of heteroaryl halides were examined their compatibility in our system. As shown in Scheme S3, para-halogenated pyridine $\left(\mathrm{Cl}, \mathrm{Br}\right.$ and I) and 1-bromoisoquinoline failed to couple with $\mathbf{1}^{\mathbf{a}^{\bullet}}$, but to provide pyridine or isoquinoline as the product instead.

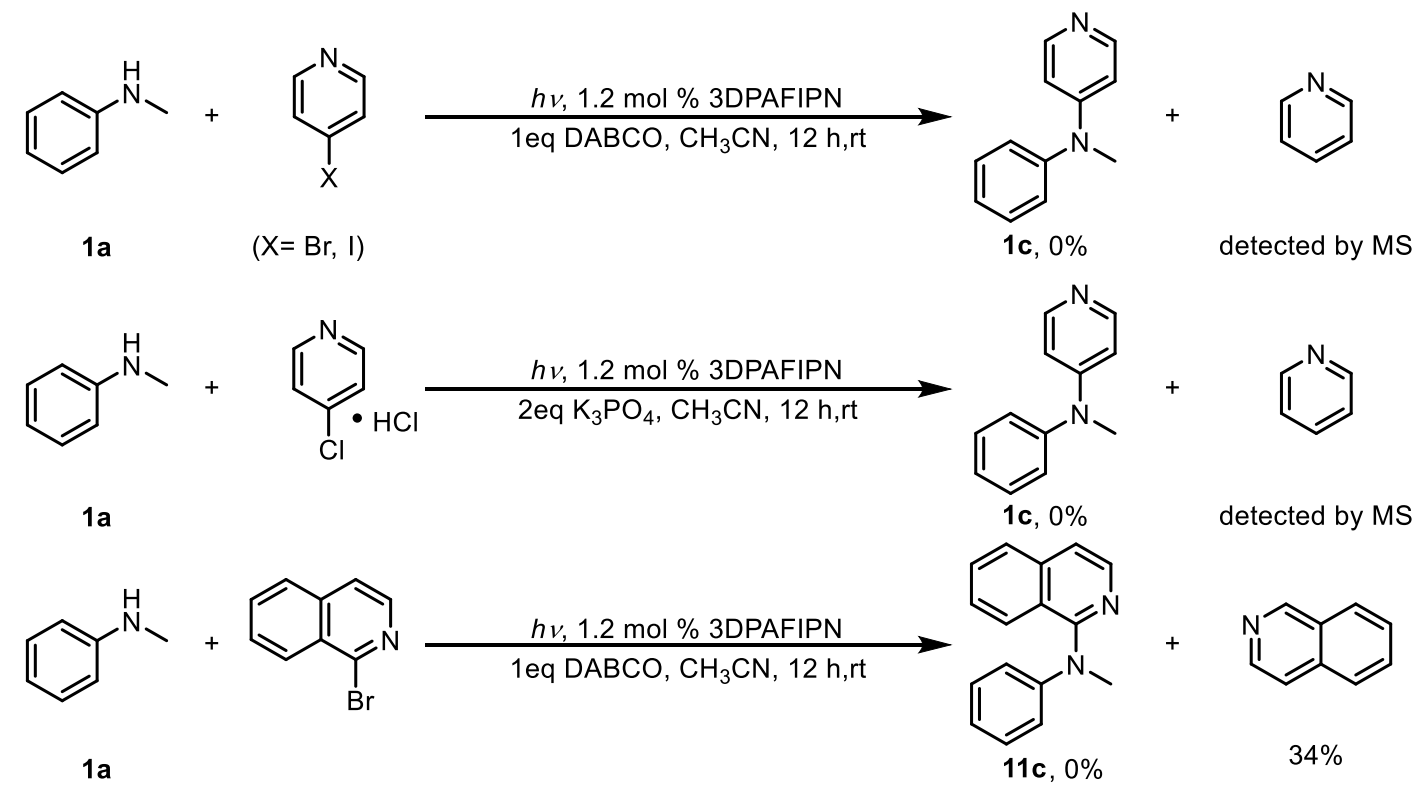

Scheme S3. Photocatalysis for arylamine formation with different heteroaryl halide.

To understand the reason, we selected 4-bromopyridine as a model to investigate the radical formation by flash photolysis (Figure 1). When 4-bromopyridine was added into the system of $\mathrm{PC}$ and 1a, the lifetime of $\mathrm{PC}^{-\bullet}\left([3 \mathrm{DPAFIPN}]^{-\bullet}\right)$ at $466 \mathrm{~nm}$ was quenched from $109.1 \mu$ s to 67.9 $\mu \mathrm{s}$, indicating the singlet electron transfer (SET) from $\mathrm{PC}^{-\bullet}$ to 4 -bromopyridine is feasible. However, 4-cyanopyridine $\mathbf{1 b}$ in the manuscript quenched the lifetime of $\mathrm{PC}^{-\bullet}\left([3 \mathrm{DPAFIPN}]^{\bullet}\right.$ ) at $466 \mathrm{~nm}$ from $109.1 \mu$ s to $12.6 \mu$ s. Obviously, the rate constant of radical formation of 4-bromopyridine $\left(5.5 \times 10^{6} \mathrm{M}^{-1} \mathrm{~s}^{-1}\right)$ from singlet electron transfer event was much slower than that of $\mathbf{1 b}\left(7.0 \times 10^{7} \mathrm{M}^{-1} \mathrm{~s}^{-1}\right)$, and even two-order magnitude slower than the singlet electron transfer from ${ }^{3} \mathrm{PC} *$ to $1 \mathbf{a}\left(5.1 \times 10^{8} \mathrm{M}^{-1} \mathrm{~s}^{-1}\right)$ to produce $\mathbf{1 a}^{+\bullet}$. Therefore, the large rate differences on the radical generation of 4-bromopyridine and 1a led to no reactivity observed in the following cross-coupling reaction. 

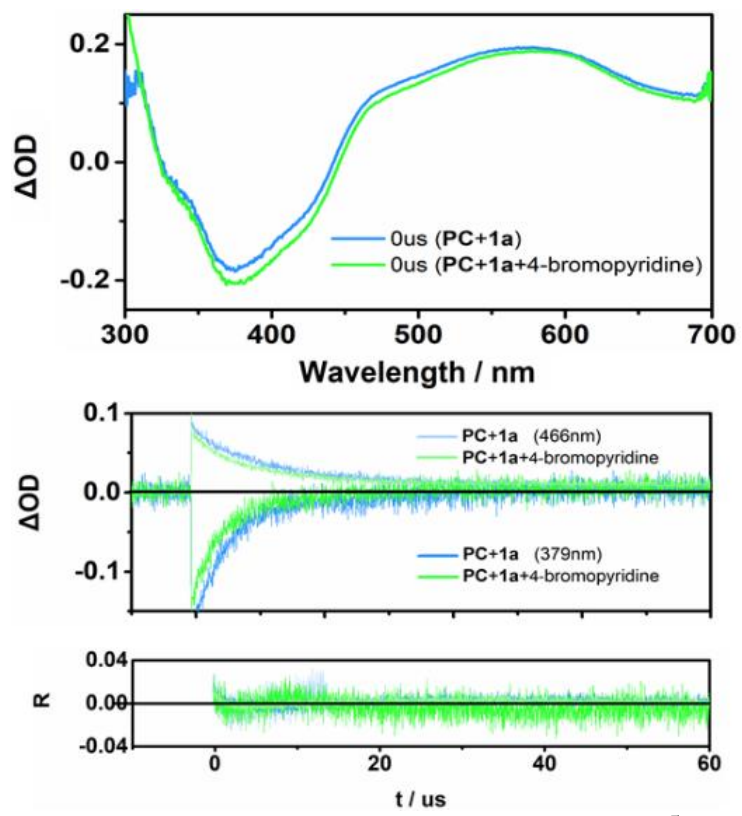

Figure S8. The transient absorption spectra of 3DPAFIPN $\left(6 \times 10^{-5} \mathrm{M}\right)$ and $\mathbf{1 a}\left(1 \times 10^{-3} \mathrm{M}\right)$ with or without 4-bromopyridine $\left(1 \times 10^{-3} \mathrm{M}\right)$.

\section{$\underline{\text { Transient absorption analysis }}$}

Replacing 1b with 4-bromopyridine, we used the same method to analyze the transient absorption spectroscopy as the above. By a bi-exponential decay fitting at $466 \mathrm{~nm}$, we calculated that the decay lifetime of $\mathrm{PC}^{-\bullet}$ was $67.9 \mu$ s with the addition of 4-bromopyridine into the solution containing $\mathrm{PC}+\mathbf{1 a}$. Furthermore, the electron transfer rate constant of 4-bromopyridine or 2-cyanopyridine with $\mathrm{PC}^{-\bullet}$ is $5.5 \times 10^{6} \mathrm{M}^{-1} \mathrm{~s}^{-1}$.

\begin{tabular}{lllllll}
\hline Entry & $\lambda(\mathrm{nm})$ & $\tau_{1}$ & $B_{1}$ & $\tau_{2}$ & $B_{2}$ & $\chi^{2}$ \\
\hline PC+1a+4-bromopyridine & 466 & 4.5 & $5.4 \times 10^{-2}$ & 67.9 & $1.2 \times 10^{-2}$ & 0.706 \\
\hline
\end{tabular}




\subsection{The reactivity of 3-cyanopyridine and 2-cyanopyridine}

To exclude the possibility of reaction in Minisci-type process, we carried out the control experiment to examine the reactivity of 3-cyanopyridine and 2-cyanopyridine under the standard condition (Scheme S4). It was found that 1a could not work with 3-cyanopyridine under the standard condition, excluding the Minisci-type reaction process; but poor reactivity of 1a with 2-cyanopyridine detected by GC-MS.

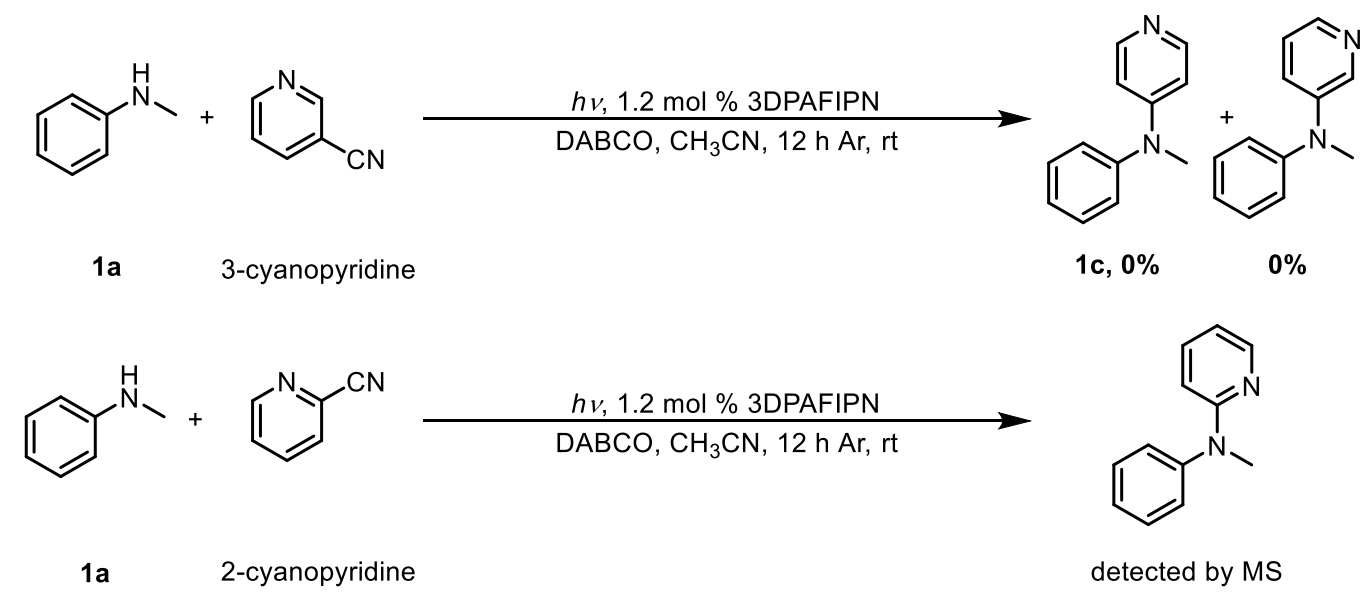

Scheme S4. The photocatalysis for arylammine formation with different heteroarylnitriles.

To shed more light on the poor reactivity of 2-cyanopyridine, CV experiments were carried out with 3-cyanopyridine as comparison. For 2-cyanopyridine, a new reductive peak was detected after $\mathbf{1 a}$ was added (Figure S9a), indicating that $\mathbf{1} \mathbf{a}^{+\bullet}$ could activate 2-cyanopyridine to lower its relative reductive potential from $-2.04 \mathrm{~V}$ to $-1.13 \mathrm{~V}$ (vs SCE). The decrease of reductive potential allowed the singlet electron transfer from $\mathrm{PC}^{-\bullet}\left[E_{1 / 2}\left(\mathrm{PC} / \mathrm{PC}^{-\bullet}\right)=-1.59 \mathrm{~V}\right.$ vs SCE $]$ to the activated 2-cyanopyridine. For 3-cyanopyridine, no obvious change in the CV spectra of $1 \mathrm{a}$ and 3 -cyanopyridine indicated a weak activation of 3-cyanopyridine $\left(E_{1 / 2}{ }^{\mathrm{red}}=-2.11 \mathrm{~V} \mathrm{SCE}\right)$ by $\mathbf{1 \mathbf { a } ^ { + }}$ (Figure S9b).
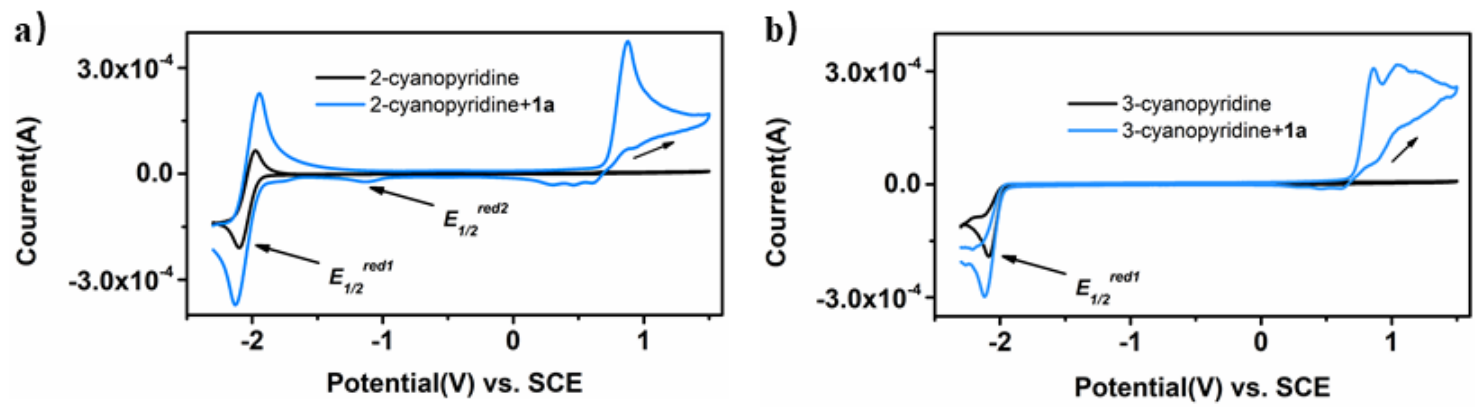

Figure S9. a) The CV spectra of 2-cyanopyridine $\left(5.0 \times 10^{-3} \mathrm{M}\right)$ and $\mathrm{NBu}_{4} \mathrm{PF}_{6}\left(1.0 \times 10^{-1} \mathrm{M}\right)$ in the absence and presence of $1 \mathbf{a}\left(5.0 \times 10^{-3} \mathrm{M}\right)$ in degassed $\mathrm{CH}_{3} \mathrm{CN}, E_{1 / 2}{ }^{\text {red1 }}=-2.04 \mathrm{~V} \mathrm{SCE}, E_{1 / 2}{ }^{\text {red2 }}$ $=-1.13 \mathrm{~V} \mathrm{SCE}$; $\mathrm{b})$ The CV spectra of 3-cyanopyridine $\left(5.0 \times 10^{-3} \mathrm{M}\right)$ and $\mathrm{NBu}_{4} \mathrm{PF}_{6}\left(1.0 \times 10^{-1} \mathrm{M}\right)$ in the absence and presence of $1 \mathrm{a}\left(5.0 \times 10^{-3} \mathrm{M}\right)$ in degassed $\mathrm{CH}_{3} \mathrm{CN}, E_{1 / 2}{ }^{\text {red1 }}=-2.11 \mathrm{~V} \mathrm{SCE}$. 
Moreover, the flash photolysis showed that 2-cyanopyridine could quench $\mathrm{PC}^{-\bullet}\left([3 \mathrm{DPAFIPN}]^{-\bullet}\right)$ at $466 \mathrm{~nm}$ from $109.1 \mu$ s to $79.7 \mu$ s with a rate constant of $3.4 \times 10^{6} \mathrm{M}^{-1} \mathrm{~s}^{-1}$, while 3-cyanopyridine had no any alternation on the lifetime of $\mathrm{PC}^{-\bullet}\left([3 \mathrm{DPAFIPN}]^{-\bullet}\right)$ (Figure S10), suggesting the feasibility of the singlet electron transfer from $\mathrm{PC}^{-\bullet}$ to 2-cyanopyridine rather than 3-cyanopyridine. However, 4-cyanopyridine $\mathbf{1 b}$ quenched the $\mathrm{PC}^{-\bullet}\left([3 \mathrm{DPAFIPN}]^{-\bullet}\right)$ at $466 \mathrm{~nm}$ from $109.1 \mu$ s to $12.6 \mu$ s with a rate constant of $7.0 \times 10^{7} \mathrm{M}^{-1} \mathrm{~s}^{-1}$, which is much faster than the singlet-electron-transfer rate of 2-cyanopyridine $\left(3.4 \times 10^{6} \mathrm{M}^{-1} \mathrm{~s}^{-1}\right)$. More significantly, the two-order magnitude slower of the singlet electron transfer from $\mathrm{PC}^{-\bullet}\left([3 \mathrm{DPAFIPN}]^{-\bullet}\right)$ to 2-cyanopyridine $\left(3.4 \times 10^{6} \mathrm{M}^{-1} \mathrm{~s}^{-1}\right)$ than that from ${ }^{3} \mathrm{PC} *$ to $\mathbf{1 a}\left(5.1 \times 10^{8} \mathrm{M}^{-1} \mathrm{~s}^{-1}\right)$ to produce $\mathbf{1 a ^ { + }}$ was believed responsible for the poor reactivity of 2-cyanopyridine.

a)
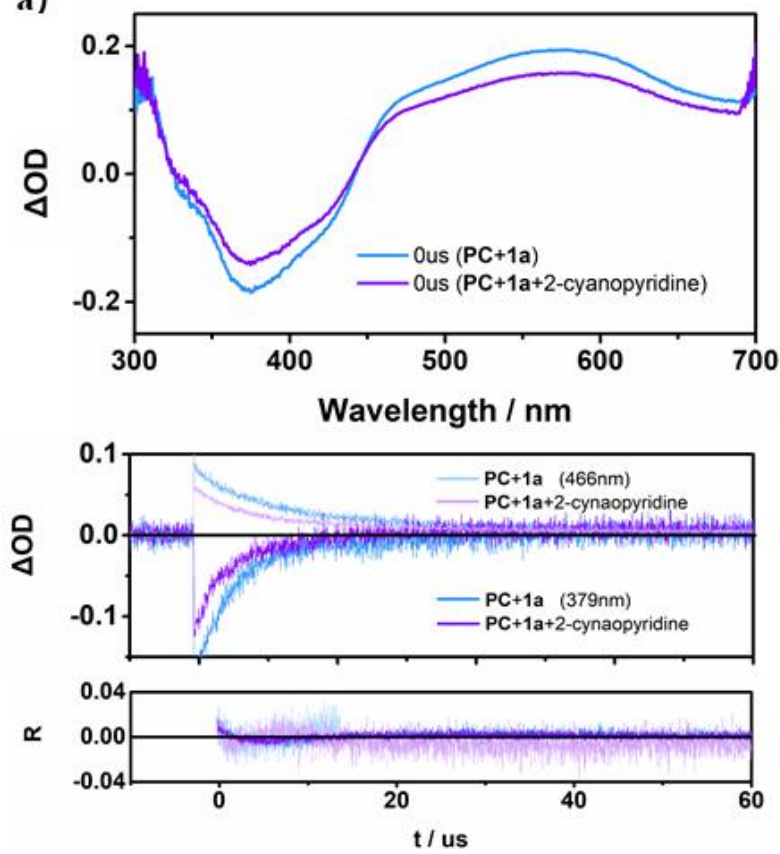

b)
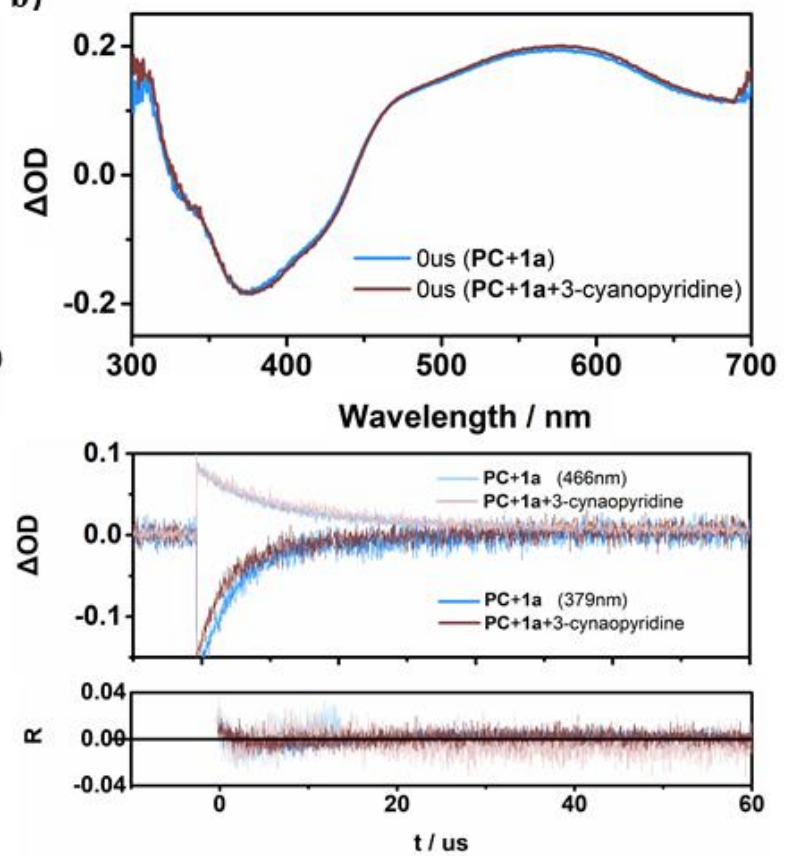

Figure S10. a) The transient absorption spectra of 3 DPAFIPN $\left(6 \times 10^{-5} \mathrm{M}\right)$ and $1 \mathbf{a}\left(1 \times 10^{-3} \mathrm{M}\right)$ with or without 2-cyanopyridine $\left(1 \times 10^{-3} \mathrm{M}\right)$; b) The transient absorption spectra of 3DPAFIPN $\left(6 \times 10^{-5} \mathrm{M}\right)$ and $1 \mathbf{a}\left(1 \times 10^{-3} \mathrm{M}\right)$ with or without 3-cyanopyridine $\left(1 \times 10^{-3} \mathrm{M}\right)$.

$\underline{\text { Transient absorption analysis }}$

Replacing 1b with 2-cyanopyridine, we used the same method to analyze the transient absorption spectroscopy as the above. By a bi-exponential decay fitting at $466 \mathrm{~nm}$, we calculated that the decay lifetime of $\mathrm{PC}^{-\bullet}$ was $79.7 \mu$ s with the addition of 2-cyanopyridine into the solution containing $\mathrm{PC}+\mathbf{1 a}$. Furthermore, the electron transfer rate constant of 2-cyanopyridine with $\mathrm{PC}^{-}$ was determined as $3.4 \times 10^{6} \mathrm{M}^{-1} \mathrm{~s}^{-1}$.

\begin{tabular}{lllllll}
\hline Entry & $\lambda(\mathrm{nm})$ & $\tau_{1}$ & $B_{1}$ & $\tau_{2}$ & $B_{2}$ & $\chi^{2}$ \\
\hline PC+1a+2-cyanopyridine & 466 & 4.4 & $3.7 \times 10^{-2}$ & 79.7 & $9.1 \times 10^{-3}$ & 0.702 \\
\hline
\end{tabular}




\subsection{The scope of photocatalysts}

Although their redox potential were matched for this radical-radical cross-coupling reaction, 4CzIPN, Eosin Y and Rh6G showed no product formation as shown in Table S1. To figure out the no reactivities of these photocatalysis, the flash photolysis investigations were also undertaken. The signals of Rh6G in the transient absorption spectra were too weak to obtain any useful information, and only the transient absorption spectra of Eosin Y and 4CzIPN were provided (Figure S11, S12).

Eosin Y displayed strong bleach of the ground state absorption (GSB) at approximately $515 \mathrm{~nm}$ and the excited state absorption assigned to the triplet excited state ${ }^{3}$ Eosin $\mathrm{Y}^{*}$ at $570 \mathrm{~nm}$ after a laser excitation by $530 \mathrm{~nm}$ light (Figure S11a). When 1a was introduced into the solution of Eosin $\mathrm{Y}$, the new absorption bands at $425 \mathrm{~nm}$ appeared at the expense of the ${ }^{3}$ Eosin $\mathrm{Y}^{*}$ absorption at $570 \mathrm{~nm}$, which was assigned to Eosin $\mathrm{Y}^{-\bullet}$. However, the introduction of $\mathbf{1 b}$ into the solution with Eosin $\mathrm{Y}$ and 1a resulted in no change of the absorption of Eosin $\mathrm{Y}^{-\bullet}$ (Figure S11b). These results indicated the singlet electron transfer from ${ }^{3}$ Eosin $Y^{*}$ to $1 \mathbf{a}$ is feasible, but not for Eosin $\mathrm{Y}^{-\bullet}$ to $\mathbf{1 b}$ in spite of in the suitable potentials $\left(-1.06 \mathrm{~V}\right.$ vs SCE for Eosin $\mathrm{Y}^{-\bullet}$ and $-0.87 \mathrm{~V}$ vs SCE for $\mathbf{1 b}$ in the presence of $\mathbf{1} \mathbf{a}^{+\bullet}$ ).

The situation of $4 \mathrm{CzIPN}$ was same as that of Eosin Y. When 1a was introduced into the solution of $4 \mathrm{CzIPN}$, the new absorption bands at $465 \mathrm{~nm}$ appeared (Figure S12a), which was assigned to $4 \mathrm{CzIPN}^{-\bullet}$. However, there was no change of the absorption of $4 \mathrm{CzIPN}^{-\bullet}$ with the addition of $\mathbf{1 b}$ into the solution of $4 \mathrm{CzIPN}$ and 1 a (Figure S12b), which suggested that ${ }^{3} 4 \mathrm{CzIPN} *$ could efficiently oxidize $1 \mathbf{a}$ to produce $\mathbf{1 a}^{+\bullet}$, while $4 \mathrm{CzIPN}^{-\bullet}$ failed to reduce $\mathbf{1 b}$ to provide $\mathbf{1 b}^{-\bullet}$ for subsequent reaction.
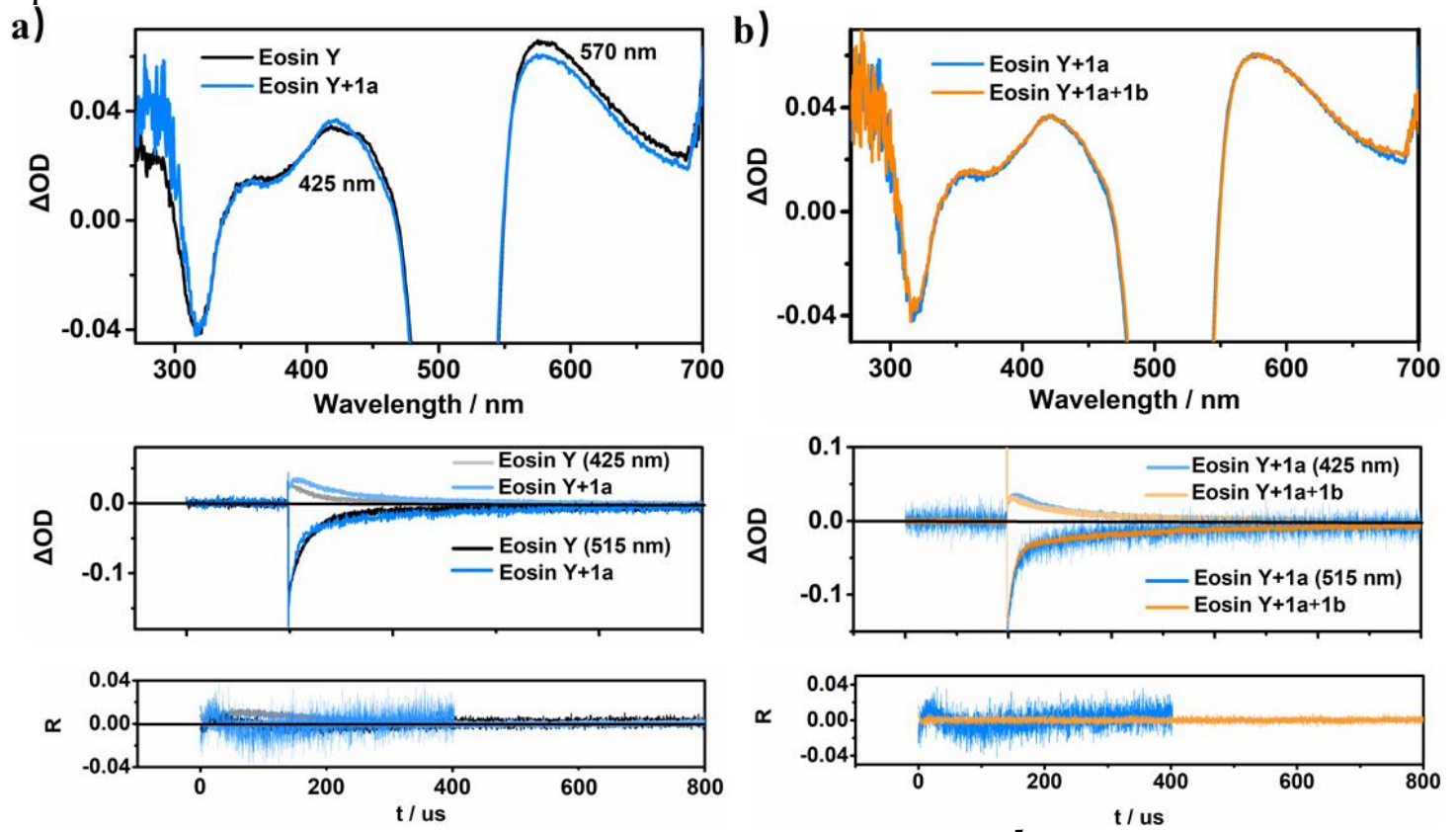

Figure S11. a) The transient absorption spectra of EosinY $\left(5 \times 10^{-5} \mathrm{M}\right)$ with or without $1 \mathbf{a}$ $\left(1 \times 10^{-3} \mathrm{M}\right)$; b) The transient absorption spectra of EosinY $\left(5 \times 10^{-5} \mathrm{M}\right)$ and $1 \mathbf{a}\left(1 \times 10^{-3} \mathrm{M}\right)$ with or without $\mathbf{1 b}\left(1 \times 10^{-3} \mathrm{M}\right)$. 

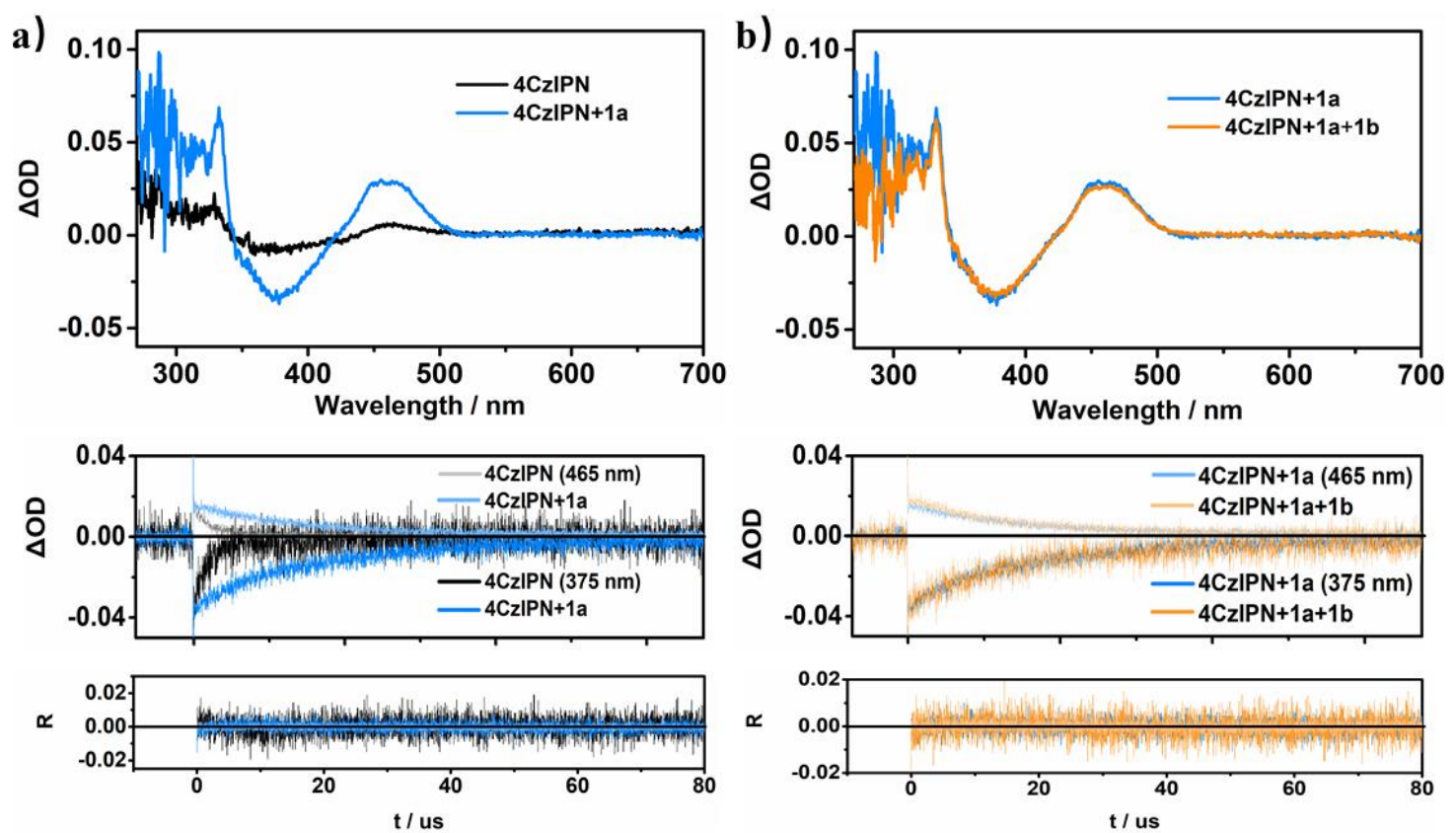

Figure S12. a) The transient absorption spectra of $4 \mathrm{CzIPN}\left(5 \times 10^{-5} \mathrm{M}\right)$ with or without 1a $\left(1 \times 10^{-3} \mathrm{M}\right)$; b) The transient absorption spectra of $4 \mathrm{CzIPN}\left(5 \times 10^{-5} \mathrm{M}\right)$ and $1 \mathrm{a}\left(1 \times 10^{-3} \mathrm{M}\right)$ with or without $1 \mathbf{b}\left(1 \times 10^{-3} \mathrm{M}\right)$. 
Next, CV experiments were further carried out to investigate the reaction. As shown in Figure 4, once reduction of Eosin $\mathrm{Y}$ to Eosin $\mathrm{Y}^{-\bullet}$, there was no new peak in the $\mathrm{CV}$ spectra of the mixture of $\mathbf{1 a}$ and $\mathbf{1 b}$ (Figure S13a), indicating that the association of Eosin $\mathrm{Y}^{-\bullet}$ with $\mathbf{1 a}^{+\bullet}$ failed to activate the $\mathbf{1 b}$ from $-1.84 \mathrm{~V}$ vs SCE for $\mathbf{1 b}$ to $-0.87 \mathrm{~V}$ SCE for subsequent electron transfer from Eosin $\mathrm{Y}^{-}$to $\mathbf{1 b}$, thus showing no catalytic activity. The result was also the case with that of $\mathrm{Rh}$ $6 \mathrm{G}$ where no new peak appeared in the presence of $\mathrm{Rh}_{6} \mathrm{G}^{-}$(Figure S13b). For 4CzIPN, a new peak was detected at $-0.85 \mathrm{~V} \mathrm{SCE}$ for $\mathbf{1 b}$ (Figure S13c), indicating that $4 \mathrm{CzIPN}{ }^{-}$have no much influence on the activation of $\mathbf{1}^{+\bullet}$ to $\mathbf{1 b}$, but the following electron transfer from $4 \mathrm{CzIPN}^{-\bullet}$ to $\mathbf{1 b}$ was inefficient.
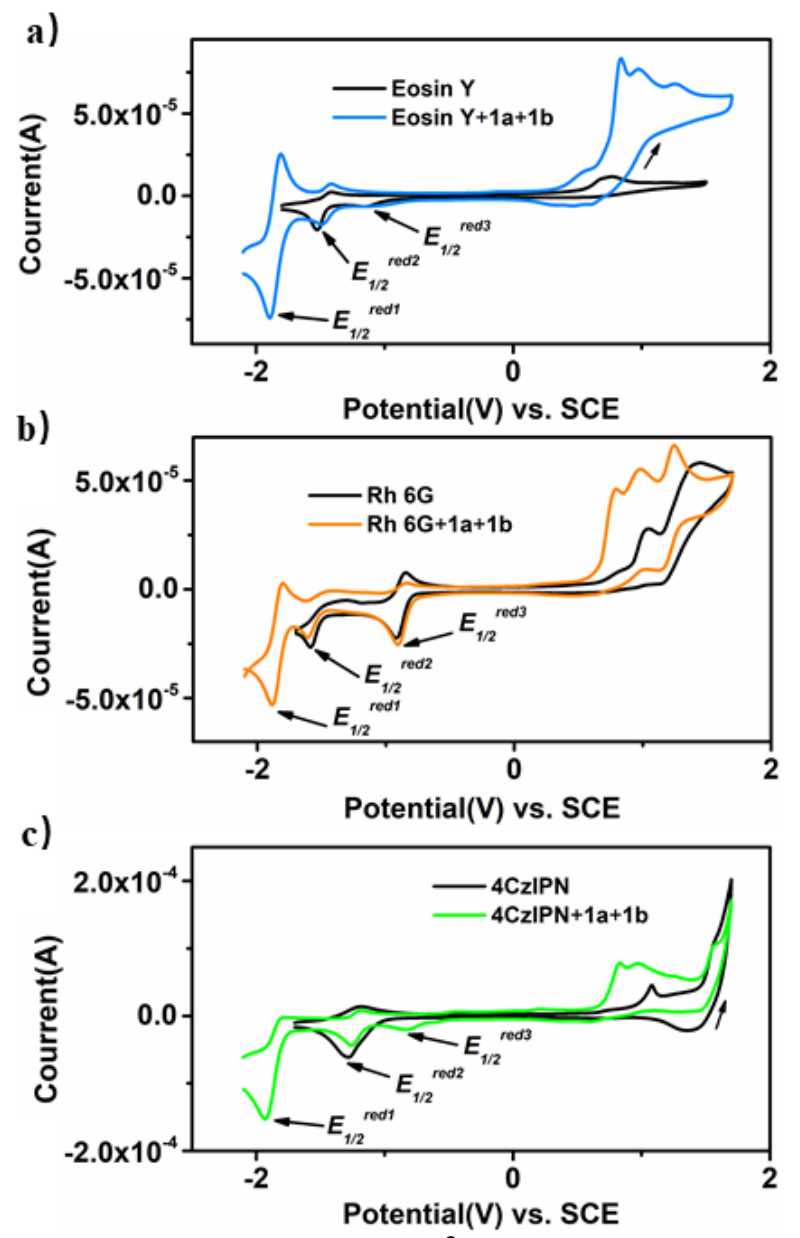

Figure S13. a) The CV spectra of Eosin $\mathrm{Y}\left(1.0 \times 10^{-3} \mathrm{M}\right)$ and $\mathrm{NBu}_{4} \mathrm{PF}_{6}\left(1.0 \times 10^{-1} \mathrm{M}\right)$ in the absence and presence of $1 \mathbf{a}\left(1.0 \times 10^{-3} \mathrm{M}\right)$ and $1 \mathbf{b}\left(1.0 \times 10^{-3} \mathrm{M}\right)$ in degassed $\mathrm{CH}_{3} \mathrm{CN}, E_{1 / 2}{ }^{\text {red1 }}=$ $-1.84 \mathrm{~V} \mathrm{SCE}$ for $1 \mathbf{b}, E_{1 / 2}{ }^{\text {red2 }}=-1.51 \mathrm{~V}$ SCE and $E_{1 / 2^{\text {red3 }}}=-1.17 \mathrm{~V}$ SCE for Eosin Y; b) The CV spectra of Rh $6 \mathrm{G}\left(1.0 \times 10^{-3} \mathrm{M}\right)$ and $\mathrm{NBu}_{4} \mathrm{PF}_{6}\left(1.0 \times 10^{-1} \mathrm{M}\right)$ in the absence and presence of $\mathbf{1 a}$ $\left(1.0 \times 10^{-3} \mathrm{M}\right)$ and $\mathbf{1 b}\left(1.0 \times 10^{-3} \mathrm{M}\right)$ in degassed $\mathrm{CH}_{3} \mathrm{CN}, E_{1 / 2}{ }^{\mathrm{red} 1}=-1.84 \mathrm{~V} \mathrm{SCE}$ for $\mathbf{1 b}, E_{1 / 2}{ }^{\mathrm{red} 2}=$ $-1.59 \mathrm{~V} \mathrm{SCE}$ and $E_{1 / 2^{\text {red3 }}=}=-0.92 \mathrm{~V} \mathrm{SCE}$ for Rh $\left.6 \mathrm{G} ; \mathrm{c}\right)$ The CV spectra of $4 \mathrm{CzIPN}\left(1.0 \times 10^{-3} \mathrm{M}\right)$ and $\mathrm{NBu}_{4} \mathrm{PF}_{6}\left(1.0 \times 10^{-1} \mathrm{M}\right)$ in the absence and presence of $1 \mathbf{a}\left(1.0 \times 10^{-3} \mathrm{M}\right)$ and $1 \mathbf{b}\left(1.0 \times 10^{-3} \mathrm{M}\right)$ in degassed $\mathrm{CH}_{3} \mathrm{CN}, E_{1 / 2}{ }^{\text {red1 }}=-1.84 \mathrm{~V} \mathrm{SCE}$ for $1 \mathbf{b}, E_{1 / 2}{ }^{\text {red2 }}=-1.27 \mathrm{~V} \mathrm{SCE}$ for $4 \mathrm{CzIPN}, E_{1 / 2}{ }^{\text {red3 }}=$ $-0.85 \mathrm{~V}$ SCE for $\mathbf{1 b}$ with $\mathbf{1 \mathbf { a } ^ { + \bullet }}$. 


\subsection{The mechanistic study of hydrazine and hydroxylamine}

To make clear the mechanism of hydrazines and hydroxylamines, heteroaryl hydrazine 85a and hydroxylamine 86a were synthesized and subjected to an array of reaction systems. As shown in Table S2, both hydrazine 85a and heteroaryl hydroxylamine 86a could be converted to their corresponding heteroaryl amine $\mathbf{8 5} \mathbf{c}$ under direct irradiation (at $450 \mathrm{~nm}$ ) with $7 \%$ and $25 \%$ yield (entry 1). With irradiation of 3DPAFIPN and $f a c-\operatorname{Ir}(\mathrm{ppy})_{3}$ as photocatalysts, the yields of heteroaryl amine $\mathbf{8 5 c}$ were increased to $~ 90 \%$ (entries 2-3). The reactions couldn't proceed without irradiation (entry 4). The presence of diverse reductants, such as hydrazine, hydroxylamine, and triethylamine, slightly decreased the yield of products (entries 5-7).

Table S2. The optimization for the synthesis of heteroarylamines ${ }^{a}$

\begin{tabular}{|c|c|c|c|c|c|c|}
\hline & $\begin{array}{r}85 a, \\
86 a\end{array}$ & $\begin{array}{l}=\mathrm{NHCH}_{3} \\
\mathrm{z}=\mathrm{OCH}_{3}\end{array}$ & & & $85 c$ & \\
\hline Entry & $85 \mathbf{a}$ or $86 \mathbf{a}(\mathrm{mmol})$ & photocatalyst & additive & Solvent & Yield $(\mathbf{8 5 a})^{b}$ & Yield $(\mathbf{8 6 a})^{b}$ \\
\hline 1 & 0.2 & - & - & $\mathrm{CH}_{3} \mathrm{CN}$ & $7 \%$ & $25 \%$ \\
\hline 2 & 0.2 & 3DPAFIPN & - & $\mathrm{CH}_{3} \mathrm{CN}$ & $87 \%$ & $90 \%$ \\
\hline 3 & 0.2 & $f a c-\operatorname{Ir}(\mathrm{ppy})_{3}$ & - & $\mathrm{CH}_{3} \mathrm{CN}$ & $92 \%$ & $93 \%$ \\
\hline $4^{c}$ & 0.2 & 3DPAFIPN & - & $\mathrm{CH}_{3} \mathrm{CN}$ & $0 \%$ & $0 \%$ \\
\hline $5^{d}$ & 0.2 & 3DPAFIPN & $t-\mathrm{BuNHNH}_{2}$ & $\mathrm{CH}_{3} \mathrm{CN}$ & $71 \%$ & - \\
\hline $6^{d}$ & 0.2 & 3DPAFIPN & $\mathrm{CH}_{3} \mathrm{NHOCH}_{3}$ & $\mathrm{CH}_{3} \mathrm{CN}$ & - & $74 \%$ \\
\hline 7 & 0.2 & 3DPAFIPN & $\mathrm{Et}_{3} \mathrm{~N}$ & $\mathrm{CH}_{3} \mathrm{CN}$ & $68 \%$ & $72 \%$ \\
\hline
\end{tabular}

${ }^{a}$ Reaction condition: $0.2 \mathrm{mmol}$ ( 1 equiv) $85 \mathrm{a}$ or $86 \mathbf{a}, 0.2 \mathrm{mmol}$ ( 1 equiv) additive, $1.2 \mathrm{~mol} \% \mathrm{PC}$, $3 \mathrm{~mL}$ solvent, Ar, blue LEDs, room temperature. ${ }^{b}$ The yields were determined by ${ }^{1} \mathrm{H}$ NMR using diphenylmethano as the internal standard. ${ }^{c}$ no light. ${ }^{d} 0.2 \mathrm{mmol}$ (1 equiv) hydrazine or hydroxylamine hydrochloride and $0.2 \mathrm{mmol}$ (1 equiv) $\mathrm{K}_{3} \mathrm{PO}_{4}$. 
To figure out the hydrogen source of $\mathrm{N}-\mathrm{H}$ in heteroaryl amine $\mathbf{8 5 c}$, the deuterium labeling experiments showed no deuterated product $\mathbf{8 5} \mathbf{c}$ formation with deuterated acetonitrile $\mathrm{CD}_{3} \mathrm{CN}$ as the solvent (Scheme S5), implying that the hydrogen source was derived from the substrate itself. The cross-coupling reaction of hydroxylamine $67 \mathbf{a}$ and $11 \mathbf{b}$ produced the target $67 \mathbf{c}$ and benzaldehyde as a byproduct (detected by MS), consistent with the speculation of the substrate itself as the hydrogen source.<smiles>CNN(C)c1ccnc2ccccc12</smiles>

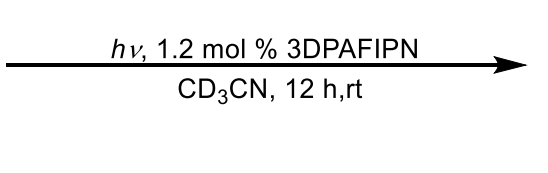<smiles>CON(C)c1ccnc2ccccc12</smiles>

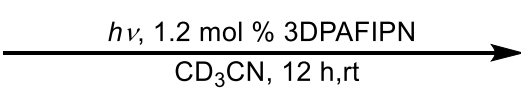

$86 a$<smiles>N#Cc1nccc2ccccc12</smiles>

$\mathrm{CH}_{3} \mathrm{CN}, 12 \mathrm{~h}, \mathrm{rt}$<smiles>CNc1ccnc2ccccc12</smiles>

$85 \mathrm{c}, 85 \%$<smiles>CNc1ccnc2ccccc12</smiles>

$85 \mathrm{c}, 89 \%$

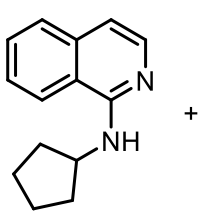

$67 c, 58 \%$<smiles>[2H]N(C)c1ccnc2ccccc12</smiles>

$85 c^{\prime}, 0 \%$<smiles>[2H]N(C)c1ccnc2ccccc12</smiles>

$85 c^{\prime}, 0 \%$<smiles>O=C[Pb]</smiles>

detected by MS

Scheme S5. The deuterium labeling experiments. 
Next, CV investigation found that the reductive potentials of heteroaryl hydrazine $\mathbf{8 5 a}\left(E_{1 / 2}{ }^{\text {red }}=\right.$ $-2.31 \mathrm{~V}$ SCE$)$ and heteroaryl hydroxylamine 86a $\left(E_{1 / 2}{ }^{\text {red }}=-1.99 \mathrm{~V}\right.$ SCE $)$ were too negative to be reduced by $3 \mathrm{DPAFIPN} *\left[E_{1 / 2}\left(\mathrm{PC}^{+} / \mathrm{PC}^{*}\right)=-1.38 \mathrm{~V} \mathrm{SCE}\right]$ and $f a c-\operatorname{Ir}(\mathrm{ppy})_{3}^{*}\left[E_{1 / 2}\left(\mathrm{PC}^{+} / \mathrm{PC}^{*}\right)=\right.$ $-1.73 \mathrm{~V} \mathrm{SCE}$ ] (Figure S14), and the oxidative potentials of hydrazine 85a $\left(E_{1 / 2}{ }^{\mathrm{ox} 1}=+0.45 \mathrm{~V} \mathrm{SCE}\right)$ and heteroaryl hydroxylamine $86 \mathbf{a}\left(E_{1 / 2}{ }^{\mathrm{ox}}=+1.35 \mathrm{~V} \mathrm{SCE}\right)$ were more positive than that of $3 \mathrm{DPAFIPN} *\left[E_{1 / 2}\left(\mathrm{PC}^{+\bullet} / \mathrm{PC}^{*}=+1.09 \mathrm{~V}\right.\right.$ vs SCE$)$ and $f a c-\operatorname{Ir}(\mathrm{ppy}) 3^{*}\left[E_{1 / 2}\left(\mathrm{PC}^{*} / \mathrm{PC}^{-}\right)=+0.31 \mathrm{~V}\right.$ $\mathrm{SCE}]$. Therefore, the reductive fragmentation of $\mathrm{N}-\mathrm{X}(\mathrm{X}=\mathrm{N}, \mathrm{O})$ bond is not thermodynamically feasible.
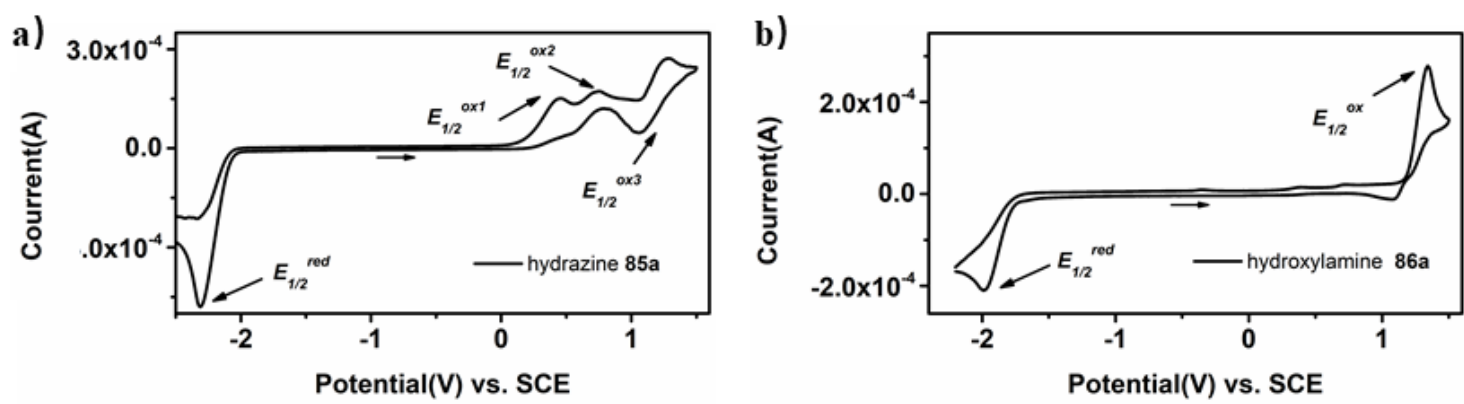

Figure S14. a) The CV spectra of $85 \mathbf{a}\left(5.0 \times 10^{-3} \mathrm{M}\right)$ and $\mathrm{NBu}_{4} \mathrm{PF}_{6}\left(1.0 \times 10^{-1} \mathrm{M}\right)$ in degassed $\mathrm{CH}_{3} \mathrm{CN}, E_{1 / 2}{ }^{\text {red }}=-2.31 \mathrm{~V} \mathrm{SCE}, E_{1 / 2}{ }^{0 \times 1}=+0.45 \mathrm{~V} \mathrm{SCE}, E_{1 / 2}{ }^{0 \times 2}=+0.74 \mathrm{~V} \mathrm{SCE}$ and $E_{1 / 2}{ }^{\text {ox } 3}=+1.17$ V SCE; b) The CV spectra of $\mathbf{8 5 a}\left(5.0 \times 10^{-3} \mathrm{M}\right)$ and $\mathrm{NBu}_{4} \mathrm{PF}_{6}\left(1.0 \times 10^{-1} \mathrm{M}\right)$ in degassed $\mathrm{CH}_{3} \mathrm{CN}$, $E_{1 / 2}{ }^{\text {red }}=-1.99 \mathrm{~V} \mathrm{SCE}, E_{1 / 2}{ }^{0 \mathrm{x}}=+1.35 \mathrm{~V} \mathrm{SCE}$.

A series of spectroscopic experiments were then performed. The UV-vis absorption spectra showed that both of heteroaryl hydrazine 85a and heteroaryl hydroxylamine 86a at reaction concentration absorbed visible light (Figure S15b). Upon direct excitation, the normalized fluorescence at $298 \mathrm{~K}$ and phosphorescence at $77 \mathrm{~K}$ (Figure S15b) revealed the possibility of the triplet energy transfer from 3DPAFIPN* $(55.8 \mathrm{kcal} / \mathrm{mol})$ or $f a c-\operatorname{Ir}(\mathrm{ppy})_{3} *(58.7 \mathrm{kcal} / \mathrm{mol})$ to the substrates 85a and 86a with the triplet energy of $55.5 \mathrm{kcal} / \mathrm{mol}$ and $56.6 \mathrm{kcal} / \mathrm{mol}$, respectively.
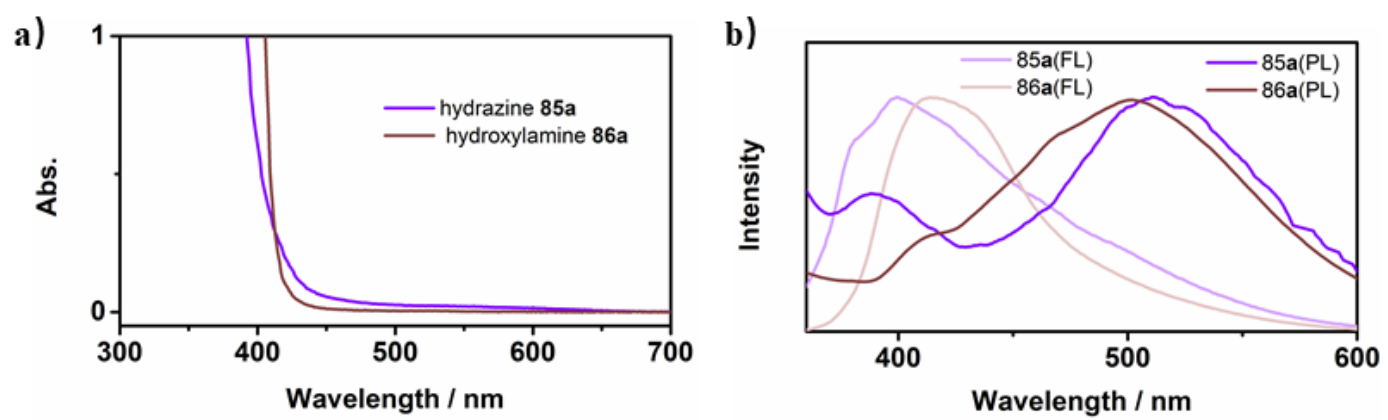

Figure S15. a) Absorption spectra of spectrum of $85 \mathbf{a}\left(6.7 \times 10^{-2} \mathrm{M}\right)$ and $86 \mathbf{a}\left(6.7 \times 10^{-2} \mathrm{M}\right)$ at reaction concentration in $\mathrm{CH}_{3} \mathrm{CN}$; b) The normalized fluorescence at $298 \mathrm{~K}$ and phosphorescence at $77 \mathrm{k}$ of $85 \mathbf{a}\left(1.0 \times 10^{-3} \mathrm{M}\right)$ and $86 \mathbf{a}\left(1.0 \times 10^{-3} \mathrm{M}\right)$ in degassed 2-methyltetrahydrofuran. The triplet energy of $\mathbf{8 5 a}$ and $86 \mathbf{a}$ were $55.5 \mathrm{kcal} / \mathrm{mol}$ and $56.6 \mathrm{kcal} / \mathrm{mol}$ respectively. 
Based on the above experimental observations, a revised plausible mechanism was outlined in Scheme S6 for hydrazine and hydroxylamine as substrates. Under visible light irradiation, 3DPAFIPN (PC) was pumped to its excited state (PC*), and subsequently reduced by hydrazine (or hydroxylamine), leading to the formation of the $N$-radical cation $\mathbf{A}$ along with $\mathrm{PC}^{-\bullet}$. SET reduction of $\mathbf{1 1 b}$ by $\mathrm{PC}^{-\bullet}$ provided the radical anion $\mathbf{B}$, simultaneously regenerating the ground-state photocatalyst PC thereby closing the photocatalytic cycle. $N$-radical cation $\mathbf{A}$ coupled with radical anion $\mathbf{B}$ to produce intermediate $\mathbf{C}$, which eliminated $\mathrm{HCN}$ to afford heteroaryl hydrazine or heteroaryl hydroxylamine D. At last, heteroaryl hydrazine (heteroaryl hydroxylamine D) was homolyzed under direct irradiation or sensitization by photocatalysts, which subsequently underwent hydrogen atom abstract or proton-coupled electron transfer to provide the target heteroaryl amines.

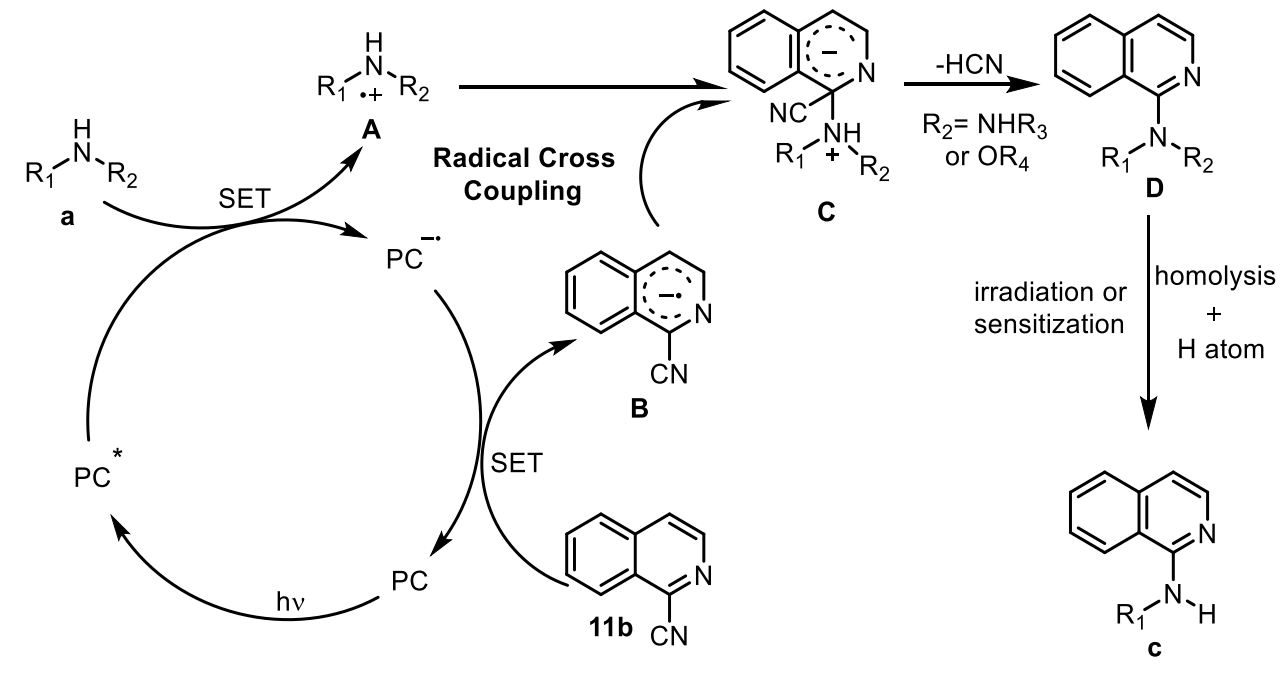

Scheme S6. Possible mechanism for hydrazine and hydroxylamine access to heteroarylamine 


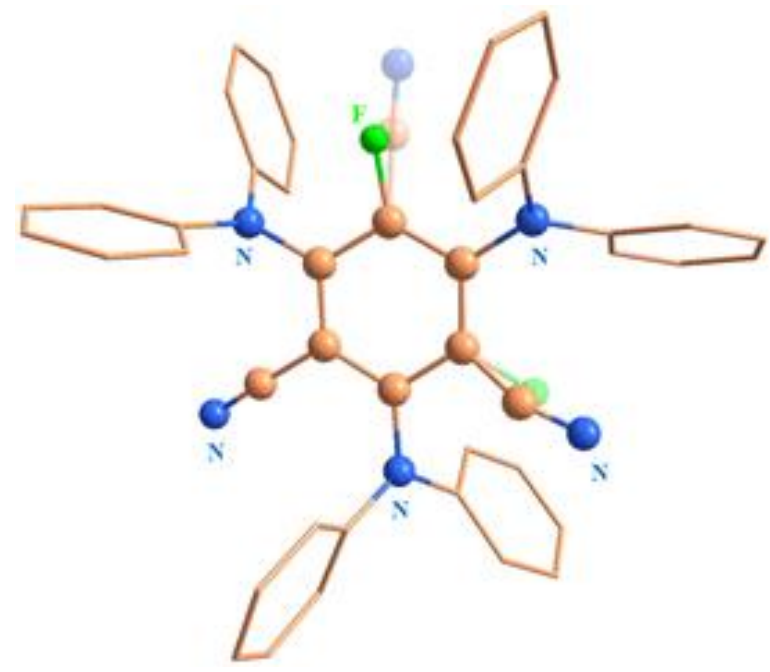

Figure S16. A single crystal was grown by slow diffusion of a solution of 3DPAFIPN in dichloromethane and n-hexane. Supplementary crystallographic data for this compound have been deposited at Cambridge Crystallographic Data Centre (CCDC 2014477) and can be obtained free of charge (DOI: 10.5517/ccdc.csd.cc25m746). 


\section{References}

1. Luo, J.; Zhang, J., ACS Catal. 2016, 6, 873-877.

2. Speckmeier, E.; Fischer, T. G.; Zeitler, K., J. Am. Chem. Soc. 2018, 140, 15353-15365.

3. Garreau, M.; Le Vaillant, F.; Waser, J., Angew. Chem., Int. Ed. 2019, 58, 8182-8186.

4. Wang, H.; Wang, C.; Huang, K.; Liu, L.; Chang, W.; Li, J., Org. Lett. 2016, 18, 2367-2370.

5. Teze, D.; Dion, M.; Daligault, F.; Tran, V.; André-Miral, C.; Tellier, C., Bioorg. Med. Chem. Lett. 2013, 23, 448-451.

6. Gantt, R. W.; Peltier-Pain, P.; Cournoyer, W. J.; Thorson, J. S., Nat. Chem. Biol. 2011, 7, 685-691.

7. Veits, G. K.; Wenz, D. R.; Palmer, L. I.; Amant, A. H. S.; Hein, J. E.; de Alaniz, J. R., Org. Biomol. Chem. 2015, 13, 8465-8469.

8. Grigg, R.; Rankovic, Z.; Thoroughgood, M., Tetrahedron. 2000, 56, 8025-8032.

9. Wertz, S.; Studer., A. Helv. Chim. Acta 2012, 95, 1758-1772.

10. Fujita, M.; Hiyama, T. J., Org. Chem. 1988, 53, 5415-5421.

11. Demeunynck, M.; Tohme, N.; Lhomme, M.-F.; Lhomme, J. J., Heterocyclic Chem., 1984, 21, 501-503.

12. Chen, H.; Sun, S.; Xi, H.; Hu, K.; Zhang, N.; Qu, J.; Zhou, Y., Tetrahedron Lett. 2019, 60, 1434-1436.

13. Guo, S.; Wan, G.; Sun, S.; Jiang, Y.; Yu, J.-T.; Cheng, J., Chem. Commun. 2015, 51, 5085-5088. 


\section{Characterization for all products.}<smiles>CN(c1ccccc1)c1ccccc1</smiles>

1,2-dimethyl-1,2-diphenylhydrazine (aa) The characterization data of aa was same as the reported.<smiles>CN(c1ccccc1)c1ccncc1</smiles>

$N$-methyl- $N$-phenylpyridin-4-amine (1c) The product is obtained as white soild (isolated yield: 98\%): ${ }^{1} \mathrm{H}$ NMR (400 MHz, $\left.\mathrm{CDCl}_{3}\right) \delta 8.20(\mathrm{~d}, J=5.5 \mathrm{~Hz}, 2 \mathrm{H}), 7.43(\mathrm{t}, J=7.7 \mathrm{~Hz}, 2 \mathrm{H}), 7.32$ $7.16(\mathrm{~m}, 3 \mathrm{H}), 6.54(\mathrm{~d}, J=5.7 \mathrm{~Hz}, 2 \mathrm{H}), 3.32(\mathrm{~s}, 3 \mathrm{H}) .{ }^{13} \mathrm{C} \mathrm{NMR}\left(101 \mathrm{MHz}, \mathrm{CDCl}_{3}\right) \delta 153.79$, 149.72, 146.15, 129.96, 126.66, 126.39, 108.28, 39.38. ESI: Calcd.for $\mathrm{C}_{12} \mathrm{H}_{12} \mathrm{~N}_{2}[\mathrm{M}+\mathrm{H}]^{+}$: 185.1079; found: 185.1069 .<smiles>Cc1cc(N(C)c2ccccc2)ccn1</smiles>

$\boldsymbol{N}$,2-dimethyl- $\boldsymbol{N}$-phenylpyridin-4-amine (2c) The product is obtained as white soild (isolated yield: 87\%): ${ }^{1} \mathrm{H} \mathrm{NMR}\left(400 \mathrm{MHz}, \mathrm{CDCl}_{3}\right) \delta 8.10(\mathrm{~d}, J=5.9 \mathrm{~Hz}, 1 \mathrm{H}), 7.42(\mathrm{t}, J=7.8 \mathrm{~Hz}, 2 \mathrm{H})$, 7.33-7.12 (m, 3 H), 6.49-6.33 (m, $2 \mathrm{H}), 3.30$ (s, $3 \mathrm{H}), 2.40$ (s, $3 \mathrm{H}) .{ }^{13} \mathrm{C} \mathrm{NMR}\left(101 \mathrm{MHz}, \mathrm{CDCl}_{3}\right)$ $\delta 158.35,154.28,149.17,146.42,129.88,126.66,126.18,107.33,106.04,39.43,24.70$. ESI: Calcd.for $\mathrm{C}_{13} \mathrm{H}_{14} \mathrm{~N}_{2}[\mathrm{M}+\mathrm{H}]^{+}: 199.1235$; found:199.1221.<smiles>CN(c1ccccc1)c1ccnc(CO)c1</smiles>

(4-(methyl(phenyl)amino)pyridin-2-yl)methanol (3c) The product is obtained as white soild (isolated yield: $88 \%):{ }^{1} \mathrm{H} \mathrm{NMR}\left(400 \mathrm{MHz}, \mathrm{CDCl}_{3}\right) \delta 8.13(\mathrm{~d}, J=6.6 \mathrm{~Hz}, 1 \mathrm{H}), 7.45(\mathrm{t}, J=7.5 \mathrm{~Hz}$, $2 \mathrm{H}), 7.31(\mathrm{t}, J=7.4 \mathrm{~Hz}, 1 \mathrm{H}), 7.21(\mathrm{~d}, J=7.8 \mathrm{~Hz}, 2 \mathrm{H}), 6.48(\mathrm{~s}, 2 \mathrm{H}), 4.61(\mathrm{~s}, 2 \mathrm{H}), 3.35(\mathrm{~s}, 3 \mathrm{H})$. ${ }^{13} \mathrm{C}$ NMR $\left(101 \mathrm{MHz}, \mathrm{CDCl}_{3}\right) \delta 158.98,155.09,147.61,146.05,130.26,126.94,126.81,107.58$, 104.52, 64.17, 39.76. ESI: Calcd. for $\mathrm{C}_{13} \mathrm{H}_{14} \mathrm{~N}_{2} \mathrm{O}[\mathrm{M}+\mathrm{H}]^{+}: 215.1184$; found: 215.1170 .<smiles>CN(c1ccccc1)c1ccnc(C(C)(C)C)c1</smiles>

2-(tert-butyl)- $\boldsymbol{N}$-methyl- $\boldsymbol{N}$-phenylpyridin-4-amine (4c) The product is obtained as white soild (isolated yield: $92 \%):{ }^{1} \mathrm{H} \mathrm{NMR}\left(400 \mathrm{MHz} \mathrm{CDCl}_{3}\right) \delta 8.20(\mathrm{~d}, J=5.8 \mathrm{~Hz}, 1 \mathrm{H}), 7.42(\mathrm{t}, J=7.7 \mathrm{~Hz}$, $2 \mathrm{H}), 7.25(\mathrm{~d}, J=5.9 \mathrm{~Hz}, 1 \mathrm{H}), 7.21(\mathrm{~d}, J=8.1 \mathrm{~Hz}, 2 \mathrm{H}), 6.65(\mathrm{~d}, J=2.0 \mathrm{~Hz}, 1 \mathrm{H}), 6.40(\mathrm{dd}, J=$ 5.8, $2.1 \mathrm{~Hz}, 1 \mathrm{H}), 3.33$ (s, $3 \mathrm{H}), 1.31(\mathrm{~s}, 9 \mathrm{H}) .{ }^{13} \mathrm{C} \mathrm{NMR}\left(101 \mathrm{MHz}, \mathrm{CDCl}_{3}\right) \delta 169.38,154.32$, 
148.61, 146.58, 129.82, 126.42, 125.98, 106.12, 103.68, 39.44, 37.22, 30.15. ESI: Calcd. for $\mathrm{C}_{16} \mathrm{H}_{20} \mathrm{~N}_{2}[\mathrm{M}+\mathrm{H}]^{+}: 241.1705$; found: 241.1689 .<smiles>Cc1cc(-n2cccc2C)cc(C)n1</smiles>

$N$,2,6-trimethyl- $N$-phenylpyridin-4-amine (5c) The product is obtained as white soild (isolated yield: 88\%): ${ }^{1} \mathrm{H}$ NMR $\left(400 \mathrm{MHz}, \mathrm{CDCl}_{3}\right) \delta 7.41(\mathrm{t}, J=7.8 \mathrm{~Hz}, 2 \mathrm{H}), 7.26(\mathrm{~d}, J=6.6 \mathrm{~Hz}, 1 \mathrm{H})$, 7.19 (d, J = 7.6 Hz, $2 \mathrm{H}), 6.27$ (s, $2 \mathrm{H}), 3.29$ (s, $3 \mathrm{H}), 2.38$ (s, $6 \mathrm{H}) .{ }^{13} \mathrm{C} \mathrm{NMR}\left(101 \mathrm{MHz}, \mathrm{CDCl}_{3}\right)$ $\delta 157.72,154.77,146.63,129.82,126.65,126.00,105.07,39.49,24.69$. ESI: Calcd. for $\mathrm{C}_{14} \mathrm{H}_{16} \mathrm{~N}_{2}[\mathrm{M}+\mathrm{H}]^{+}:$213.1392; found: 213.1380 .<smiles></smiles>

2-chloro- $\boldsymbol{N}$-methyl- $\boldsymbol{N}$-phenylpyridin-4-amine (6c) The product is obtained as white soild (isolated yield: $50 \%):{ }^{1} \mathrm{H}$ NMR $\left(400 \mathrm{MHz}, \mathrm{CDCl}_{3}\right) \delta 7.95(\mathrm{~d}, J=5.8 \mathrm{~Hz}, 1 \mathrm{H}), 7.45(\mathrm{t}, J=7.8 \mathrm{~Hz}$, $2 \mathrm{H}), 7.32$ (t, $J=7.4 \mathrm{~Hz}, 1 \mathrm{H}), 7.23-7.15(\mathrm{~m}, 2 \mathrm{H}), 6.53(\mathrm{~d}, J=2.3 \mathrm{~Hz}, 1 \mathrm{H}), 6.43$ (dd, $J=6.0$, $2.3 \mathrm{~Hz}, 1 \mathrm{H}), 3.31(\mathrm{~s}, 3 \mathrm{H}) .{ }^{13} \mathrm{C}$ NMR $\left(101 \mathrm{MHz}, \mathrm{CDCl}_{3}\right) \delta 155.83,152.22,149.09,145.53$, 130.20, 127.05, 126.76, 107.43, 107.01, 39.69. ESI: Calcd. for $\mathrm{C}_{12} \mathrm{H}_{11} \mathrm{ClN}_{2}[\mathrm{M}+\mathrm{H}]^{+}:$219.0689; found: 219.0679 .<smiles>CC(=O)c1cc(N(C)c2ccccc2)ccn1</smiles>

1-(4-(methyl(phenyl)amino)pyridin-2-yl)ethanone (7c) The product is obtained as white soild (isolated yield: $53 \%):{ }^{1} \mathrm{H} \mathrm{NMR}\left(400 \mathrm{MHz}, \mathrm{CDCl}_{3}\right) \delta 8.24(\mathrm{~d}, J=5.8 \mathrm{~Hz}, 1 \mathrm{H}), 7.44(\mathrm{t}, J=7.8 \mathrm{~Hz}$, $2 \mathrm{H}), 7.36(\mathrm{~d}, J=2.7 \mathrm{~Hz}, 1 \mathrm{H}), 7.33-7.26(\mathrm{~m}, 1 \mathrm{H}), 7.24-7.16(\mathrm{~m}, 2 \mathrm{H}), 6.65(\mathrm{dd}, J=5.8,2.7 \mathrm{~Hz}$, $1 \mathrm{H}), 3.37$ (s, $3 \mathrm{H}), 2.68(\mathrm{~s}, 3 \mathrm{H}) .{ }^{13} \mathrm{C}$ NMR $\left(101 \mathrm{MHz}, \mathrm{CDCl}_{3}\right) \delta 155.83,152.22,149.09,145.53$, 130.20, 127.05, 126.76, 107.43, 107.01, 39.69. ${ }^{13} \mathrm{C}$ NMR $\left(101 \mathrm{MHz}, \mathrm{CDCl}_{3}\right) \delta 200.85,154.55$, 154.23, 149.01, 145.83, 130.15, 126.76, 126.61, 111.10, 105.83, 39.67, 26.02. ESI: Calcd. for $\mathrm{C}_{14} \mathrm{H}_{14} \mathrm{~N}_{2} \mathrm{O}[\mathrm{M}+\mathrm{H}]^{+}:$227.1184; found: 227.1168.<smiles>Cn1ncnc1-n1cccc1</smiles>

$\mathrm{N}$-methyl- $\boldsymbol{N}$-phenylpyrimidin-2-amine (8c) The product is obtained as white soild (isolated yield: 33\%): ${ }^{1} \mathrm{H}$ NMR $\left(400 \mathrm{MHz}, \mathrm{CDCl}_{3}\right) \delta 8.34(\mathrm{~d}, J=4.7 \mathrm{~Hz}, 2 \mathrm{H}), 7.41(\mathrm{t}, J=7.8 \mathrm{~Hz}, 2 \mathrm{H})$, $7.32(\mathrm{~d}, J=7.4 \mathrm{~Hz}, 2 \mathrm{H}), 7.25-7.22(\mathrm{~m}, 1 \mathrm{H}), 6.57(\mathrm{t}, J=4.8 \mathrm{~Hz}, 1 \mathrm{H}), 3.53(\mathrm{~s}, 3 \mathrm{H}) .{ }^{13} \mathrm{C}$ NMR $\left(101 \mathrm{MHz}, \mathrm{CDCl}_{3}\right) \quad \delta 161.98,157.64,145.55,129.17,126.56,125.85,110.73,38.68 . \mathrm{ESI}:$ Calcd. for $\mathrm{C}_{11} \mathrm{H}_{11} \mathrm{~N}_{3}[\mathrm{M}+\mathrm{H}]^{+}$: 186.1031; found: 186.1023 . 
<smiles>CN(c1ccccc1)c1cnccn1</smiles>

$\boldsymbol{N}$-methyl- $\boldsymbol{N}$-phenylpyrazin-2-amine (9c) The product is obtained as white soild (isolated yield: 33\%): ${ }^{1} \mathrm{H}$ NMR $\left(400 \mathrm{MHz}, \mathrm{CDCl}_{3}\right) \delta 8.12-8.07(\mathrm{~m}, 1 \mathrm{H}), 7.94(\mathrm{~d}, J=1.2 \mathrm{~Hz}, 1 \mathrm{H}), 7.83(\mathrm{~d}, J=$ $2.7 \mathrm{~Hz}, 1 \mathrm{H}), 7.45(\mathrm{t}, J=7.8 \mathrm{~Hz}, 2 \mathrm{H}), 7.33-7.26(\mathrm{~m}, 3 \mathrm{H}), 3.46(\mathrm{~s}, 3 \mathrm{H}) .{ }^{13} \mathrm{C}$ NMR $(101 \mathrm{MHz}$, $\left.\mathrm{CDCl}_{3}\right) \delta 155.00,144.82,142.07,132.37,131.77,130.17,126.77,126.31,38.30$. ESI: Calcd. for $\mathrm{C}_{11} \mathrm{H}_{11} \mathrm{~N}_{3}[\mathrm{M}+\mathrm{H}]^{+}$: 186.1031; found: 186.1023 .<smiles>CN(c1ccccc1)c1cccnn1</smiles>

$\boldsymbol{N}$-methyl- $\boldsymbol{N}$-phenylpyridazin-3-amine (10c) The product is obtained as white soild (isolated yield: $23 \%):{ }^{1} \mathrm{H}$ NMR $\left(400 \mathrm{MHz}, \mathrm{CDCl}_{3}\right) \delta 8.65(\mathrm{~d}, J=4.0 \mathrm{~Hz}, 1 \mathrm{H}), 7.45(\mathrm{t}, J=7.8 \mathrm{~Hz}, 2 \mathrm{H})$, $7.35-7.21(\mathrm{~m}, 3 \mathrm{H}), 7.07(\mathrm{dd}, J=9.3,4.5 \mathrm{~Hz}, 1 \mathrm{H}), 6.75(\mathrm{dd}, J=9.3,1.1 \mathrm{~Hz}, 1 \mathrm{H}), 3.60(\mathrm{~s}, 3 \mathrm{H})$. ${ }^{13} \mathrm{C}$ NMR $\left(101 \mathrm{MHz}, \mathrm{CDCl}_{3}\right) \delta 159.56,145.47,143.54,130.14,126.67,126.56,126.39,114.14$, 38.86. ESI: Calcd. for $\mathrm{C}_{11} \mathrm{H}_{11} \mathrm{~N}_{3}[\mathrm{M}+\mathrm{Na}]^{+}: 208.0851$; found: 208.0841 .<smiles>CN(c1ccccc1)c1nccc2ccccc12</smiles>

$\boldsymbol{N}$-methyl- $\boldsymbol{N}$-phenylisoquinolin-1-amine (11c) The product is obtained as white soild (isolated yield: 98\%): ${ }^{1} \mathrm{H}$ NMR $\left(400 \mathrm{MHz}, \mathrm{CDCl}_{3}\right) \delta 8.29(\mathrm{~d}, J=5.7 \mathrm{~Hz}, 1 \mathrm{H}), 7.71(\mathrm{dd}, J=16.5,8.4 \mathrm{~Hz}$, $2 \mathrm{H}), 7.52(\mathrm{t}, J=7.5 \mathrm{~Hz}, 1 \mathrm{H}), 7.33(\mathrm{~d}, J=5.7 \mathrm{~Hz}, 1 \mathrm{H}), 7.28-7.19(\mathrm{~m}, 3 \mathrm{H}), 6.96(\mathrm{t}, J=7.3 \mathrm{~Hz}$, $1 \mathrm{H}), 6.90(\mathrm{~d}, J=7.9 \mathrm{~Hz}, 2 \mathrm{H}), 3.59(\mathrm{~s}, 3 \mathrm{H}) .{ }^{13} \mathrm{CNMR}\left(101 \mathrm{MHz}, \mathrm{CDCl}_{3}\right) \delta 158.65,150.97$, 141.31, 138.53, 129.73, 129.41, 127.11, 126.96, 126.32, 123.13, 122.37, 121.36, 116.92, 41.54. ESI: Calcd. for $\mathrm{C}_{16} \mathrm{H}_{14} \mathrm{~N}_{2}[\mathrm{M}+\mathrm{H}]^{+}:$235.1235; found: 235.1224 .<smiles>CN(c1ccccc1)c1nccc2cc(Br)ccc12</smiles>

6-bromo- $\boldsymbol{N}$-methyl- $\boldsymbol{N}$-phenylisoquinolin-1-amine (12c) The product is obtained as white soild (isolated yield: 55\%): ${ }^{1} \mathrm{H}$ NMR $\left(400 \mathrm{MHz} \mathrm{CDCl}_{3}\right) \delta 8.27(\mathrm{~d}, J=5.6 \mathrm{~Hz}, 1 \mathrm{H}), 7.88(\mathrm{~s}, 1 \mathrm{H}), 7.48$ $(\mathrm{d}, J=9.0 \mathrm{~Hz}, 1 \mathrm{H}), 7.30-7.18(\mathrm{~m}, 4 \mathrm{H}), 7.02(\mathrm{t}, J=7.3 \mathrm{~Hz}, 1 \mathrm{H}), 6.93(\mathrm{~d}, J=7.8 \mathrm{~Hz}, 2 \mathrm{H}), 3.58$ (s, $3 \mathrm{H}) .{ }^{13} \mathrm{C}$ NMR $\left(101 \mathrm{MHz}, \mathrm{CDCl}_{3}\right) \delta 158.39,150.69,142.17,139.57,129.47,129.37,129.02$, 128.68, 124.23, 123.10, 122.17, 120.86, 115.20, 41.73. ESI: Calcd. for $\mathrm{C}_{16} \mathrm{H}_{13} \mathrm{BrN}_{2}[\mathrm{M}+\mathrm{H}]^{+}$: 314.0340; found: 313.0331.<smiles>CN(c1ccccc1)c1ccc2ccccc2n1</smiles>

$\boldsymbol{N}$-methyl- $\boldsymbol{N}$-phenylquinolin-2-amine (13c) The product is obtained as white soild (isolated yield: $70 \%):{ }^{1} \mathrm{H}$ NMR (400 MHz, $\left.\mathrm{CDCl}_{3}\right) \delta 7.79(\mathrm{~d}, J=8.2 \mathrm{~Hz}, 1 \mathrm{H}), 7.67(\mathrm{~d}, J=9.1 \mathrm{~Hz}, 1 \mathrm{H})$, 
$7.55(\mathrm{t}, J=8.4 \mathrm{~Hz}, 2 \mathrm{H}), 7.42(\mathrm{t}, J=7.8 \mathrm{~Hz}, 2 \mathrm{H}), 7.33-7.18(\mathrm{~m}, 4 \mathrm{H}), 6.73(\mathrm{~d}, J=9.1 \mathrm{~Hz}, 1 \mathrm{H})$, $3.63(\mathrm{~s}, 3 \mathrm{H}) .{ }^{13} \mathrm{C}$ NMR $\left(101 \mathrm{MHz}, \mathrm{CDCl}_{3}\right) \delta 157.14,147.96,146.60,136.32,129.84,129.44$, 127.30, 126.74, 126.69, 125.92, 123.39, 122.49, 112.13, 38.67. ESI: Calcd. for $\mathrm{C}_{16} \mathrm{H}_{14} \mathrm{~N}_{2}$ $[\mathrm{M}+\mathrm{H}]^{+}:$235.1235; found: 235.1221 .<smiles>CN(c1ccccc1)c1ccc2cc(Br)ccc2n1</smiles>

6-bromo- $\boldsymbol{N}$-methyl- $\boldsymbol{N}$-phenylquinolin-2-amine (14c) The product is obtained as white soild (isolated yield: $51 \%):{ }^{1} \mathrm{H} \mathrm{NMR}\left(400 \mathrm{MHz}, \mathrm{CDCl}_{3}\right) \delta$ 7.76-7.56 (m, $\left.4 \mathrm{H}\right), 7.45(\mathrm{t}, J=7.6 \mathrm{~Hz}, 2$ $\mathrm{H}), 7.34-7.26(\mathrm{~m}, 3 \mathrm{H}), 6.73(\mathrm{~d}, J=9.1 \mathrm{~Hz}, 1 \mathrm{H}), 3.62(\mathrm{~s}, 3 \mathrm{H}) .{ }^{13} \mathrm{C} \mathrm{NMR}\left(101 \mathrm{MHz}, \mathrm{CDCl}_{3}\right) \delta$ 175.26, 157.50, 141.51, 140.16, 138.06, 134.42, 129.25, 126.76, 126.67, 126.59, 126.09, 126.05, 125.68, 122.75, 121.59, 116.61, 53.64, 33.57. ${ }^{13} \mathrm{C}$ NMR (101 MHz, Chloroform-d) $\delta 157.17$, 146.67, 146.11, 135.33, 132.60, 129.96, 129.30, 128.37, 126.79, 126.32, 124.48, 115.24, 112.80, 38.71. ESI: Calcd. for $\mathrm{C}_{16} \mathrm{H}_{13} \mathrm{BrN}_{2}[\mathrm{M}+\mathrm{H}]^{+}: 314.0340$; found: 313.0328 .<smiles>Cc1cc(N(C)c2ccccc2)nc2ccccc12</smiles>

$\boldsymbol{N}$,4-dimethyl- $\boldsymbol{N}$-phenylquinolin-2-amine (15c) The product is obtained as white soild (isolated yield: 85\%): ${ }^{1} \mathrm{H}$ NMR $\left(400 \mathrm{MHz}, \mathrm{CDCl}_{3}\right) \delta 7.86-7.74(\mathrm{~m}, 2 \mathrm{H}), 7.58(\mathrm{t}, J=7.5 \mathrm{~Hz}, 1 \mathrm{H}), 7.45(\mathrm{t}$, $J=7.5 \mathrm{~Hz}, 2 \mathrm{H}), 7.34-7.25(\mathrm{~m}, 4 \mathrm{H}), 6.62(\mathrm{~s}, 1 \mathrm{H}), 3.65(\mathrm{~s}, 3 \mathrm{H}), 2.46(\mathrm{~s}, 3 \mathrm{H}) .{ }^{13} \mathrm{C} \mathrm{NMR}(101$ $\left.\mathrm{MHz}, \mathrm{CDCl}_{3}\right) \delta 156.95,147.88,146.68,144.05,129.81,129.24,127.16,126.65,125.78,123.80$, 123.55, 122.33, 112.19, 38.61, 18.93. ESI: Calcd. for $\mathrm{C}_{17} \mathrm{H}_{16} \mathrm{~N}_{2}[\mathrm{M}+\mathrm{H}]^{+}$: 249.1392; found: 249.1379.<smiles>CN(c1ccccc1)c1ccnc2ccccc12</smiles>

$N$-methyl- $N$-phenylquinolin-4-amine (16c) The product is obtained as white soild (isolated yield: 50\%): ${ }^{1} \mathrm{H}$ NMR (400 MHz, $\left.\mathrm{CDCl}_{3}\right) \delta 8.83(\mathrm{~d}, J=4.9 \mathrm{~Hz}, 1 \mathrm{H}), 8.09(\mathrm{~d}, J=8.5 \mathrm{~Hz}, 1 \mathrm{H})$, $7.71(\mathrm{~d}, J=8.5 \mathrm{~Hz}, 1 \mathrm{H}), 7.62(\mathrm{t}, J=7.6 \mathrm{~Hz}, 1 \mathrm{H}), 7.31(\mathrm{t}, J=7.6 \mathrm{~Hz}, 1 \mathrm{H}), 7.27-7.21(\mathrm{~m}, 2 \mathrm{H})$, $7.13(\mathrm{~d}, J=4.9 \mathrm{~Hz}, 1 \mathrm{H}), 6.96(\mathrm{t}, J=7.3 \mathrm{~Hz}, 1 \mathrm{H}), 6.88(\mathrm{~d}, J=8.2 \mathrm{~Hz}, 2 \mathrm{H}), 3.48(\mathrm{~s}, 3 \mathrm{H}) .{ }^{13} \mathrm{C}$ NMR $\left(101 \mathrm{MHz}, \mathrm{CDCl}_{3}\right) \delta 153.82,150.91,149.86,149.66,129.77,129.33,129.27,125.65$, 124.68, 124.50, 121.61, 119.30, 114.23, 41.87. ESI: Calcd. for $\mathrm{C}_{16} \mathrm{H}_{14} \mathrm{~N}_{2}[\mathrm{M}+\mathrm{H}]^{+}:$235.1235; found: 235.1220 .<smiles>Cc1ccc(N(C)c2nccc3ccccc23)cc1</smiles>

$\boldsymbol{N}$-methyl- $\boldsymbol{N}$-(p-tolyl)isoquinolin-1-amine (17c) The product is obtained as white soild (isolated yield: 92\%): ${ }^{1} \mathrm{H}$ NMR (400 MHz, $\left.\mathrm{CDCl}_{3}\right) \delta 8.25(\mathrm{~d}, J=5.7 \mathrm{~Hz}, 1 \mathrm{H}), 7.68(\mathrm{dd}, J=12.4,8.5 \mathrm{~Hz}$, $2 \mathrm{H}), 7.48(\mathrm{t}, J=7.5 \mathrm{~Hz}, 1 \mathrm{H}), 7.34-7.12(\mathrm{~m}, 2 \mathrm{H}), 7.02(\mathrm{~d}, J=7.9 \mathrm{~Hz}, 2 \mathrm{H}), 6.84(\mathrm{~d}, J=7.7 \mathrm{~Hz}$, $2 \mathrm{H}), 3.55$ (s, $3 \mathrm{H}), 2.27$ (s, $3 \mathrm{H}) .{ }^{13} \mathrm{C} \mathrm{NMR}\left(101 \mathrm{MHz}, \mathrm{CDCl}_{3}\right) \delta 158.56,148.69,141.02,138.27$, 
132.31, 129.93, 129.35, 126.94, 126.88, 125.87, 122.52, 122.23, 116.13, 41.94, 20.76. ESI:

Calcd. for $\mathrm{C}_{17} \mathrm{H}_{16} \mathrm{~N}_{2}[\mathrm{M}+\mathrm{H}]^{+}$: 249.1392; found: 249.1376 .<smiles>COc1ccc(-n2c3cccc-3cnc2C)cc1</smiles>

$N$-(4-methoxyphenyl)- $N$-methylisoquinolin-1-amine (18c) The product is obtained as white soild (isolated yield: $94 \%):{ }^{1} \mathrm{H}$ NMR $\left(400 \mathrm{MHz}, \mathrm{CDCl}_{3}\right) \delta 8.22(\mathrm{~d}, J=5.6 \mathrm{~Hz}, 1 \mathrm{H}), 7.64(\mathrm{dd}, J=$ 17.2, 8.4 Hz, $2 \mathrm{H}), 7.45(\mathrm{t}, J=7.4 \mathrm{~Hz}, 1 \mathrm{H}), 7.30-7.10(\mathrm{~m}, 2 \mathrm{H}), 6.93(\mathrm{~d}, J=8.5 \mathrm{~Hz}, 2 \mathrm{H}), 6.78$ $(\mathrm{d}, J=8.5 \mathrm{~Hz}, 2 \mathrm{H}), 3.74(\mathrm{~s}, 3 \mathrm{H}), 3.52(\mathrm{~s}, 3 \mathrm{H}) .{ }^{13} \mathrm{C} \mathrm{NMR}\left(101 \mathrm{MHz}, \mathrm{CDCl}_{3}\right) \delta 158.47,155.91$, 144.80, 140.73, 138.30, 129.22, 126.99, 126.86, 125.67, 124.62, 122.00, 115.57, 114.75, 55.44, 42.64. ESI: Calcd. for $\mathrm{C}_{17} \mathrm{H}_{16} \mathrm{~N}_{2} \mathrm{O}[\mathrm{M}+\mathrm{H}]^{+}: 265.1341$; found: 265.1331 .<smiles></smiles>

$\mathrm{N}$-(4-fluorophenyl)- $\mathrm{N}$-methylisoquinolin-1-amine (19c) The product is obtained as white soild (isolated yield: $92 \%):{ }^{1} \mathrm{H}$ NMR $\left(400 \mathrm{MHz}, \mathrm{CDCl}_{3}\right) \delta 8.26(\mathrm{~d}, J=5.7 \mathrm{~Hz}, 1 \mathrm{H}), 7.72(\mathrm{~d}, J=8.2$ $\mathrm{Hz}, 1 \mathrm{H}), 7.65(\mathrm{~d}, J=8.6 \mathrm{~Hz}, 1 \mathrm{H}), 7.51(\mathrm{t}, J=7.5 \mathrm{~Hz}, 1 \mathrm{H}), 7.31(\mathrm{~d}, J=5.7 \mathrm{~Hz}, 1 \mathrm{H}), 7.25(\mathrm{t}, J$ $=7.7 \mathrm{~Hz}, 1 \mathrm{H}), 6.98-6.84(\mathrm{~m}, 4 \mathrm{H}), 3.54(\mathrm{~s}, 3 \mathrm{H}) .{ }^{13} \mathrm{C}$ NMR $(101 \mathrm{MHz}$, Chloroform- $d$ ) $\delta 158.63$ $(\mathrm{d}, J=242.4 \mathrm{~Hz}), 158.39,147.28(\mathrm{~d}, J=3.1 \mathrm{~Hz}), 141.02,138.34,129.52,127.01,126.63$, $126.11,123.42(\mathrm{~d}, J=8.3 \mathrm{~Hz}), 122.40,116.56,116.01(\mathrm{~d}, J=22.5 \mathrm{~Hz}), 42.06 .{ }^{19} \mathrm{~F}$ NMR $(377$ $\left.\mathrm{MHz}, \mathrm{CDCl}_{3}\right) \delta$-120.50. ESI: Calcd. for $\mathrm{C}_{16} \mathrm{H}_{13} \mathrm{FN}_{2}[\mathrm{M}+\mathrm{H}]^{+}: 253.1141$; found: 253.1123 .<smiles>Cn1ccnc1-c1ccccc1</smiles>

$N$-(4-chlorophenyl)- $\mathrm{N}$-methylisoquinolin-1-amine (20c) The product is obtained as white soild (isolated yield: 89\%): ${ }^{1} \mathrm{H}$ NMR (400 MHz, $\left.\mathrm{CDCl}_{3}\right) \delta 8.30(\mathrm{~d}, J=5.7 \mathrm{~Hz}, 1 \mathrm{H}), 7.77(\mathrm{~d}, J=8.2$ $\mathrm{Hz}, 1 \mathrm{H}), 7.70(\mathrm{~d}, J=8.5 \mathrm{~Hz}, 1 \mathrm{H}), 7.57(\mathrm{t}, J=7.5 \mathrm{~Hz}, 1 \mathrm{H}), 7.39(\mathrm{~d}, J=5.7 \mathrm{~Hz}, 1 \mathrm{H}), 7.33(\mathrm{t}, J$ $=7.7 \mathrm{~Hz}, 1 \mathrm{H}), 7.16(\mathrm{~d}, J=8.7 \mathrm{~Hz}, 2 \mathrm{H}), 6.80(\mathrm{~d}, J=8.7 \mathrm{~Hz}, 2 \mathrm{H}), 3.56(\mathrm{~s}, 3 \mathrm{H}) .{ }^{13} \mathrm{C}$ NMR $(101$ $\left.\mathrm{MHz}, \mathrm{CDCl}_{3}\right) \delta 158.10,149.06,141.15,138.39,129.86,129.19,127.10,126.82,126.58,126.43$, 122.98, 121.52, 117.43, 41.13. ESI: Calcd. for $\mathrm{C}_{16} \mathrm{H}_{13} \mathrm{ClN}_{2}[\mathrm{M}+\mathrm{H}]^{+}:$: 269.0846; found: 269.0833 .<smiles>CCn1ncc2ccccc21</smiles>

$\mathrm{N}$-ethyl- $\mathrm{N}$-phenylisoquinolin-1-amine (21c) The product is obtained as white soild (isolated yield: $98 \%):{ }^{1} \mathrm{H}$ NMR $\left(400 \mathrm{MHz}, \mathrm{CDCl}_{3}\right) \delta 8.28(\mathrm{~d}, J=5.7 \mathrm{~Hz}, 1 \mathrm{H}), 7.69(\mathrm{dd}, J=13.0,8.4 \mathrm{~Hz}$, $2 \mathrm{H}), 7.49(\mathrm{t}, J=7.5 \mathrm{~Hz}, 1 \mathrm{H}), 7.31(\mathrm{~d}, J=5.7 \mathrm{~Hz}, 1 \mathrm{H}), 7.25-7.12(\mathrm{~m}, 3 \mathrm{H}), 6.93(\mathrm{t}, J=7.3 \mathrm{~Hz}$, $1 \mathrm{H}), 6.86(\mathrm{~d}, J=8.0 \mathrm{~Hz}, 2 \mathrm{H}), 4.16(\mathrm{q}, J=7.0 \mathrm{~Hz}, 2 \mathrm{H}), 1.32(\mathrm{t}, J=7.0 \mathrm{~Hz}, 3 \mathrm{H}) .{ }^{13} \mathrm{C}$ NMR $(101$ $\left.\mathrm{MHz}, \mathrm{CDCl}_{3}\right) \delta 157.59,149.63,141.26,138.47,129.42,129.21,126.91,126.88,126.02,123.34$, 121.91, 121.54, 116.58, 47.96, 13.72. ESI: Calcd. for $\mathrm{C}_{17} \mathrm{H}_{16} \mathrm{~N}_{2}[\mathrm{M}+\mathrm{H}]^{+}:$: 249.1392; found: 249.1381 . 


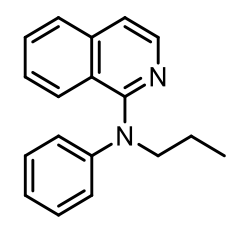

$N$-phenyl-N-propylisoquinolin-1-amine (22c) The product is obtained as white soild (isolated yield: 96\%): ${ }^{1} \mathrm{H}$ NMR (400 MHz, $\left.\mathrm{CDCl}_{3}\right) \delta 8.29(\mathrm{~d}, J=5.7 \mathrm{~Hz}, 1 \mathrm{H}), 7.70(\mathrm{t}, J=9.0 \mathrm{~Hz}, 2 \mathrm{H})$, $7.50(\mathrm{t}, J=7.5 \mathrm{~Hz}, 1 \mathrm{H}), 7.32(\mathrm{~d}, J=5.7 \mathrm{~Hz}, 1 \mathrm{H}), 7.27-7.14(\mathrm{~m}, 3 \mathrm{H}), 6.92(\mathrm{t}, J=7.3 \mathrm{~Hz}, 1 \mathrm{H})$, $6.85(\mathrm{~d}, J=7.8 \mathrm{~Hz}, 2 \mathrm{H}), 4.14-3.95(\mathrm{~m}, 2 \mathrm{H}), 1.83-1.72(\mathrm{~m}, 2 \mathrm{H}), 0.98(\mathrm{t}, J=7.4 \mathrm{~Hz}, 3 \mathrm{H}) .{ }^{13} \mathrm{C}$ NMR $\left(101 \mathrm{MHz} \mathrm{CDCl}_{3}\right) \delta 157.53,150.42,141.17,138.48,129.47,129.17,126.93,126.86$, 126.12, 123.50, 121.72, 121.19, 116.71, 55.36, 21.73, 11.79. ESI: Calcd. for $\mathrm{C}_{18} \mathrm{H}_{18} \mathrm{~N}_{2}[\mathrm{M}+\mathrm{H}]^{+}$: 263.1548; found: 263.1542 .<smiles>CC(C)N(c1ccccc1)c1nccc2ccccc12</smiles>

$N$-isopropyl- $N$-phenylisoquinolin-1-amine (23c) The product is obtained as white soild (isolated yield: 96\%): ${ }^{1} \mathrm{H} \mathrm{NMR}\left(400 \mathrm{MHz}, \mathrm{CDCl}_{3}\right) \delta 8.31(\mathrm{~d}, J=5.7 \mathrm{~Hz}, 1 \mathrm{H}), 7.78(\mathrm{~d}, J=8.5$ $\mathrm{Hz}, 1 \mathrm{H}), 7.69$ (d, $J=8.2 \mathrm{~Hz}, 1 \mathrm{H}), 7.53-7.43$ (m, $1 \mathrm{H}), 7.34$ (d, $J=5.7 \mathrm{~Hz}, 1 \mathrm{H}), 7.27-7.12$ (m, $3 \mathrm{H}), 6.94(\mathrm{t}, J=7.4 \mathrm{~Hz}, 1 \mathrm{H}), 6.89-6.80(\mathrm{~m}, 2 \mathrm{H}), 4.88$ (hept, $J=6.7 \mathrm{~Hz}, 1 \mathrm{H}), 1.34(\mathrm{~d}, J=6.7$ $\mathrm{Hz}, 6 \mathrm{H}) .{ }^{13} \mathrm{C} \mathrm{NMR}\left(101 \mathrm{MHz}, \mathrm{CDCl}_{3}\right) \delta 158.18,148.22,141.21,138.63,129.39,129.07,127.06$, 126.87, 126.28, 124.90, 123.66, 122.34, 117.07, 51.53, 21.48. ESI: Calcd. for $\mathrm{C}_{18} \mathrm{H}_{18} \mathrm{~N}_{2}[\mathrm{M}+\mathrm{H}]^{+}$: 263.1548; found: 263.1537.<smiles>c1ccc(N(c2ccccc2)C2CCCCC2)cc1</smiles>

$N$-cyclohexyl- $N$-phenylisoquinolin-1-amine (24c) The product is obtained as white soild (isolated yield: 96\%): ${ }^{1} \mathrm{H} \mathrm{NMR}\left(400 \mathrm{MHz}, \mathrm{CDCl}_{3}\right) \delta 8.34(\mathrm{~d}, J=5.6 \mathrm{~Hz}, 1 \mathrm{H}), 7.83(\mathrm{~d}, J=8.5$ $\mathrm{Hz}, 1 \mathrm{H}), 7.71(\mathrm{~d}, J=8.2 \mathrm{~Hz}, 1 \mathrm{H}), 7.50(\mathrm{t}, J=7.5 \mathrm{~Hz}, 1 \mathrm{H}), 7.38(\mathrm{~d}, J=5.6 \mathrm{~Hz}, 1 \mathrm{H}), 7.25(\mathrm{t}, J$ $=7.7 \mathrm{~Hz}, 1 \mathrm{H}), 7.16(\mathrm{t}, J=7.5 \mathrm{~Hz}, 2 \mathrm{H}), 6.91(\mathrm{t}, J=7.2 \mathrm{~Hz}, 1 \mathrm{H}), 6.80(\mathrm{~d}, J=7.9 \mathrm{~Hz}, 2 \mathrm{H}), 4.42$ $(\mathrm{t}, J=10.9 \mathrm{~Hz}, 1 \mathrm{H}), 2.05(\mathrm{~d}, J=11.5 \mathrm{~Hz}, 2 \mathrm{H}), 1.78(\mathrm{~d}, J=12.4 \mathrm{~Hz}, 2 \mathrm{H}), 1.63(\mathrm{~d}, J=13.0 \mathrm{~Hz}$, $1 \mathrm{H}), 1.46(\mathrm{dp}, J=25.6,12.6 \mathrm{~Hz}, 4 \mathrm{H}), 1.09(\mathrm{q}, J=12.5 \mathrm{~Hz}, 1 \mathrm{H}) .{ }^{13} \mathrm{C} \mathrm{NMR}\left(101 \mathrm{MHz}, \mathrm{CDCl}_{3}\right)$ $\delta 157.85,148.11,141.22,138.49,129.48,128.93,126.95,126.76,126.39,125.36,122.30$, 121.55, 117.44, 59.50, 31.93, 26.41, 25.97. ESI: Calcd. for $\mathrm{C}_{21} \mathrm{H}_{22} \mathrm{~N}_{2}[\mathrm{M}+\mathrm{H}]^{+}: 303.1861$; found: 303.1849 .<smiles>c1ccc2c(c1)CCCN2c1nccc2ccccc12</smiles>

1-(isoquinolin-1-yl)-1,2,3,4-tetrahydroquinoline (25c) The product is obtained as white soild (isolated yield: $95 \%):{ }^{1} \mathrm{H} \mathrm{NMR}\left(400 \mathrm{MHz}, \mathrm{CDCl}_{3}\right) \delta 8.35(\mathrm{~d}, J=4.6 \mathrm{~Hz}, 1 \mathrm{H}), 7.95(\mathrm{~d}, J=8.4$ $\mathrm{Hz}, 1 \mathrm{H}), 7.80(\mathrm{~d}, J=8.1 \mathrm{~Hz}, 1 \mathrm{H}), 7.61(\mathrm{t}, J=7.3 \mathrm{~Hz}, 1 \mathrm{H}), 7.54-7.35(\mathrm{~m}, 2 \mathrm{H}), 7.11(\mathrm{~d}, J=7.1$ $\mathrm{Hz}, 1 \mathrm{H}), 6.78(\mathrm{dt}, J=21.2,7.1 \mathrm{~Hz}, 2 \mathrm{H}), 6.24(\mathrm{~d}, J=7.9 \mathrm{~Hz}, 1 \mathrm{H}), 3.98-3.72(\mathrm{~m}, 2 \mathrm{H}), 2.97$ (t, $J$ $=6.1 \mathrm{~Hz}, 2 \mathrm{H}), 2.23-2.03(\mathrm{~m}, 2 \mathrm{H}) .{ }^{13} \mathrm{C} \mathrm{NMR}\left(101 \mathrm{MHz}, \mathrm{CDCl}_{3}\right) \delta 158.32,144.86,141.95$, 
$138.35,130.12,129.29,127.11,126.82,126.38,126.18,125.20,124.32,119.63,118.06,117.05$, 49.29, 27.56, 23.28. ESI: Calcd. for $\mathrm{C}_{18} \mathrm{H}_{16} \mathrm{~N}_{2}[\mathrm{M}+\mathrm{H}]^{+}$: 261.1392; found: 261.1380.<smiles>c1ccc(CN(c2ccccc2)c2nccc3ccccc23)cc1</smiles>

$N$-benzyl- $N$-phenylisoquinolin-1-amine (26c) The product is obtained as white soild (isolated yield: $92 \%):{ }^{1} \mathrm{H}$ NMR $\left(400 \mathrm{MHz}, \mathrm{CDCl}_{3}\right) \delta 8.26(\mathrm{~d}, J=5.6 \mathrm{~Hz}, 1 \mathrm{H}), 7.82(\mathrm{~d}, J=8.5 \mathrm{~Hz}, 1 \mathrm{H})$, $7.72(\mathrm{~d}, J=8.2 \mathrm{~Hz}, 1 \mathrm{H}), 7.51(\mathrm{t}, J=7.5 \mathrm{~Hz}, 1 \mathrm{H}), 7.45(\mathrm{~d}, J=7.5 \mathrm{~Hz}, 2 \mathrm{H}), 7.32(\mathrm{~d}, J=5.7 \mathrm{~Hz}$, $1 \mathrm{H}), 7.25$ (p, $J=6.4,5.6 \mathrm{~Hz}, 3 \mathrm{H}), 7.18-7.11(\mathrm{~m}, 3 \mathrm{H}), 6.90(\mathrm{t}, J=7.3 \mathrm{~Hz}, 1 \mathrm{H}), 6.84(\mathrm{~d}, J=7.9$ $\mathrm{Hz}, 2 \mathrm{H}), 5.43$ (s, $2 \mathrm{H}) .{ }^{13} \mathrm{C}$ NMR $\left(101 \mathrm{MHz}, \mathrm{CDCl}_{3}\right) \delta 157.34,150.43,141.31,140.36,138.63$, 129.68, 129.21, 128.47, 127.29, 127.17, 126.83, 126.75, 126.42, 123.37, 122.05, 120.79, 117.29, 57.05. ESI: Calcd. for $\mathrm{C}_{22} \mathrm{H}_{18} \mathrm{~N}_{2}[\mathrm{M}+\mathrm{H}]^{+}: 311.1548$; found: 311.1537 .<smiles>c1ccc(N(c2ccccc2)c2nccc3ccccc23)cc1</smiles>

$\boldsymbol{N}, \boldsymbol{N}$-diphenylisoquinolin-1-amine (27c) The product is obtained as white soild (isolated yield: 99\%): ${ }^{1} \mathrm{H}$ NMR (400 MHz, $\left.\mathrm{CDCl}_{3}\right) \delta 8.38(\mathrm{~d}, J=5.7 \mathrm{~Hz}, 1 \mathrm{H}), 7.98(\mathrm{~d}, J=8.5 \mathrm{~Hz}, 1 \mathrm{H}), 7.85(\mathrm{~d}$, $J=8.2 \mathrm{~Hz}, 1 \mathrm{H}), 7.68-7.59(\mathrm{~m}, 1 \mathrm{H}), 7.52(\mathrm{~d}, J=5.6 \mathrm{~Hz}, 1 \mathrm{H}), 7.44-7.36(\mathrm{~m}, 1 \mathrm{H}), 7.29(\mathrm{t}, J=$ $7.8 \mathrm{~Hz}, 4 \mathrm{H}), 7.13-7.00$ (m, $6 \mathrm{H}) .{ }^{13} \mathrm{C} \mathrm{NMR}\left(101 \mathrm{MHz}, \mathrm{CDCl}_{3}\right) \delta 158.04,148.21,142.12,138.92$, 130.02, 129.29, 127.09, 127.05, 126.4 , 124.72, 123.79, 123.17, 118.56. ESI: Calcd. for $\mathrm{C}_{21} \mathrm{H}_{16} \mathrm{~N}_{2}[\mathrm{M}+\mathrm{H}]^{+}:$297.1392; found: 297.1379.<smiles>N#CCCN(c1ccccc1)c1nccc2ccccc12</smiles>

3-(isoquinolin-1-yl(phenyl)amino)propanenitrile (28c) The product is obtained as white soild (isolated yield: $94 \%):{ }^{1} \mathrm{H} \mathrm{NMR}\left(400 \mathrm{MHz}, \mathrm{CDCl}_{3}\right) \delta 8.21(\mathrm{~d}, J=5.1 \mathrm{~Hz}, 1 \mathrm{H}), 7.71(\mathrm{~d}, J=8.0$ $\mathrm{Hz}, 1 \mathrm{H}), 7.58(\mathrm{~d}, J=8.5 \mathrm{~Hz}, 1 \mathrm{H}), 7.49$ (t, $J=7.3 \mathrm{~Hz}, 1 \mathrm{H}), 7.36-7.16$ (m, $4 \mathrm{H}), 7.08-6.98$ (m, 3 $\mathrm{H}), 4.37(\mathrm{t}, J=6.6 \mathrm{~Hz}, 2 \mathrm{H}), 2.89(\mathrm{t}, J=6.5 \mathrm{~Hz}, 2 \mathrm{H}) .{ }^{13} \mathrm{C} \mathrm{NMR}\left(101 \mathrm{MHz}, \mathrm{CDCl}_{3}\right) \delta 156.06$, 148.99, 140.56, 138.39, 129.75, 129.63, 126.98, 126.63, 126.27, 124.10, 123.53, 122.24, 119.09, 117.03, 49.90, 16.67. ESI: Calcd. for $\mathrm{C}_{18} \mathrm{H}_{15} \mathrm{~N}_{3}[\mathrm{M}+\mathrm{Na}]^{+}$: 296.1164; found: 296.1153.<smiles>OCCN(c1ccccc1)c1nccc2ccccc12</smiles>

2-(isoquinolin-1-yl(phenyl)amino)ethanol (29c) The product is obtained as white soild (isolated yield: $90 \%):{ }^{1} \mathrm{H} \mathrm{NMR}\left(400 \mathrm{MHz}, \mathrm{CDCl}_{3}\right) \delta 8.16(\mathrm{~d}, J=5.8 \mathrm{~Hz}, 1 \mathrm{H}), 7.70$ (dd, $J=21.0$, $8.4 \mathrm{~Hz}, 2 \mathrm{H}), 7.57-7.45(\mathrm{~m}, 1 \mathrm{H}), 7.35$ (d, $J=5.8 \mathrm{~Hz}, 1 \mathrm{H}), 7.23$ (qd, J = 7.1, $1.4 \mathrm{~Hz}, 3 \mathrm{H}), 7.07$ (bs, $1 \mathrm{H}), 6.99$ (t, $J=7.4 \mathrm{~Hz}, 1 \mathrm{H}), 6.95-6.88(\mathrm{~m}, 2 \mathrm{H}), 4.33-4.24(\mathrm{~m}, 2 \mathrm{H}), 3.84-3.74(\mathrm{~m}, 2 \mathrm{H})$. ${ }^{13} \mathrm{C}$ NMR $\left(101 \mathrm{MHz}, \mathrm{CDCl}_{3}\right) \delta 157.84,147.84,139.79,138.81,130.13,129.66,127.18,127.15$, 126.64, 123.09, 122.93, 122.64, 117.46, 60.38, 55.87. ESI: Calcd. for $\mathrm{C}_{17} \mathrm{H}_{16} \mathrm{~N}_{2} \mathrm{O}[\mathrm{M}+\mathrm{Na}]^{+}$: 287.1160; found: 287.1149 . 
<smiles>COC(=O)CCN(c1ccccc1)c1nccc2ccccc12</smiles>

Methyl 3-(isoquinolin-1-yl(phenyl)amino)propanoate (30c) The product is obtained as white soild (isolated yield: $70 \%):{ }^{1} \mathrm{H} \mathrm{NMR}\left(400 \mathrm{MHz}, \mathrm{CDCl}_{3}\right) \delta 8.25(\mathrm{~d}, J=5.4 \mathrm{~Hz}, 1 \mathrm{H}), 7.70(\mathrm{~d}, J=$ $8.1 \mathrm{~Hz}, 1 \mathrm{H}), 7.59(\mathrm{~d}, J=8.5 \mathrm{~Hz}, 1 \mathrm{H}), 7.48(\mathrm{t}, J=7.5 \mathrm{~Hz}, 1 \mathrm{H}), 7.31(\mathrm{~d}, J=5.5 \mathrm{~Hz}, 1 \mathrm{H}), 7.22-$ $7.15(\mathrm{~m}, 3 \mathrm{H}), 7.06-6.82(\mathrm{~m}, 3 \mathrm{H}), 4.40(\mathrm{t}, J=6.9 \mathrm{~Hz}, 2 \mathrm{H}), 3.60(\mathrm{~s}, 3 \mathrm{H}), 2.83(\mathrm{t}, J=6.8 \mathrm{~Hz}, 2$ $\mathrm{H}) .{ }^{13} \mathrm{C} \mathrm{NMR}\left(101 \mathrm{MHz}, \mathrm{CDCl}_{3}\right) \delta 173.10,156.88,149.70,140.93,138.36,129.44,129.38$, 126.91, 126.72, 126.06, 122.91, 122.61, 116.73, 51.50, 49.48, 33.00. ESI: Calcd. for $\mathrm{C}_{19} \mathrm{H}_{18} \mathrm{~N}_{2} \mathrm{O}_{2}$ $[\mathrm{M}+\mathrm{H}]^{+}:$307.1447; found: 307.1431.<smiles>C=CCN(c1ccccc1)c1nccc2ccccc12</smiles>

$\boldsymbol{N}$-allyl- $\boldsymbol{N}$-phenylisoquinolin-1-amine (31c) The product is obtained as white soild (isolated yield: $82 \%$ ): ${ }^{1} \mathrm{H}$ NMR (400 MHz, $\left.\mathrm{CDCl}_{3}\right) \delta 8.28(\mathrm{~d}, J=5.6 \mathrm{~Hz}, 1 \mathrm{H}), 7.73(\mathrm{t}, J=7.3 \mathrm{~Hz}, 2 \mathrm{H})$, $7.52(\mathrm{t}, J=7.5 \mathrm{~Hz}, 1 \mathrm{H}), 7.34(\mathrm{~d}, J=5.7 \mathrm{~Hz}, 1 \mathrm{H}), 7.26(\mathrm{t}, J=7.7 \mathrm{~Hz}, 1 \mathrm{H}), 7.18(\mathrm{t}, J=7.5 \mathrm{~Hz}, 2$ $\mathrm{H}), 6.94(\mathrm{t}, J=7.3 \mathrm{~Hz}, 1 \mathrm{H}), 6.88(\mathrm{~d}, J=7.9 \mathrm{~Hz}, 2 \mathrm{H}), 6.12(\mathrm{ddt}, J=15.9,10.1,5.0 \mathrm{~Hz}, 1 \mathrm{H})$, $5.30(\mathrm{~d}, J=17.2 \mathrm{~Hz}, 1 \mathrm{H}), 5.10(\mathrm{~d}, J=10.3 \mathrm{~Hz}, 1 \mathrm{H}), 4.79(\mathrm{~d}, J=4.2 \mathrm{~Hz}, 2 \mathrm{H}) .{ }^{13} \mathrm{C} \mathrm{NMR}(101$ $\left.\mathrm{MHz}_{2} \mathrm{CDCl}_{3}\right) \delta 157.19,149.76,141.00,138.53,135.64,129.63,129.12,127.03,126.79,126.21$, 123.08, 122.06, 121.09, 116.92, 116.12, 55.76. ESI: Calcd. for $\mathrm{C}_{18} \mathrm{H}_{16} \mathrm{~N}_{2}[\mathrm{M}+\mathrm{H}]^{+}:$: 261.1392; found: 261.1381 .<smiles>C#CCCN(c1ccccc1)c1nccc2ccccc12</smiles>

$\boldsymbol{N}$-(but-3-yn-1-yl)- $\boldsymbol{N}$-phenylisoquinolin-1-amine (32c) The product is obtained as white soild (isolated yield: $73 \%):{ }^{1} \mathrm{H} \mathrm{NMR}\left(400 \mathrm{MHz}, \mathrm{CDCl}_{3}\right) \delta 8.27(\mathrm{~d}, J=5.6 \mathrm{~Hz}, 1 \mathrm{H}), 7.73(\mathrm{~d}, J=8.1$ $\mathrm{Hz}, 1 \mathrm{H}), 7.66(\mathrm{~d}, J=8.5 \mathrm{~Hz}, 1 \mathrm{H}), 7.51(\mathrm{t}, J=7.5 \mathrm{~Hz}, 1 \mathrm{H}), 7.34(\mathrm{~d}, J=5.6 \mathrm{~Hz}, 1 \mathrm{H}), 7.22(\mathrm{t}, J$ $=7.4 \mathrm{~Hz}, 3 \mathrm{H}), 7.04-6.89(\mathrm{~m}, 3 \mathrm{H}), 4.31(\mathrm{t}, J=7.2 \mathrm{~Hz}, 2 \mathrm{H}), 2.71(\mathrm{t}, J=6.0 \mathrm{~Hz}, 2 \mathrm{H}), 2.01(\mathrm{~s}, 1$ H). ${ }^{13} \mathrm{C} \mathrm{NMR}\left(101 \mathrm{MHz}, \mathrm{CDCl}_{3}\right) \delta 156.76,149.63,141.04,138.44,129.46,129.36,126.91$, 126.84, 126.05, 122.88, 122.71, 122.26, 116.78, 82.89, 69.50, 52.46, 18.09. ESI: Calcd. for $\mathrm{C}_{19} \mathrm{H}_{16} \mathrm{~N}_{2}[\mathrm{M}+\mathrm{H}]^{+}:$273.1392; found: 273.1379 .<smiles>c1ccc(Nc2nccc3ccccc23)cc1</smiles>

$\boldsymbol{N}$-phenylisoquinolin-1-amine (33c) The product is obtained as white soild (isolated yield: $89 \%$ ): ${ }^{1} \mathrm{H}$ NMR $\left(400 \mathrm{MHz}, \mathrm{CDCl}_{3}\right) \delta 8.09(\mathrm{~d}, J=5.8 \mathrm{~Hz}, 1 \mathrm{H}), 7.92(\mathrm{~d}, J=8.4 \mathrm{~Hz}, 1 \mathrm{H}), 7.74(\mathrm{~d}, J=$ $8.1 \mathrm{~Hz}, 1 \mathrm{H}), 7.69-7.61(\mathrm{~m}, 3 \mathrm{H}), 7.53(\mathrm{t}, J=7.6 \mathrm{~Hz}, 1 \mathrm{H}), 7.36(\mathrm{t}, J=7.8 \mathrm{~Hz}, 2 \mathrm{H}), 7.13(\mathrm{~d}, J=$ $5.8 \mathrm{~Hz}, 1 \mathrm{H}), 7.06(\mathrm{t}, J=7.4 \mathrm{~Hz}, 1 \mathrm{H}) .{ }^{13} \mathrm{C} \mathrm{NMR}\left(101 \mathrm{MHz}, \mathrm{CDCl}_{3}\right) \delta 152.26,140.82,140.45$, 137.50, 129.95, 129.03, 127.49, 126.52, 122.75, 121.52, 120.31, 118.85, 113.47. ESI: Calcd. for $\mathrm{C}_{15} \mathrm{H}_{12} \mathrm{~N}_{2}[\mathrm{M}+\mathrm{H}]^{+}:$221.1079; found: 221.1070. 
<smiles>Clc1ccc(Nc2nccc3ccccc23)cc1</smiles>

$\boldsymbol{N}$-(4-chlorophenyl)isoquinolin-1-amine (34c) The product is obtained as white soild (isolated yield: 90\%): ${ }^{1} \mathrm{H}$ NMR $\left(400 \mathrm{MHz}, \mathrm{CDCl}_{3}\right) \delta 8.08(\mathrm{~d}, J=5.8 \mathrm{~Hz}, 1 \mathrm{H}), 7.90(\mathrm{~d}, J=8.4 \mathrm{~Hz}, 1 \mathrm{H})$, $7.75(\mathrm{~d}, J=8.1 \mathrm{~Hz}, 1 \mathrm{H}), 7.64(\mathrm{dd}, J=17.3,8.2 \mathrm{~Hz}, 3 \mathrm{H}), 7.54(\mathrm{t}, J=7.6 \mathrm{~Hz}, 1 \mathrm{H}), 7.30(\mathrm{~d}, J=$ $8.8 \mathrm{~Hz}, 2 \mathrm{H}), 7.15(\mathrm{~d}, J=5.8 \mathrm{~Hz}, 1 \mathrm{H}) .{ }^{13} \mathrm{C} \mathrm{NMR}\left(101 \mathrm{MHz}, \mathrm{CDCl}_{3}\right) \delta 151.95,140.71,139.07$, 137.48, 130.05, 128.92, 127.55, 127.40, 126.66, 121.46, 121.33, 118.77, 113.84. ESI: Calcd. for $\mathrm{C}_{15} \mathrm{H}_{11} \mathrm{ClN}_{2}[\mathrm{M}+\mathrm{H}]^{+}:$255.0689; found: 255.0677 .<smiles>Brc1ccc(Nc2nccc3ccccc23)cc1</smiles>

$\boldsymbol{N}$-(4-bromophenyl)isoquinolin-1-amine (35c) The product is obtained as white soild (isolated yield: $93 \%):{ }^{1} \mathrm{H}$ NMR $\left(400 \mathrm{MHz}, \mathrm{CDCl}_{3}\right) \delta 8.08(\mathrm{~d}, J=5.8 \mathrm{~Hz}, 1 \mathrm{H}), 7.91(\mathrm{~d}, J=8.4 \mathrm{~Hz}, 1 \mathrm{H})$, $7.76(\mathrm{~d}, J=8.1 \mathrm{~Hz}, 1 \mathrm{H}), 7.66(\mathrm{t}, J=7.5 \mathrm{~Hz}, 1 \mathrm{H}), 7.57(\mathrm{~d}, J=8.5 \mathrm{~Hz}, 3 \mathrm{H}), 7.44(\mathrm{~d}, J=8.5 \mathrm{~Hz}$, $2 \mathrm{H}), 7.15(\mathrm{~d}, J=5.8 \mathrm{~Hz}, 1 \mathrm{H}) .{ }^{13} \mathrm{C} \mathrm{NMR}\left(101 \mathrm{MHz}, \mathrm{CDCl}_{3}\right) \delta 151.98,140.66,139.74,137.63$, $131.95,130.15,127.65,126.77,121.89,121.48,118.94,115.02,113.98$. ESI: Calcd. for $\mathrm{C}_{15} \mathrm{H}_{11} \mathrm{BrN}_{2}[\mathrm{M}+\mathrm{H}]^{+}:$299.0184; found: 299.0176 .<smiles>Cc1ccc(Nc2nccc3ccccc23)cc1</smiles>

$\boldsymbol{N}$-(p-tolyl)isoquinolin-1-amine (36c) The product is obtained as white solid (isolated yield: 89\%): ${ }^{1} \mathrm{H}$ NMR (400 MHz, $\left.\mathrm{CDCl}_{3}\right) \delta 8.05(\mathrm{~d}, J=5.8 \mathrm{~Hz}, 1 \mathrm{H}), 7.89$ (d, J=8.4 Hz, $\left.1 \mathrm{H}\right), 7.71$ (d, $J=8.1 \mathrm{~Hz}, 1 \mathrm{H}), 7.63-7.57(\mathrm{~m}, 1 \mathrm{H}), 7.50(\mathrm{dd}, J=8.4,2.4 \mathrm{~Hz}, 3 \mathrm{H}), 7.15(\mathrm{~d}, J=8.2 \mathrm{~Hz}, 2 \mathrm{H})$, $7.08(\mathrm{~d}, J=5.8 \mathrm{~Hz}, 1 \mathrm{H}), 2.32$ (s, $3 \mathrm{H}) .{ }^{13} \mathrm{C} \mathrm{NMR}\left(101 \mathrm{MHz}, \mathrm{CDCl}_{3}\right) \delta 152.69,140.99,137.81$, 137.49, 132.50, 129.86, 129.53, 127.40, 126.37, 121.59, 120.97, 118.78, 113.09, 20.87. ESI: Calcd. for $\mathrm{C}_{16} \mathrm{H}_{14} \mathrm{~N}_{2}[\mathrm{M}+\mathrm{H}]^{+}$: 235.1235; found: 235.1224 .<smiles>COc1ccc(Nc2nccc3ccccc23)cc1</smiles>

$\boldsymbol{N}$-(4-methoxyphenyl)isoquinolin-1-amine (37c) The product is obtained as white solid (isolated yield: 93\%): ${ }^{1} \mathrm{H} \mathrm{NMR}\left(400 \mathrm{MHz}, \mathrm{CDCl}_{3}\right) \delta 8.02(\mathrm{~d}, J=5.8 \mathrm{~Hz}, 1 \mathrm{H}), 7.85(\mathrm{~d}, J=8.4$ $\mathrm{Hz}, 1 \mathrm{H}), 7.68(\mathrm{~d}, J=8.1 \mathrm{~Hz}, 1 \mathrm{H}), 7.59(\mathrm{~d}, J=7.3 \mathrm{~Hz}, 1 \mathrm{H}), 7.47(\mathrm{t}, J=8.7 \mathrm{~Hz}, 3 \mathrm{H}), 7.03(\mathrm{~d}, J$ $=5.8 \mathrm{~Hz}, 1 \mathrm{H}), 6.87(\mathrm{~d}, J=8.8 \mathrm{~Hz}, 2 \mathrm{H}), 3.76(\mathrm{~s}, 3 \mathrm{H}) .{ }^{13} \mathrm{C} \mathrm{NMR}\left(101 \mathrm{MHz}, \mathrm{CDCl}_{3}\right) \delta 155.81$, 153.07, 141.09, 137.45, 133.45, 129.83, 127.35, 126.30, 123.20, 121.57, 118.58, 114.33, 112.74, 55.57. ESI: Calcd. for $\mathrm{C}_{16} \mathrm{H}_{14} \mathrm{~N}_{2} \mathrm{O}[\mathrm{M}+\mathrm{H}]^{+}:$: 251.1184; found: 251.1174 .<smiles>COc1cccc(Nc2nccc3ccccc23)c1</smiles> 
$\mathrm{N}$-(3-methoxyphenyl)isoquinolin-1-amine (38c) The product is obtained as white soild (isolated yield: $90 \%):{ }^{1} \mathrm{H}$ NMR $\left(400 \mathrm{MHz}, \mathrm{CDCl}_{3}\right) \delta 8.10(\mathrm{~d}, J=5.8 \mathrm{~Hz}, 1 \mathrm{H}), 7.92(\mathrm{~d}, J=8.4$ $\mathrm{Hz}, 1 \mathrm{H}), 7.74(\mathrm{~d}, J=8.1 \mathrm{~Hz}, 1 \mathrm{H}), 7.67-7.58(\mathrm{~m}, 1 \mathrm{H}), 7.57-7.47(\mathrm{~m}, 1 \mathrm{H}), 7.43(\mathrm{~s}, 1 \mathrm{H}), 7.24(\mathrm{~d}$, $J=8.3 \mathrm{~Hz}, 1 \mathrm{H}), 7.18-7.09(\mathrm{~m}, 2 \mathrm{H}), 6.66-6.48(\mathrm{~m}, 1 \mathrm{H}), 3.83(\mathrm{~s}, 3 \mathrm{H}) .{ }^{13} \mathrm{C}$ NMR $(101 \mathrm{MHz}$, $\left.\mathrm{CDCl}_{3}\right) \delta 160.31,152.18,141.79,140.85,137.49,129.94,129.64,127.47,126.53,121.53$, 118.94, 113.57, 112.58, 108.12, 106.18, 55.30. ESI: Calcd. for $\mathrm{C}_{16} \mathrm{H}_{14} \mathrm{~N}_{2} \mathrm{O}[\mathrm{M}+\mathrm{H}]^{+}$: 251.1184; found: 251.1173 .

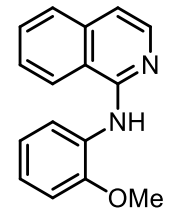

$\mathrm{N}$-(2-methoxyphenyl)isoquinolin-1-amine (39c) The product is obtained as white soild (isolated yield: $92 \%):{ }^{1} \mathrm{H}$ NMR $\left(400 \mathrm{MHz}, \mathrm{CDCl}_{3}\right) \delta 8.74(\mathrm{~d}, J=7.7 \mathrm{~Hz}, 1 \mathrm{H}), 8.12(\mathrm{~d}, J=5.8$ $\mathrm{Hz}, 1 \mathrm{H}), 8.06-7.89(\mathrm{~m}, 2 \mathrm{H}), 7.72(\mathrm{~d}, J=8.1 \mathrm{~Hz}, 1 \mathrm{H}), 7.62(\mathrm{t}, J=7.5 \mathrm{~Hz}, 1 \mathrm{H}), 7.54(\mathrm{t}, J=7.6$ $\mathrm{Hz}, 1 \mathrm{H}), 7.14-6.84(\mathrm{~m}, 4 \mathrm{H}), 3.96$ (s, $3 \mathrm{H}) .{ }^{13} \mathrm{C} \mathrm{NMR}\left(101 \mathrm{MHz}, \mathrm{CDCl}_{3}\right) \delta 152.03,148.20$, 140.94, 137.37, 130.20, 129.77, 127.41, 126.47, 121.51, 121.37, 121.17, 119.36, 118.90, 113.01, 109.91, 55.94. ESI: Calcd. for $\mathrm{C}_{16} \mathrm{H}_{14} \mathrm{~N}_{2} \mathrm{O}[\mathrm{M}+\mathrm{H}]^{+}:$: 251.1184; found: 251.1171 .<smiles>Cc1cc(C)cc(Nc2nccc3ccccc23)c1</smiles>

$\mathrm{N}$-(3,5-dimethylphenyl)isoquinolin-1-amine (40c) The product is obtained as white soild (isolated yield: $89 \%):{ }^{1} \mathrm{H}$ NMR $\left(400 \mathrm{MHz}, \mathrm{CDCl}_{3}\right) \delta 8.09(\mathrm{~d}, J=5.7 \mathrm{~Hz}, 1 \mathrm{H}), 7.90(\mathrm{~d}, J=8.4$ $\mathrm{Hz}, 1 \mathrm{H}), 7.74(\mathrm{~d}, J=8.1 \mathrm{~Hz}, 1 \mathrm{H}), 7.63(\mathrm{t}, J=7.5 \mathrm{~Hz}, 1 \mathrm{H}), 7.52(\mathrm{t}, J=7.6 \mathrm{~Hz}, 1 \mathrm{H}), 7.30-7.24$ $(\mathrm{m}, 2 \mathrm{H}), 7.10(\mathrm{~d}, J=5.7 \mathrm{~Hz}, 1 \mathrm{H}), 6.71(\mathrm{~s}, 1 \mathrm{H}), 2.32(\mathrm{~s}, 6 \mathrm{H}) .{ }^{13} \mathrm{C} \mathrm{NMR}\left(101 \mathrm{MHz}, \mathrm{CDCl}_{3}\right) \delta$ $152.51,140.87,140.30,138.64,137.51,129.92,127.43,126.43,124.75,121.65,118.95,118.22$, 113.23, 21.51. ESI: Calcd. for $\mathrm{C}_{17} \mathrm{H}_{16} \mathrm{~N}_{2}$ [M+H] $]^{+}$: 249.1392; found: 249.1382 .<smiles></smiles>

$\mathbf{N}$-(dibenzo[b,d]furan-3-yl)isoquinolin-1-amine (41c) The product is obtained as white soild (isolated yield: 63\%): ${ }^{1} \mathrm{H}$ NMR $\left(400 \mathrm{MHz}, \mathrm{CDCl}_{3}\right) \delta 8.27(\mathrm{~s}, 1 \mathrm{H}), 8.09-8.03(\mathrm{~m},, 2 \mathrm{H}), 7.92-$ $7.81(\mathrm{~m}, 2 \mathrm{H}), 7.73(\mathrm{~d}, J=8.1 \mathrm{~Hz}, 1 \mathrm{H}), 7.66(\mathrm{t}, J=7.4 \mathrm{~Hz}, 1 \mathrm{H}), 7.53(\mathrm{dd}, J=19.5,7.8 \mathrm{~Hz}, 2 \mathrm{H})$, $7.40(\mathrm{dd}, J=20.5,8.1 \mathrm{~Hz}, 2 \mathrm{H}), 7.31(\mathrm{t}, J=7.4 \mathrm{~Hz}, 1 \mathrm{H}), 7.11(\mathrm{~d}, J=5.5 \mathrm{~Hz}, 1 \mathrm{H}) .{ }^{13} \mathrm{C}$ NMR $\left(101 \mathrm{MHz}, \mathrm{CDCl}_{3}\right) \delta 157.11,156.52,151.96,140.10,139.93,137.54,130.24,127.58,126.76$, $126.08,124.43,122.67,121.65,120.67,119.96,119.25,118.86,115.77,113.78,111.46,103.61$. ESI: Calcd. for $\mathrm{C}_{21} \mathrm{H}_{14} \mathrm{~N}_{2} \mathrm{O}$ [M+H] $]^{+}$: 311.1184; found: 311.1173.<smiles>CCN(CC)c1nccc2ccccc12</smiles>

$\mathrm{N}, \mathbf{N}$-diethylisoquinolin-1-amine (42c) The product is obtained as white soild (isolated yield: $33 \%):{ }^{1} \mathrm{H}$ NMR $\left(400 \mathrm{MHz}, \mathrm{CDCl}_{3}\right) \delta 8.16-8.10(\mathrm{~m}, 2 \mathrm{H}), 7.72(\mathrm{~d}, J=8.1 \mathrm{~Hz}, 1 \mathrm{H}), 7.58(\mathrm{t}, J=$ 
$7.4 \mathrm{~Hz}, 1 \mathrm{H}), 7.48(\mathrm{t}, J=7.6 \mathrm{~Hz}, 1 \mathrm{H}), 7.18(\mathrm{~d}, J=5.7 \mathrm{~Hz}, 1 \mathrm{H}), 3.48(\mathrm{q}, J=7.0 \mathrm{~Hz}, 4 \mathrm{H}), 1.20(\mathrm{t}$, $J=7.0 \mathrm{~Hz}, 6 \mathrm{H}) .{ }^{13} \mathrm{C} \mathrm{NMR}\left(101 \mathrm{MHz}, \mathrm{CDCl}_{3}\right) \delta 161.18,140.52,138.31,129.40,126.91,125.86$, 125.63, 122.94, 114.85, 46.11, 13.08. ESI: Calcd. for $\mathrm{C}_{17} \mathrm{H}_{16} \mathrm{~N}_{3}[\mathrm{M}+\mathrm{H}]^{+}: 201.1392$; found: 201.1388 .<smiles>CN(c1ccccc1)c1nccc2ccccc12</smiles>

$\mathrm{N}$-benzyl- $\mathrm{N}$-methylisoquinolin-1-amine (43c) The product is obtained as white soild (isolated yield: $37 \%):{ }^{1} \mathrm{H}$ NMR (400 MHz, $\left.\mathrm{CDCl}_{3}\right) \delta 8.20-8.12(\mathrm{~m}, 2 \mathrm{H}), 7.75(\mathrm{~d}, J=8.1 \mathrm{~Hz}, 1 \mathrm{H}), 7.60(\mathrm{t}$, $J=7.5 \mathrm{~Hz}, 1 \mathrm{H}), 7.51-7.29(\mathrm{~m}, 6 \mathrm{H}), 7.23(\mathrm{~d}, J=5.7 \mathrm{~Hz}, 1 \mathrm{H}), 4.64(\mathrm{~s}, 2 \mathrm{H}), 3.02(\mathrm{~s}, 3 \mathrm{H}) .{ }^{13} \mathrm{C}$ NMR $\left(101 \mathrm{MHz}, \mathrm{CDCl}_{3}\right) \delta 161.82,140.55,138.82,138.38,129.57,128.59,127.66,127.08$, 125.86, 125.60, 121.60, 115.07, 59.23, 40.05.ESI: Calcd.for $\mathrm{C}_{17} \mathrm{H}_{16} \mathrm{~N}_{2}[\mathrm{M}+\mathrm{H}]^{+}$: 249.1392; found: 249.1386 .<smiles>c1ccc2c(c1)ncn2C1CCC1</smiles>

1-(azetidin-1-yl)isoquinoline (44c) The product is obtained as white soild (isolated yield: 48\%): ${ }^{1} \mathrm{H}$ NMR $\left(400 \mathrm{MHz}, \mathrm{CDCl}_{3}\right) \delta 8.02(\mathrm{~d}, J=5.8 \mathrm{~Hz}, 1 \mathrm{H}), 7.93(\mathrm{~d}, J=8.4 \mathrm{~Hz}, 1 \mathrm{H}), 7.67(\mathrm{~d}, J=$ $8.1 \mathrm{~Hz}, 1 \mathrm{H}), 7.55(\mathrm{t}, J=7.5 \mathrm{~Hz}, 1 \mathrm{H}), 7.40(\mathrm{t}, J=7.6 \mathrm{~Hz}, 1 \mathrm{H}), 6.97(\mathrm{~d}, J=5.8 \mathrm{~Hz}, 1 \mathrm{H}), 4.46(\mathrm{t}$, $J=7.5 \mathrm{~Hz}, 4 \mathrm{H}), 2.46(\mathrm{p}, J=7.5 \mathrm{~Hz}, 2 \mathrm{H}) .{ }^{13} \mathrm{C}$ NMR $\left(101 \mathrm{MHz}, \mathrm{CDCl}_{3}\right) \delta 158.71,140.95$, $137.98,129.57,126.87,125.11,124.86,119.03,111.73,53.96,17.41$. ESI: Calcd. for $\mathrm{C}_{12} \mathrm{H}_{12} \mathrm{~N}_{2}$ $[\mathrm{M}+\mathrm{H}]^{+}:$185.1079; found: 185.1075 .<smiles>c1ccc2c(N3CCCC3)nccc2c1</smiles>

1-(pyrrolidin-1-yl)isoquinoline (45c) The product is obtained as white soild (isolated yield: 75\%): ${ }^{1} \mathrm{H}$ NMR $\left(400 \mathrm{MHz}, \mathrm{CDCl}_{3}\right) \delta 8.20(\mathrm{~d}, J=8.6 \mathrm{~Hz}, 1 \mathrm{H}), 7.99(\mathrm{~d}, J=5.7 \mathrm{~Hz}, 1 \mathrm{H}), 7.65(\mathrm{~d}$, $J=8.1 \mathrm{~Hz}, 1 \mathrm{H}), 7.53(\mathrm{t}, J=7.5 \mathrm{~Hz}, 1 \mathrm{H}), 7.38(\mathrm{t}, J=7.7 \mathrm{~Hz}, 1 \mathrm{H}), 6.96(\mathrm{~d}, J=5.7 \mathrm{~Hz}, 1 \mathrm{H})$, $3.84(\mathrm{t}, J=6.3 \mathrm{~Hz}, 4 \mathrm{H}), 2.03-1.96(\mathrm{~m}, 4 \mathrm{H}) .{ }^{13} \mathrm{C} \mathrm{NMR}\left(101 \mathrm{MHz}, \mathrm{CDCl}_{3}\right) \delta 157.96,140.78$, $138.79,129.13,126.64,126.19,124.35,120.14,111.62,51.53,25.98$. ESI: Calcd. for $\mathrm{C}_{13} \mathrm{H}_{14} \mathrm{~N}_{2}$ $[\mathrm{M}+\mathrm{H}]^{+}:$199.1235; found: 199.1230 .<smiles></smiles>

4-(isoquinolin-1-yl)morpholine (46c) The product is obtained as white soild (isolated yield: 54\%): ${ }^{1} \mathrm{H}$ NMR $\left(400 \mathrm{MHz}, \mathrm{CDCl}_{3}\right) 8.16(\mathrm{~d}, J=5.8 \mathrm{~Hz}, 1 \mathrm{H}), 8.11(\mathrm{~d}, J=8.4 \mathrm{~Hz}, 1 \mathrm{H}), 7.77(\mathrm{~d}, J$ $=8.1 \mathrm{~Hz}, 1 \mathrm{H}), 7.63(\mathrm{t}, J=7.5 \mathrm{~Hz}, 1 \mathrm{H}), 7.53(\mathrm{t}, J=7.6 \mathrm{~Hz}, 1 \mathrm{H}), 7.28(\mathrm{~d}, J=5.8 \mathrm{~Hz}, 1 \mathrm{H}), 4.02$ $-3.92(\mathrm{~m}, 4 \mathrm{H}), 3.47-3.38$ (m, $4 \mathrm{H}) .{ }^{13} \mathrm{C}$ NMR $\left(101 \mathrm{MHz}, \mathrm{CDCl}_{3}\right) \delta 160.48,139.96,137.67$, 129.19, 126.62, 125.62, 124.80, 121.09, 115.54, 66.51, 51.33. ESI: Calcd. for $\mathrm{C}_{13} \mathrm{H}_{14} \mathrm{~N}_{2} \mathrm{O}$ $[\mathrm{M}+\mathrm{H}]^{+}:$215.1184; found: 215.1180 . 
<smiles></smiles>

1-(4-methylpiperidin-1-yl)isoquinoline (47c) The product is obtained as white soild (isolated yield: $47 \%):{ }^{1} \mathrm{H}$ NMR $\left(400 \mathrm{MHz}, \mathrm{CDCl}_{3}\right) \delta 8.13(\mathrm{~d}, J=5.8 \mathrm{~Hz}, 1 \mathrm{H}), 8.09(\mathrm{~d}, J=8.4 \mathrm{~Hz}, 1 \mathrm{H})$, $7.73(\mathrm{~d}, J=8.1 \mathrm{~Hz}, 1 \mathrm{H}), 7.59(\mathrm{t}, J=7.5 \mathrm{~Hz}, 1 \mathrm{H}), 7.49(\mathrm{t}, J=7.6 \mathrm{~Hz}, 1 \mathrm{H}), 7.21(\mathrm{~d}, J=5.8 \mathrm{~Hz}, 1$ H), $3.80(\mathrm{~d}, J=12.8 \mathrm{~Hz}, 2 \mathrm{H}), 2.96(\mathrm{t}, J=12.3 \mathrm{~Hz}, 2 \mathrm{H}), 1.83(\mathrm{~d}, J=12.6 \mathrm{~Hz}, 2 \mathrm{H}), 1.73-1.47$ $(\mathrm{m}, 3 \mathrm{H}), 1.06(\mathrm{~d}, J=6.3 \mathrm{~Hz}, 3 \mathrm{H}) .{ }^{13} \mathrm{C} \mathrm{NMR}\left(101 \mathrm{MHz}, \mathrm{CDCl}_{3}\right) \delta 162.25,140.62,138.12$, 129.58, 126.98, 125.91, 125.85, 122.09, 115.37, 52.07, 34.65, 31.30, 22.05. ESI: Calcd. for $\mathrm{C}_{15} \mathrm{H}_{18} \mathrm{~N}_{2}[\mathrm{M}+\mathrm{H}]^{+}:$:227.1548; found: 227.1543 .<smiles>c1ccc(C2CCN(c3nccc4ccccc34)CC2)cc1</smiles>

1-(4-phenylpiperidin-1-yl)isoquinoline (48c) The product is obtained as white soild (isolated yield: 35\%): ${ }^{1} \mathrm{H}$ NMR (400 MHz, $\left.\mathrm{CDCl}_{3}\right) \delta 8.21-8.12(\mathrm{~m}, 2 \mathrm{H}), 7.76(\mathrm{~d}, J=8.1 \mathrm{~Hz}, 1 \mathrm{H}), 7.62(\mathrm{t}$, $J=7.5 \mathrm{~Hz}, 1 \mathrm{H}), 7.53(\mathrm{t}, J=7.6 \mathrm{~Hz}, 1 \mathrm{H}), 7.40-7.32(\mathrm{~m}, 4 \mathrm{H}), 7.28-7.23(\mathrm{q}, J=4.2 \mathrm{~Hz}, 2 \mathrm{H})$, $3.97(\mathrm{~d}, J=12.7 \mathrm{~Hz}, 2 \mathrm{H}), 3.10(\mathrm{td}, J=12.5,2.8 \mathrm{~Hz}, 2 \mathrm{H}), 2.88-2.72$ (m, $1 \mathrm{H}), 2.17-1.99$ (m, 4 $\mathrm{H}) .{ }^{13} \mathrm{C} \mathrm{NMR}\left(101 \mathrm{MHz}, \mathrm{CDCl}_{3}\right) \delta 162.10,146.23,140.74,138.16,129.64,128.50,127.08$, 126.94, 126.28, 126.06, 125.74, 122.08, 115.67, 52.46, 43.03, 33.77. ESI: Calcd. for $\mathrm{C}_{20} \mathrm{H}_{20} \mathrm{~N}_{2}$ $[\mathrm{M}+\mathrm{H}]^{+}:$289.1705; found: 289.1698 .<smiles>CCOC(=O)C1CCN(c2nccc3ccccc23)CC1</smiles>

Ethyl 1-(isoquinolin-1-yl)piperidine-4-carboxylate (49c) The product is obtained as white soild (isolated yield: $43 \%):{ }^{1} \mathrm{H} \mathrm{NMR}\left(400 \mathrm{MHz}, \mathrm{CDCl}_{3}\right) \delta 8.13(\mathrm{~d}, J=5.8 \mathrm{~Hz}, 1 \mathrm{H}), 8.08(\mathrm{~d}, J=$ $8.4 \mathrm{~Hz}, 1 \mathrm{H}), 7.74(\mathrm{~d}, J=8.1 \mathrm{~Hz}, 1 \mathrm{H}), 7.61(\mathrm{t}, J=7.5 \mathrm{~Hz}, 1 \mathrm{H}), 7.51(\mathrm{t}, J=7.6 \mathrm{~Hz}, 1 \mathrm{H}), 7.24(\mathrm{~d}$, $J=5.7 \mathrm{~Hz}, 1 \mathrm{H}), 4.19(\mathrm{q}, J=7.1 \mathrm{~Hz}, 2 \mathrm{H}), 3.81(\mathrm{~d}, J=12.8 \mathrm{~Hz}, 2 \mathrm{H}), 3.11-2.94(\mathrm{~m}, 2 \mathrm{H}), 2.56$ $(\mathrm{tt}, J=10.4,4.5 \mathrm{~Hz}, 1 \mathrm{H}), 2.09(\mathrm{qd}, J=12.0,10.9,3.4 \mathrm{~Hz}, 4 \mathrm{H}), 1.30(\mathrm{t}, J=7.1 \mathrm{~Hz}, 3 \mathrm{H}) .{ }^{13} \mathrm{C}$ $\operatorname{NMR}\left(101 \mathrm{MHz}, \mathrm{CDCl}_{3}\right) \delta 175.04,161.86,140.57,138.11,129.72,127.06,126.18,125.60$, 122.03, 115.88, 60.47, 51.23, 41.60, 28.60, 14.28. ESI: Calcd. for $\mathrm{C}_{17} \mathrm{H}_{20} \mathrm{~N}_{2} \mathrm{O}_{2}[\mathrm{M}+\mathrm{H}]^{+}$:

285.1603; found: 285.1597.<smiles>NCCN(c1ccccc1)c1nccc2ccccc12</smiles>

$\boldsymbol{N}^{\mathbf{1}}$-(isoquinolin-1-yl)- $\boldsymbol{N}^{\mathbf{1}}$-phenylethane-1,2-diamine (50c) The product is obtained as white soild (isolated yield: $78 \%):{ }^{1} \mathrm{H} \mathrm{NMR}\left(400 \mathrm{MHz}, \mathrm{CDCl}_{3}\right) \delta 7.98(\mathrm{~d}, J=5.8 \mathrm{~Hz}, 1 \mathrm{H}), 7.79(\mathrm{~d}, J=$ $8.3 \mathrm{~Hz}, 1 \mathrm{H}), 7.68(\mathrm{~d}, J=8.0 \mathrm{~Hz}, 1 \mathrm{H}), 7.60(\mathrm{t}, J=7.4 \mathrm{~Hz}, 1 \mathrm{H}), 7.46(\mathrm{t}, J=7.6 \mathrm{~Hz}, 1 \mathrm{H}), 7.16$ (t, $J=7.4 \mathrm{~Hz}, 2 \mathrm{H}), 6.96(\mathrm{~d}, J=5.8 \mathrm{~Hz}, 1 \mathrm{H}), 6.75-6.62(\mathrm{~m}, 3 \mathrm{H}), 5.86(\mathrm{bs}, 1 \mathrm{H}), 3.92$ (d, $J=5.1$ 
$\mathrm{Hz}, 2 \mathrm{H}), 3.51(\mathrm{t}, J=5.3 \mathrm{~Hz}, 2 \mathrm{H}) .{ }^{13} \mathrm{C} \mathrm{NMR}\left(101 \mathrm{MHz}, \mathrm{CDCl}_{3}\right) \delta 155.23,148.52,140.25$, 137.27, 130.22, 129.46, 127.40, 126.34, 121.87, 118.38, 117.74, 113.16, 111.49, 44.44, 41.75. ESI: Calcd. for $\mathrm{C}_{17} \mathrm{H}_{17} \mathrm{~N}_{3}[\mathrm{M}+\mathrm{H}]^{+}:$264.1501; found: 264.1489 .<smiles>c1ccc(N(c2nccc3ccccc23)C2CCNCC2)cc1</smiles>

$N$-phenyl- $N$-(piperidin-4-yl)isoquinolin-1-amine (51c) The product is obtained as white soild (isolated yield: 60\%): ${ }^{1} \mathrm{H}$ NMR $\left(400 \mathrm{MHz}, \mathrm{CDCl}_{3}\right) \delta 9.60-9.15(\mathrm{~m}, 1 \mathrm{H}), 8.25(\mathrm{~d}, J=4.9 \mathrm{~Hz}, 1$ H), $7.77(\mathrm{~d}, J=8.3 \mathrm{~Hz}, 1 \mathrm{H}), 7.68(\mathrm{~d}, J=7.9 \mathrm{~Hz}, 1 \mathrm{H}), 7.47(\mathrm{t}, J=7.1 \mathrm{~Hz}, 1 \mathrm{H}), 7.33(\mathrm{~d}, J=4.8$ $\mathrm{Hz}, 1 \mathrm{H}), 7.25-7.16(\mathrm{~m}, 3 \mathrm{H}), 7.08-6.94(\mathrm{~m}, 3 \mathrm{H}), 4.75-4.65(\mathrm{~m}, 1 \mathrm{H}), 3.56(\mathrm{~d}, J=11.4 \mathrm{~Hz}, 2 \mathrm{H})$, $3.03(\mathrm{t}, J=10.1 \mathrm{~Hz}, 2 \mathrm{H}), 2.32-2.06(\mathrm{~m}, 4 \mathrm{H}) .{ }^{13} \mathrm{C} \mathrm{NMR}\left(101 \mathrm{MHz}, \mathrm{CDCl}_{3}\right) \delta 157.73,147.14$, 140.69, 138.67, 129.64, 129.52, 126.99, 126.60, 126.53, 126.17, 124.78, 124.11, 117.49, 55.80, 44.18, 28.30. ESI: Calcd. for $\mathrm{C}_{20} \mathrm{H}_{21} \mathrm{~N}_{3}[\mathrm{M}+\mathrm{H}]^{+}$: 304.1814; found: 304.1799.<smiles>NCCc1ccc(Nc2nccc3ccccc23)cc1</smiles>

$\mathrm{N}$-(4-(2-aminoethyl)phenyl)isoquinolin-1-amine (52c) The product is obtained as white soild (isolated yield: $75 \%):{ }^{1} \mathrm{H} \mathrm{NMR}\left(400 \mathrm{MHz}, \mathrm{CDCl}_{3}\right) \delta 8.07(\mathrm{~d}, J=5.8 \mathrm{~Hz}, 1 \mathrm{H}), 7.92(\mathrm{~d}, J=8.4$ $\mathrm{Hz}, 1 \mathrm{H}), 7.72(\mathrm{~d}, J=8.1 \mathrm{~Hz}, 1 \mathrm{H}), 7.69-7.45(\mathrm{~m}, 4 \mathrm{H}), 7.24-7.14(\mathrm{~m}, 3 \mathrm{H}), 7.10(\mathrm{~d}, J=5.8 \mathrm{~Hz}$, $1 \mathrm{H}), 3.00-2.89(\mathrm{~m}, 2 \mathrm{H}), 2.71(\mathrm{t}, J=6.8 \mathrm{~Hz}, 2 \mathrm{H}), 1.38(\mathrm{~b}, 2 \mathrm{H}) .{ }^{13} \mathrm{C}$ NMR $\left(101 \mathrm{MHz}, \mathrm{CDCl}_{3}\right) \delta$ 152.46, 141.01, 138.58, 137.46, 134.17, 129.87, 129.35, 127.41, 126.41, 121.51, 120.74, 118.80, 113.21, 43.66, 39.53. ESI: Calcd. for $\mathrm{C}_{17} \mathrm{H}_{17} \mathrm{~N}_{3}[\mathrm{M}+\mathrm{H}]^{+}$: 264.1501; found: 264.1483.<smiles>Nc1ccc(Nc2nccc3ccccc23)cc1</smiles>

$\boldsymbol{N}^{\mathbf{1}}$-(isoquinolin-1-yl)benzene-1,4-diamine (53c) The product is obtained as white soild (isolated yield: $68 \%):{ }^{1} \mathrm{H} \mathrm{NMR}\left(400 \mathrm{MHz}, \mathrm{CDCl}_{3}\right) \delta 8.01(\mathrm{~d}, J=5.8 \mathrm{~Hz}, 1 \mathrm{H}), 7.90(\mathrm{~d}, J=8.3$ $\mathrm{Hz}, 1 \mathrm{H}), 7.72(\mathrm{~d}, J=8.1 \mathrm{~Hz}, 1 \mathrm{H}), 7.62(\mathrm{t}, J=7.5 \mathrm{~Hz}, 1 \mathrm{H}), 7.51(\mathrm{t}, J=7.6 \mathrm{~Hz}, 1 \mathrm{H}), 7.38(\mathrm{~d}, J$ $=8.4 \mathrm{~Hz}, 2 \mathrm{H}), 7.04(\mathrm{~d}, J=5.8 \mathrm{~Hz}, 1 \mathrm{H}), 6.72(\mathrm{~d}, J=8.5 \mathrm{~Hz}, 2 \mathrm{H}), 3.56(\mathrm{bs}, 2 \mathrm{H}) .{ }^{13} \mathrm{C} \mathrm{NMR}(101$ $\left.\mathrm{MHz}_{\mathrm{CDCl}}\right) \delta 153.28,142.68,141.13,137.47,131.64,129.79,127.35,126.20,123.62,121.57$, 118.49 , 115.82, 112.38. ESI: Calcd. for $\mathrm{C}_{15} \mathrm{H}_{13} \mathrm{~N}_{3}[\mathrm{M}+\mathrm{H}]^{+}:$236.1188; found: 236.1177.<smiles>c1ccc2c(Nc3ccc(CN4CCOCC4)cc3)nccc2c1</smiles>

$\mathrm{N}$-(4-(morpholinomethyl)phenyl)isoquinolin-1-amine (54c) The product is obtained as white soild (isolated yield: $74 \%):{ }^{1} \mathrm{H}$ NMR $\left(400 \mathrm{MHz}, \mathrm{CDCl}_{3}\right) \delta 8.08(\mathrm{~d}, J=5.5 \mathrm{~Hz}, 1 \mathrm{H}), 7.91(\mathrm{~d}, J=$ $8.3 \mathrm{~Hz}, 1 \mathrm{H}), 7.72(\mathrm{~d}, J=8.1 \mathrm{~Hz}, 1 \mathrm{H}), 7.62(\mathrm{t}, J=6.6 \mathrm{~Hz}, 3 \mathrm{H}), 7.51$ (t, $J=7.6 \mathrm{~Hz}, 1 \mathrm{H}), 7.29$ (d, $J=7.6 \mathrm{~Hz}, 2 \mathrm{H}), 7.20(\mathrm{bs}, 1 \mathrm{H}), 7.11(\mathrm{~d}, J=5.6 \mathrm{~Hz}, 1 \mathrm{H}), 3.70(\mathrm{~s}, 4 \mathrm{H}), 3.46(\mathrm{~s}, 2 \mathrm{H}), 2.45$ (s, 4 $\mathrm{H}) .{ }^{13} \mathrm{C} \mathrm{NMR}\left(101 \mathrm{MHz}, \mathrm{CDCl}_{3}\right) \delta 152.30,140.95,139.54,137.47,131.74,129.91,127.44$, 126.47, 121.49, 120.16, 118.83, 113.37, 67.02, 63.03, 53.57. ESI: Calcd. for $\mathrm{C}_{20} \mathrm{H}_{21} \mathrm{~N}_{3} \mathrm{O}[\mathrm{M}+\mathrm{H}]^{+}$: 320.1763 ; found:320.1747. 
<smiles>NC1CCN(c2nccc3ccccc23)CC1</smiles>

1-(isoquinolin-1-yl)piperidin-4-amine (55c) The product is obtained as white soild (isolated yield: $29 \%):{ }^{1} \mathrm{H}$ NMR $\left(400 \mathrm{MHz}, \mathrm{CDCl}_{3}\right) \delta 8.10(\mathrm{~d}, J=5.7 \mathrm{~Hz}, 1 \mathrm{H}), 8.05(\mathrm{~d}, J=8.3 \mathrm{~Hz}, 1 \mathrm{H})$, $7.71(\mathrm{~d}, J=8.2 \mathrm{~Hz}, 1 \mathrm{H}), 7.57(\mathrm{t}, J=7.4 \mathrm{~Hz}, 1 \mathrm{H}), 7.48(\mathrm{t}, J=7.6 \mathrm{~Hz}, 1 \mathrm{H}), 7.21(\mathrm{~d}, J=5.8 \mathrm{~Hz}, 1$ H), 4.29 (bs H), 3.80 (d, $J=12.5 \mathrm{~Hz}, 2 \mathrm{H}), 3.12(\mathrm{t}, J=10.3 \mathrm{~Hz}, 1 \mathrm{H}), 3.01(\mathrm{t}, J=11.9 \mathrm{~Hz}, 2 \mathrm{H})$, $2.13(\mathrm{~d}, J=9.9 \mathrm{~Hz}, 2 \mathrm{H}), 1.86(\mathrm{q}, J=10.6,9.6 \mathrm{~Hz}, 2 \mathrm{H}) .{ }^{13} \mathrm{C} \mathrm{NMR}\left(101 \mathrm{MHz}, \mathrm{CDCl}_{3}\right) \delta 161.61$, 140.62, 138.07, 129.69, 127.05, 126.20, 125.54, 121.95, 115.95, 50.29, 49.31, 34.16. ESI: Calcd. for $\mathrm{C}_{14} \mathrm{H}_{17} \mathrm{~N}_{3}[\mathrm{M}+\mathrm{H}]^{+}:$228.1501; found: 228.1496 .<smiles>NC(=O)Cc1ccc(Nc2nccc3ccccc23)cc1</smiles>

2-(4-(isoquinolin-1-ylamino)phenyl)acetamide (56c) The product is obtained as white soild (isolated yield: 64\%): ${ }^{1} \mathrm{H}$ NMR $\left(400 \mathrm{MHz}\right.$, Methanol- $\left.d_{4}\right) \delta 8.32(\mathrm{~d}, J=8.4 \mathrm{~Hz}, 1 \mathrm{H}), 7.85-7.65$ $(\mathrm{m}, 3 \mathrm{H}), 7.62-7.50(\mathrm{~m}, 3 \mathrm{H}), 7.30(\mathrm{~d}, J=8.0 \mathrm{~Hz}, 2 \mathrm{H}), 7.11(\mathrm{~d}, J=5.7 \mathrm{~Hz}, 1 \mathrm{H}), 4.88(\mathrm{~s}, 2 \mathrm{H})$ $3.51(\mathrm{~s}, 2 \mathrm{H}) .{ }^{13} \mathrm{C}$ NMR $\left(101 \mathrm{MHz}\right.$, Methanol- $\left.d_{4}\right) \delta 175.90,153.52,139.31,138.60,137.63$, 130.34, 130.30, 129.38, 126.70, 126.42, 122.76, 122.02, 119.22, 112.65, 41.63. ESI: Calcd. for $\mathrm{C}_{17} \mathrm{H}_{15} \mathrm{~N}_{3} \mathrm{O}[\mathrm{M}+\mathrm{H}]^{+}$: 278.1293; found: 278.1334 .<smiles>O=C1CCN(c2nccc3ccccc23)c2ccccc2N1</smiles>

5-(isoquinolin-1-yl)-4,5-dihydro-1H-benzo[b][1,4]diazepin-2(3H)-one (57c) The product is obtained as white soild (isolated yield: $89 \%):{ }^{1} \mathrm{H}$ NMR (400 MHz, $\left.\mathrm{CDCl}_{3}\right) \delta 9.33(\mathrm{~s}, 1 \mathrm{H}), \delta 8.19$ $(\mathrm{d}, J=5.6 \mathrm{~Hz}, 1 \mathrm{H}), 7.57(\mathrm{~d}, J=8.1 \mathrm{~Hz}, 1 \mathrm{H}), 7.33(\mathrm{t}, J=7.3 \mathrm{~Hz}, 1 \mathrm{H}), 7.25(\mathrm{~d}, J=8.3 \mathrm{~Hz}, 2 \mathrm{H})$, $7.17-6.95(\mathrm{~m}, 3 \mathrm{H}), 6.87(\mathrm{t}, J=7.6 \mathrm{~Hz}, 1 \mathrm{H}), 6.56(\mathrm{~d}, J=7.9 \mathrm{~Hz}, 1 \mathrm{H}), 4.42(\mathrm{t}, J=6.8 \mathrm{~Hz}, 2 \mathrm{H})$, $2.79(\mathrm{t}, J=6.8 \mathrm{~Hz}, 2 \mathrm{H}) .{ }^{13} \mathrm{C} \mathrm{NMR}\left(101 \mathrm{MHz}, \mathrm{CDCl}_{3}\right) \delta 175.26,157.50,141.51,140.16,138.06$, 134.42, 129.25, 126.76, 126.67, 126.59, 126.09, 126.05, 125.68, 122.75, 121.59, 116.61, 53.64, 33.57. ESI: Calcd. for $\mathrm{C}_{18} \mathrm{H}_{15} \mathrm{~N}_{3} \mathrm{O}[\mathrm{M}+\mathrm{H}]^{+}:$290.1293; found: 290.1280 .<smiles>CCOC(=O)C(Cc1ccc(Nc2nccc3ccccc23)cc1)NC(=O)OC(C)(C)C</smiles>

(S)-ethyl 2-((tert-butoxycarbonyl)amino)-3-(4-(isoquinolin-1-ylamino)phenyl)propanoate (58c) The product is obtained as white soild (isolated yield: $77 \%):{ }^{1} \mathrm{H} N M R\left(400 \mathrm{MHz}, \mathrm{CDCl}_{3}\right) \delta$ $8.06(\mathrm{~d}, J=5.1 \mathrm{~Hz}, 1 \mathrm{H}), 7.96(\mathrm{~d}, J=8.0 \mathrm{~Hz}, 1 \mathrm{H}), 7.74(\mathrm{~d}, J=7.9 \mathrm{~Hz}, 1 \mathrm{H}), 7.66-7.57(\mathrm{~m}, 3 \mathrm{H})$, $7.53(\mathrm{t}, J=7.2 \mathrm{~Hz}, 1 \mathrm{H}), 7.11(\mathrm{~d}, J=6.5 \mathrm{~Hz}, 3 \mathrm{H}), 5.02(\mathrm{~d}, J=7.1 \mathrm{~Hz}, 1 \mathrm{H}), 4.61-4.47(\mathrm{~m}, 1 \mathrm{H})$, $4.18(\mathrm{~d}, J=6.8 \mathrm{~Hz}, 2 \mathrm{H}), 3.29-3.15(\mathrm{~m}, 2 \mathrm{H}), 1.43(\mathrm{~s}, 9 \mathrm{H}), 1.25(\mathrm{t}, J=6.9 \mathrm{~Hz}, 3 \mathrm{H}) .{ }^{13} \mathrm{C} \mathrm{NMR}$ $\left(101 \mathrm{MHz} \mathrm{CDCl}_{3}\right) \delta 171.98,155.25,152.21,140.35,139.31,137.47,130.25,130.07,129.92$, 
127.44, 126.57, 121.73, 120.44, 118.83, 113.38, 79.84, 61.33, 54.56, 37.58, 28.35, 14.20. ESI: Calcd. for $\mathrm{C}_{25} \mathrm{H}_{29} \mathrm{~N}_{3} \mathrm{O}_{4}[\mathrm{M}+\mathrm{H}]^{+}$: 436.2236 ; found: 436.2214 .<smiles></smiles>

isoquinolin-1-amine (59c) The product is obtained as white liquid (isolated yield: $15 \%):{ }^{1} \mathrm{H}$ NMR $\left(400 \mathrm{MHz}, \mathrm{CDCl}_{3}\right) \delta 7.90(\mathrm{~d}, J=6.0 \mathrm{~Hz}, 1 \mathrm{H}), 7.84(\mathrm{~d}, J=8.3 \mathrm{~Hz}, 1 \mathrm{H}), 7.71(\mathrm{~d}, J=8.1$ $\mathrm{Hz}, 1 \mathrm{H}), 7.64(\mathrm{t}, J=7.5 \mathrm{~Hz}, 1 \mathrm{H}), 7.51(\mathrm{t}, J=7.6 \mathrm{~Hz}, 1 \mathrm{H}), 7.05(\mathrm{~d}, J=5.9 \mathrm{~Hz}, 1 \mathrm{H}), 5.49$ (bs, 2 H). ${ }^{13} \mathrm{C} \mathrm{NMR}\left(101 \mathrm{MHz}, \mathrm{CDCl}_{3}\right) \delta 156.16,140.20,137.59,130.61,127.33,126.49,122.86$, 118.01, 112.71. ESI: Calcd. for $\mathrm{C}_{9} \mathrm{H}_{8} \mathrm{~N}_{2}[\mathrm{M}+\mathrm{H}]^{+}:$: 145.0766; found: 145.0754 .<smiles>CNc1nccc2ccccc12</smiles>

$\mathrm{N}$-methylisoquinolin-1-amine (60c) The product is obtained as white liquid (isolated yield: 80\%): ${ }^{1} \mathrm{H}$ NMR $\left(400 \mathrm{MHz}, \mathrm{CDCl}_{3}\right) \delta 8.32(\mathrm{~d}, J=7.7 \mathrm{~Hz}, 1 \mathrm{H}), 7.87(\mathrm{~d}, J=5.6 \mathrm{~Hz}, 1 \mathrm{H}), 7.76-$ 7.39 (m, $4 \mathrm{H}), 6.92(\mathrm{~d}, J=5.9 \mathrm{~Hz}, 1 \mathrm{H}), 3.27(\mathrm{~s}, 3 \mathrm{H}) .{ }^{13} \mathrm{C} \mathrm{NMR}\left(101 \mathrm{MHz}, \mathrm{CDCl}_{3}\right) \delta 154.47$, 136.62, 135.19, 131.55, 127.22, 127.17, 123.48, 118.47, 110.96, 29.55. ESI: Calcd. for $\mathrm{C}_{10} \mathrm{H}_{10} \mathrm{~N}_{2}$ $[\mathrm{M}+\mathrm{H}]^{+}:$159.0922; found: 159.0911 .<smiles>CCNC1NCCc2cccc3cccc1c23</smiles>

$\mathrm{N}$-ethylisoquinolin-1-amine (61c) The product is obtained as white liquid (isolated yield: 64\%): ${ }^{1} \mathrm{H}$ NMR $\left(400 \mathrm{MHz}, \mathrm{CDCl}_{3}\right) \delta 8.00(\mathrm{~d}, J=5.9 \mathrm{~Hz}, 1 \mathrm{H}), 7.76(\mathrm{~d}, J=8.3 \mathrm{~Hz}, 1 \mathrm{H}), 7.67(\mathrm{~d}, J=$ $8.1 \mathrm{~Hz}, 1 \mathrm{H}), 7.58(\mathrm{t}, J=7.5 \mathrm{~Hz}, 1 \mathrm{H}), 7.45(\mathrm{t}, J=7.6 \mathrm{~Hz}, 1 \mathrm{H}), 6.92(\mathrm{~d}, J=5.9 \mathrm{~Hz}, 1 \mathrm{H}), 5.24$ (bs, $1 \mathrm{H}), 3.70-3.60(\mathrm{~m}, 2 \mathrm{H}), 1.36(\mathrm{t}, J=7.2 \mathrm{~Hz}, 3 \mathrm{H}) .{ }^{13} \mathrm{C} \mathrm{NMR}\left(101 \mathrm{MHz}, \mathrm{CDCl}_{3}\right) \delta 156.43$, 142.48, 138.47, 131.02, 128.55, 127.18, 122.75, 119.54, 112.08, 38.04, 16.29. ESI: Calcd. for $\mathrm{C}_{11} \mathrm{H}_{12} \mathrm{~N}_{2}[\mathrm{M}+\mathrm{H}]^{+}:$: 173.1079; found: 173.0793.<smiles>CC(C)Nc1nccc2ccccc12</smiles>

$\mathrm{N}$-isopropylisoquinolin-1-amine (62c) The product is obtained as white liquid (isolated yield: 49\%): ${ }^{1} \mathrm{H}$ NMR $\left(400 \mathrm{MHz}, \mathrm{CDCl}_{3}\right) \delta 7.99(\mathrm{~d}, J=5.9 \mathrm{~Hz}, 1 \mathrm{H}), 7.76(\mathrm{~d}, J=8.4 \mathrm{~Hz}, 1 \mathrm{H}), 7.65(\mathrm{~d}$, $J=8.1 \mathrm{~Hz}, 1 \mathrm{H}), 7.57(\mathrm{t}, J=7.5 \mathrm{~Hz}, 1 \mathrm{H}), 7.45(\mathrm{t}, J=7.6 \mathrm{~Hz}, 1 \mathrm{H}), 6.89(\mathrm{~d}, J=5.9 \mathrm{~Hz}, 1 \mathrm{H})$, 5.19 (bs, $1 \mathrm{H}), 4.56-4.42(\mathrm{~m}, 1 \mathrm{H}), 1.34(\mathrm{~d}, J=6.4 \mathrm{~Hz}, 6 \mathrm{H}) .{ }^{13} \mathrm{C} \mathrm{NMR}\left(101 \mathrm{MHz}, \mathrm{CDCl}_{3}\right) \delta$ 154.23, 140.72, 137.11, 129.78, 127.20, 125.86, 121.46, 118.10, 110.48, 42.86, 23.07. ESI: Calcd. for $\mathrm{C}_{12} \mathrm{H}_{14} \mathrm{~N}_{2}[\mathrm{M}+\mathrm{H}]^{+}$: 187.1235; found: 187.1223 .<smiles>CC(C)(C)CNc1nccc2ccccc12</smiles>

$\mathrm{N}$-neopentylisoquinolin-1-amine (63c) The product is obtained as white liquid (isolated yield: 53\%): ${ }^{1} \mathrm{H}$ NMR $\left(400 \mathrm{MHz}, \mathrm{CDCl}_{3}\right) \delta 7.98(\mathrm{~d}, J=5.9 \mathrm{~Hz}, 1 \mathrm{H}), 7.76(\mathrm{~d}, J=8.3 \mathrm{~Hz}, 1 \mathrm{H}), 7.67(\mathrm{~d}$, $J=8.1 \mathrm{~Hz}, 1 \mathrm{H}), 7.58(\mathrm{t}, J=7.5 \mathrm{~Hz}, 1 \mathrm{H}), 7.47(\mathrm{t}, J=7.5 \mathrm{~Hz}, 1 \mathrm{H}), 6.90(\mathrm{~d}, J=5.8 \mathrm{~Hz}, 1 \mathrm{H})$, 5.29 (bs, $1 \mathrm{H}), 3.48(\mathrm{~d}, J=5.3 \mathrm{~Hz}, 2 \mathrm{H}), 1.07(\mathrm{~s}, 9 \mathrm{H}) .{ }^{13} \mathrm{C} \mathrm{NMR}\left(101 \mathrm{MHz}, \mathrm{CDCl}_{3}\right) \delta 155.26$, 
140.59, 137.13, 129.88, 127.31, 125.97, 121.25, 118.11, 110.60, 52.81, 31.86, 27.62. ESI: Calcd. for $\mathrm{C}_{14} \mathrm{H}_{18} \mathrm{~N}_{2}[\mathrm{M}+\mathrm{H}]^{+}: 215.1548$; found: 215.1536 .<smiles>c1ccc(CNc2nccc3ccccc23)cc1</smiles>

$N$-benzylisoquinolin-1-amine (64c) The product is obtained as white soild (isolated yield: $72 \%)$ : ${ }^{1} \mathrm{H} \mathrm{NMR}\left(400 \mathrm{MHz}, \mathrm{CDCl}_{3}\right) \delta 8.02(\mathrm{~d}, J=5.8 \mathrm{~Hz}, 1 \mathrm{H}), 7.77(\mathrm{~d}, J=8.3 \mathrm{~Hz}, 1 \mathrm{H}), 7.69(\mathrm{~d}, J=$ $8.1 \mathrm{~Hz}, 1 \mathrm{H}), 7.59$ (t, $J=7.5 \mathrm{~Hz}, 1 \mathrm{H}), 7.48-7.42(\mathrm{~m}, 3 \mathrm{H}), 7.39-7.28(\mathrm{~m}, 3 \mathrm{H}), 6.97(\mathrm{~d}, J=5.8$ $\mathrm{Hz}, 1 \mathrm{H}), 5.56(\mathrm{bs}, 1 \mathrm{H}), 4.83(\mathrm{~d}, J=4.5 \mathrm{~Hz}, 2 \mathrm{H}) .{ }^{13} \mathrm{C}$ NMR $\left(101 \mathrm{MHz}, \mathrm{CDCl}_{3}\right) \delta 154.76,140.94$, 139.30, 137.09, 129.86, 128.71, 128.10, 127.43, 127.23, 126.03, 121.50, 118.08, 111.29, 46.08. ESI: Calcd. for $\mathrm{C}_{16} \mathrm{H}_{14} \mathrm{~N}_{2}[\mathrm{M}+\mathrm{H}]^{+}:$235.1235; found: 235.1221 .<smiles>c1ccc2c(NC3CCC3)nccc2c1</smiles>

$\boldsymbol{N}$-cyclobutylisoquinolin-1-amine (65c) The product is obtained as white liquid (isolated yield: 51\%): ${ }^{1} \mathrm{H}$ NMR (400 MHz, $\left.\mathrm{CDCl}_{3}\right) \delta 8.01(\mathrm{~d}, J=5.8 \mathrm{~Hz}, 1 \mathrm{H}), 7.83(\mathrm{~d}, J=8.2 \mathrm{~Hz}, 1 \mathrm{H}), 7.70(\mathrm{~d}$, $J=8.1 \mathrm{~Hz}, 1 \mathrm{H}), 7.62(\mathrm{t}, J=7.5 \mathrm{~Hz}, 1 \mathrm{H}), 7.50(\mathrm{t}, J=7.6 \mathrm{~Hz}, 1 \mathrm{H}), 6.95(\mathrm{~d}, J=5.9 \mathrm{~Hz}, 1 \mathrm{H})$, 5.56 (bs, $1 \mathrm{H}), 4.78(\mathrm{~h}, J=7.5 \mathrm{~Hz}, 1 \mathrm{H}), 2.70-2.47(\mathrm{~m}, 2 \mathrm{H}), 2.01(\mathrm{p}, J=8.7 \mathrm{~Hz}, 2 \mathrm{H}), 1.92-1.76$ (m, $2 \mathrm{H}) .{ }^{13} \mathrm{C}$ NMR $\left(101 \mathrm{MHz}, \mathrm{CDCl}_{3}\right) \delta$ 154.24, 141.40, 137.11, 129.60, 127.16, 125.78, 121.37, 117.95, 110.84, 46.92, 31.88, 15.39. ESI: Calcd. for $\mathrm{C}_{13} \mathrm{H}_{14} \mathrm{~N}_{2}[\mathrm{M}+\mathrm{H}]^{+}$: 199.1235; found: 199.1230 .<smiles>c1ccc2c(NC3CCCC3)nccc2c1</smiles>

$\boldsymbol{N}$-cyclopentylisoquinolin-1-amine (66c) The product is obtained as white liquid (isolated yield: 60\%): ${ }^{1} \mathrm{H} \mathrm{NMR}\left(400 \mathrm{MHz}, \mathrm{CDCl}_{3}\right) \delta 8.00(\mathrm{~d}, J=5.9 \mathrm{~Hz}, 1 \mathrm{H}), 7.72(\mathrm{~d}, J=8.4 \mathrm{~Hz}, 1 \mathrm{H}), 7.66(\mathrm{~d}$, $J=8.1 \mathrm{~Hz}, 1 \mathrm{H}), 7.56(\mathrm{t}, J=7.4 \mathrm{~Hz}, 1 \mathrm{H}), 7.44(\mathrm{t}, J=7.4 \mathrm{~Hz}, 1 \mathrm{H}), 6.90(\mathrm{~d}, J=5.9 \mathrm{~Hz}, 1 \mathrm{H})$, 5.37-5.02 (m, $1 \mathrm{H}), 4.57(\mathrm{~h}, J=6.6 \mathrm{~Hz}, 1 \mathrm{H}), 2.20(\mathrm{dq}, J=12.0,6.2 \mathrm{~Hz}, 2 \mathrm{H}), 1.92-1.63(\mathrm{~m}, 4$ $\mathrm{H}), 1.55(\mathrm{dq}, J=12.6,6.4 \mathrm{~Hz}, 2 \mathrm{H}) .{ }^{13} \mathrm{C} \mathrm{NMR}\left(101 \mathrm{MHz}, \mathrm{CDCl}_{3}\right) \delta 154.87,141.51,137.06$, 129.51, 127.17, 125.69, 121.28, 118.13, 110.46, 53.03, 33.60, 23.89. EI: Calcd. for $\mathrm{C}_{14} \mathrm{H}_{16} \mathrm{~N}_{2}$ $[\mathrm{M}]^{+}:$212.1313; found: 212.1310.<smiles>c1ccc2c(NC3CCCCC3)nccc2c1</smiles>

$\mathrm{N}$-cyclohexylisoquinolin-1-amine (67c) The product is obtained as white liquid (isolated yield: 58\%): ${ }^{1} \mathrm{H}$ NMR $\left(400 \mathrm{MHz}, \mathrm{CDCl}_{3}\right) \delta 7.98(\mathrm{~d}, J=5.8 \mathrm{~Hz}, 1 \mathrm{H}), 7.75(\mathrm{~d}, J=8.4 \mathrm{~Hz}, 1 \mathrm{H}), 7.66(\mathrm{~d}$, $J=8.1 \mathrm{~Hz}, 1 \mathrm{H}), 7.58(\mathrm{t}, J=7.5 \mathrm{~Hz}, 1 \mathrm{H}), 7.46(\mathrm{t}, J=7.6 \mathrm{~Hz}, 1 \mathrm{H}), 6.89(\mathrm{~d}, J=5.8 \mathrm{~Hz}, 1 \mathrm{H})$, 5.19 (bs, $1 \mathrm{H}), 4.22(\mathrm{~s}, 1 \mathrm{H}), 2.18(\mathrm{~d}, J=10.1 \mathrm{~Hz}, 2 \mathrm{H}), 1.82-1.75(\mathrm{~m}, 2 \mathrm{H}), 1.73-1.64(\mathrm{~m}, 1 \mathrm{H})$, 1.52 (q, $J=12.1 \mathrm{~Hz}, 2 \mathrm{H}), 1.36-1.28(\mathrm{~m}, 3 \mathrm{H}) .{ }^{13} \mathrm{C}$ NMR $\left(101 \mathrm{MHz}, \mathrm{CDCl}_{3}\right) \delta 154.35,141.47$, 
137.18, 129.51, 127.17, 125.63, 121.27, 118.09, 110.31, 49.42, 33.55, 25.98, 25.09. EI: Calcd. for $\mathrm{C}_{15} \mathrm{H}_{18} \mathrm{~N}_{2}[\mathrm{M}]^{+}:$: 226.1470; found: 226.1466 .<smiles>OC1CCC(Nc2nccc3ccccc23)CC1</smiles>

4-(isoquinolin-1-ylamino)cyclohexanol (68c) The product is obtained as white liquid (isolated yield: $55 \%):{ }^{1} \mathrm{H}$ NMR $\left(400 \mathrm{MHz}, \mathrm{CDCl}_{3}\right) \delta 7.97(\mathrm{~d}, J=5.9 \mathrm{~Hz}, 1 \mathrm{H}), 7.67(\mathrm{dd}, J=17.4,8.2 \mathrm{~Hz}$, $2 \mathrm{H}), 7.56(\mathrm{t}, J=7.5 \mathrm{~Hz}, 1 \mathrm{H}), 7.43(\mathrm{t}, J=7.6 \mathrm{~Hz}, 1 \mathrm{H}), 6.90(\mathrm{~d}, J=5.9 \mathrm{~Hz}, 1 \mathrm{H}), 5.01(\mathrm{bs}, 1 \mathrm{H})$, 4.24-4.12 (m, $1 \mathrm{H}), 3.71$ (td, $J=10.6,5.2 \mathrm{~Hz}, 1 \mathrm{H}), 2.27(\mathrm{~d}, J=11.8 \mathrm{~Hz}, 2 \mathrm{H}), 2.04(\mathrm{~d}, J=12.2$ $\mathrm{Hz}, 2 \mathrm{H}), 1.74$ (bs, $1 \mathrm{H}), 1.60-1.47(\mathrm{~m}, 2 \mathrm{H}), 1.42-1.27$ (m, $2 \mathrm{H}) .{ }^{13} \mathrm{C} \mathrm{NMR}\left(101 \mathrm{MHz}, \mathrm{CDCl}_{3}\right) \delta$ $154.33,141.35,137.15,129.60,127.24,125.76,121.18,118.03,110.66,70.37,48.90,34.25$, 31.24. EI: Calcd. for $\mathrm{C}_{15} \mathrm{H}_{18} \mathrm{~N}_{2} \mathrm{O}$ [M] ${ }^{+}: 242.1419$; found: 242.1418 .<smiles>CC(=O)NC1CCC(Nc2nccc3ccccc23)CC1</smiles>

$\mathrm{N}$-(4-(isoquinolin-1-ylamino)cyclohexyl)acetamide (69c) The product is obtained as white soild (isolated yield: $25 \%):{ }^{1} \mathrm{H}$ NMR $\left(400 \mathrm{MHz}\right.$, Methanol- $\left.d_{4}\right) \delta 8.13(\mathrm{~d}, J=8.4 \mathrm{~Hz}, 1 \mathrm{H}), 7.73(\mathrm{~d}$, $J=6.0 \mathrm{~Hz}, 1 \mathrm{H}), 7.69-7.53(\mathrm{~m}, 2 \mathrm{H}), 7.46(\mathrm{t}, J=7.6 \mathrm{~Hz}, 1 \mathrm{H}), 6.87(\mathrm{~d}, J=6.0 \mathrm{~Hz}, 1 \mathrm{H}), 4.08$ $3.91(\mathrm{~m}, 1 \mathrm{H}), 3.79-3.61(\mathrm{~m}, 1 \mathrm{H}), 2.13(\mathrm{~d}, J=12.2 \mathrm{~Hz}, 2 \mathrm{H}), 1.97(\mathrm{~d}, J=12.0 \mathrm{~Hz}, 2 \mathrm{H}), 1.92(\mathrm{~s}$, $3 \mathrm{H}), 1.61-1.36$ (m, $4 \mathrm{H}) .{ }^{13} \mathrm{C}$ NMR (101 MHz, Methanol- $\left.d_{4}\right) \delta 171.10,154.95,139.17,137.24$, $129.88,126.41,125.70,122.46,118.60,109.82,49.05,31.15,31.01,21.28$. ESI: Calcd. for $\mathrm{C}_{17} \mathrm{H}_{21} \mathrm{~N}_{3} \mathrm{O}[\mathrm{M}+\mathrm{H}]^{+}: 284.1763$; found: 284.1758.<smiles>CNc1nccc2cc(Br)ccc12</smiles>

6-bromo- $\mathrm{N}$-methylisoquinolin-1-amine (70c) The product is obtained as white soild (isolated yield: $25 \%):{ }^{1} \mathrm{H}$ NMR $\left(400 \mathrm{MHz}, \mathrm{CDCl}_{3}\right) \delta 8.03(\mathrm{~d}, J=5.9 \mathrm{~Hz}, 1 \mathrm{H}), 7.83(\mathrm{~d}, J=1.4 \mathrm{~Hz}, 1 \mathrm{H})$, $7.62(\mathrm{~d}, J=8.8 \mathrm{~Hz}, 1 \mathrm{H}), 7.53(\mathrm{dd}, J=8.8,1.7 \mathrm{~Hz}, 1 \mathrm{H}), 6.83(\mathrm{~d}, J=5.9 \mathrm{~Hz}, 1 \mathrm{H}), 5.36(\mathrm{bs}, 1 \mathrm{H})$, $3.17(\mathrm{~d}, J=3.9 \mathrm{~Hz}, 3 \mathrm{H}) .{ }^{13} \mathrm{C} \mathrm{NMR}\left(101 \mathrm{MHz}, \mathrm{CDCl}_{3}\right) \delta 155.68,142.45,138.37,129.35,129.13$, 124.33, 123.24, 116.67, 109.74, 28.90. ESI: Calcd. for $\mathrm{C}_{10} \mathrm{H}_{9} \mathrm{BrN}_{2}[\mathrm{M}+\mathrm{H}]^{+}: 237.0027$; found: 237.0016 .<smiles>INc1ccc2ccccc2n1</smiles>

$\mathrm{N}$-methylquinolin-2-amine (71c) The product is obtained as white soild (isolated yield: 62\%): ${ }^{1} \mathrm{H}$ NMR $\left(400 \mathrm{MHz}, \mathrm{CDCl}_{3}\right) \delta 7.84(\mathrm{~d}, J=8.9 \mathrm{~Hz}, 1 \mathrm{H}), 7.74(\mathrm{~d}, J=8.4 \mathrm{~Hz}, 1 \mathrm{H}), 7.67-7.45(\mathrm{~m}$, $2 \mathrm{H}), 7.24(\mathrm{t}, J=7.4 \mathrm{~Hz}, 1 \mathrm{H}), 6.66(\mathrm{~d}, J=8.9 \mathrm{~Hz}, 1 \mathrm{H}), 4.96(\mathrm{bs}, 1 \mathrm{H}), 3.11(\mathrm{~d}, J=3.8 \mathrm{~Hz}, 3 \mathrm{H})$. ${ }^{13} \mathrm{C}$ NMR $\left(101 \mathrm{MHz}, \mathrm{CDCl}_{3}\right) \delta 157.59,147.85,137.38,129.63,127.48,125.92,123.30,122.04$, 111.15, 28.71. ESI: Calcd. for $\mathrm{C}_{10} \mathrm{H}_{10} \mathrm{~N}_{2}[\mathrm{M}+\mathrm{H}]^{+}:$: 159.0922; found: 159.0911 .<smiles>CNc1cc(C)c2ccccc2n1</smiles> 
N,4-dimethylquinolin-2-amine (72c) The product is obtained as white soild (isolated yield: 65\%): ${ }^{1} \mathrm{H}$ NMR $\left(400 \mathrm{MHz}, \mathrm{CDCl}_{3}\right) \delta 7.72(\mathrm{dd}, J=17.0,8.3 \mathrm{~Hz}, 2 \mathrm{H}), 7.52(\mathrm{t}, J=7.6 \mathrm{~Hz}, 1 \mathrm{H})$, $7.23(\mathrm{t}, J=7.5 \mathrm{~Hz}, 1 \mathrm{H}), 6.48$ (s, $1 \mathrm{H}), 5.06$ (bs, $1 \mathrm{H}), 3.06$ (s, $3 \mathrm{H}), 2.54(\mathrm{~s}, 3 \mathrm{H}) .{ }^{13} \mathrm{C}$ NMR $(101$ $\left.\mathrm{MHz}, \mathrm{CDCl}_{3}\right) \delta 157.30,147.33,145.42,129.49,126.02,123.66,123.57,121.93,111.06,28.66$, 18.89. ESI: Calcd. for $\mathrm{C}_{11} \mathrm{H}_{12} \mathrm{~N}_{2}[\mathrm{M}+\mathrm{H}]^{+}:$: 173.1079; found: 173.0779 .<smiles>CNc1ccc2cc(Br)ccc2n1</smiles>

6-bromo- $\mathrm{N}$-methylquinolin-2-amine (73c) The product is obtained as white soild (isolated yield: 28\%): ${ }^{1} \mathrm{H}$ NMR $\left(400 \mathrm{MHz}, \mathrm{CDCl}_{3}\right) \delta 7.72(\mathrm{~d}, J=7.6 \mathrm{~Hz}, 2 \mathrm{H}), 7.61-7.53(\mathrm{~m}, 2 \mathrm{H}), 6.64(\mathrm{~d}$, $J=9.0 \mathrm{~Hz}, 1 \mathrm{H}), 5.05(\mathrm{bs}, 1 \mathrm{H}), 3.08(\mathrm{~d}, J=4.5 \mathrm{~Hz}, 3 \mathrm{H}) .{ }^{13} \mathrm{C} \mathrm{NMR}\left(101 \mathrm{MHz}, \mathrm{CDCl}_{3}\right) \delta 157.77$, 146.71, 136.49, 132.88, 129.60, 127.85, 124.66, 114.98, 112.17, 28.76. ESI: Calcd. for $\mathrm{C}_{10} \mathrm{H}_{9} \mathrm{BrN}_{2}[\mathrm{M}+\mathrm{H}]^{+}: 237.0027$; found: 237.0014.<smiles>CC(C)(C)Nc1nccc2ccccc12</smiles>

$N$-(tert-butyl)isoquinolin-1-amine (74c) The product is obtained as white liquid (isolated yield: 48\%): ${ }^{1} \mathrm{H}$ NMR (400 MHz, $\left.\mathrm{CDCl}_{3}\right) \delta 8.56(\mathrm{~d}, J=5.9 \mathrm{~Hz}, 2 \mathrm{H}), 7.96(\mathrm{~d}, J=8.2 \mathrm{~Hz}, 1 \mathrm{H}), 7.81(\mathrm{t}$, $J=7.4 \mathrm{~Hz}, 1 \mathrm{H}), 7.74(\mathrm{dd}, J=16.8,6.6 \mathrm{~Hz}, 2 \mathrm{H}), 1.59(\mathrm{~s}, 9 \mathrm{H}) .{ }^{13} \mathrm{C} \mathrm{NMR}\left(101 \mathrm{MHz}, \mathrm{CDCl}_{3}\right) \delta$ 159.81, 141.90, 138.00, 130.62, 127.62, 126.57, 125.03, 124.28, 121.82, 70.30, 27.11. ESI: Calcd. for $\mathrm{C}_{13} \mathrm{H}_{16} \mathrm{~N}_{2}[\mathrm{M}+\mathrm{H}]^{+}$: 201.1392; found: 201.1390.<smiles>COc1ccc(Nc2ccc3ccccc3n2)cc1</smiles>

$\mathrm{N}$-(4-methoxyphenyl)quinolin-2-amine (75c) The product is obtained as white soild (isolated yield: $72 \%):{ }^{1} \mathrm{H}$ NMR $\left(400 \mathrm{MHz}, \mathrm{CDCl}_{3}\right) \delta 7.86(\mathrm{~d}, J=9.0 \mathrm{~Hz}, 1 \mathrm{H}), 7.73(\mathrm{~d}, J=8.4 \mathrm{~Hz}, 1 \mathrm{H})$, 7.65-7.49 (m, $2 \mathrm{H}), 7.39$ (d, $J=8.8 \mathrm{~Hz}, 2 \mathrm{H}), 7.33-7.24(\mathrm{~m}, 1 \mathrm{H}), 6.91(\mathrm{~d}, J=8.8 \mathrm{~Hz}, 2 \mathrm{H}), 6.86$ $(\mathrm{d}, J=9.0 \mathrm{~Hz}, 1 \mathrm{H}), 3.81(\mathrm{~s}, 3 \mathrm{H}) .{ }^{13} \mathrm{C}$ NMR $\left(101 \mathrm{MHz}, \mathrm{CDCl}_{3}\right) \delta 156.59,155.33,147.02,138.11$, 132.64, 130.01, 127.50, 125.85, 124.16, 123.80, 122.94, 114.63, 110.91, 55.58. ESI: Calcd. for $\mathrm{C}_{16} \mathrm{H}_{13} \mathrm{~N}_{2} \mathrm{O}[\mathrm{M}+\mathrm{H}]^{+}:$: 251.1184; found: 251.1172.<smiles>COc1ccc(Nc2ccncc2)cc1</smiles>

$\mathrm{N}$-(4-methoxyphenyl)pyridin-4-amine (76c) The product is obtained as white soild (isolated yield: 77\%): ${ }^{1} \mathrm{H}$ NMR $\left(400 \mathrm{MHz}, \mathrm{CDCl}_{3}\right) \delta 8.08(\mathrm{~d}, J=6.6 \mathrm{~Hz}, 2 \mathrm{H}), 7.24(\mathrm{~d}, J=9.0 \mathrm{~Hz}, 2 \mathrm{H})$, $6.97(\mathrm{~d}, J=8.8 \mathrm{~Hz}, 2 \mathrm{H}), 6.85(\mathrm{~d}, J=6.5 \mathrm{~Hz}, 2 \mathrm{H}), 4.44$ (bs, $1 \mathrm{H}), 3.83(\mathrm{~s}, 3 \mathrm{H}) .{ }^{13} \mathrm{C}$ NMR $(101$ $\left.\mathrm{MHz}, \mathrm{CDCl}_{3}\right) \delta 159.13,157.09,145.98,137.48,127.21,115.63,107.98,55.62$. ESI: Calcd. for $\mathrm{C}_{12} \mathrm{H}_{12} \mathrm{~N}_{2} \mathrm{O}[\mathrm{M}+\mathrm{H}]^{+}:$201.1028; found: 201.1014. 
<smiles>COc1ccc(Nc2nccn2-c2ccccc2)cc1</smiles>

$\mathrm{N}$-(4-methoxyphenyl)pyrimidin-2-amine (77c) The product is obtained as white soild (isolated yield: 50\%): ${ }^{1} \mathrm{H}$ NMR $\left(400 \mathrm{MHz}, \mathrm{CDCl}_{3}\right) \delta 8.37(\mathrm{~d}, J=4.7 \mathrm{~Hz}, 2 \mathrm{H}), 7.55-7.43(\mathrm{~m}, 3 \mathrm{H}), 6.90(\mathrm{~d}$, $J=8.7 \mathrm{~Hz}, 2 \mathrm{H}), 6.66$ (t, $J=4.7 \mathrm{~Hz}, 1 \mathrm{H}), 3.80(\mathrm{~s}, 3 \mathrm{H}) .{ }^{13} \mathrm{C} \mathrm{NMR}\left(101 \mathrm{MHz}, \mathrm{CDCl}_{3}\right) \delta 160.47$, $157.99,155.88,132.22,122.34,114.27,111.93,55.55$. ESI: Calcd. for $\mathrm{C}_{11} \mathrm{H}_{11} \mathrm{~N}_{3} \mathrm{O}[\mathrm{M}+\mathrm{H}]^{+}$: 202.0980; found: 202.0973 .<smiles>COc1ccc(Nc2cccn2-c2ccccc2)cc1</smiles>

$\boldsymbol{N}$-(4-methoxyphenyl)pyridazin-3-amine (78c) The product is obtained as white soild (isolated yield: $35 \%):{ }^{1} \mathrm{H}$ NMR $\left(400 \mathrm{MHz}, \mathrm{CDCl}_{3}\right) \delta 8.61(\mathrm{~d}, J=4.4 \mathrm{~Hz}, 1 \mathrm{H}), 7.38$ (bs, $\left.1 \mathrm{H}\right), 7.26$ (d, $J$ $=8.9 \mathrm{~Hz}, 2 \mathrm{H}), 7.18(\mathrm{dd}, J=9.1,4.5 \mathrm{~Hz}, 1 \mathrm{H}), 6.92(\mathrm{dd}, J=9.3,2.9 \mathrm{~Hz}, 3 \mathrm{H}), 3.82(\mathrm{~s}, 3 \mathrm{H}) .{ }^{13} \mathrm{C}$ NMR $\left(101 \mathrm{MHz}, \mathrm{CDCl}_{3}\right) \delta 158.70,156.58,143.68,131.15,127.02,124.29,114.33,111.83$, 54.93. ESI: Calcd. for $\mathrm{C}_{11} \mathrm{H}_{11} \mathrm{~N}_{3} \mathrm{O}$ [M+H] $]^{+}$: 202.0980; found: 202.0968 .<smiles>COc1ccc(Nc2nccs2)cc1</smiles>

$\mathrm{N}$-(4-methoxyphenyl)thiazol-2-amine (79c) The product is obtained as white soild (isolated yield: $33 \%):{ }^{1} \mathrm{H}$ NMR $\left(400 \mathrm{MHz}, \mathrm{CDCl}_{3}\right) \delta 7.29(\mathrm{~d}, J=8.8 \mathrm{~Hz}, 2 \mathrm{H}), 7.23(\mathrm{~s}, 1 \mathrm{H}), 6.91(\mathrm{~d}, J=$ $8.7 \mathrm{~Hz}, 2 \mathrm{H}), 6.55(\mathrm{~s}, 1 \mathrm{H}), 3.81$ (s, $3 \mathrm{H}) .{ }^{13} \mathrm{C}$ NMR $\left(101 \mathrm{MHz}, \mathrm{CDCl}_{3}\right) \delta 168.05,156.55,137.95$, 133.60, 121.98, 114.83, 106.84, 55.57. ESI: Calcd. for $\mathrm{C}_{10} \mathrm{H}_{10} \mathrm{~N}_{2} \mathrm{OS}[\mathrm{M}+\mathrm{H}]^{+}: 207.0592$; found: 207.0582 .<smiles>COc1ccc(Nc2nccc3[nH]ccc23)cc1</smiles>

$\mathbf{N}$-(4-methoxyphenyl)-1H-pyrrolo[3,2-c]pyridin-4-amine (80c) The product is obtained as white soild (isolated yield: $56 \%$ ): ${ }^{1} \mathrm{H} \mathrm{NMR}\left(400 \mathrm{MHz}, \mathrm{CDCl}_{3}\right) \delta 9.97(\mathrm{bs}, 1 \mathrm{H}), 7.60(\mathrm{~s}, 1 \mathrm{H})$, $7.34(\mathrm{~d}, J=7.5 \mathrm{~Hz}, 2 \mathrm{H}), 6.96(\mathrm{~s}, 1 \mathrm{H}), 6.85(\mathrm{~d}, J=8.0 \mathrm{~Hz}, 2 \mathrm{H}), 6.81(\mathrm{~d}, J=6.0 \mathrm{~Hz}, 1 \mathrm{H}), 6.04$ (s, $1 \mathrm{H}), 3.78(\mathrm{~s}, 3 \mathrm{H}) .{ }^{13} \mathrm{C}$ NMR $\left(101 \mathrm{MHz}, \mathrm{CDCl}_{3}\right) \delta 156.74,150.27,140.74,135.57,132.66$, 125.03, 123.18, 114.35, 110.72, 101.48, 100.34, 55.56. ESI: Calcd. for $\mathrm{C}_{14} \mathrm{H}_{13} \mathrm{~N}_{3} \mathrm{O}[\mathrm{M}+\mathrm{H}]^{+}$: 240.1137; found: 240.1121 .<smiles></smiles> 
3-ethyl-3-(4-(isoquinolin-1-ylamino)phenyl)piperidine-2,6-dione (81c) The product is obtained as white soild (isolated yield: $53 \%):{ }^{1} \mathrm{H}$ NMR $\left(400 \mathrm{MHz}, \mathrm{CDCl}_{3}\right) \delta 8.27-8.02(\mathrm{~m}, 2 \mathrm{H})$, $7.95(\mathrm{~d}, J=8.4 \mathrm{~Hz}, 1 \mathrm{H}), 7.79-7.61(\mathrm{~m}, 4 \mathrm{H}), 7.54$ (t, $J=7.6 \mathrm{~Hz}, 1 \mathrm{H}), 7.41-7.20$ (m, $3 \mathrm{H}), 7.15$ $(\mathrm{d}, J=5.7 \mathrm{~Hz}, 1 \mathrm{H}), 2.69-2.31(\mathrm{~m}, 3 \mathrm{H}), 2.29-2.16(\mathrm{~m}, 1 \mathrm{H}), 2.06(\mathrm{dq}, J=14.6,7.3 \mathrm{~Hz}, 1 \mathrm{H})$, $1.92(\mathrm{dq}, J=14.5,7.3 \mathrm{~Hz}, 1 \mathrm{H}), 0.89(\mathrm{t}, J=7.3 \mathrm{~Hz}, 3 \mathrm{H}) .{ }^{13} \mathrm{C}$ NMR $\left(101 \mathrm{MHz}, \mathrm{CDCl}_{3}\right) \delta 175.37$, 172.44, 151.91, 140.76, 139.97, 137.50, 132.27, 130.03, 127.52, 126.82, 126.64, 121.47, 120.13, 118.90, 113.84, 50.68, 32.96, 29.38, 27.07, 9.09. ESI: Calcd. for $\mathrm{C}_{22} \mathrm{H}_{21} \mathrm{~N}_{3} \mathrm{O}_{2}[\mathrm{M}+\mathrm{H}]^{+}: 360.1712$; found: 360.1689 .

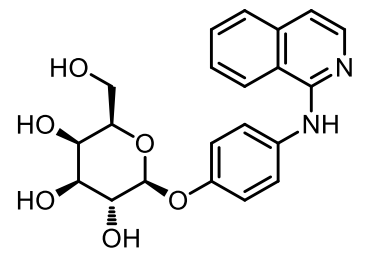

(2R,3R,4S,5R,6S)-2-(hydroxymethyl)-6-(4-(isoquinolin-1-ylamino)phenoxy)tetrahydro-2Hpyran-3,4,5-triol (82c) The product is obtained as white soild (isolated yield: $35 \%)$ : ${ }^{1} \mathrm{H}$ NMR $\left(400 \mathrm{MHz}\right.$, Methanol- $\left.d_{4}\right) \delta 8.35(\mathrm{~d}, J=8.4 \mathrm{~Hz}, 1 \mathrm{H}), 7.81-7.68(\mathrm{~m}, 3 \mathrm{H}), 7.60(\mathrm{t}, J=7.6 \mathrm{~Hz}, 1$ H), $7.49(\mathrm{~d}, J=8.8 \mathrm{~Hz}, 2 \mathrm{H}), 7.17(\mathrm{~d}, J=8.9 \mathrm{~Hz}, 2 \mathrm{H}), 7.10(\mathrm{~d}, J=6.1 \mathrm{~Hz}, 1 \mathrm{H}), 4.88(\mathrm{~s}, 1 \mathrm{H})$, $3.92(\mathrm{~d}, J=3.2 \mathrm{~Hz}, 1 \mathrm{H}), 3.85-3.74(\mathrm{~m}, 3 \mathrm{H}), 3.69$ (t, $J=6.0 \mathrm{~Hz}, 1 \mathrm{H}), 3.60(\mathrm{dd}, J=9.7,3.3 \mathrm{~Hz}$, $1 \mathrm{H}) .{ }^{13} \mathrm{C}$ NMR $\left(101 \mathrm{MHz}\right.$, Methanol- $\left.d_{4}\right) \delta 154.59,153.71,137.61,134.24,130.68,126.77$, 126.58, 123.93, 122.86, 118.95, 117.27, 112.20, 102.14, 75.55, 73.50, 70.96, 68.85, 61.03. ESI: Calcd. for $\mathrm{C}_{21} \mathrm{H}_{22} \mathrm{~N}_{2} \mathrm{O}_{6}[\mathrm{M}+\mathrm{H}]^{+}: 399.1556$; found: 399.1540 .

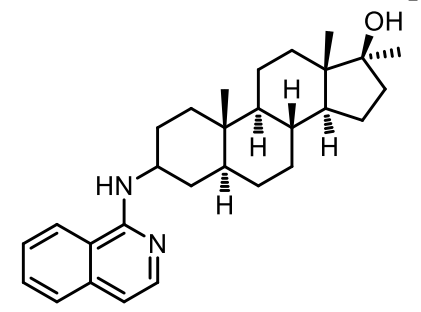

(5S,8R,9S,10S,13S,14S,17S)-3-(isoquinolin-1-ylamino)-10,13,17-trimethylhexadecahydro-1 H-cyclopenta[a]phenanthren-17-ol (83c) The product is obtained as white soild (isolated yield: 56\%): ${ }^{1} \mathrm{H}$ NMR $\left(400 \mathrm{MHz}, \mathrm{CDCl}_{3}\right) \delta 7.96(\mathrm{~d}, J=5.9 \mathrm{~Hz}, 1 \mathrm{H}), 7.85(\mathrm{~s}, 1 \mathrm{H}), 7.71-7.54(\mathrm{~m}, 2 \mathrm{H})$, $7.47(\mathrm{t}, J=7.4 \mathrm{~Hz}, 1 \mathrm{H}), 6.89$ (d, $J=5.9 \mathrm{~Hz}, 1 \mathrm{H}), 5.35$ (bs, $1 \mathrm{H}), 4.25$ (s, $1 \mathrm{H}), 2.07$ (d, $J=11.5$ $\mathrm{Hz}, 1 \mathrm{H}), 1.90-1.10(\mathrm{~m}, 23 \mathrm{H}), 0.93-0.80(\mathrm{~m}, 7 \mathrm{H}), 0.67$ (t, $J=8.6 \mathrm{~Hz}, 1 \mathrm{H}) .{ }^{13} \mathrm{C}$ NMR $(101$ $\left.\mathrm{MHz}, \mathrm{CDCl}_{3}\right) \delta 154.48,141.40,137.28,129.57,127.21,125.68,121.31,118.16,110.40,81.74$, 54.62, 50.81, 50.31, 45.68, 45.62, 39.14, 37.76, 36.59, 35.94, 35.90, 31.85, 31.79, 29.41, 28.73, 25.92, 23.33, 20.88, 14.02, 12.45. EI: Calcd. for $\mathrm{C}_{29} \mathrm{H}_{40} \mathrm{~N}_{2} \mathrm{O}[\mathrm{M}]^{+}: 432.3141$; found: 432.3142 .

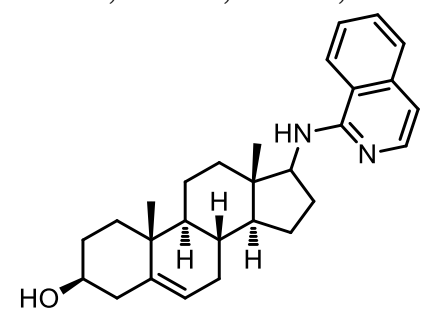

(3S,8R,9S,10R,13S,14S)-17-(isoquinolin-1-ylamino)-10,13-dimethyl-2,3,4,7,8,9,10,11,12,13,1 4,15,16,17-tetradecahydro-1H-cyclopenta[a]phenanthren-3-ol (84c) The product is obtained as white soild (isolated yield: $45 \%):{ }^{1} \mathrm{H}$ NMR (400 MHz, $\left.\mathrm{CDCl}_{3}\right) \delta 7.97(\mathrm{~d}, J=5.8 \mathrm{~Hz}, 1 \mathrm{H}$ ), $7.78(\mathrm{~d}, J=8.3 \mathrm{~Hz}, 1 \mathrm{H}), 7.70(\mathrm{~d}, J=8.0 \mathrm{~Hz}, 1 \mathrm{H}), 7.62(\mathrm{t}, J=7.4 \mathrm{~Hz}, 1 \mathrm{H}), 7.50(\mathrm{t}, J=7.6 \mathrm{~Hz}, 1$ 
H), $6.92(\mathrm{~d}, J=5.8 \mathrm{~Hz}, 1 \mathrm{H}), 5.54-5.19(\mathrm{~m}, 2 \mathrm{H}), 4.45(\mathrm{q}, J=8.4 \mathrm{~Hz}, 1 \mathrm{H}), 3.57(\mathrm{dt}, J=11.1,6.2$ $\mathrm{Hz}, 1 \mathrm{H}), 2.53-2.21(\mathrm{~m}, 3 \mathrm{H}), 2.12-2.00(\mathrm{~m} 1 \mathrm{H}), 1.83(\mathrm{dd}, J=32.6,8.5 \mathrm{~Hz}, 4 \mathrm{H}), 1.70-1.23(\mathrm{~m}$, $10 \mathrm{H}), 1.19-0.97(\mathrm{~m}, 5 \mathrm{H}), 0.93(\mathrm{~s}, 3 \mathrm{H}) .{ }^{13} \mathrm{C} \mathrm{NMR}\left(101 \mathrm{MHz}, \mathrm{CDCl}_{3}\right) \delta 155.13,141.01,137.28$, $129.84,127.36,125.91,121.44,121.43,121.27,118.17,110.54,71.77,60.57,53.06,50.42$, 43.07 , 42.41, 37.37, 37.25, 36.69, 32.30, 31.77, 31.68, 29.50, 23.90, 20.85, 19.49, 12.27. ESI: Calcd. for $\mathrm{C}_{28} \mathrm{H}_{36} \mathrm{~N}_{2} \mathrm{O}[\mathrm{M}+\mathrm{H}]^{+}:$: 417.2906; found: 417.2904 .

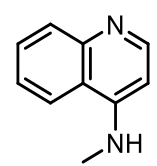

$\mathrm{N}$-methylquinolin-4-amine (85c) The product is obtained as white soild (isolated yield: $87 \%$ ): ${ }^{1} \mathrm{H}$ NMR $\left(400 \mathrm{MHz}, \mathrm{CD}_{3} \mathrm{OD}\right) \delta 8.42(\mathrm{~d}, J=7.1 \mathrm{~Hz}, 1 \mathrm{H}), 8.34(\mathrm{~d}, J=8.5 \mathrm{~Hz}, 1 \mathrm{H}), 7.97(\mathrm{t}, J=$ $7.6 \mathrm{~Hz}, 1 \mathrm{H}), 7.87$ (d, $J=8.4 \mathrm{~Hz}, 1 \mathrm{H}), 7.73$ (t, $J=7.7 \mathrm{~Hz}, 1 \mathrm{H}), 6.83(\mathrm{~d}, J=7.1 \mathrm{~Hz}, 1 \mathrm{H}), 3.23$ (s, $3 \mathrm{H}) .{ }^{13} \mathrm{C}$ NMR $\left(101 \mathrm{MHz}, \mathrm{CD}_{3} \mathrm{OD}\right) \delta 158.49,143.22,139.20,134.84,128.22,123.68,121.13$, 118.34, 98.97, 30.56. ESI: Calcd. for $\mathrm{C}_{10} \mathrm{H}_{10} \mathrm{~N}_{2}[\mathrm{M}+\mathrm{H}]^{+}:$: 159.0917; found: 159.0919. 
7. ${ }^{1} \mathrm{H}$ and ${ }^{13} \mathrm{C}$ spectra of products

$N$-methyl- $N$-phenylpyridin-4-amine (1c)
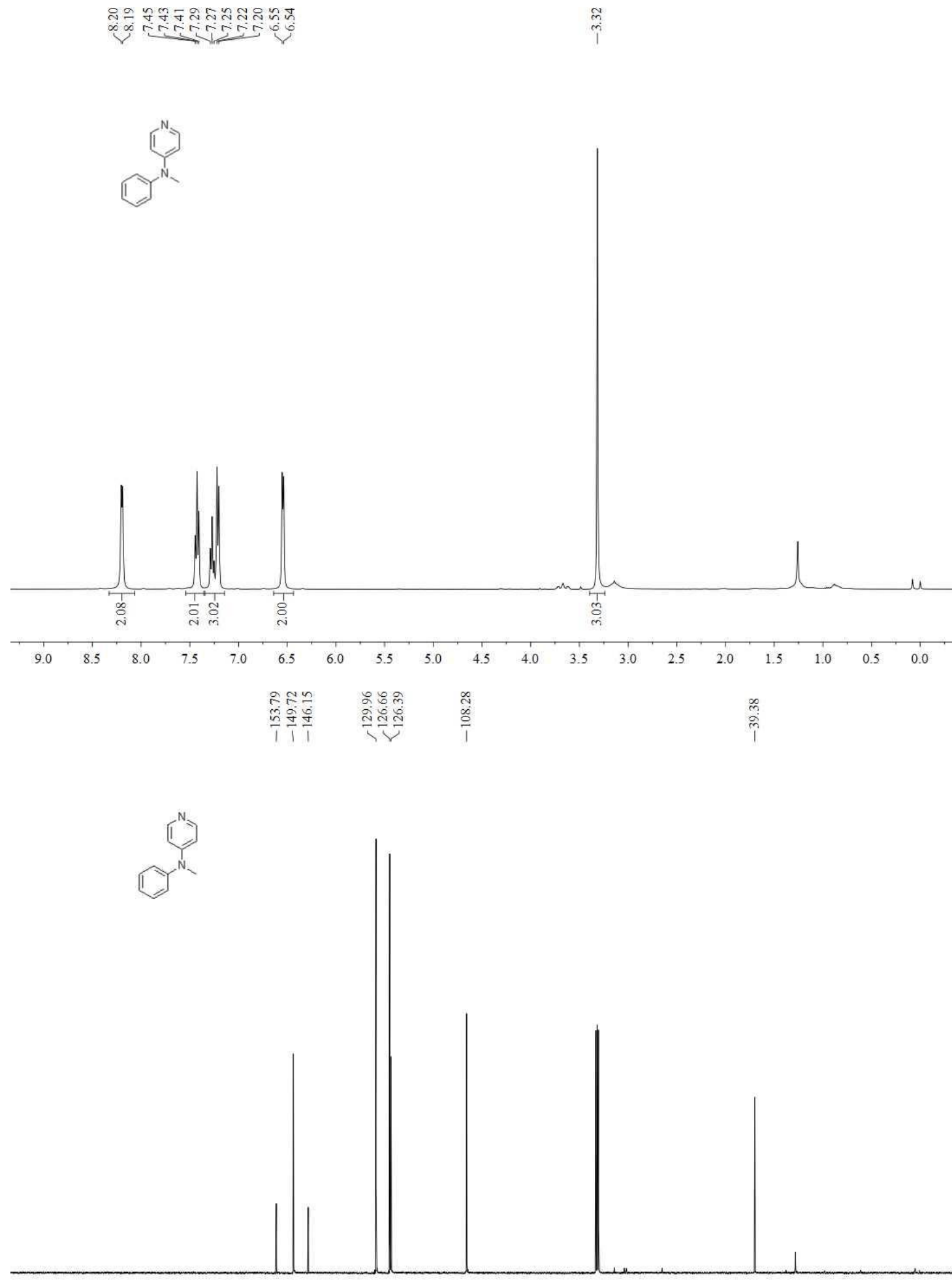

$\begin{array}{llllllllllllllllllllllllll}210 & 200 & 190 & 180 & 170 & 160 & 150 & 140 & 130 & 120 & 110 & 100 & 90 & 80 & 70 & 60 & 50 & 40 & 30 & 20 & 10 & 0\end{array}$ 
$N, 2$-dimethyl- $N$-phenylpyridin-4-amine (2c)
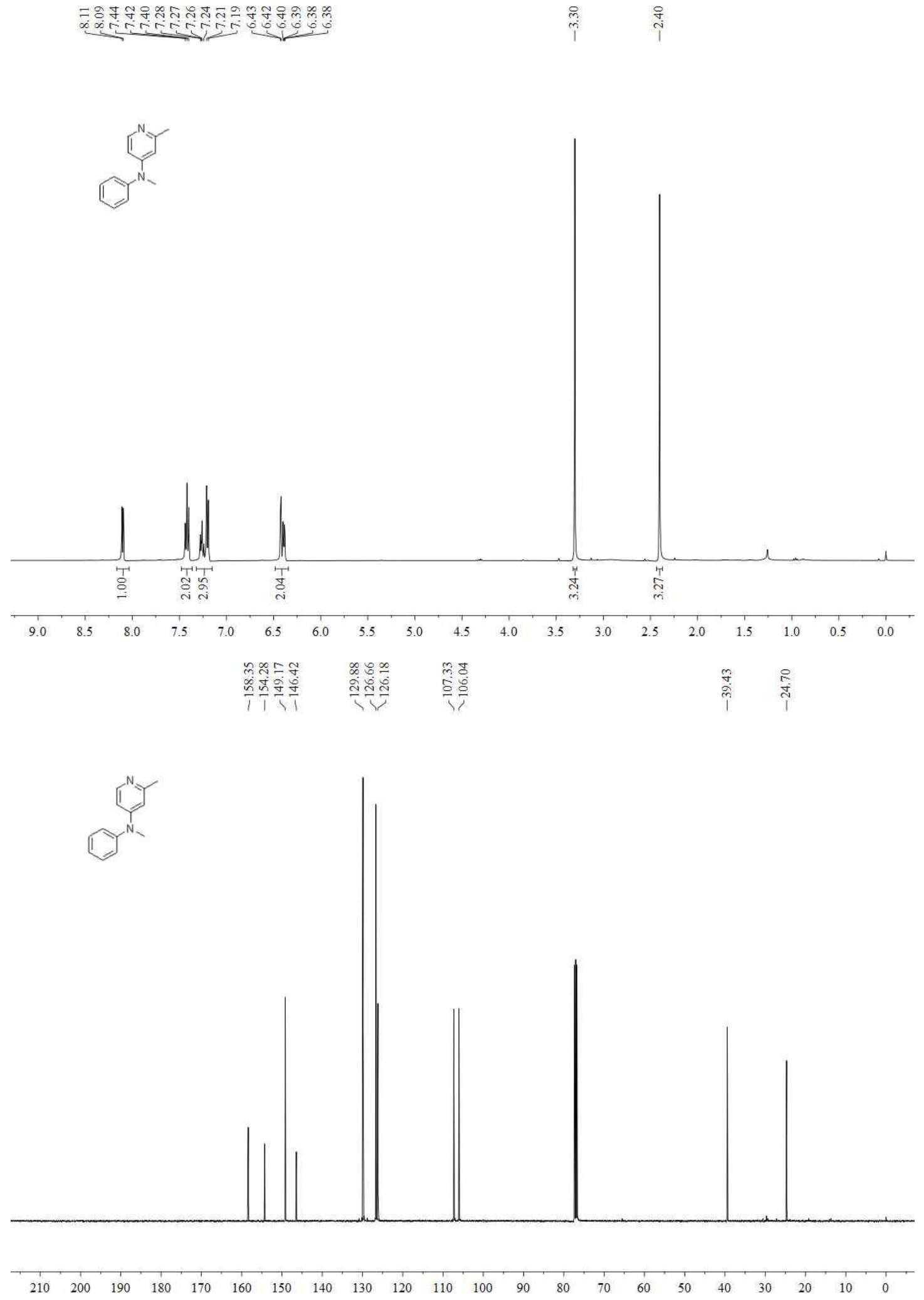


\section{(4-(methyl(phenyl)amino)pyridin-2-yl)methanol (3c)}
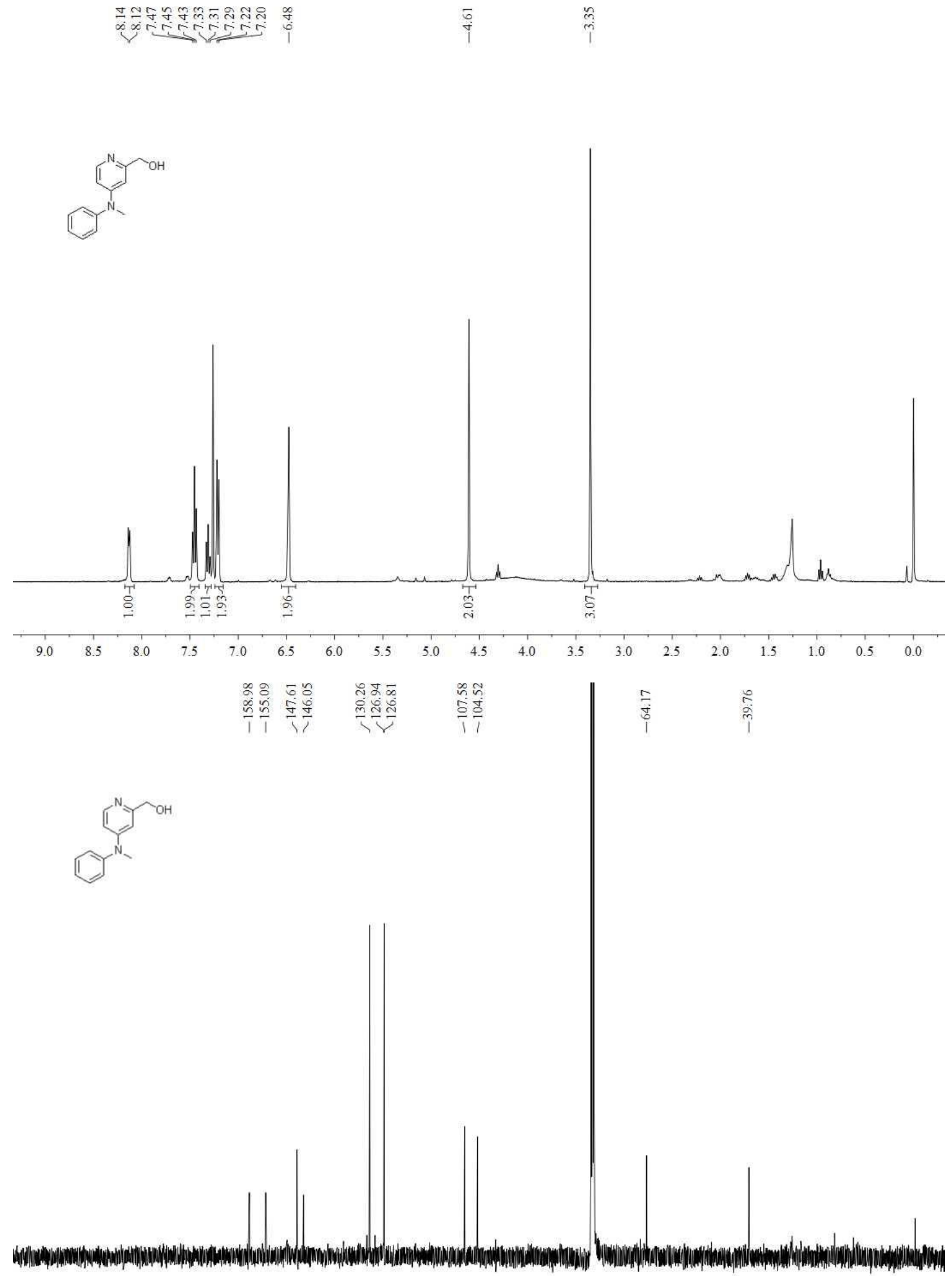

$\begin{array}{llllllllllllllllllllll}210 & 200 & 190 & 180 & 170 & 160 & 150 & 140 & 130 & 120 & 110 & 100 & 90 & 80 & 70 & 60 & 50 & 40 & 30 & 20 & 10 & 0\end{array}$ 
2-(tert-butyl)- $N$-methyl- $N$-phenylpyridin-4-amine (4c)

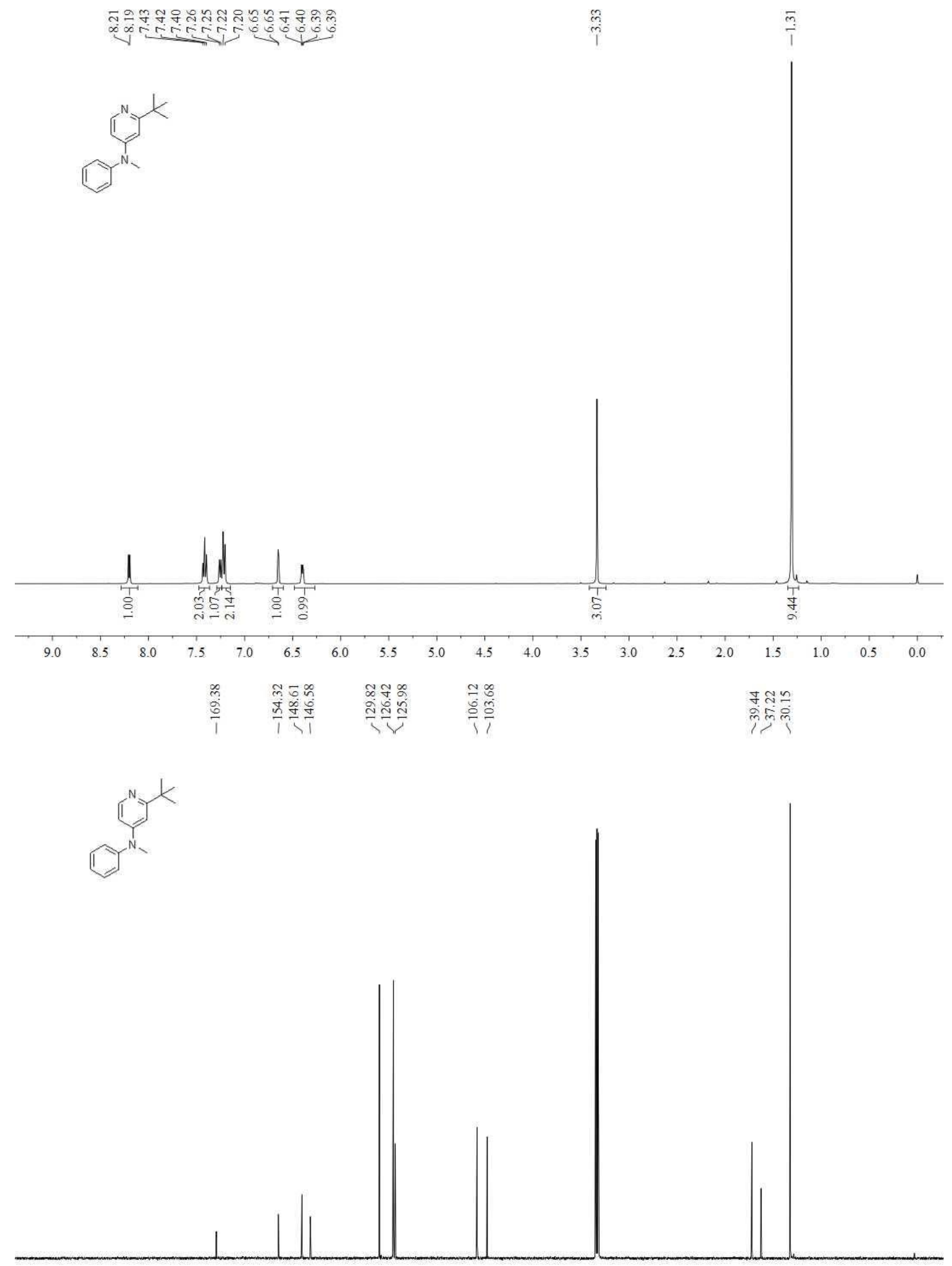

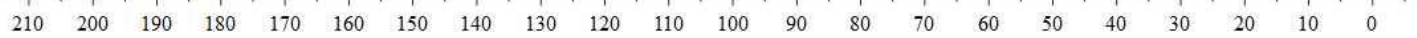


$N, 2,6$-trimethyl- $N$-phenylpyridin-4-amine (5c)

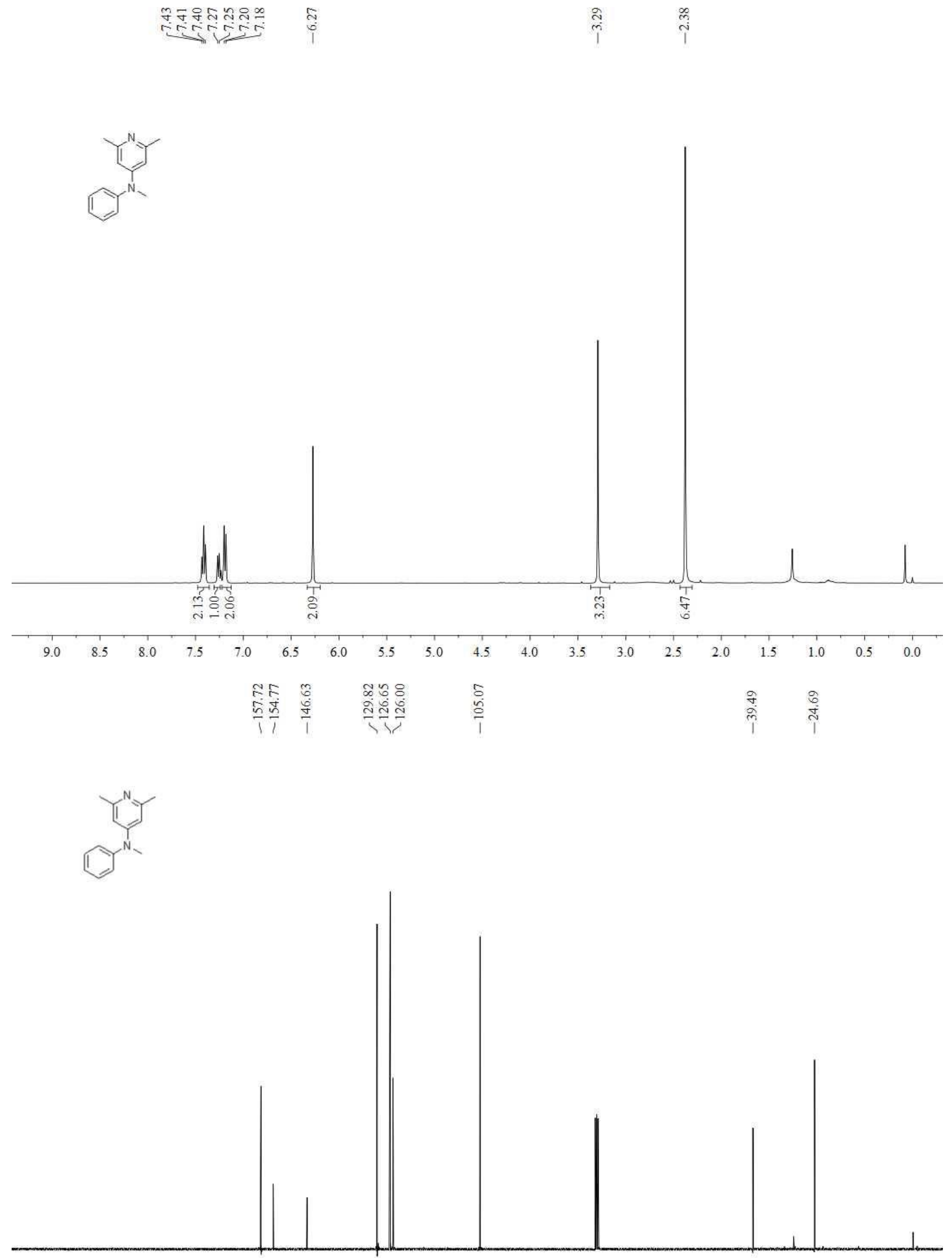

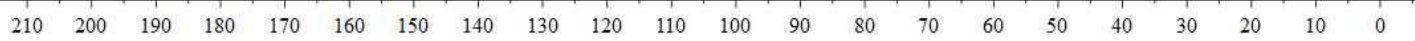




\section{2-chloro- $N$-methyl- $N$-phenylpyridin-4-amine (6c)}
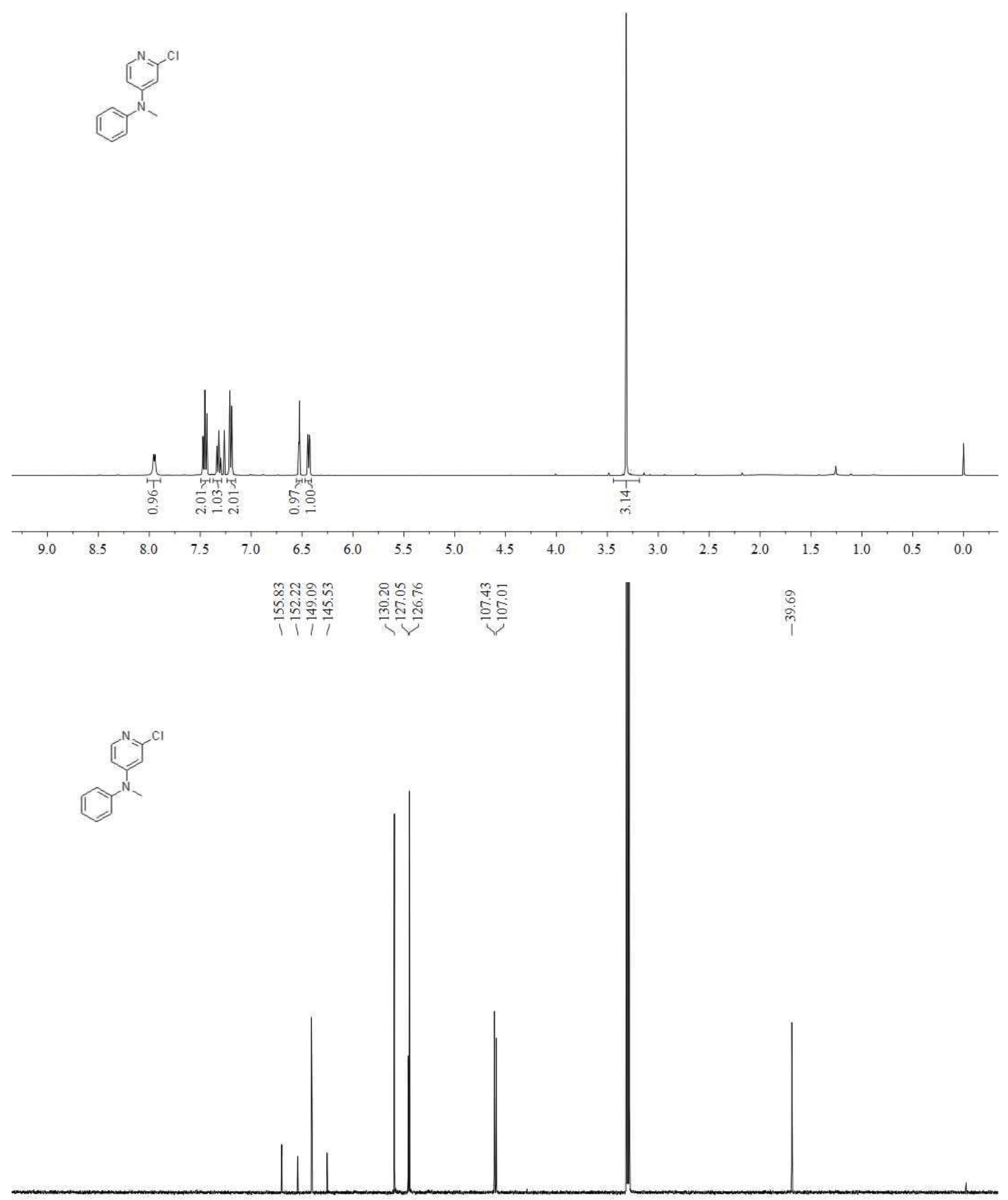


\section{1-(4-(methyl(phenyl)amino)pyridin-2-yl)ethanone (7c)}

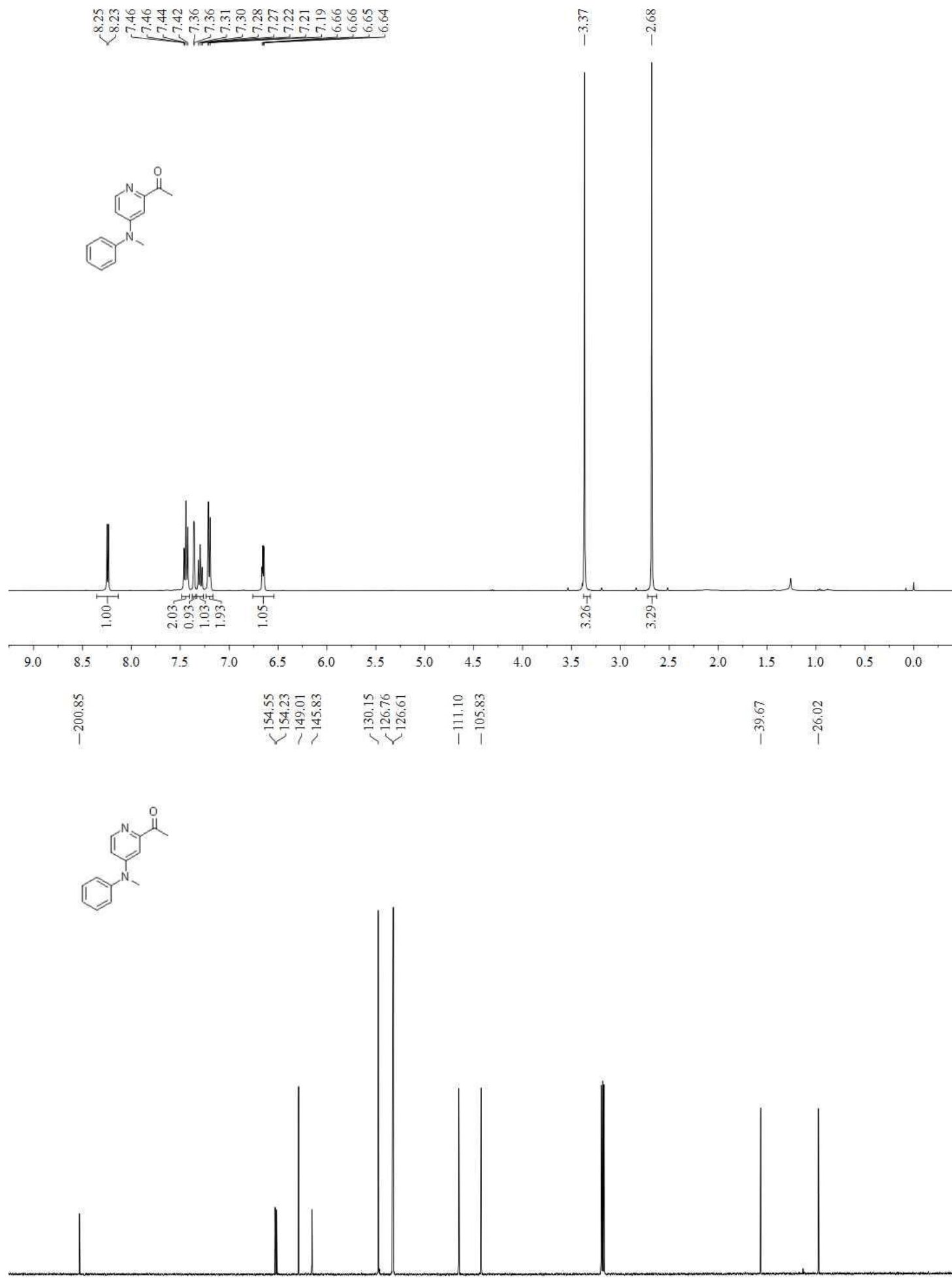

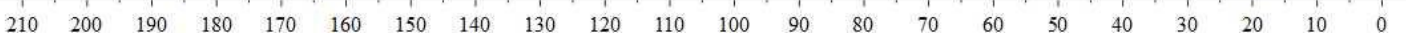


$N$-methyl- $N$-phenylpyrimidin-2-amine (8c)

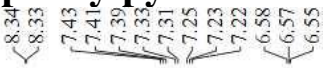

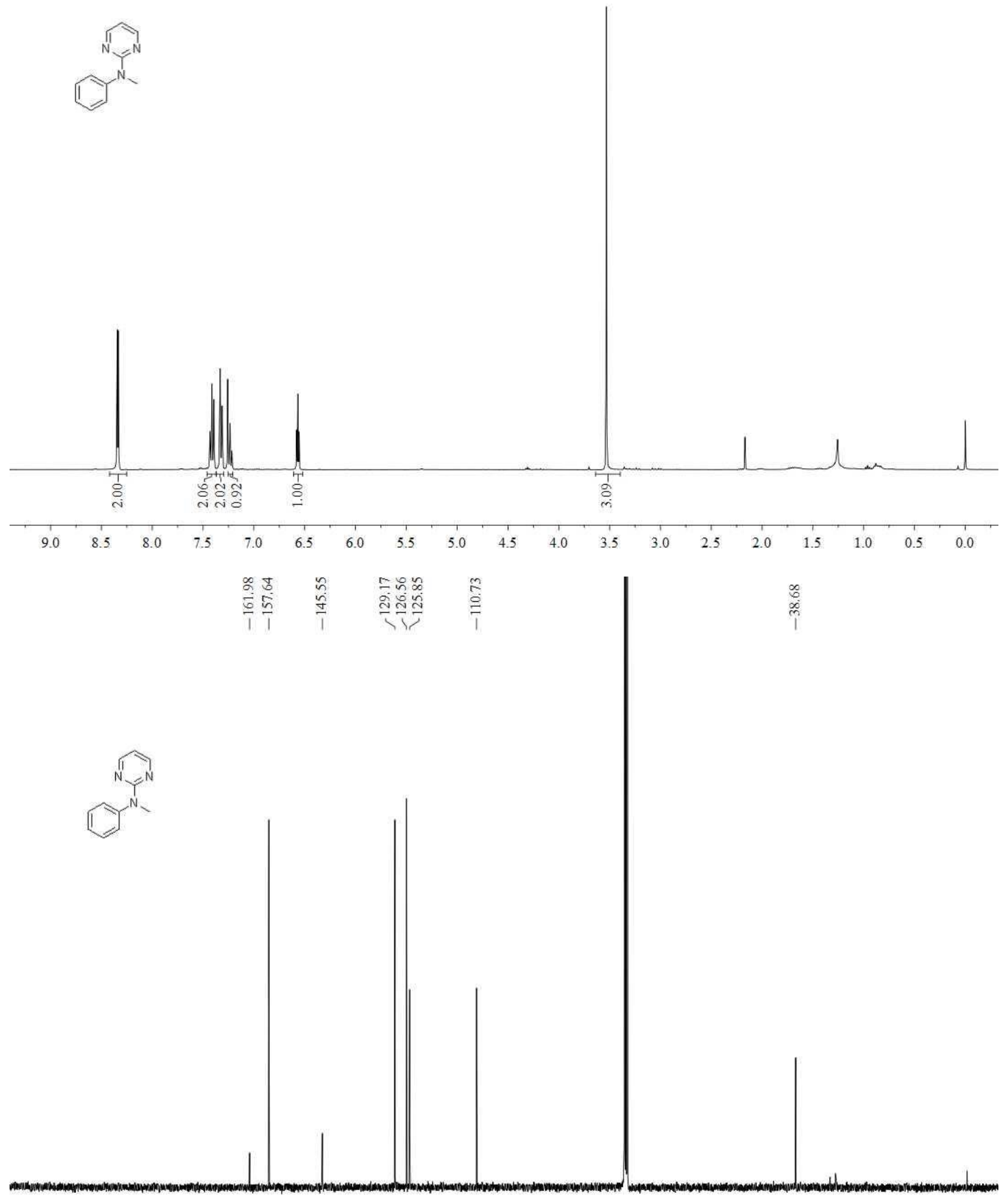

$\begin{array}{lllllllllllllllllllllll}1 & 210 & 200 & 190 & 180 & 170 & 160 & 150 & 140 & 130 & 120 & 110 & 100 & 90 & 80 & 70 & 60 & 50 & 40 & 30 & 20 & 10 & 0\end{array}$ 
$N$-methyl- $N$-phenylpyrazin-2-amine (9c)

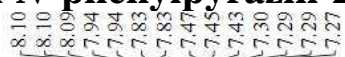

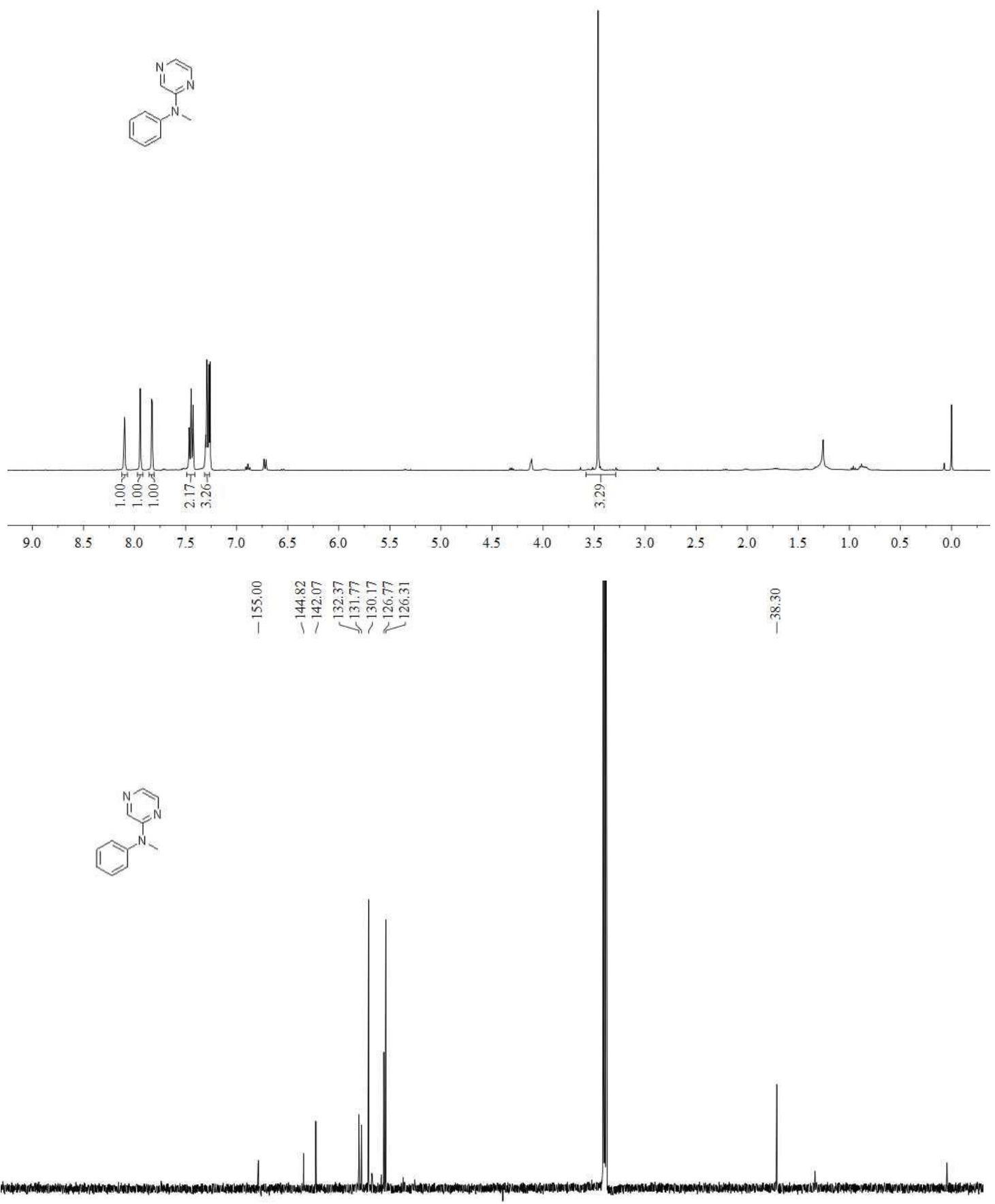


$N$-methyl- $N$-phenylpyridazin-3-amine (10c)

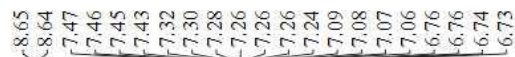
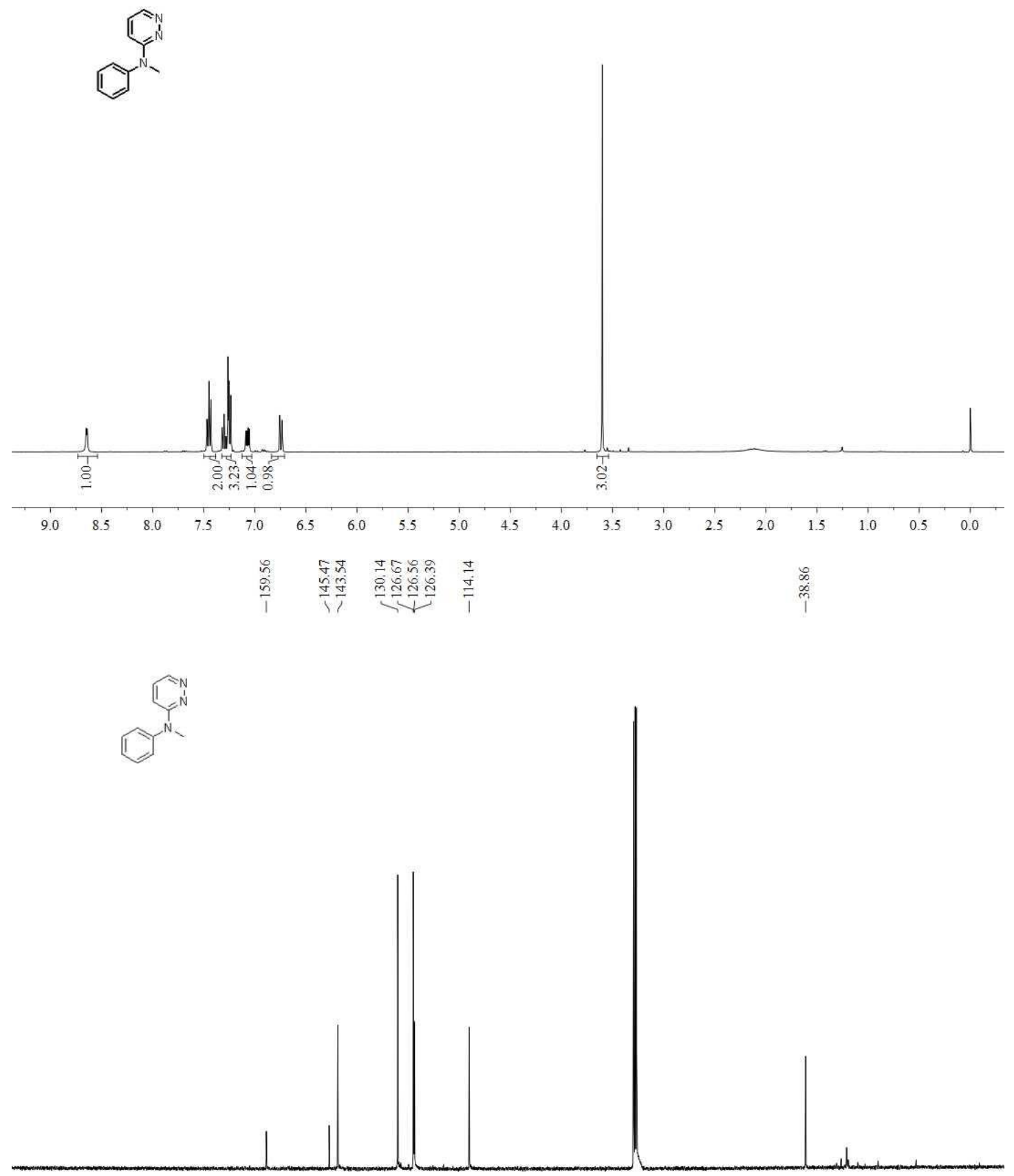

$\begin{array}{lllllllllllllllllllll}210 & 200 & 190 & 180 & 170 & 160 & 150 & 140 & 130 & 120 & 110 & 100 & 90 & 80 & 70 & 60 & 50 & 40 & 30 & 20 & 10\end{array}$ 


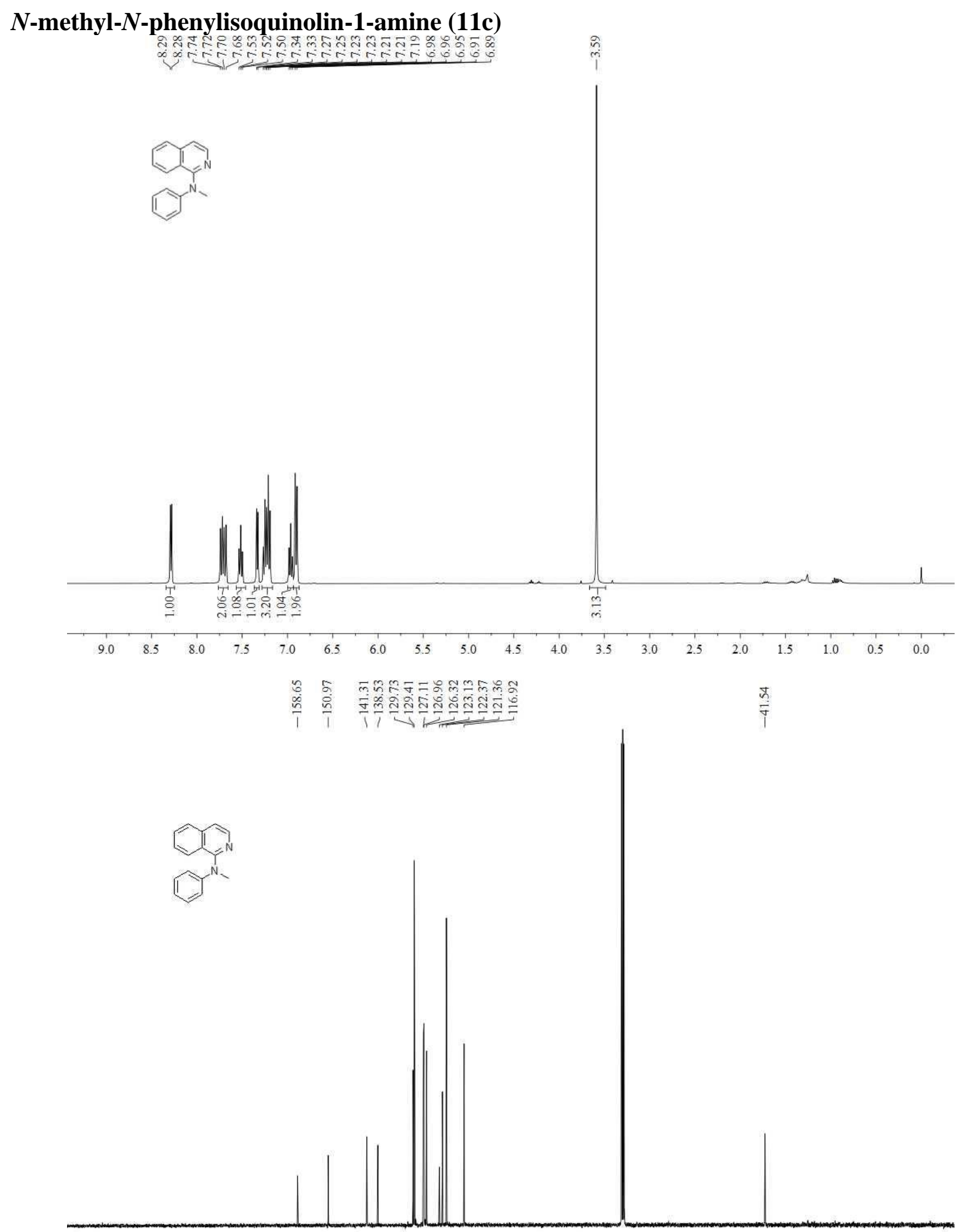

$\begin{array}{lllllllllllllllllllllllllll}210 & 200 & 190 & 180 & 170 & 160 & 150 & 140 & 130 & 120 & 110 & 100 & 90 & 80 & 70 & 60 & 50 & 40 & 30 & 20 & 10 & 0\end{array}$ 


\section{6-bromo- $N$-methyl- $N$-phenylisoquinolin-1-amine (12c)}

$\infty \pi$
$\infty$
$\infty$
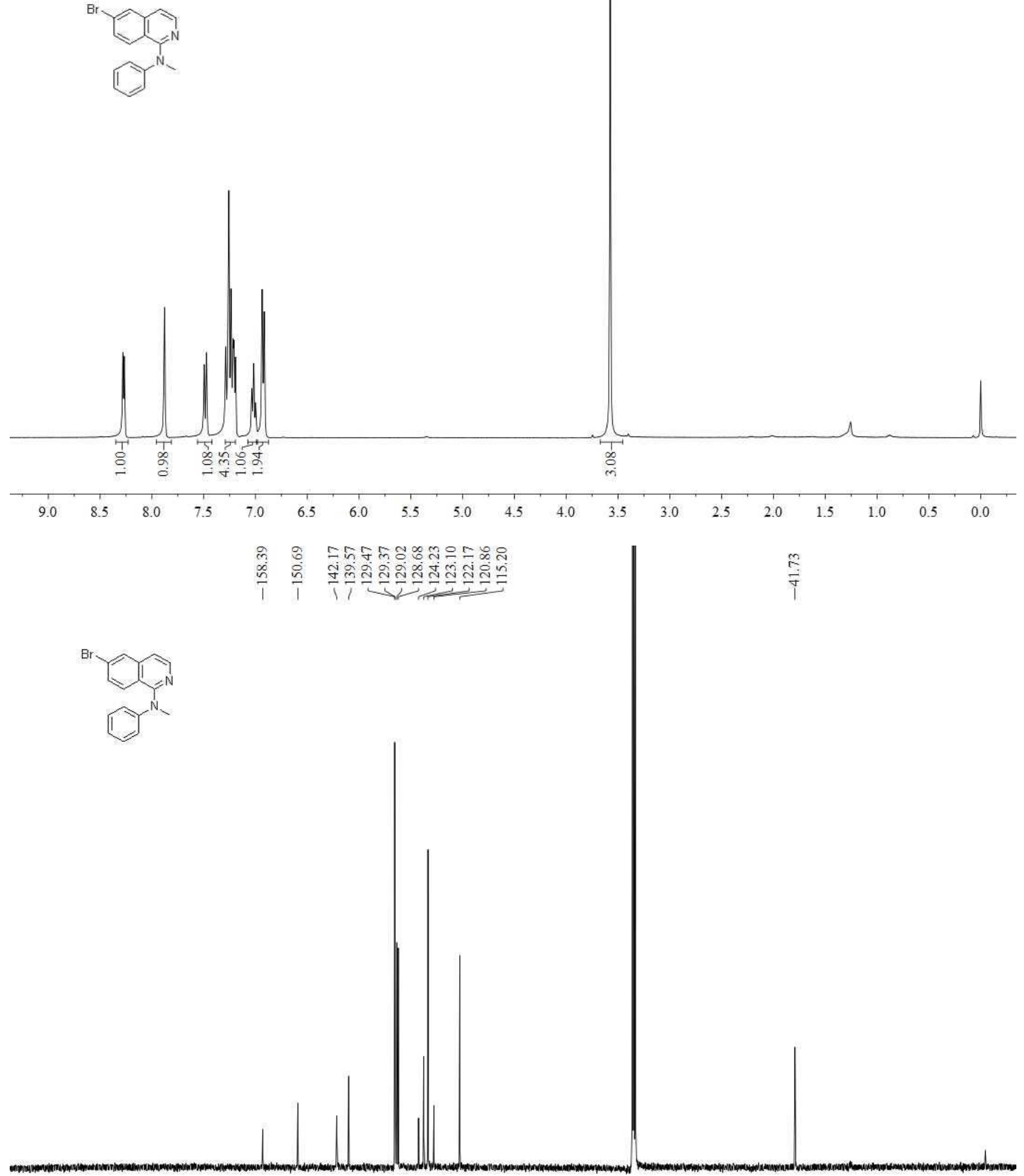

$\begin{array}{lllllllllllllllllllllll}210 & 200 & 190 & 180 & 170 & 160 & 150 & 140 & 130 & 120 & 110 & 100 & 90 & 80 & 70 & 60 & 50 & 40 & 30 & 20 & 10 & 0\end{array}$ 


\section{$N$-methyl- $N$-phenylquinolin-2-amine (13c)}

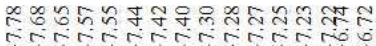
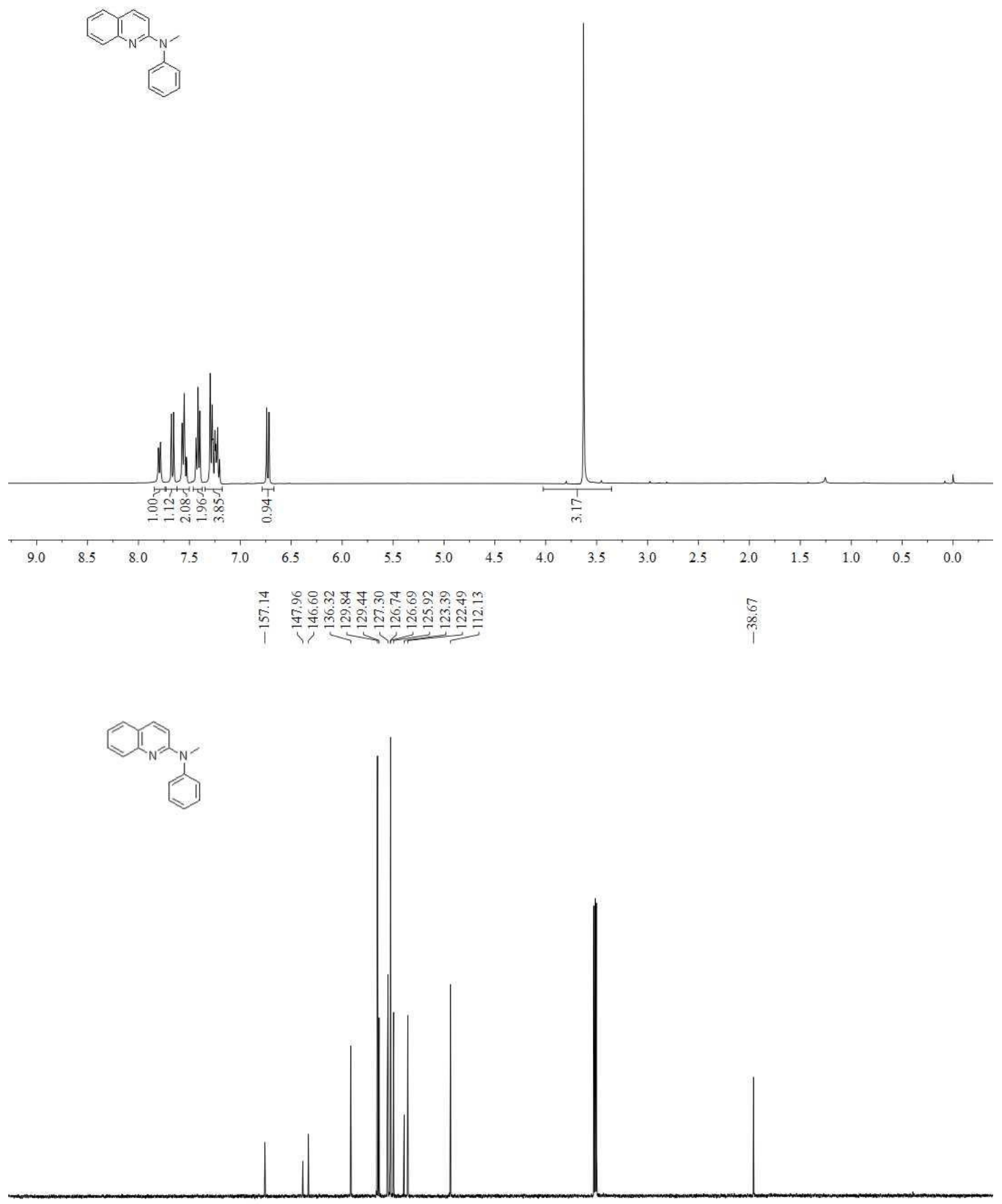

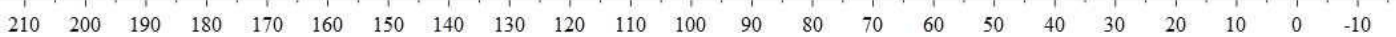


6-bromo- $N$-methyl- $N$-phenylquinolin-2-amine (14c)

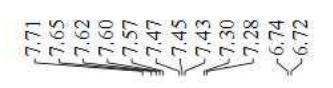

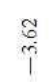
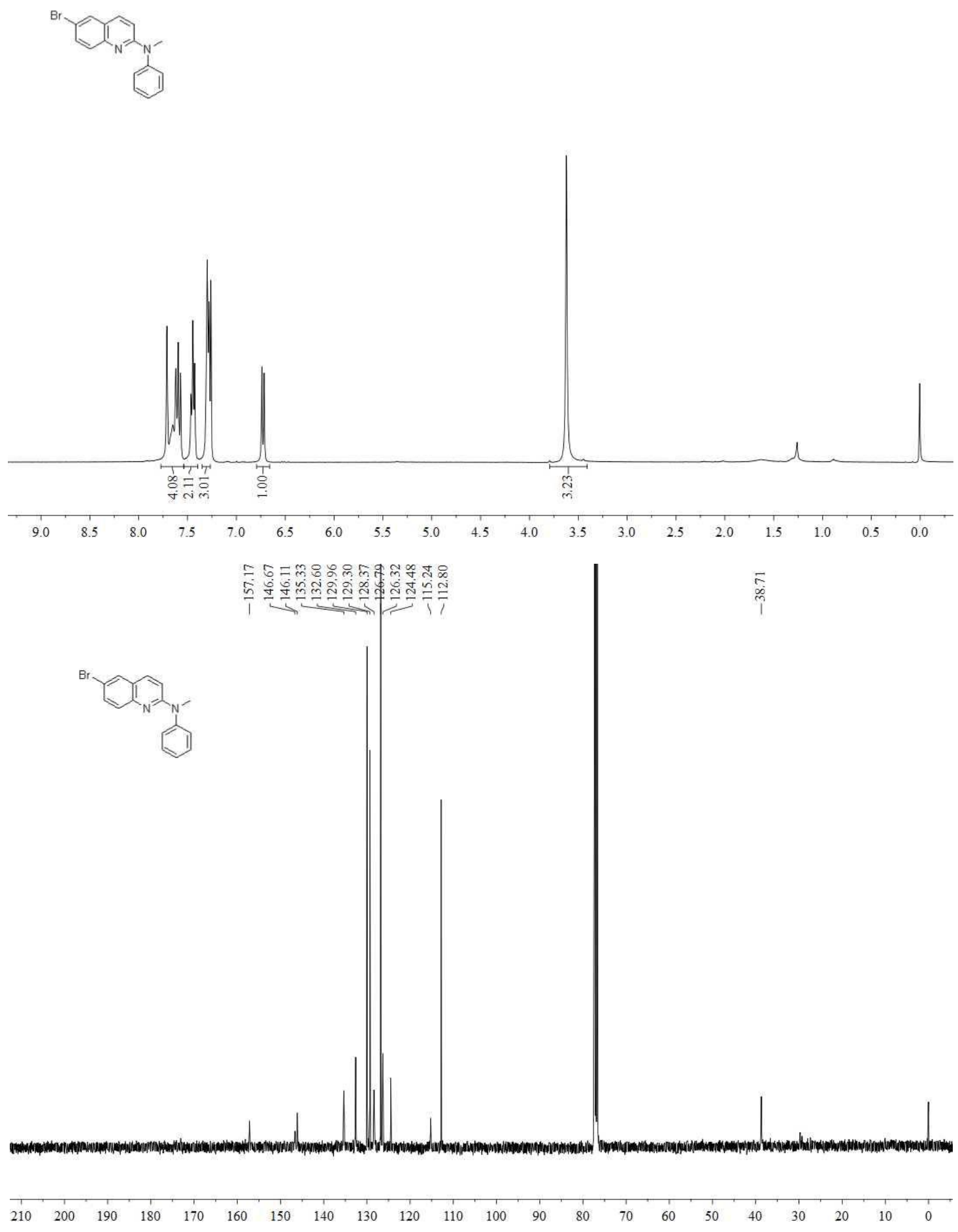

72 


\section{$N$,4-dimethyl- $N$-phenylquinolin-2-amine (15c)}

monsing

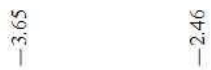

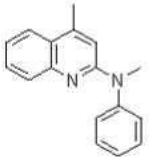

(1)
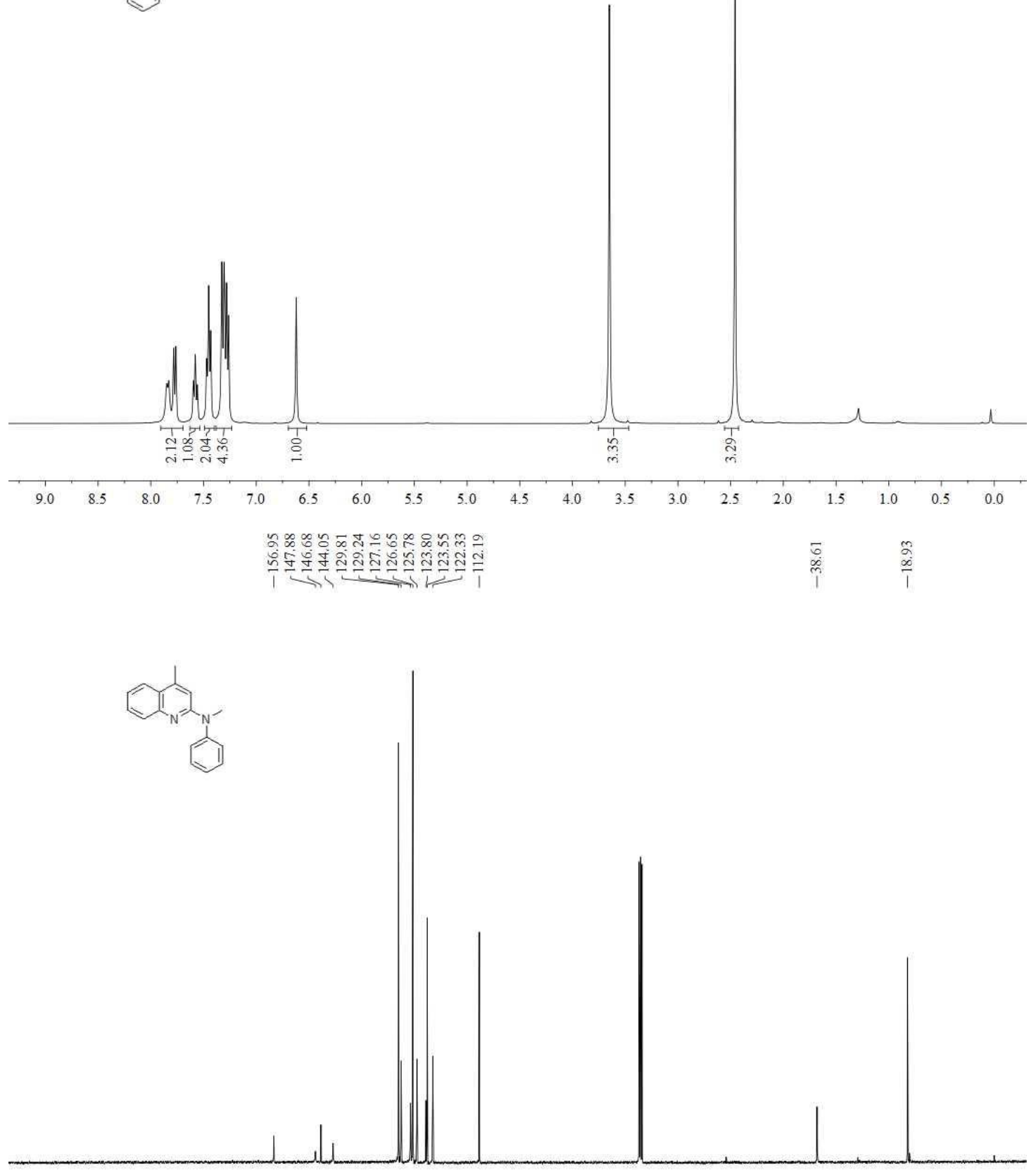

$\begin{array}{llllllllllllllllllllll}210 & 200 & 190 & 180 & 170 & 160 & 150 & 140 & 130 & 120 & 110 & 100 & 90 & 80 & 70 & 60 & 50 & 40 & 30 & 20 & 10 & 0\end{array}$ 
$N$-methyl- $N$-phenylquinolin-4-amine (16c)

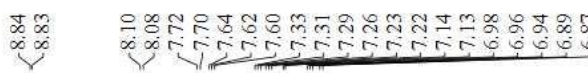

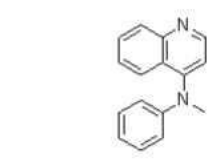
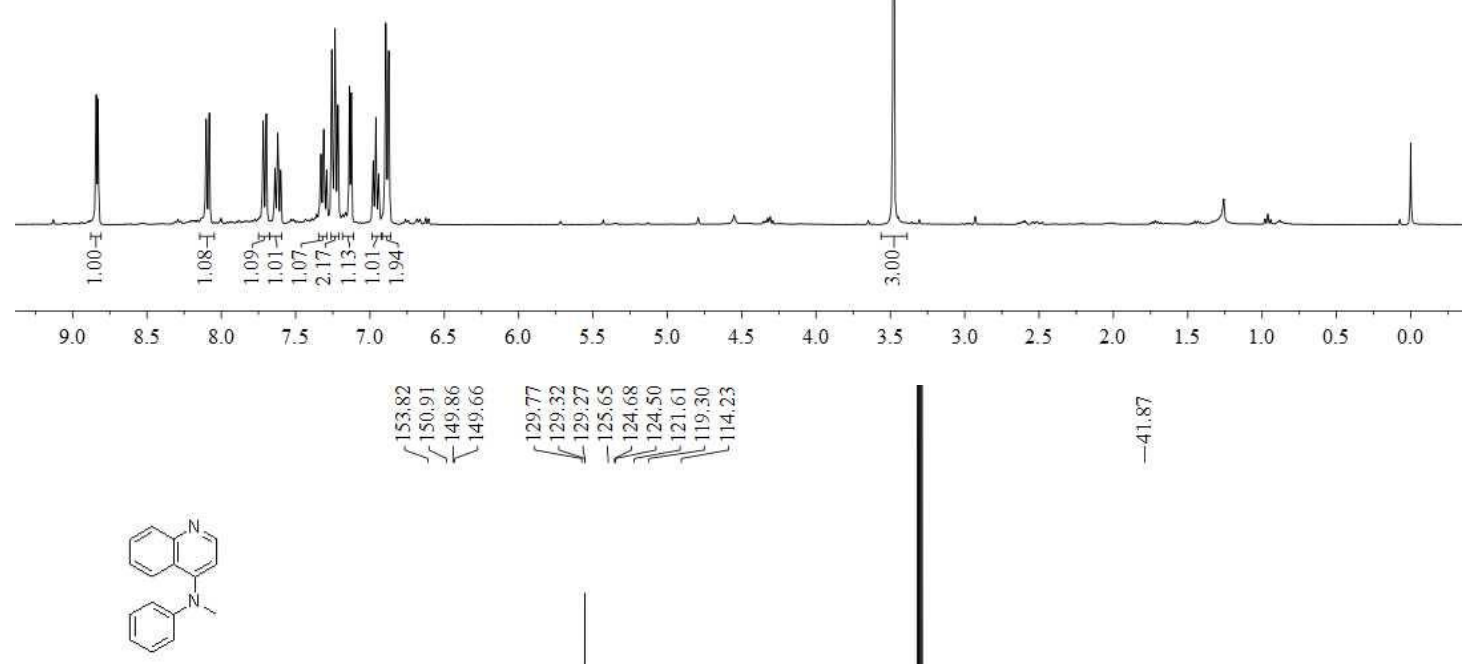

$\theta^{N}$

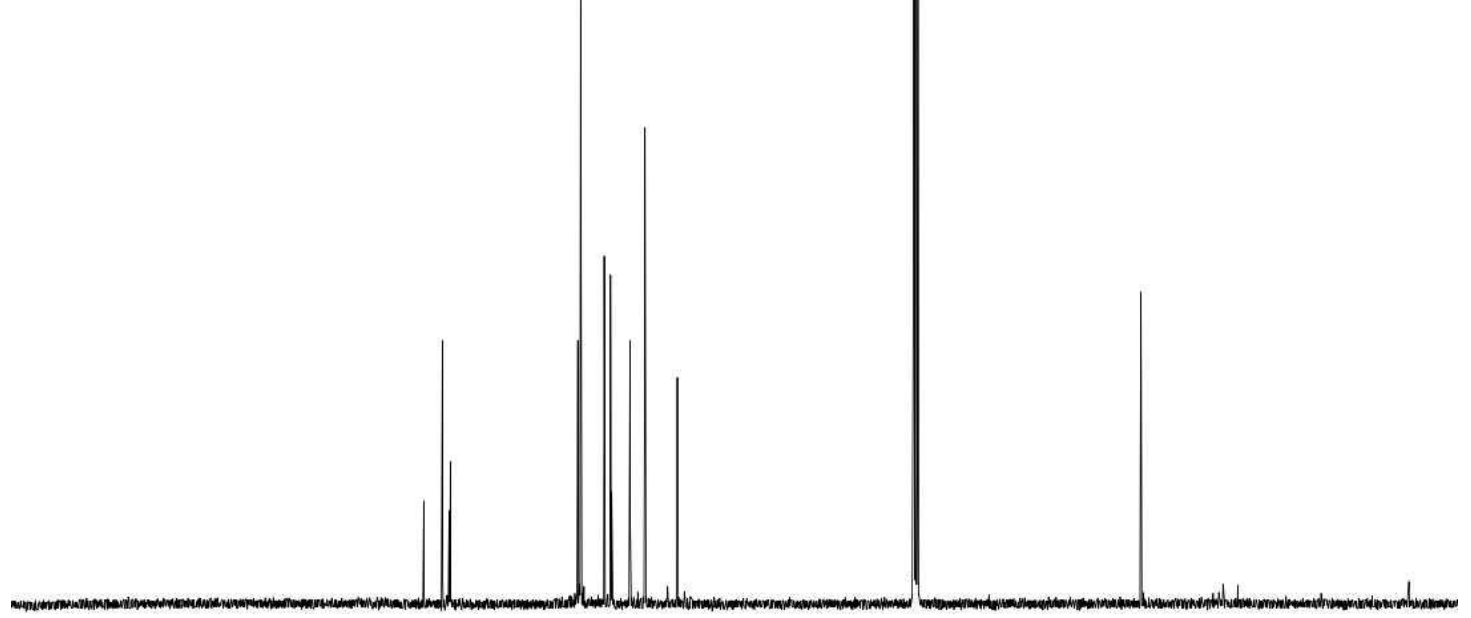

$\begin{array}{lllllllllllllllllllllll}1 & 110 & 200 & 190 & 180 & 170 & 160 & 150 & 140 & 130 & 120 & 110 & 100 & 90 & 80 & 70 & 60 & 50 & 40 & 30 & 20 & 10 & 0\end{array}$ 
$N$-methyl- $N$-(p-tolyl)isoquinolin-1-amine (17c)

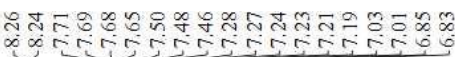

in
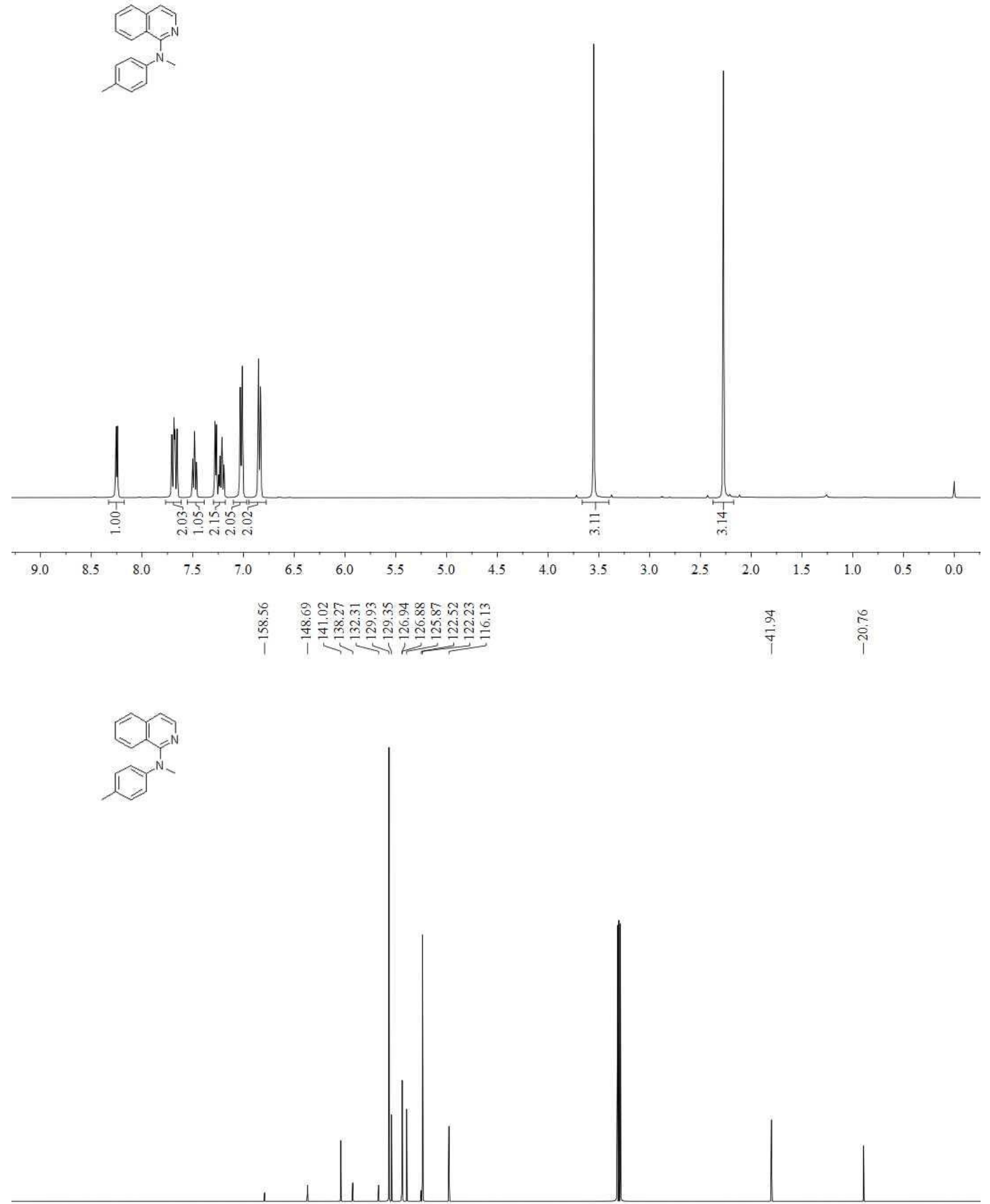


\section{$N$-(4-methoxyphenyl)- $N$-methylisoquinolin-1-amine (18c)}
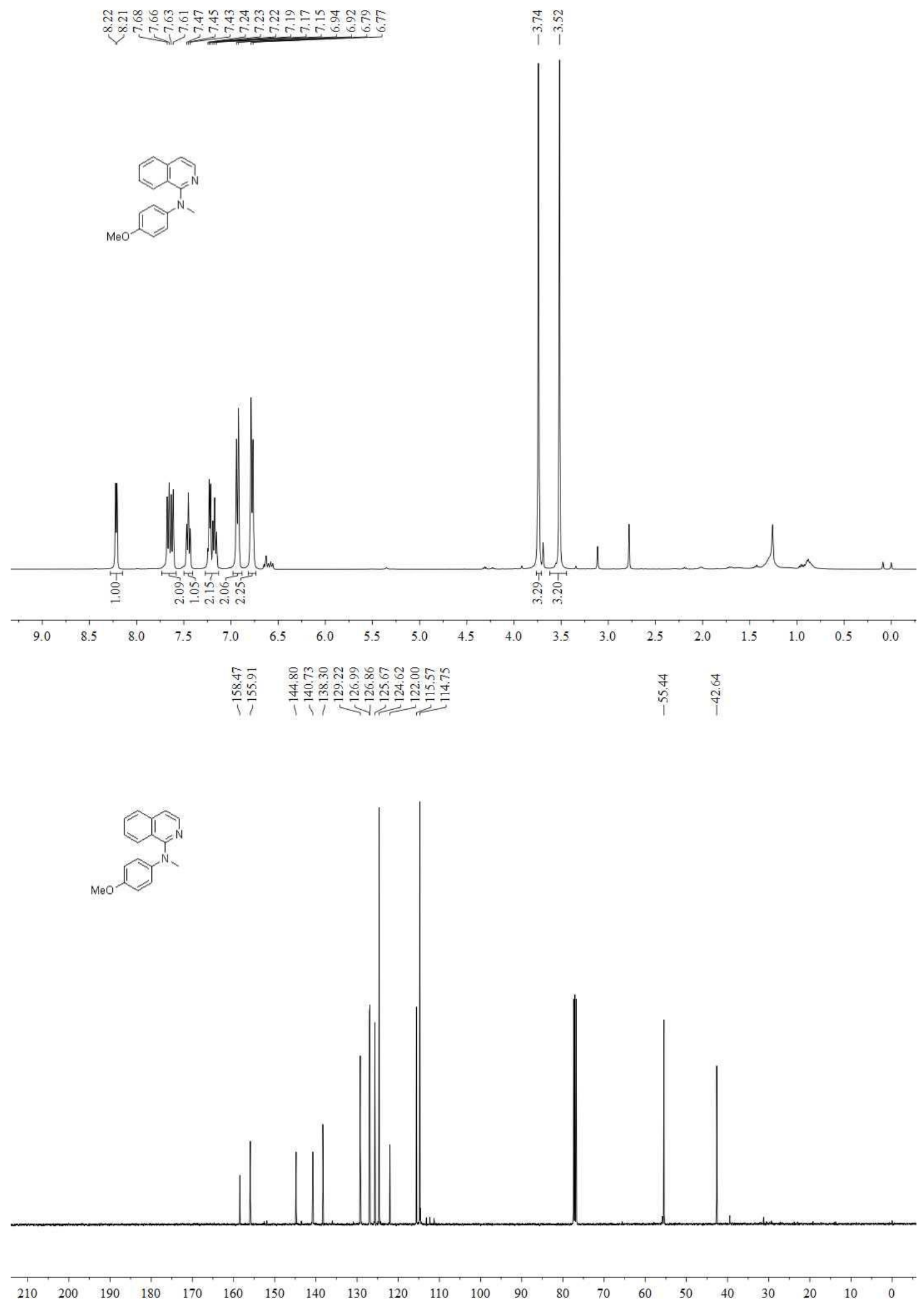


\section{$N$-(4-fluorophenyl)- $N$-methylisoquinolin-1-amine (19c)}
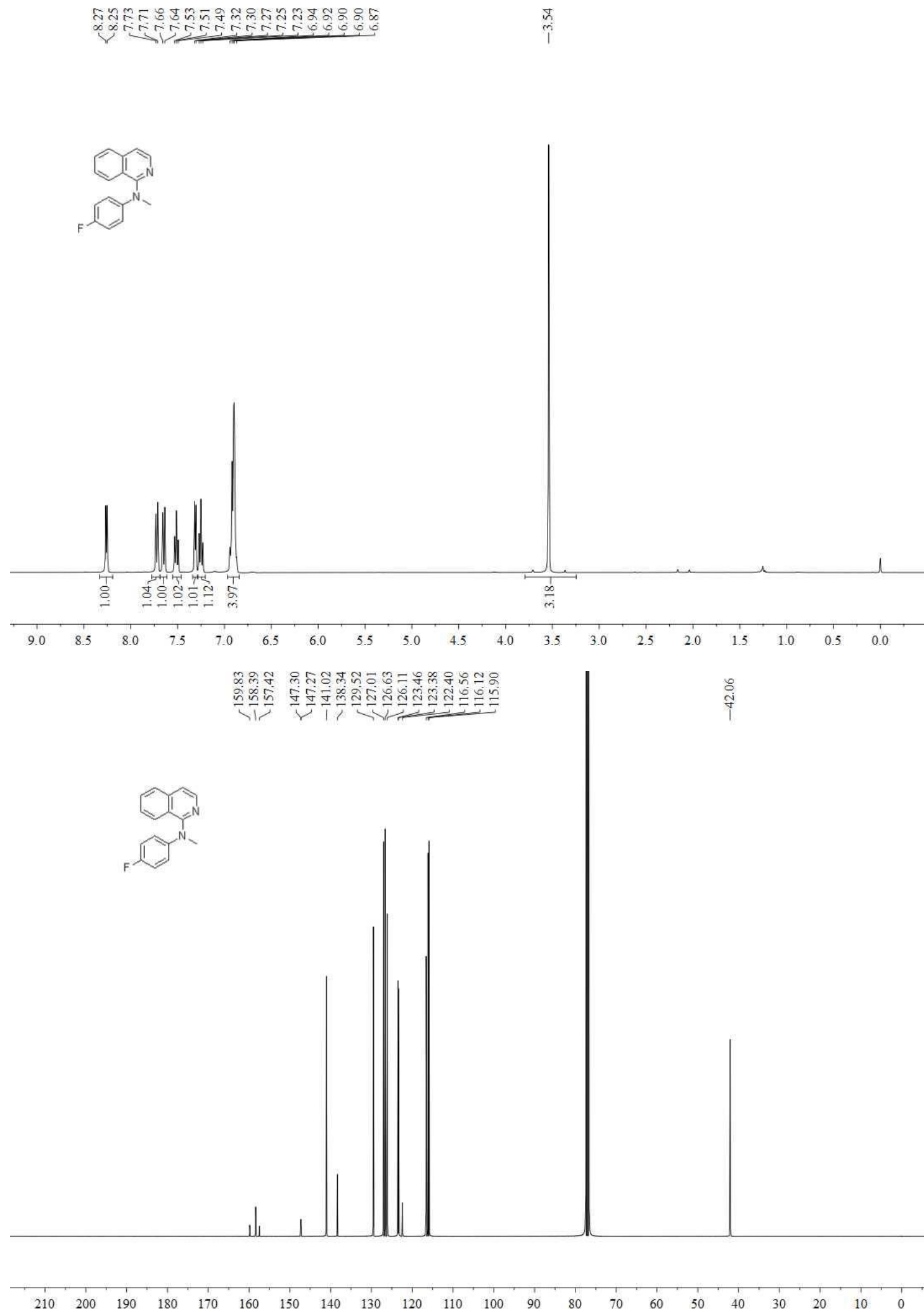


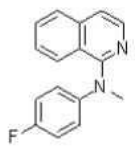
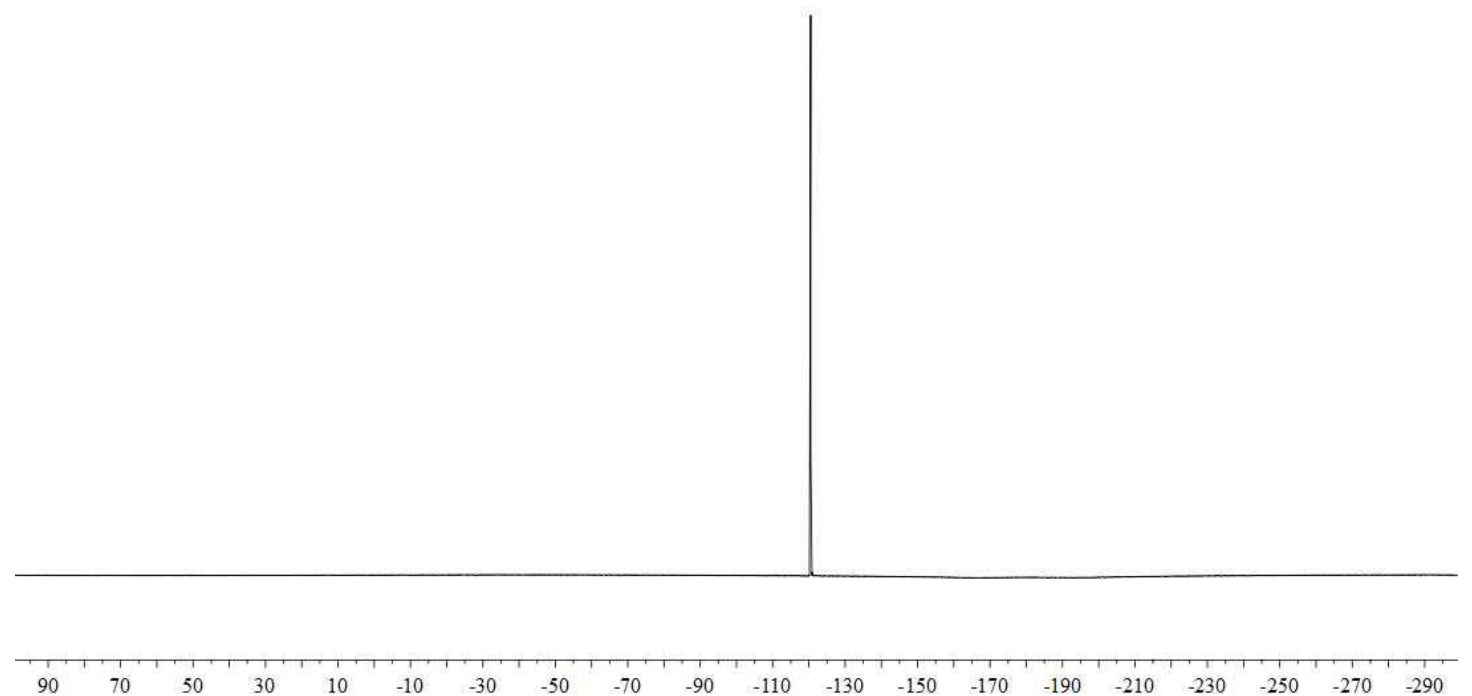
$N$-(4-chlorophenyl)- $N$-methylisoquinolin-1-amine (20c)

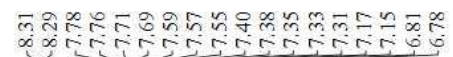

$\stackrel{\stackrel{m}{i}}{i}$

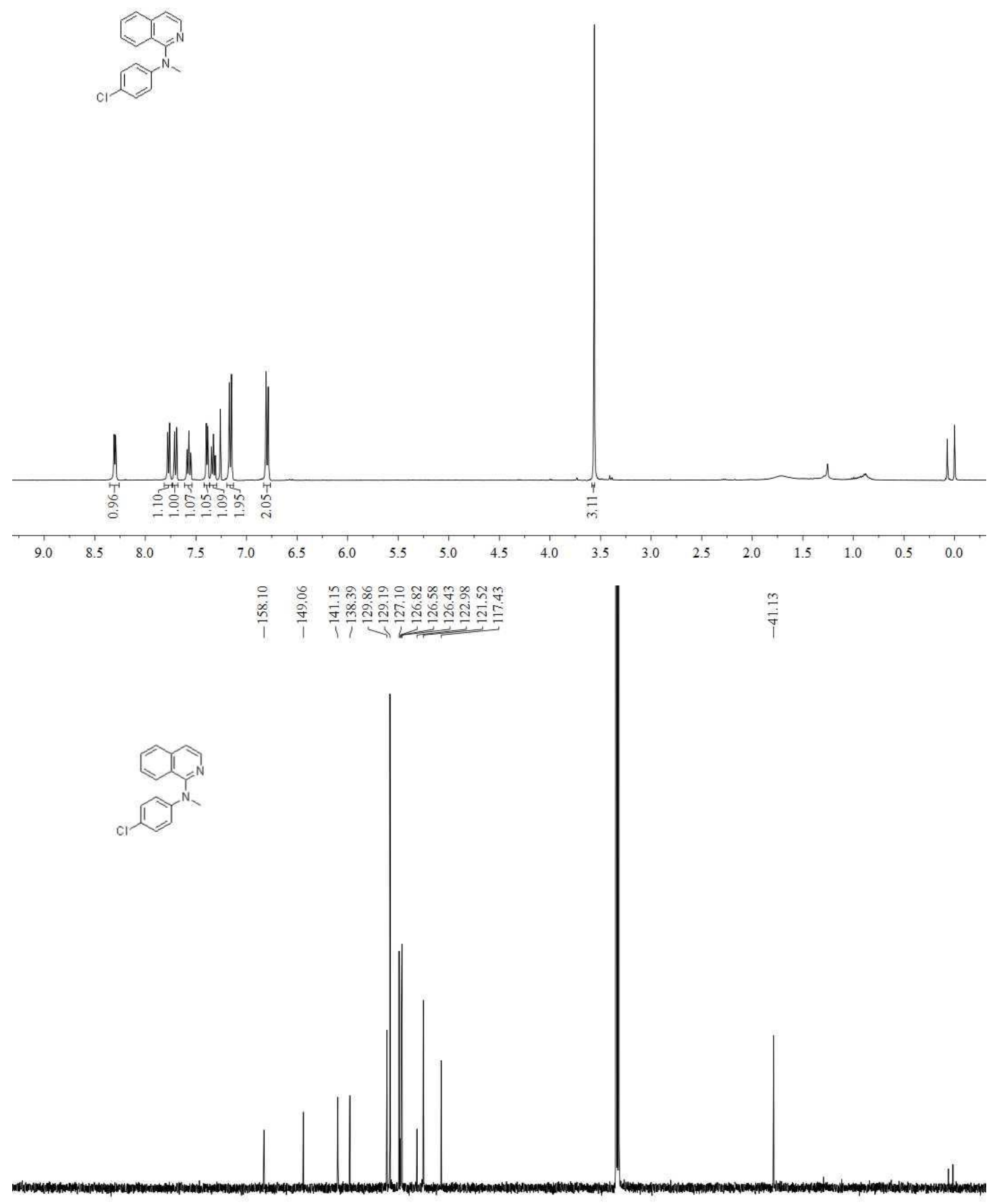

$\begin{array}{llllllllllllllllllllll}210 & 200 & 190 & 180 & 170 & 160 & 150 & 140 & 130 & 120 & 110 & 100 & 90 & 80 & 70 & 60 & 50 & 40 & 30 & 20 & 10 & 0\end{array}$ 
$N$-ethyl- $N$-phenylisoquinolin-1-amine (21c)

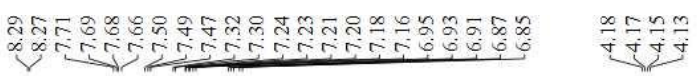

개유
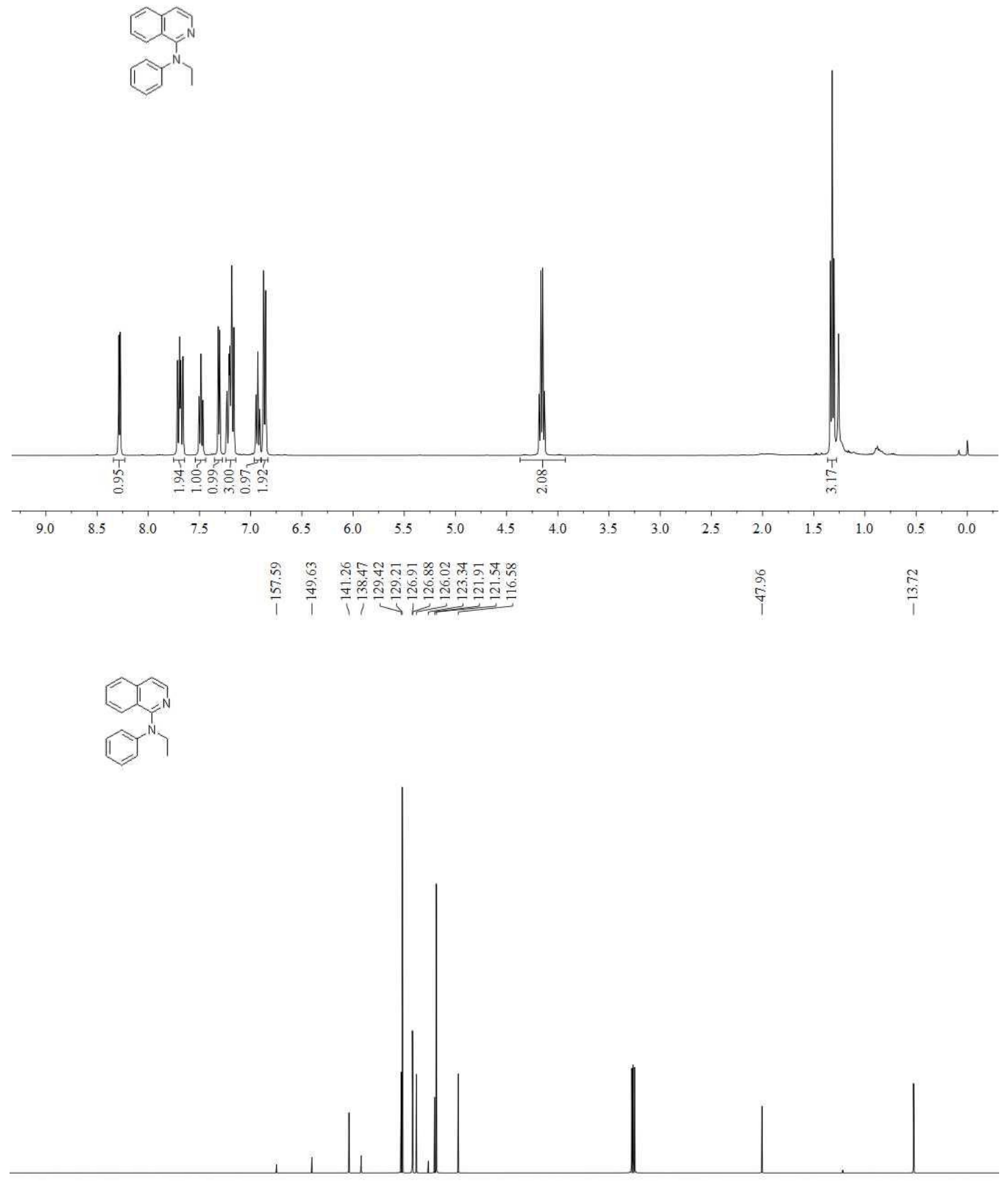

$\begin{array}{lllllllllllllllllllllllllll}210 & 200 & 190 & 180 & 170 & 160 & 150 & 140 & 130 & 120 & 110 & 100 & 90 & 80 & 70 & 60 & 50 & 40 & 30 & 20 & 10 & 0\end{array}$ 
$N$-phenyl-N-propylisoquinolin-1-amine (22c)

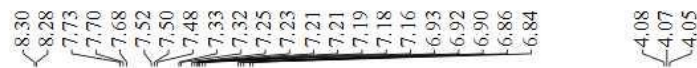

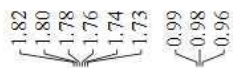
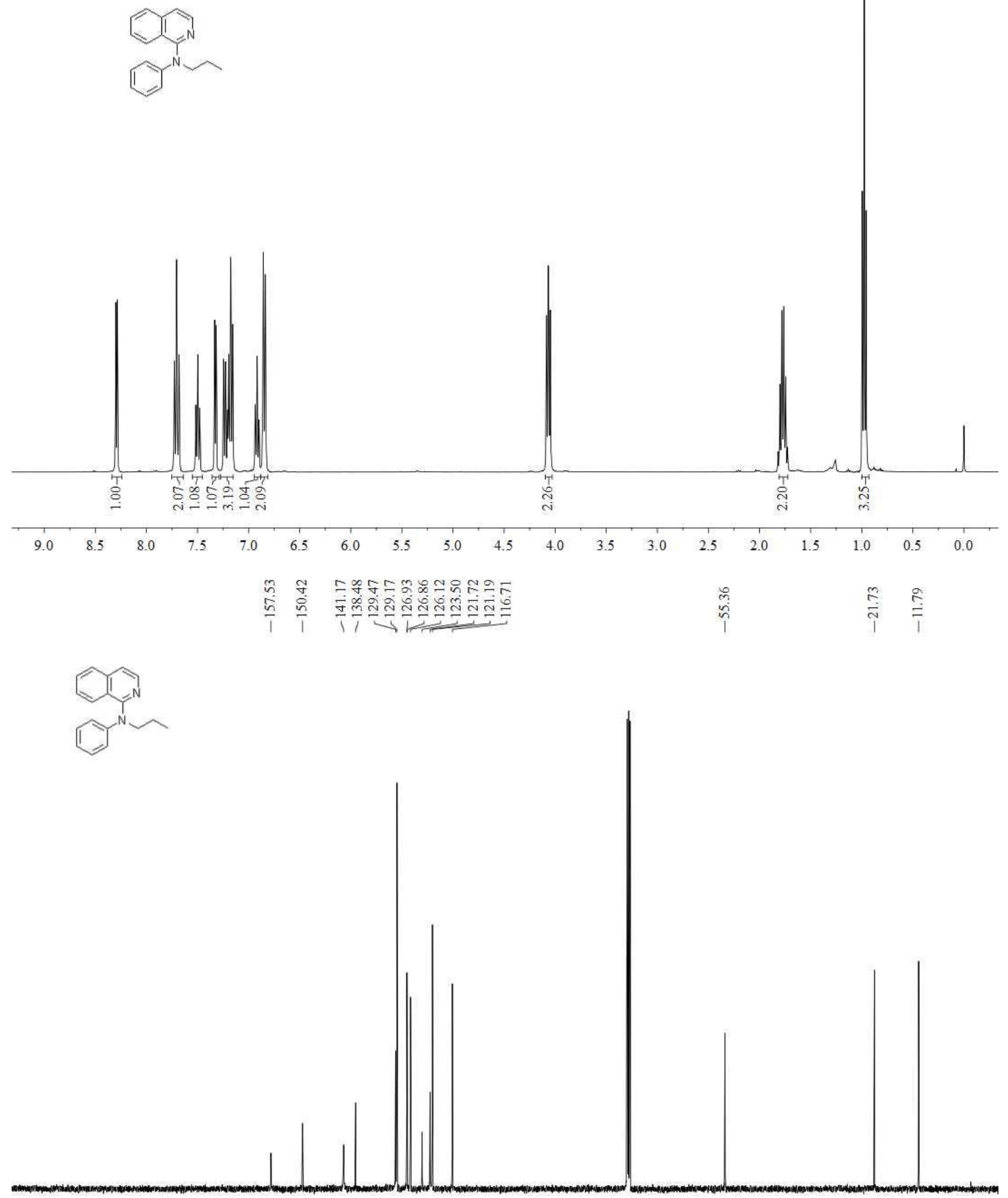

$\begin{array}{llllllllllllllllllllllllll}210 & 200 & 190 & 180 & 170 & 160 & 150 & 140 & 130 & 120 & 110 & 100 & 90 & 80 & 70 & 60 & 50 & 40 & 30 & 20 & 10 & 0\end{array}$ 


\section{$N$-isopropyl- $N$-phenylisoquinolin-1-amine (23c)}

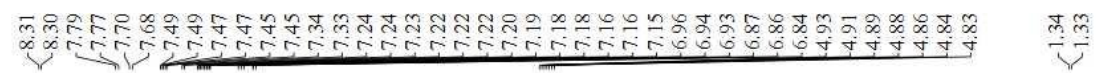
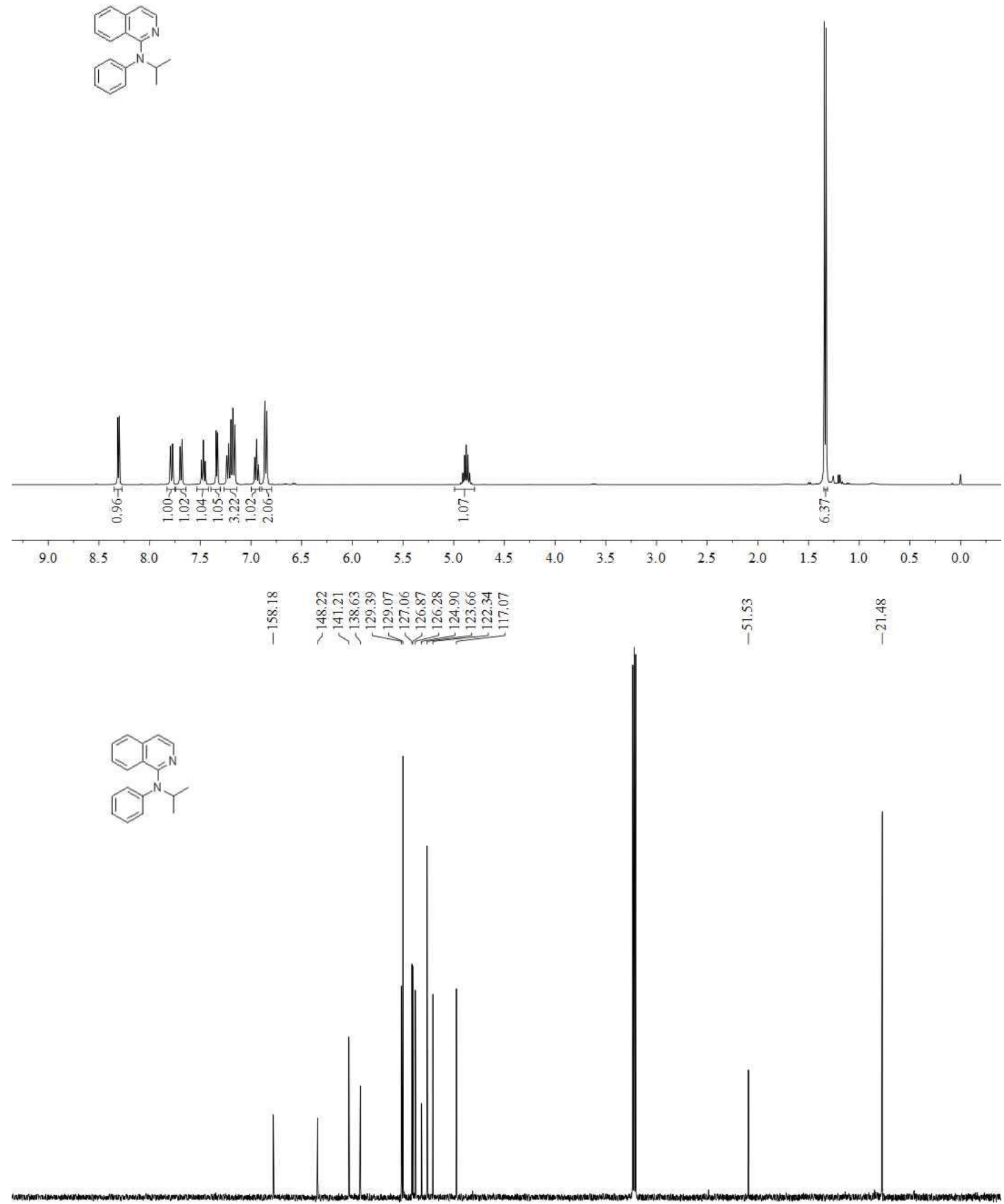
$N$-cyclohexyl- $N$-phenylisoquinolin-1-amine (24c)

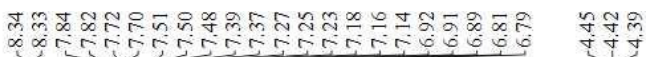

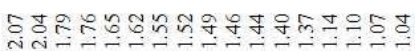
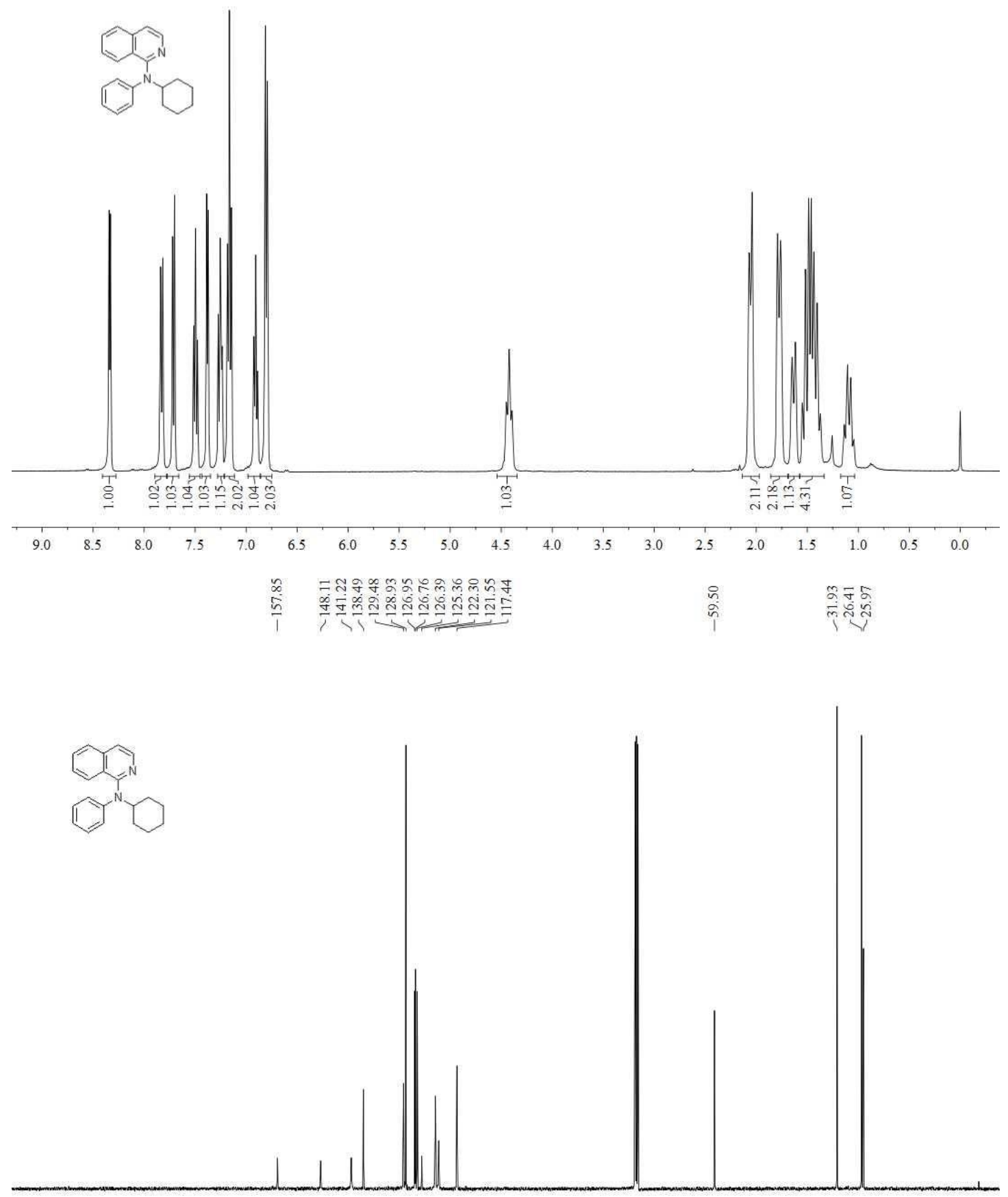

$\begin{array}{lllllllllllllllllllll}210 & 200 & 190 & 180 & 170 & 160 & 150 & 140 & 130 & 120 & 110 & 100 & 90 & 80 & 70 & 60 & 50 & 40 & 30 & 20 & 10\end{array}$ 


\section{1-(isoquinolin-1-yl)-1,2,3,4-tetrahydroquinoline (25c)}

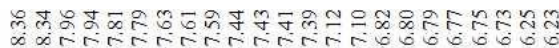
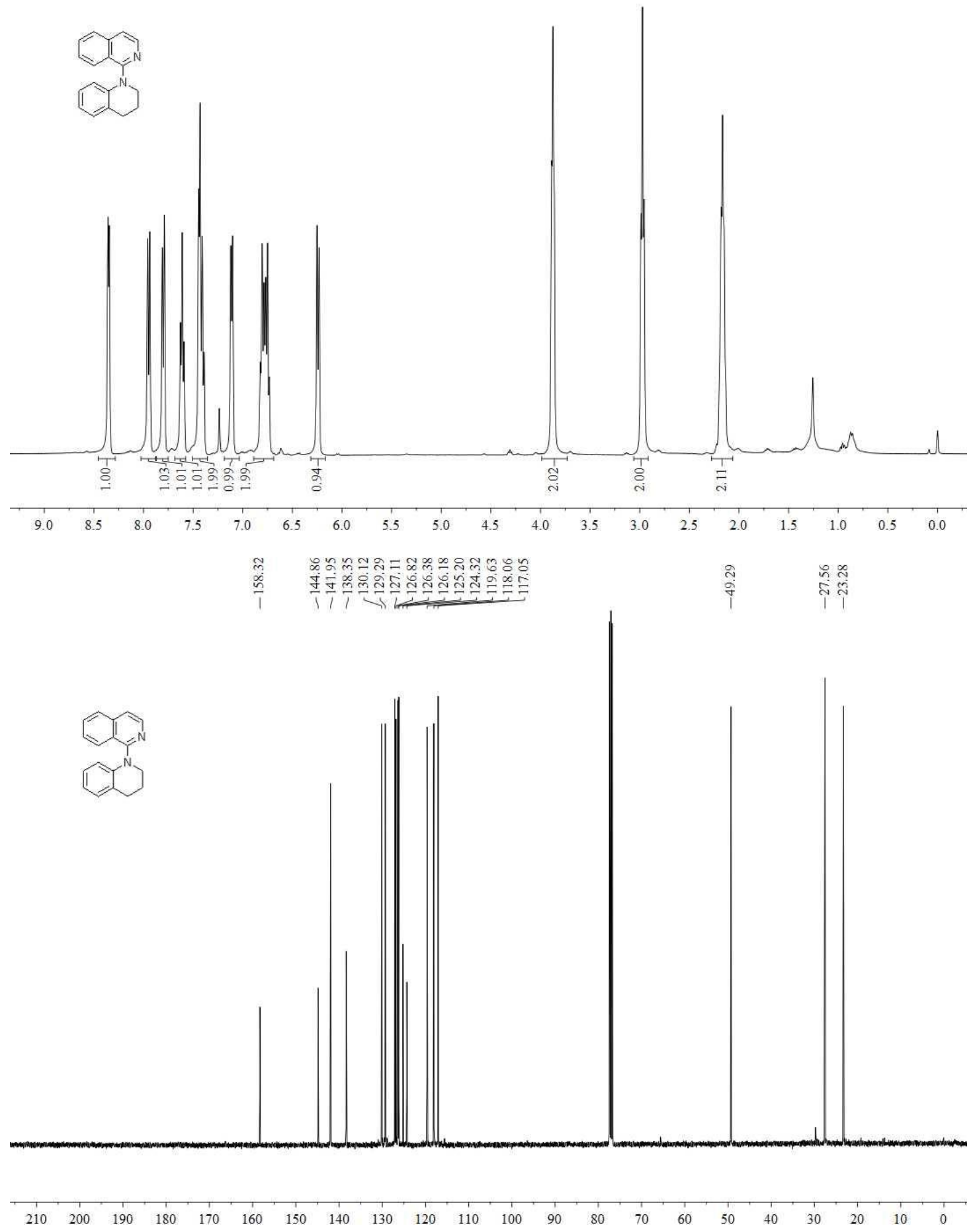


\section{$N$-benzyl- $N$-phenylisoquinolin-1-amine (26c)}

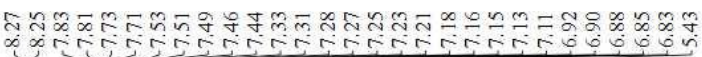
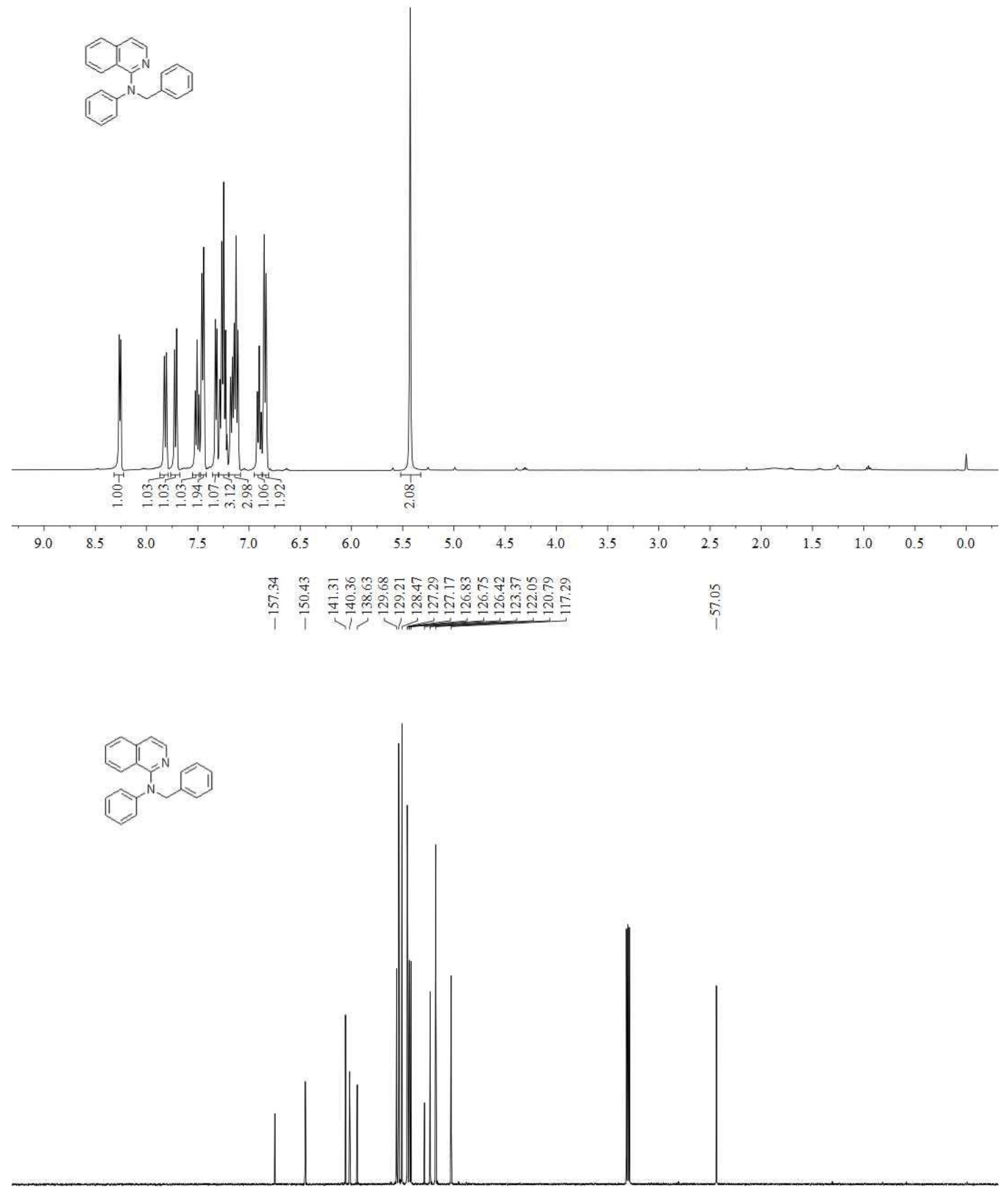


\section{$N, N$-diphenylisoquinolin-1-amine (27c)}

mos
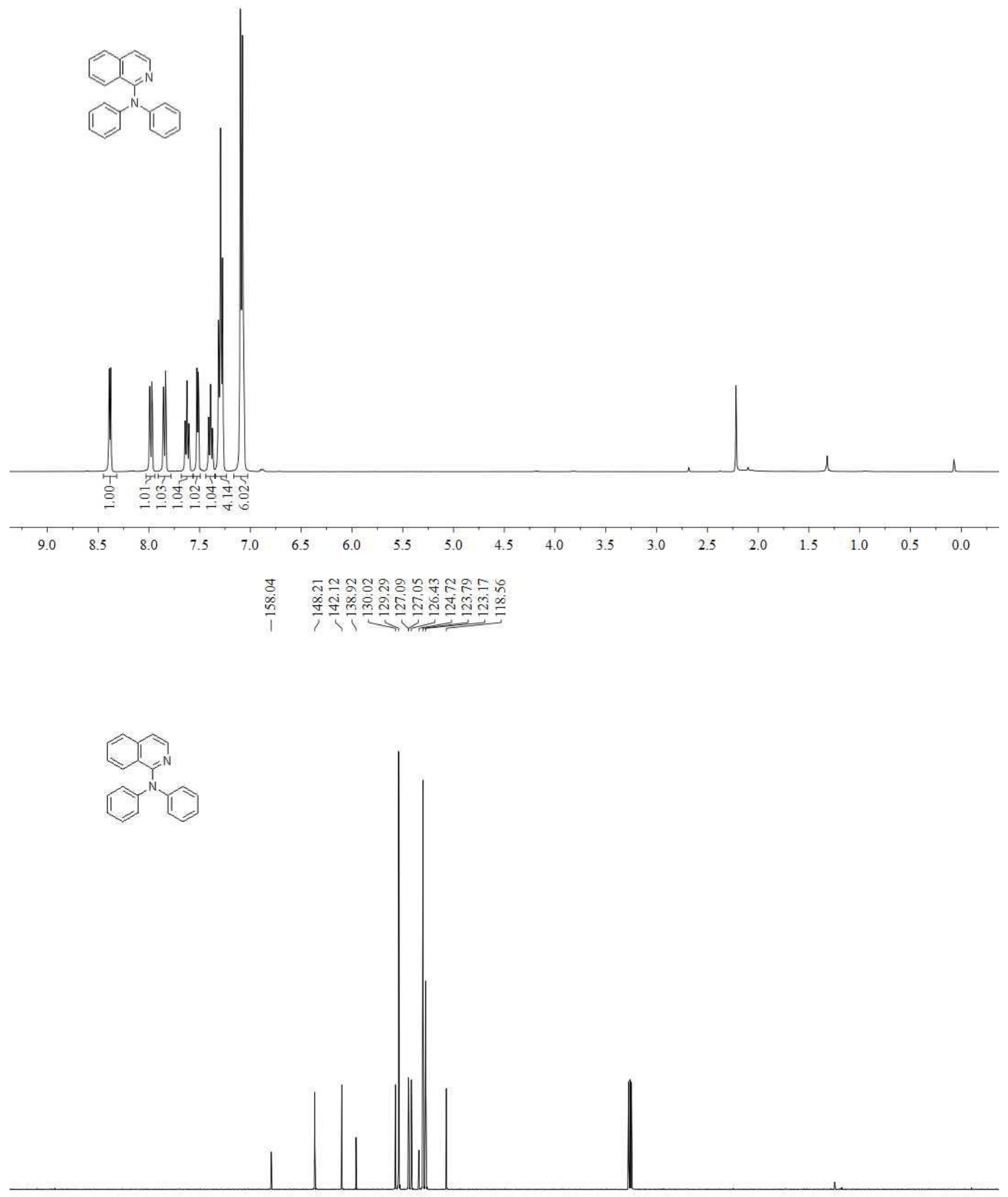

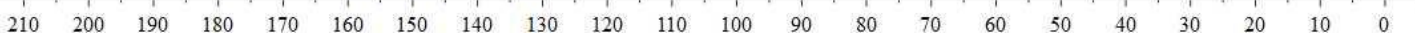


3-(isoquinolin-1-yl(phenyl)amino)propanenitrile (28c)

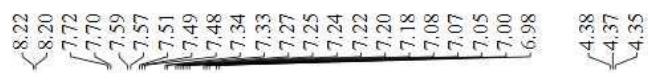

$\underbrace{\substack{\infty \\ j}}_{\substack{\infty \rightarrow \infty \\ \text { jid }}}$
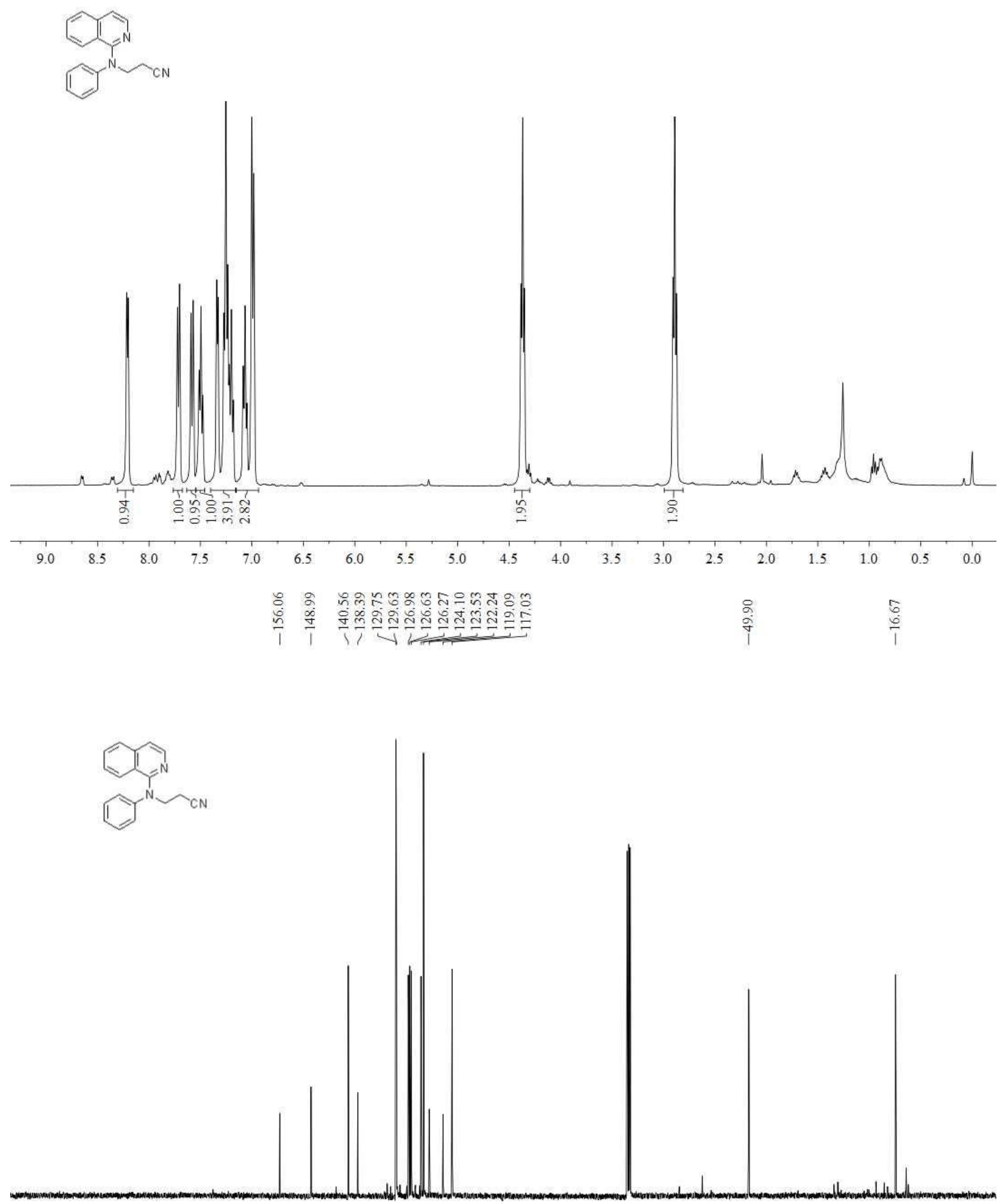

$\begin{array}{lllllllllllllllllllll}210 & 200 & 190 & 180 & 170 & 160 & 150 & 140 & 130 & 120 & 110 & 100 & 90 & 80 & 70 & 60 & 50 & 40 & 30 & 20 & 10\end{array}$ 


\section{2-(isoquinolin-1-yl(phenyl)amino)ethanol (29c)}

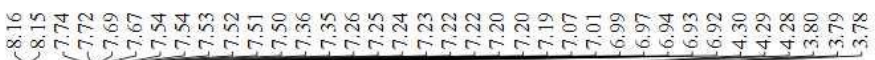

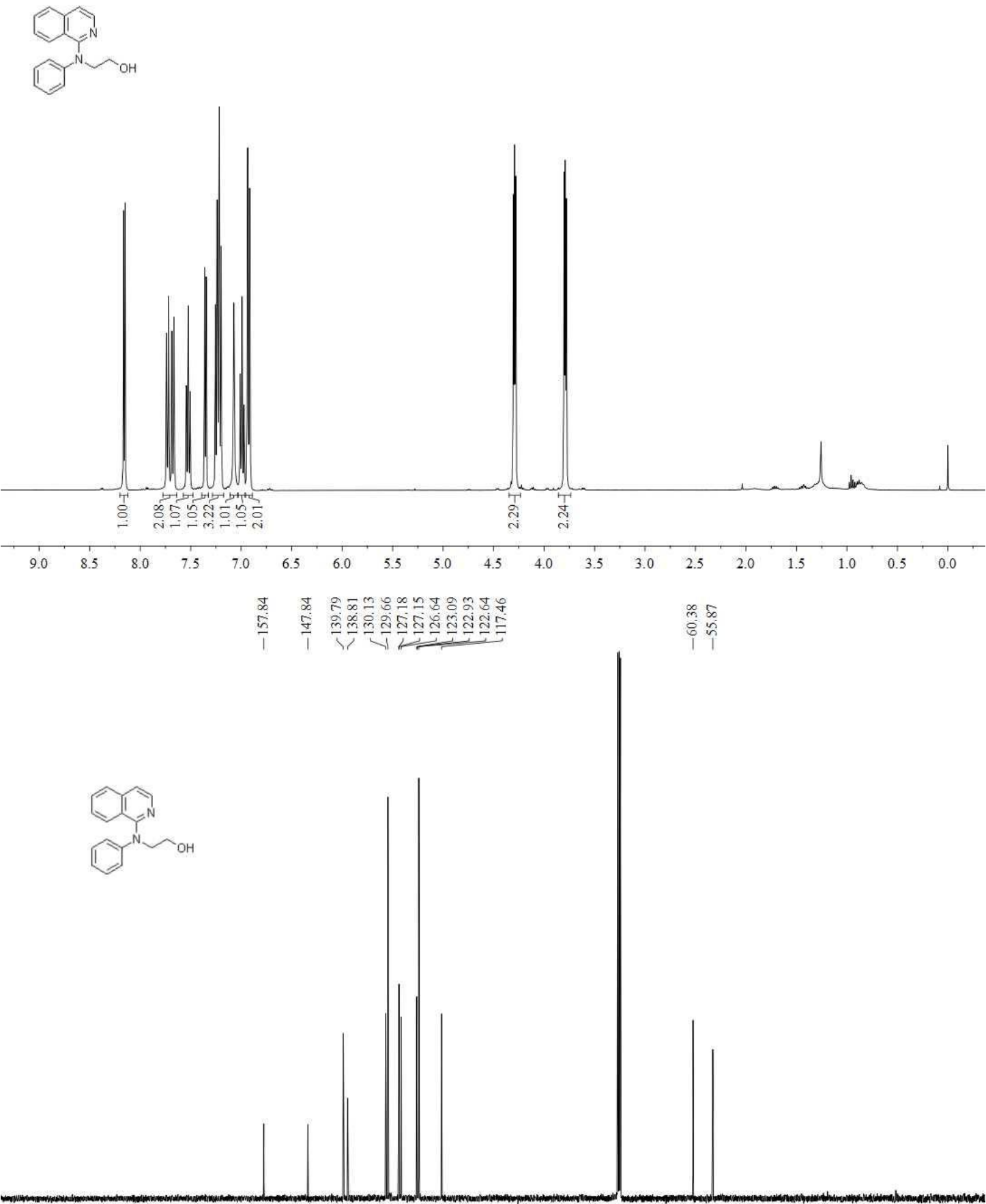

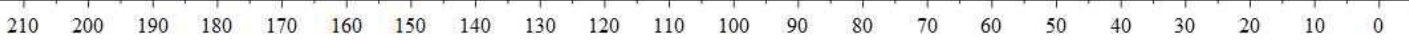


Methyl 3-(isoquinolin-1-yl(phenyl)amino)propanoate (30c)

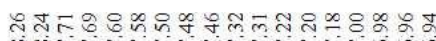

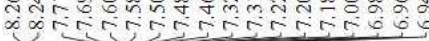

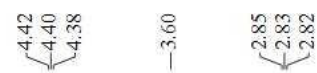

11

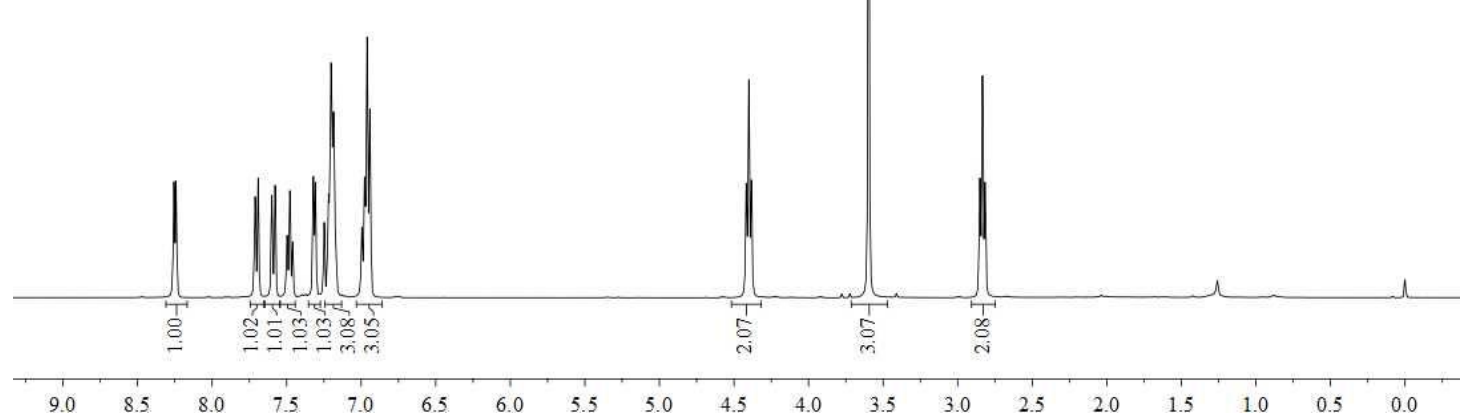

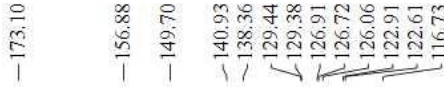

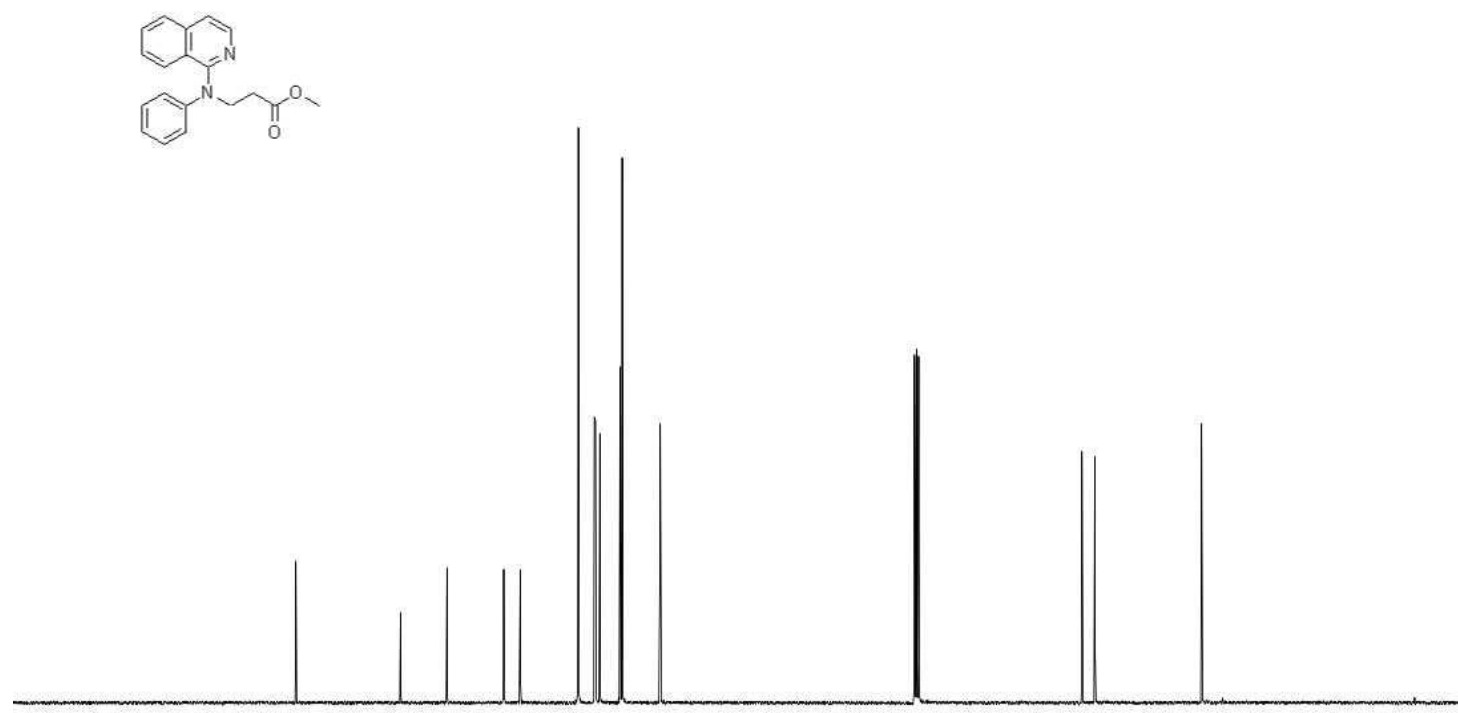

$\begin{array}{llllllllllllllllllllll}210 & 200 & 190 & 180 & 170 & 160 & 150 & 140 & 130 & 120 & 110 & 100 & 90 & 80 & 70 & 60 & 50 & 40 & 30 & 20 & 10 & 0\end{array}$ 


\section{$N$-allyl- $N$-phenylisoquinolin-1-amine (31c)}

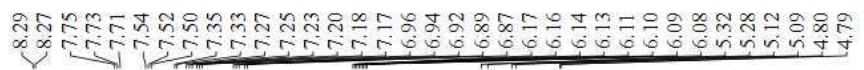
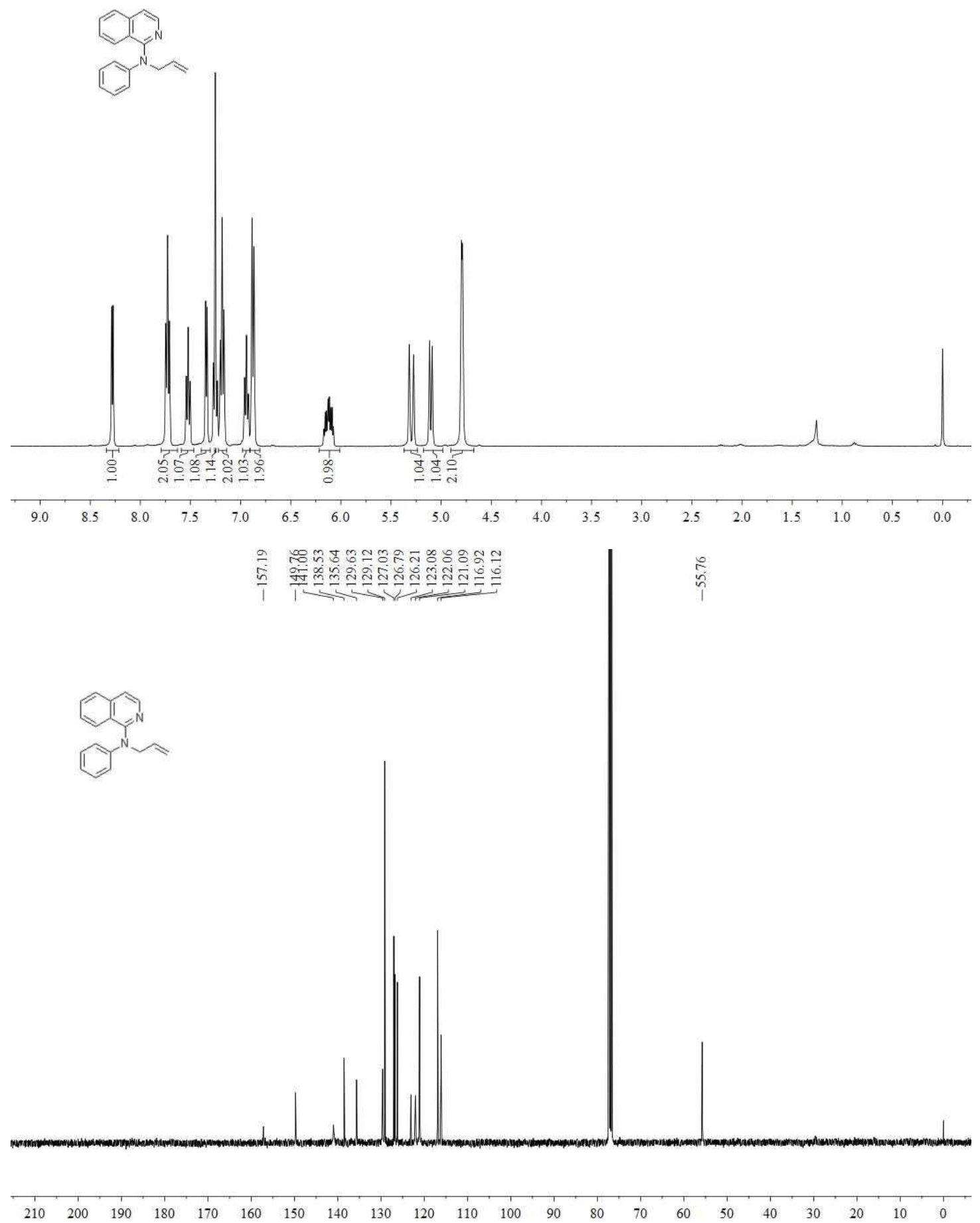


\section{$N$-(but-3-yn-1-yl)- $N$-phenylisoquinolin-1-amine (32c)}

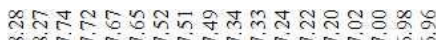

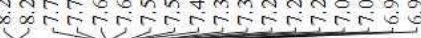

m̧m户

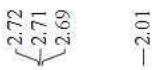
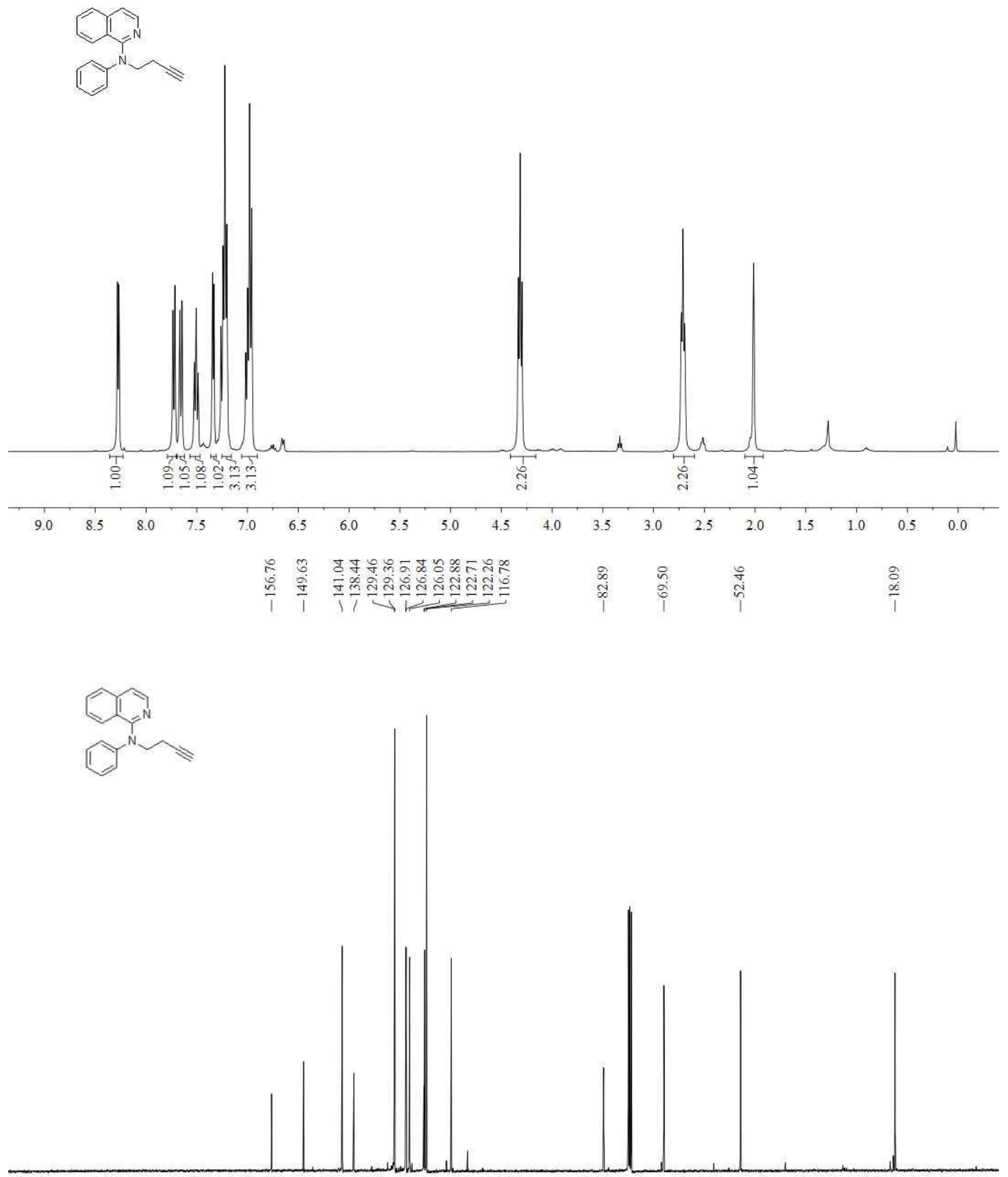

$\begin{array}{llllllllllllllllllllll}210 & 200 & 190 & 180 & 170 & 160 & 150 & 140 & 130 & 120 & 110 & 100 & 90 & 80 & 70 & 60 & 50 & 40 & 30 & 20 & 10 & 0\end{array}$ 


\section{$\mathrm{N}$-phenylisoquinolin-1-amine (33c)}

\section{ond}
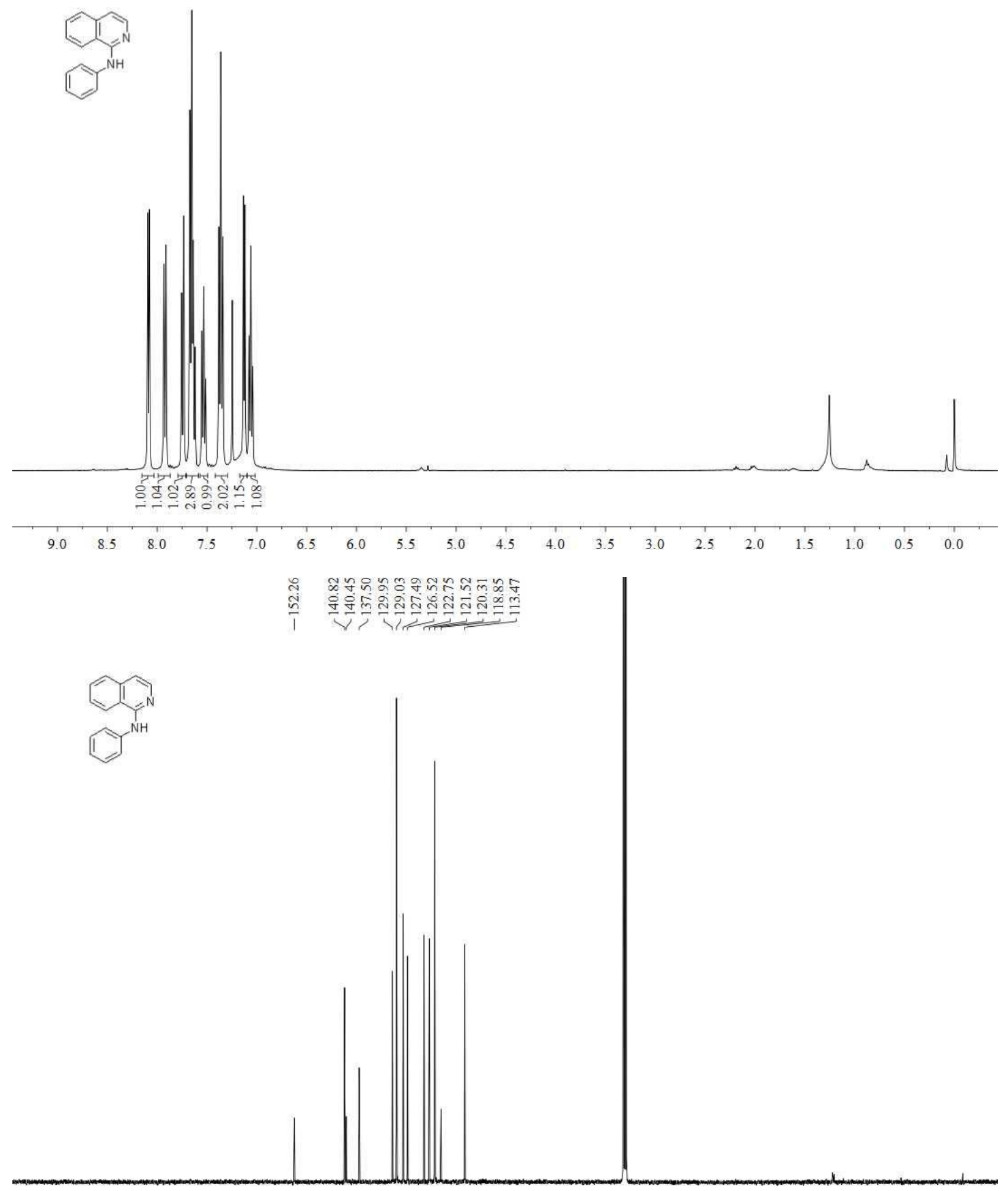

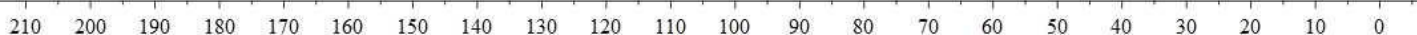




\section{$N$-(4-chlorophenyl)isoquinolin-1-amine (34c)}

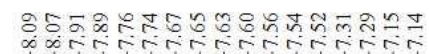
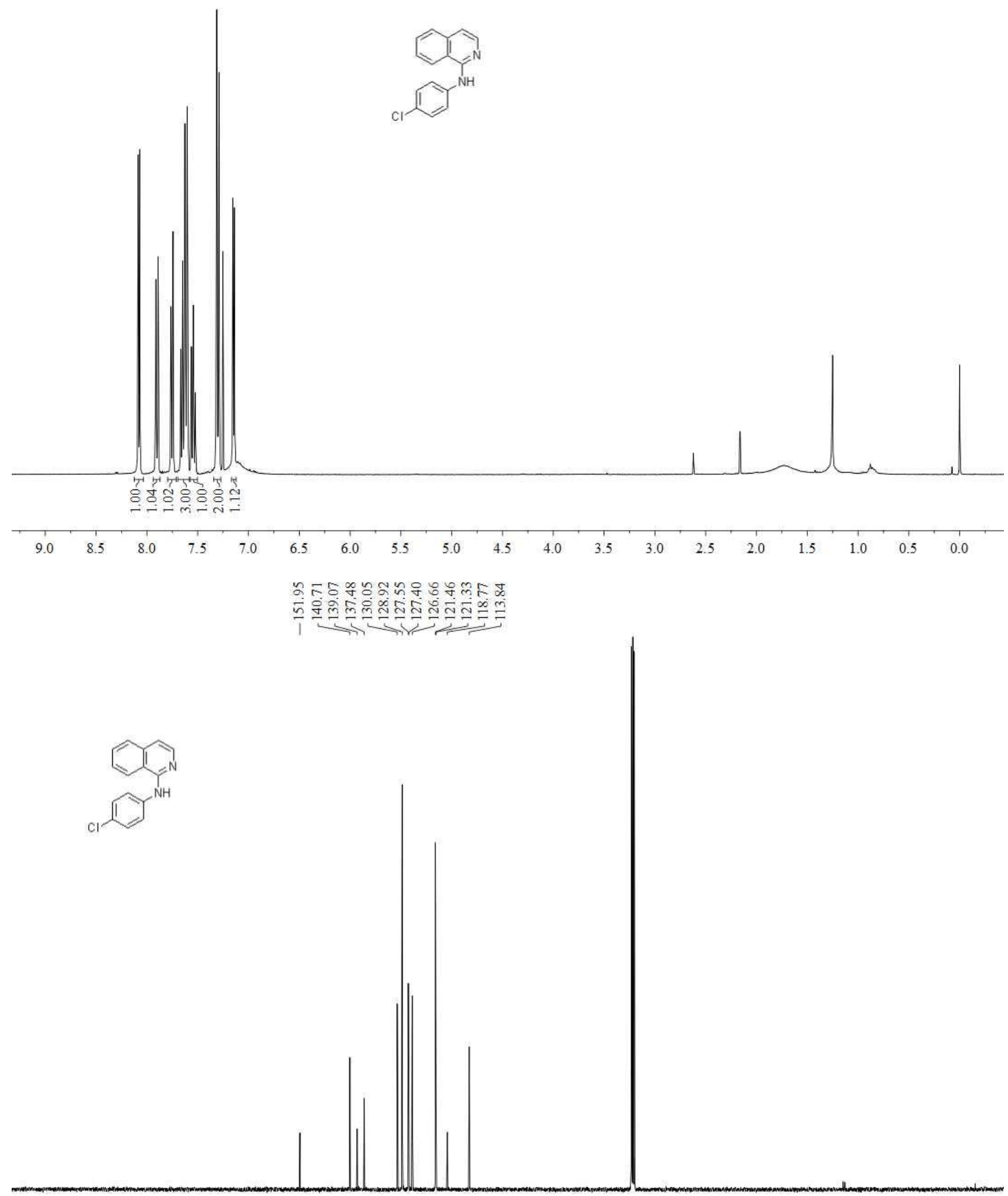

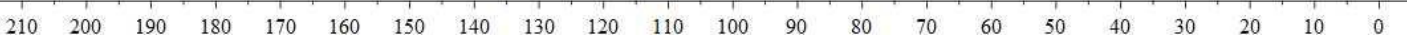




\section{$N$-(4-bromophenyl)isoquinolin-1-amine (35c)}

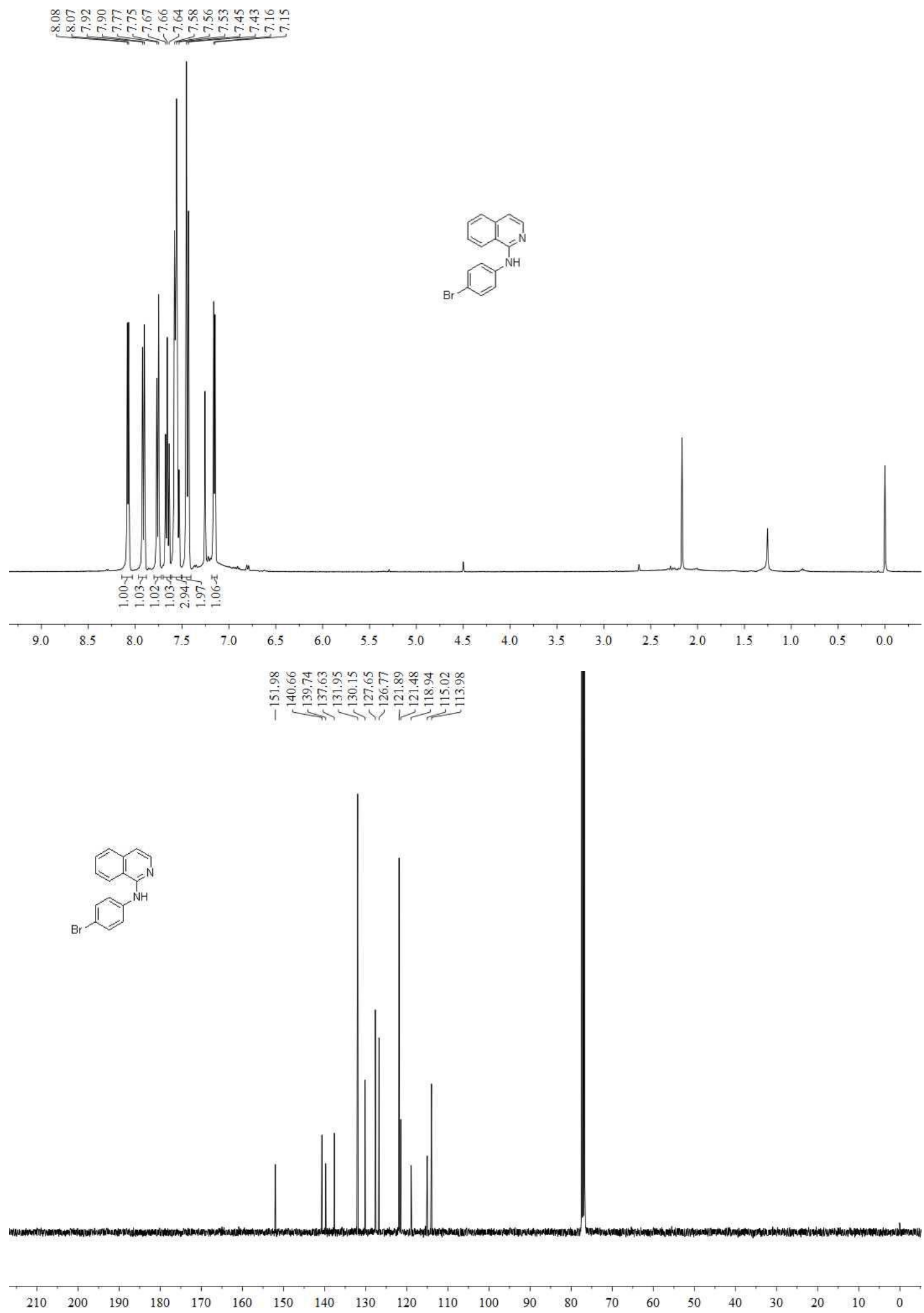


$N$-(p-tolyl)isoquinolin-1-amine (36c)

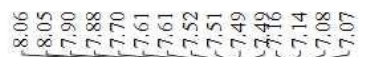
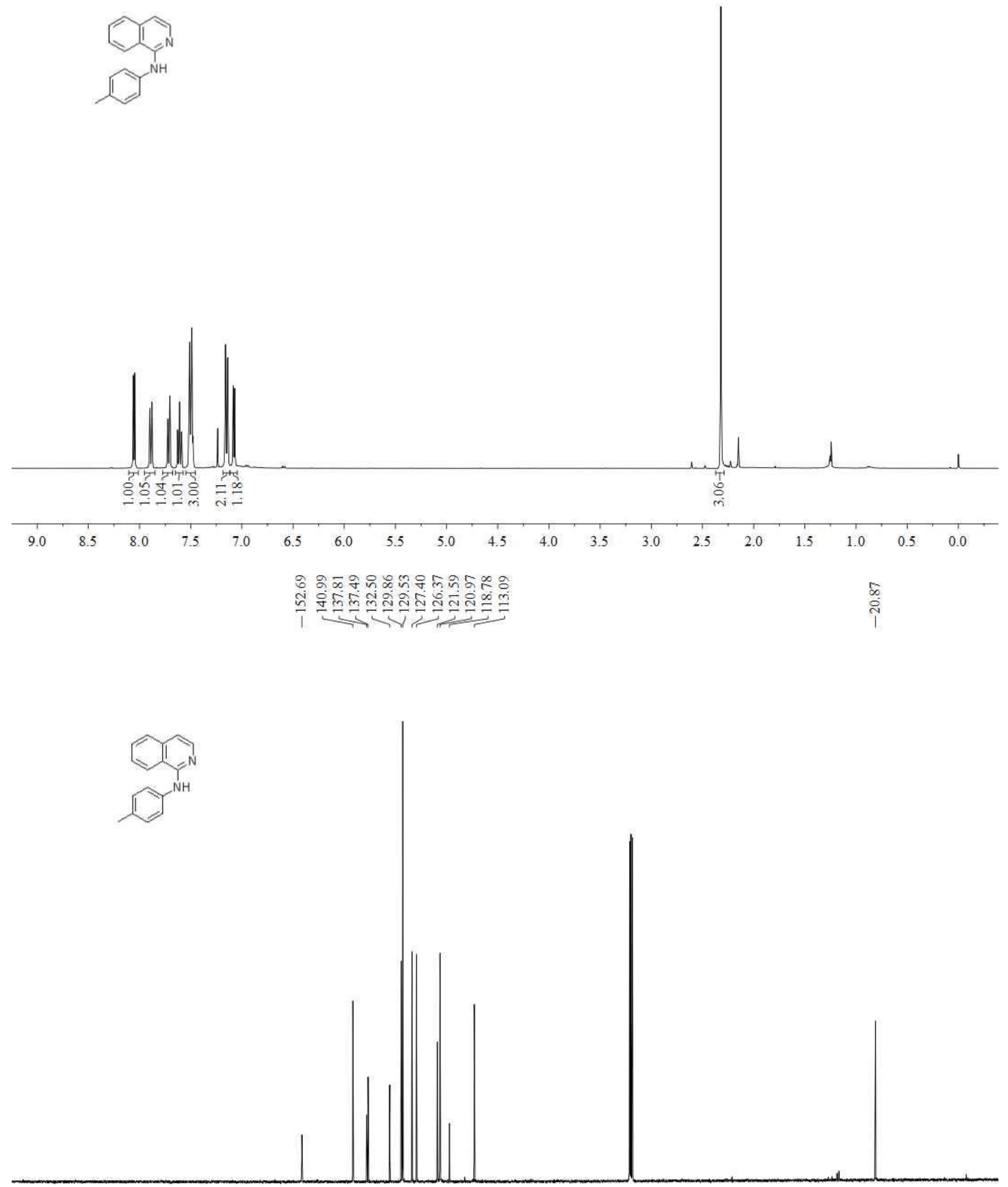

$\begin{array}{llllllllllll}210 & 200 & 190 & 180 & 170 & 160 & 150 & 140 & 130 & 120 & 110 & 100\end{array}$

$90 \quad 80 \quad 70 \quad 60$

$50 \quad 40$

$30 \quad 20 \quad 10 \quad 0$ 


\section{$N$-(4-methoxyphenyl)isoquinolin-1-amine (37c)}
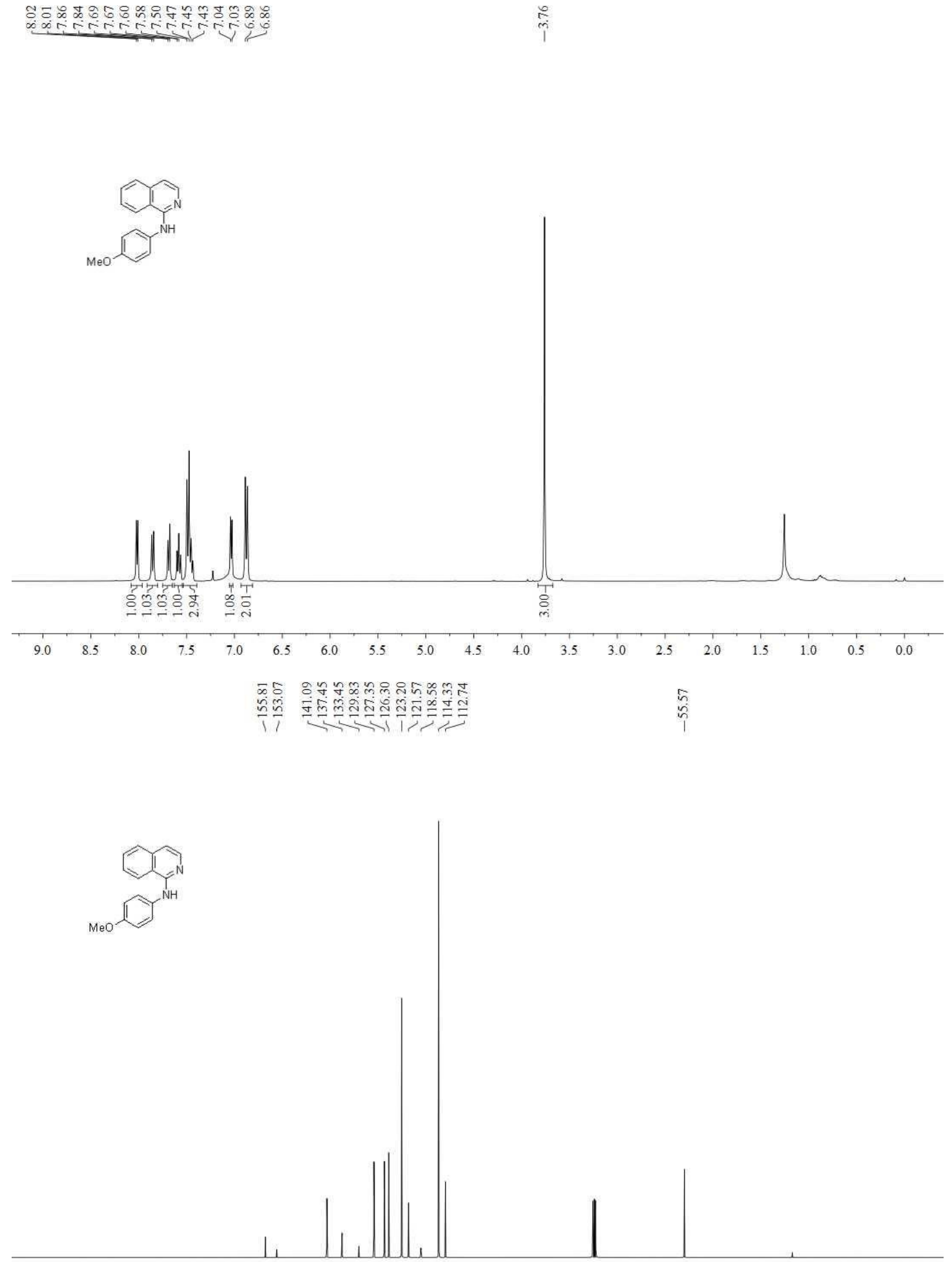


\section{$N$-(3-methoxyphenyl)isoquinolin-1-amine (38c)}

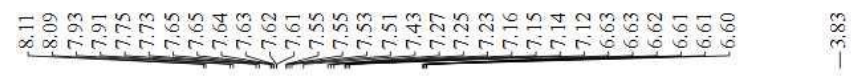

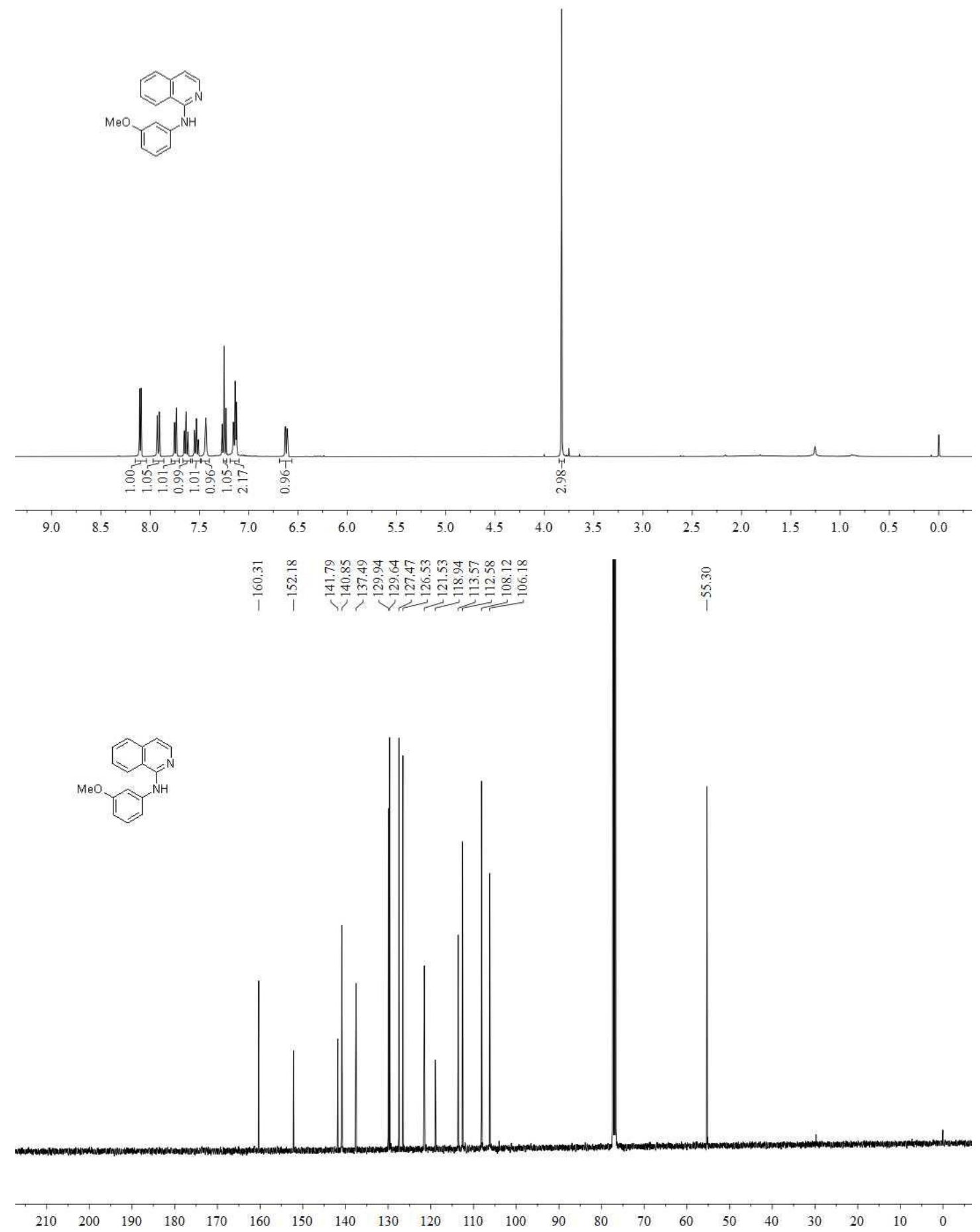




\section{$N$-(2-methoxyphenyl)isoquinolin-1-amine (39c)}

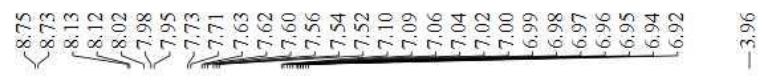
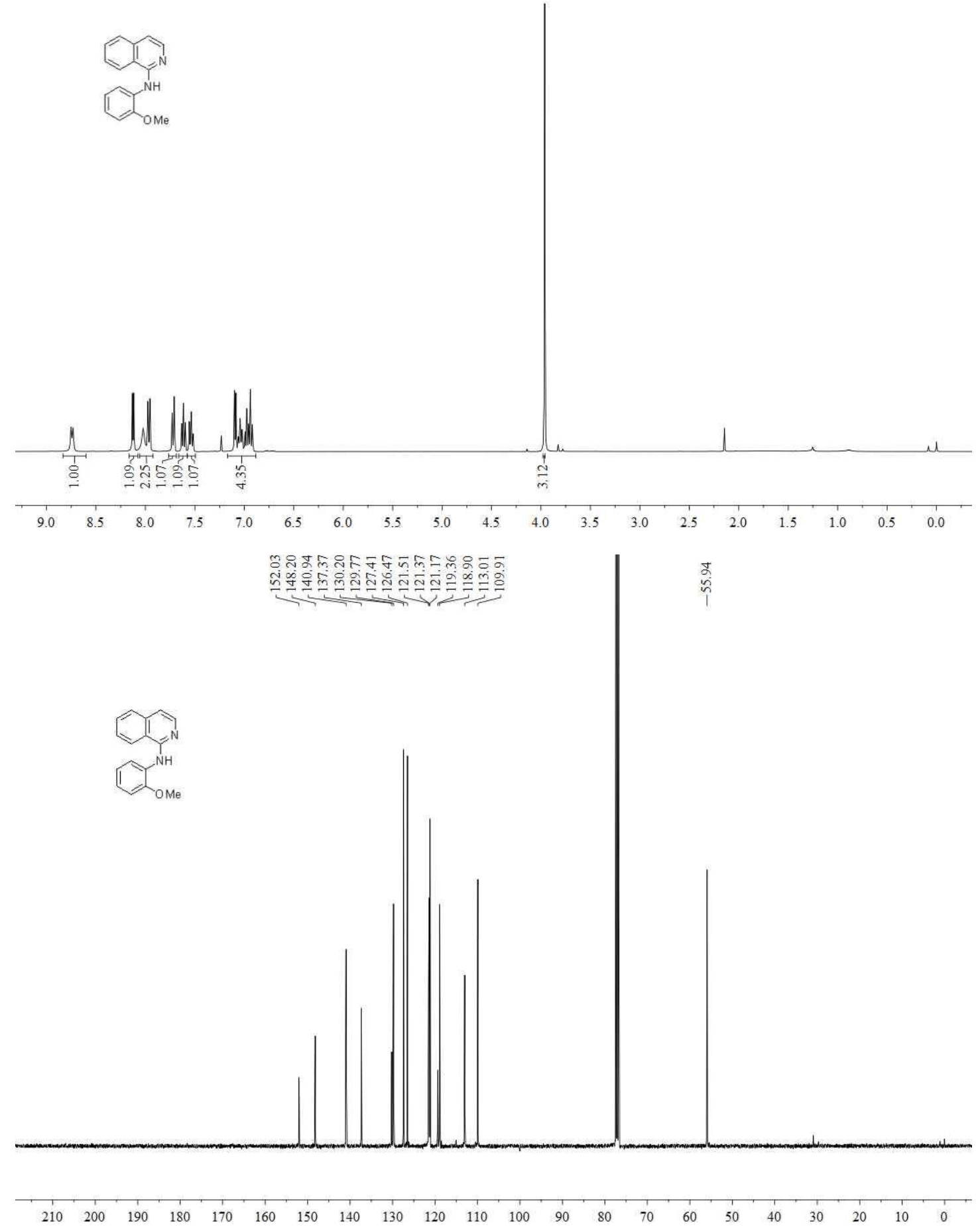
$N$-(3,5-dimethylphenyl)isoquinolin-1-amine (40c)

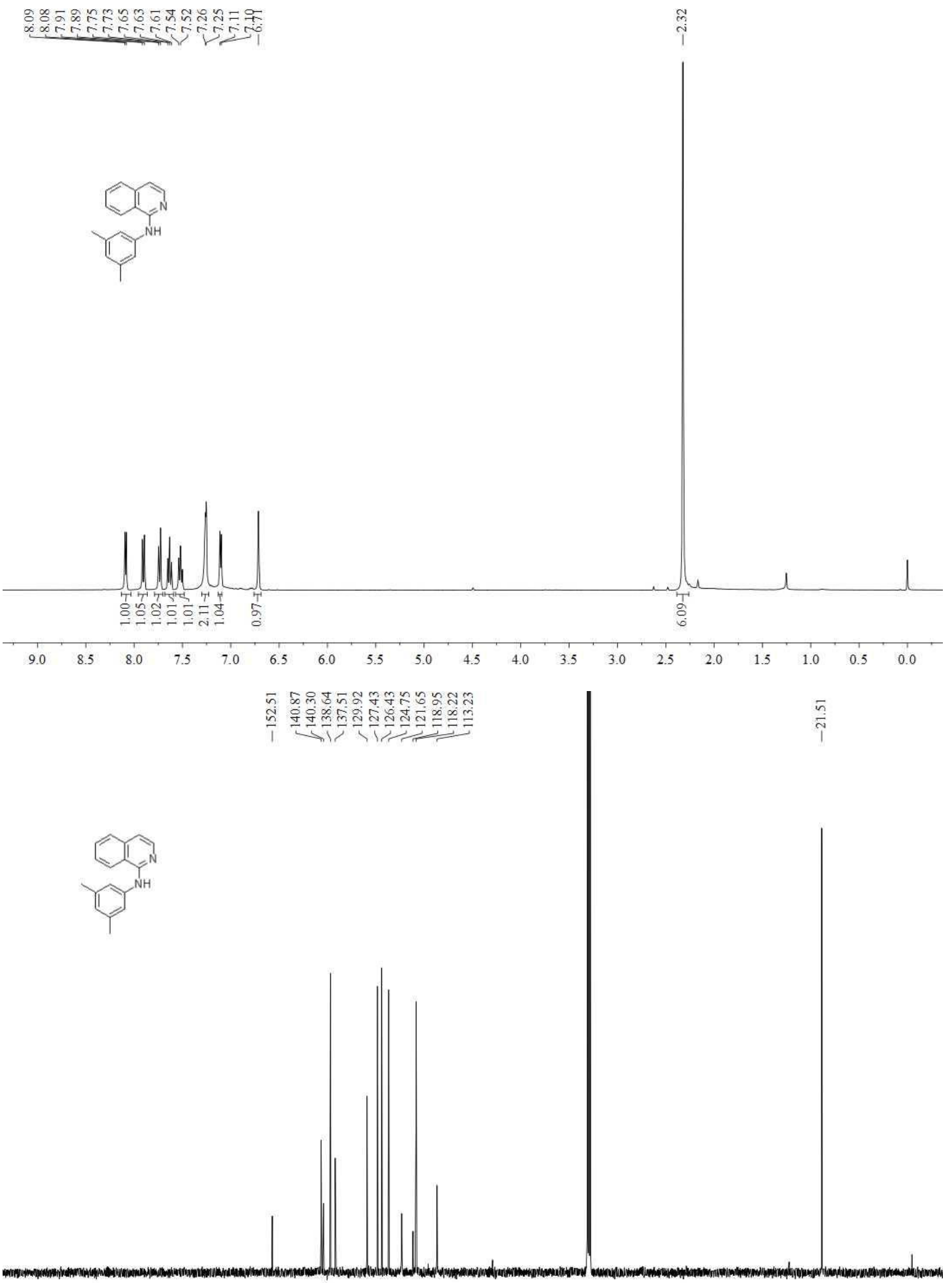

(1.0)

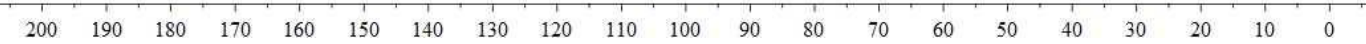




\section{$N$-(dibenzo[b,d]furan-3-yl)isoquinolin-1-amine (41c)}

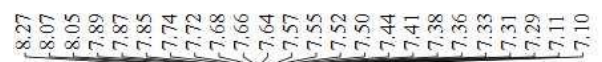

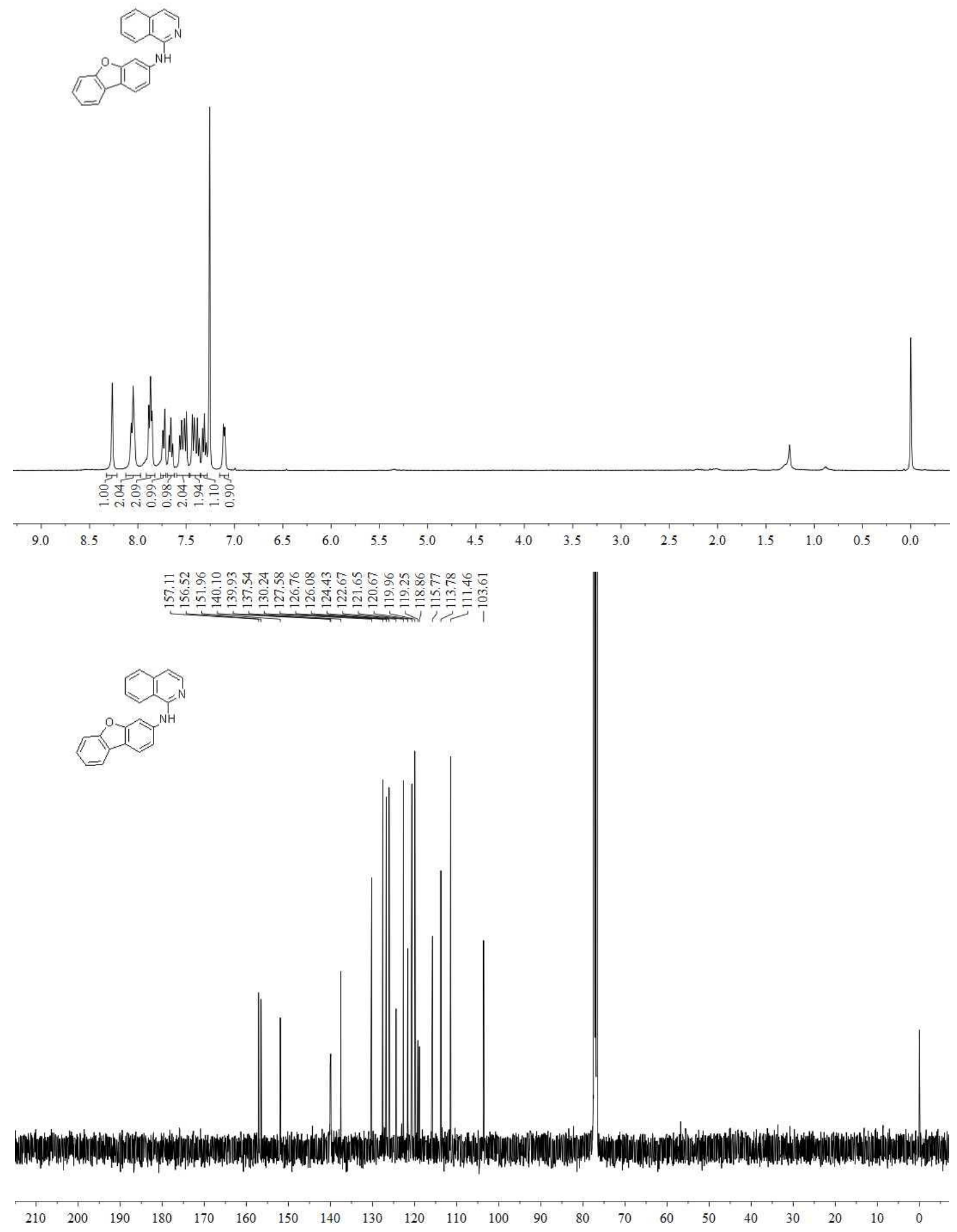


$\mathrm{N}, \mathrm{N}$-diethylisoquinolin-1-amine (42c)

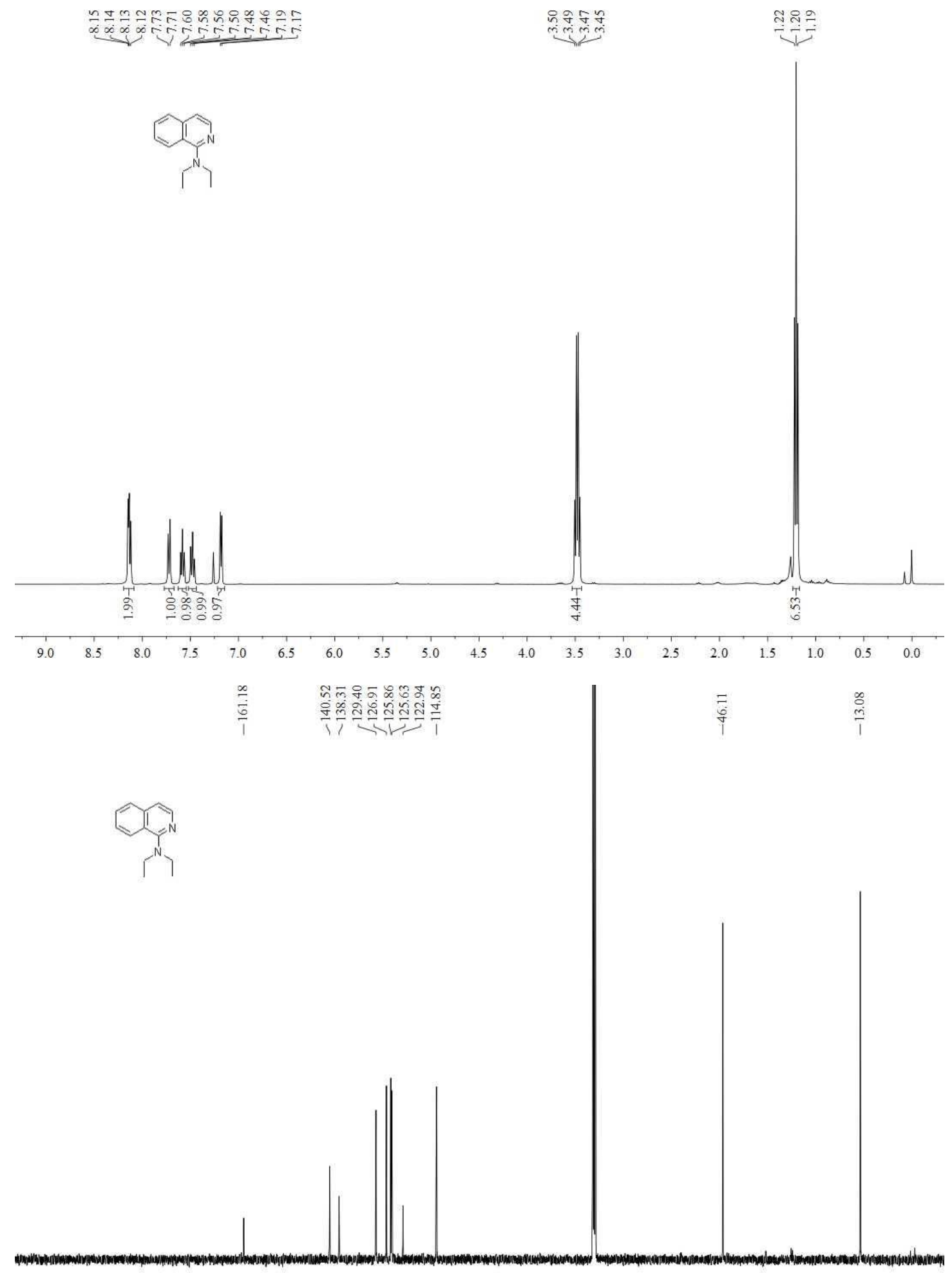

1.0.5 


\section{$N$-benzyl- $N$-methylisoquinolin-1-amine (43c)}

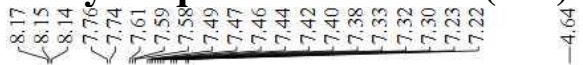
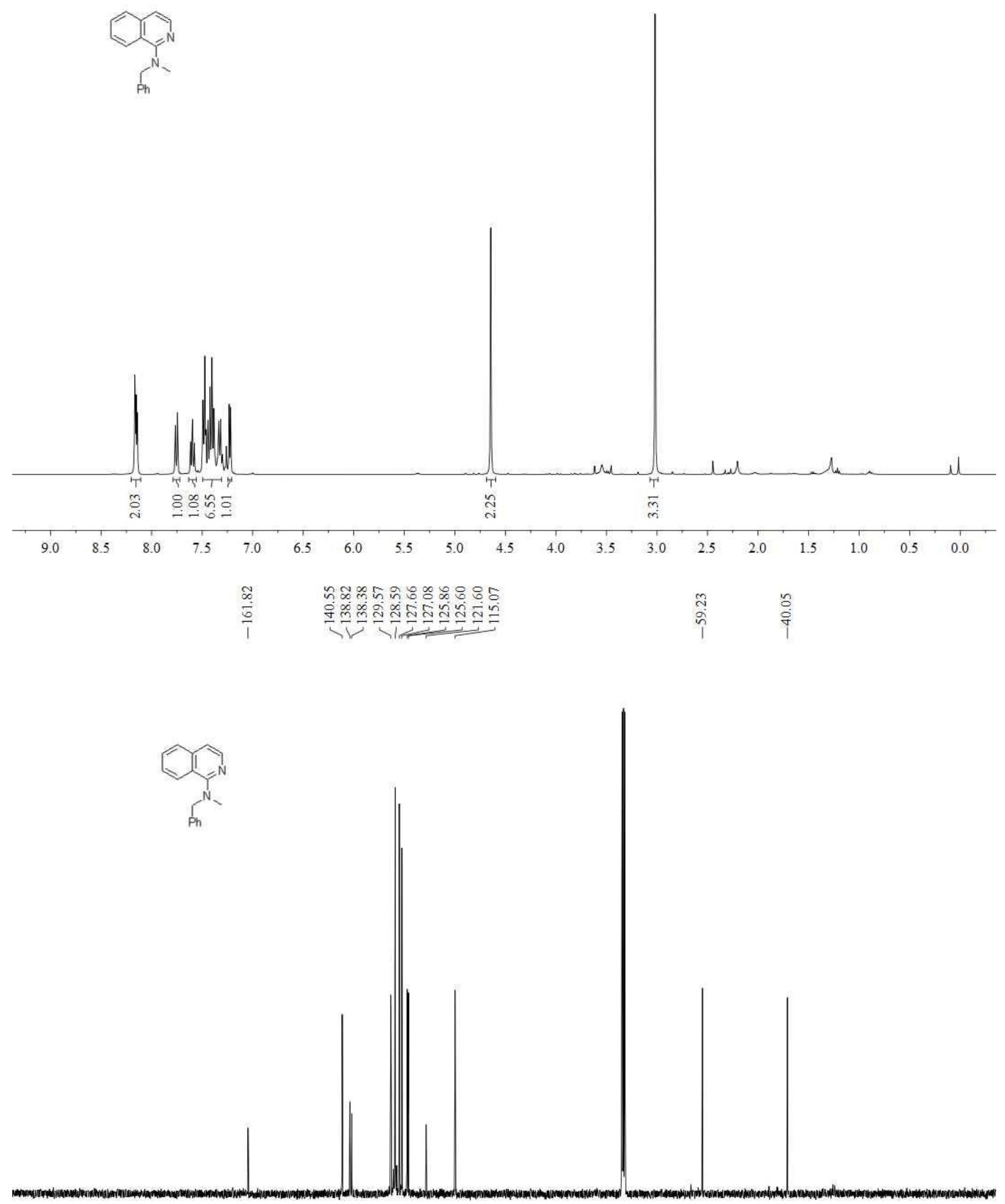

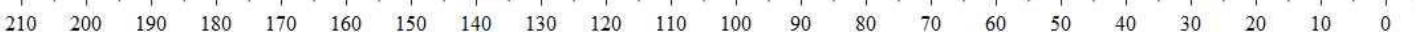


1-(azetidin-1-yl)isoquinoline (44c)

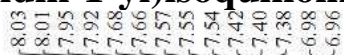

$\sum_{\substack{N \\ i}}^{N}$

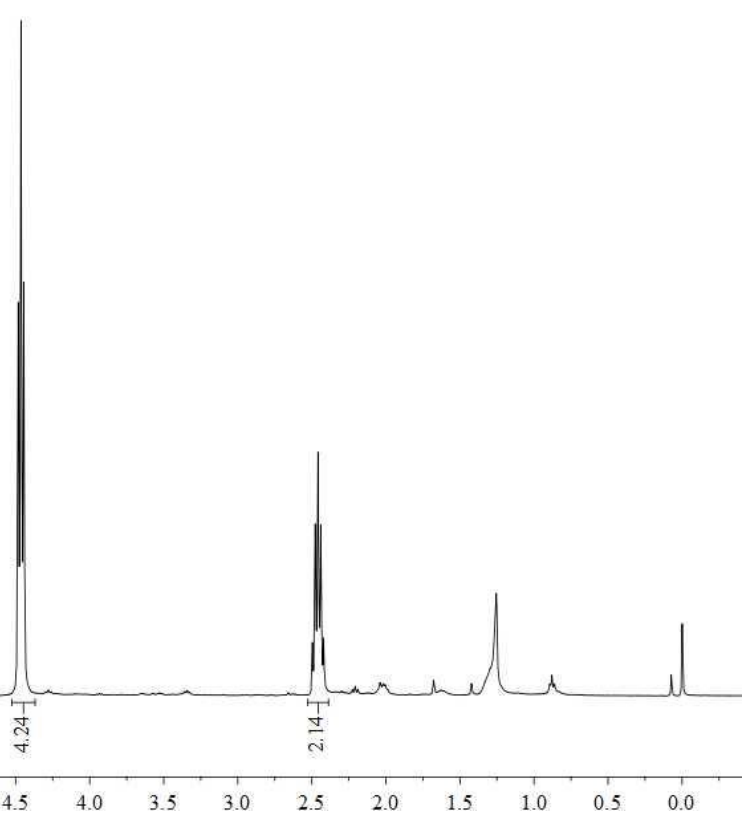

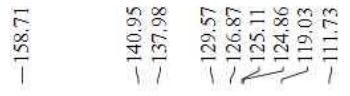
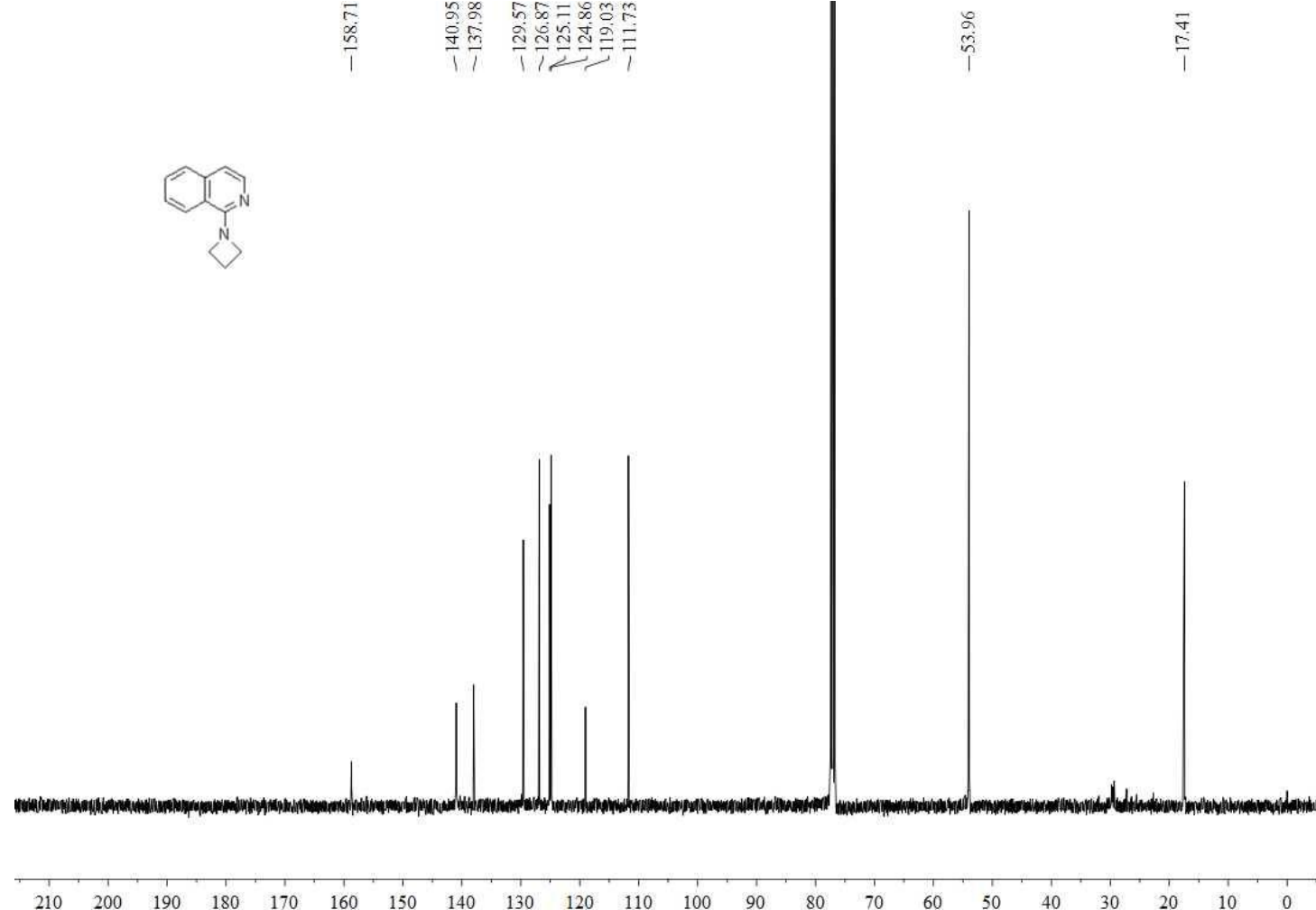


\section{1-(pyrrolidin-1-yl)isoquinoline (45c)}
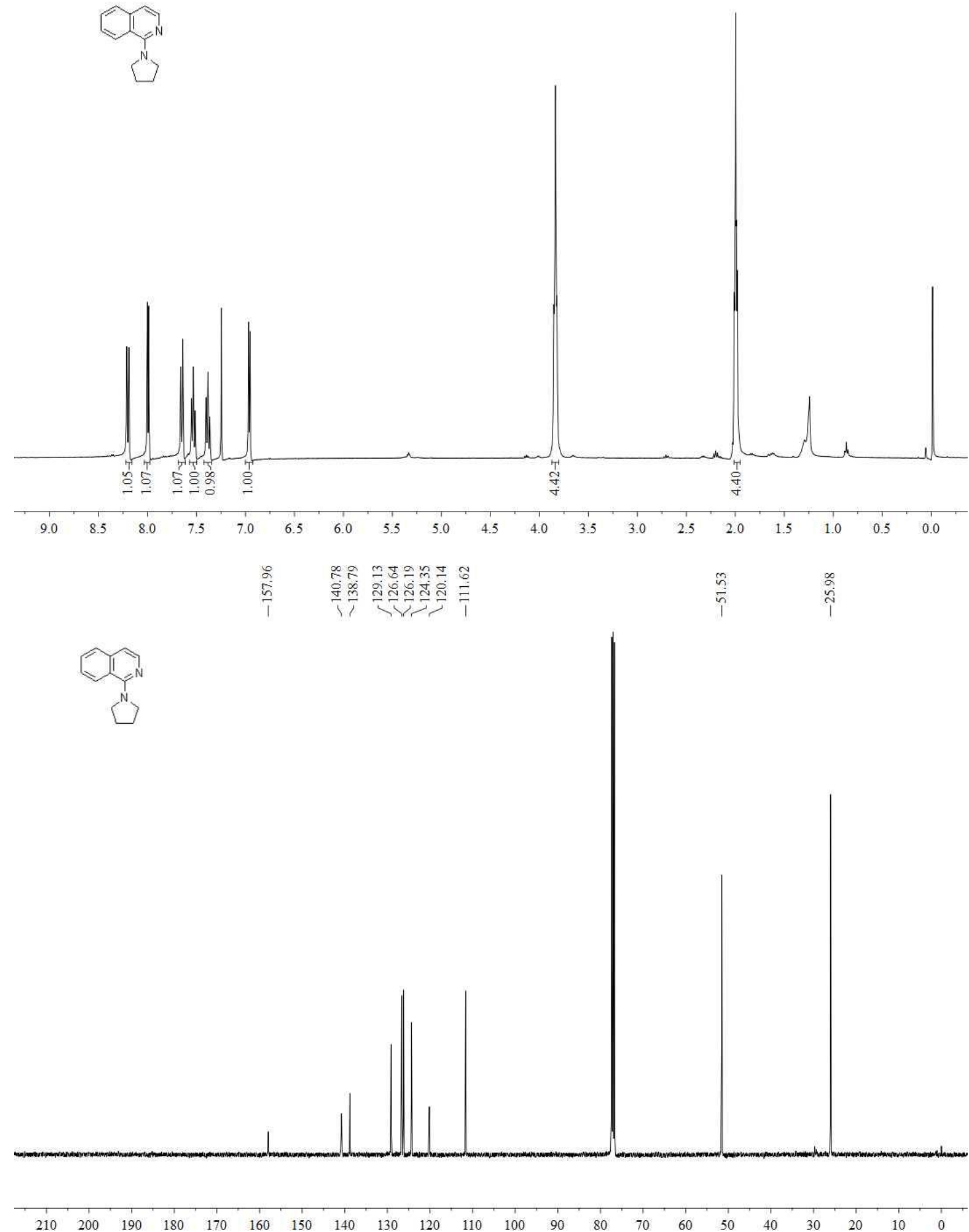


\section{4-(isoquinolin-1-yl)morpholine (46c)}

주에
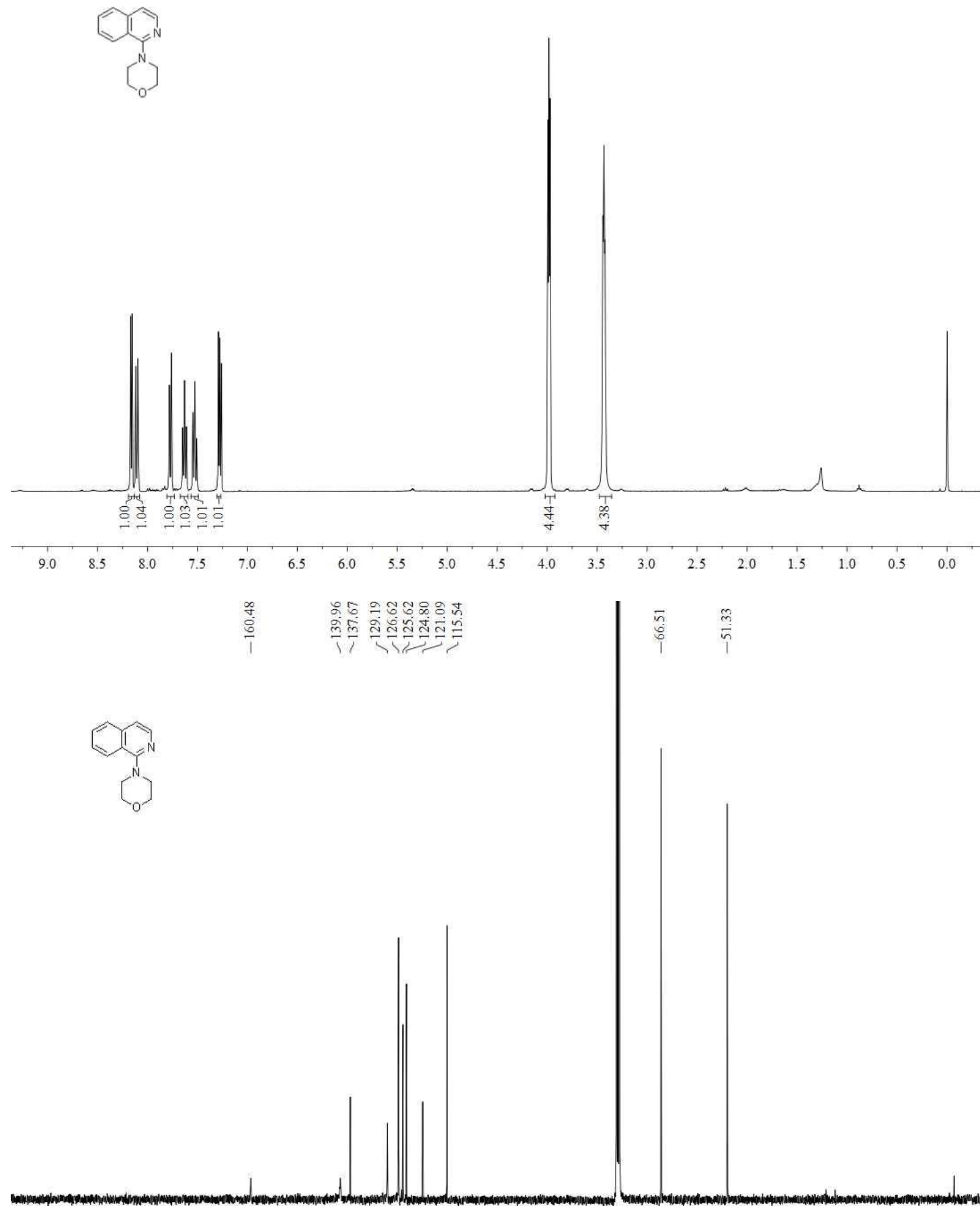

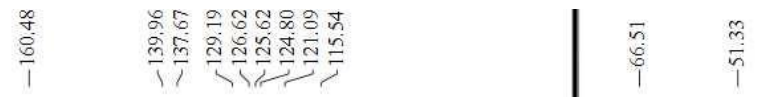

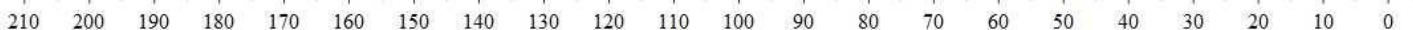




\section{1-(4-methylpiperidin-1-yl)isoquinoline (47c)}

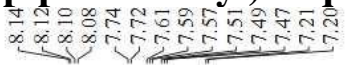
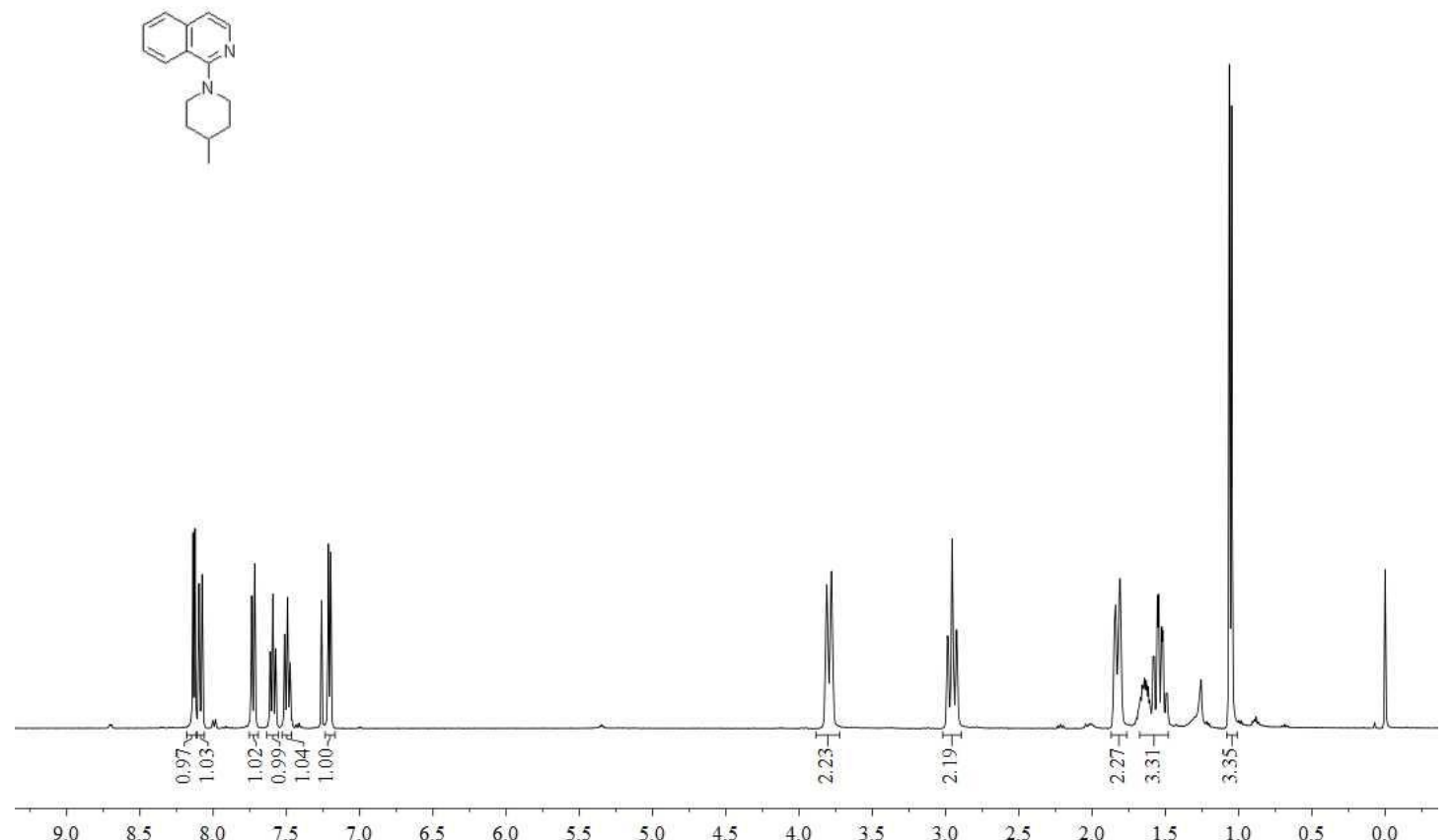

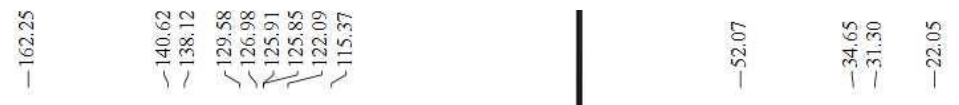
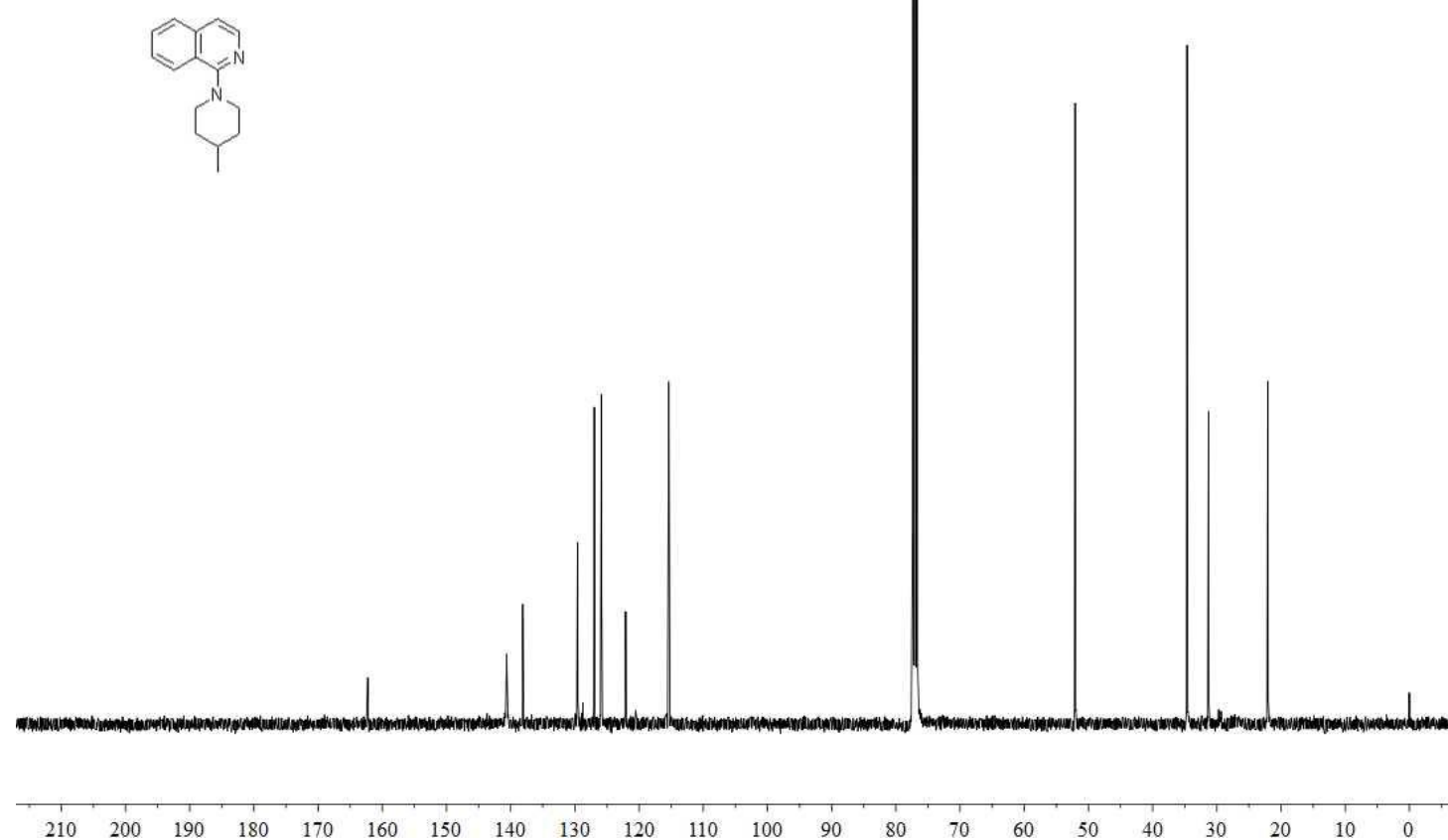
1-(4-phenylpiperidin-1-yl)isoquinoline (48c)

क
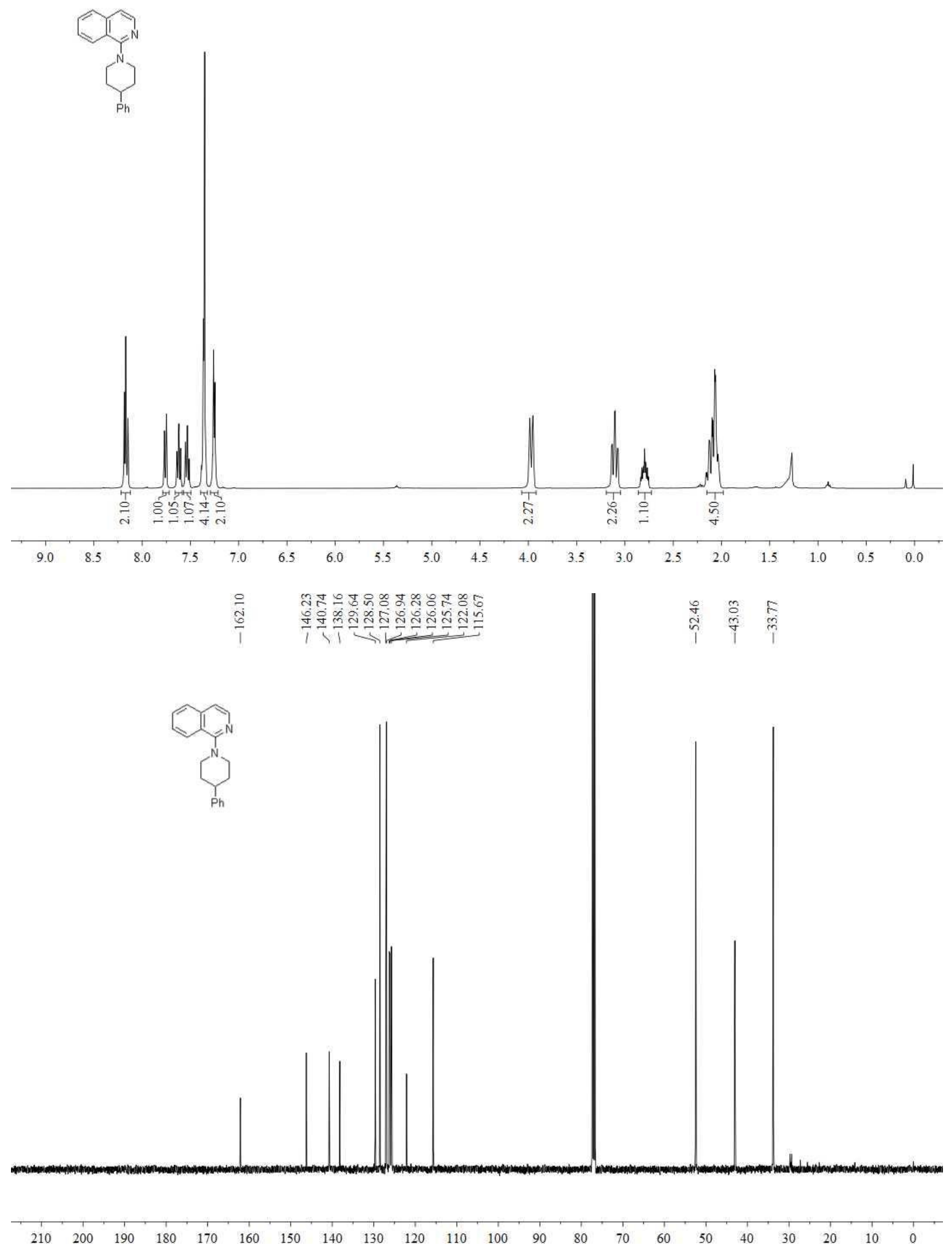
Ethyl 1-(isoquinolin-1-yl)piperidine-4-carboxylate (49c)

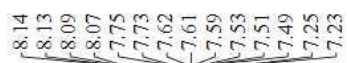

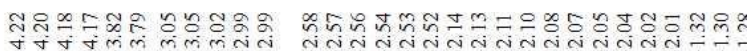

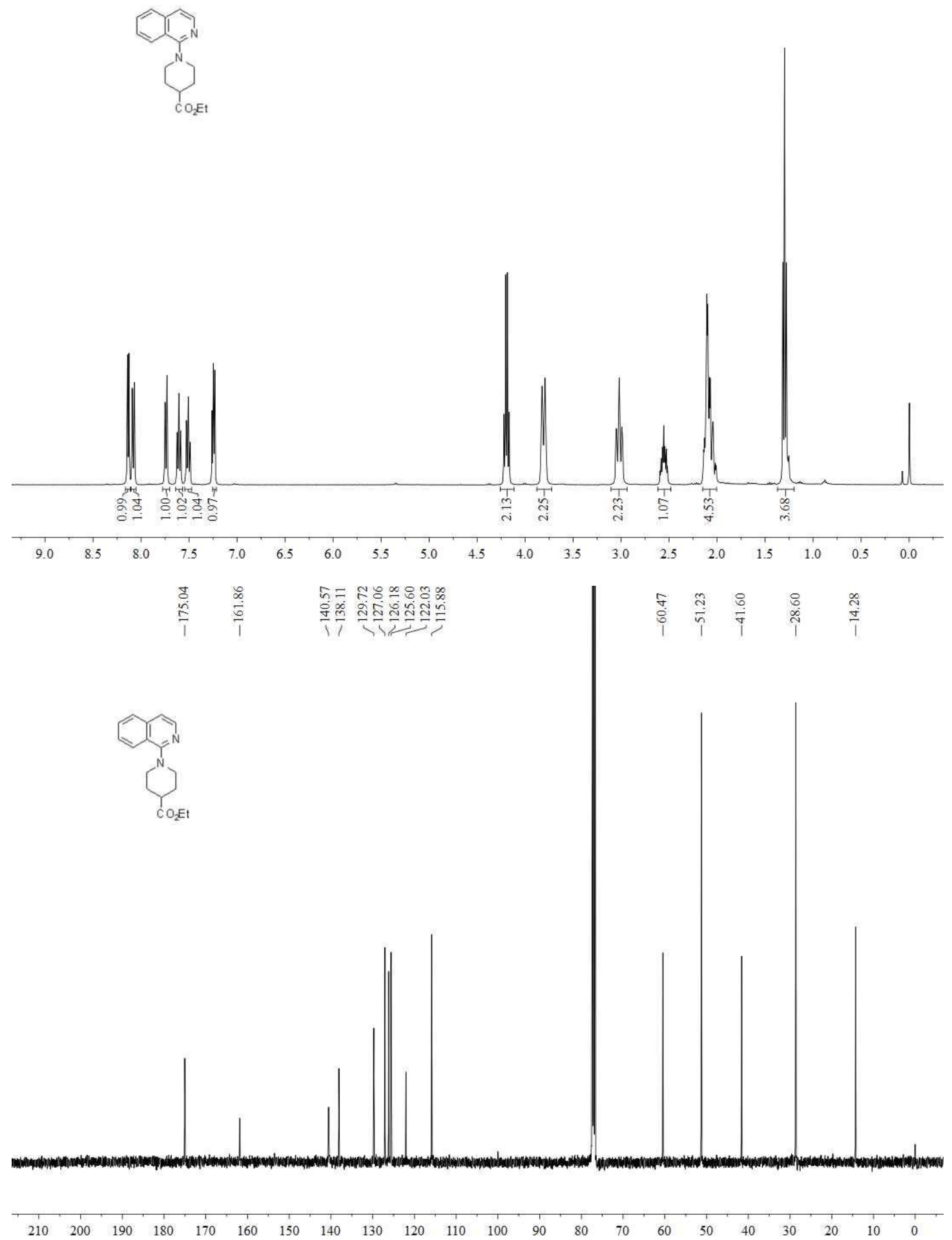

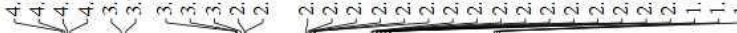




\section{$N^{1}$-(isoquinolin-1-yl)- $N^{1}$-phenylethane-1,2-diamine (50c)}

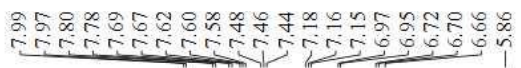

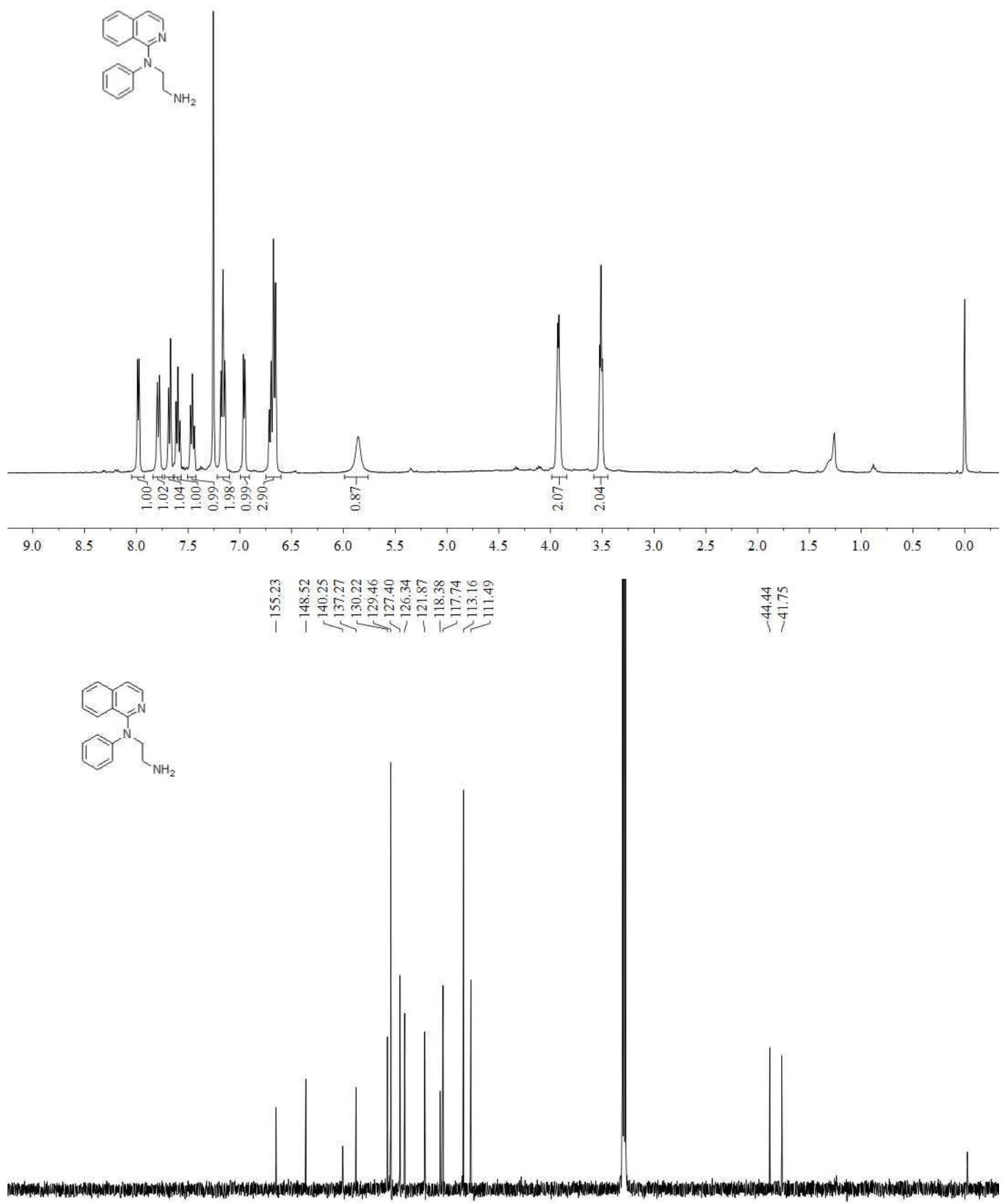

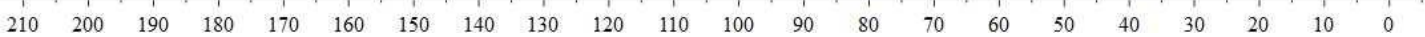




\section{$N$-phenyl- $N$-(piperidin-4-yl)isoquinolin-1-amine (51c)}
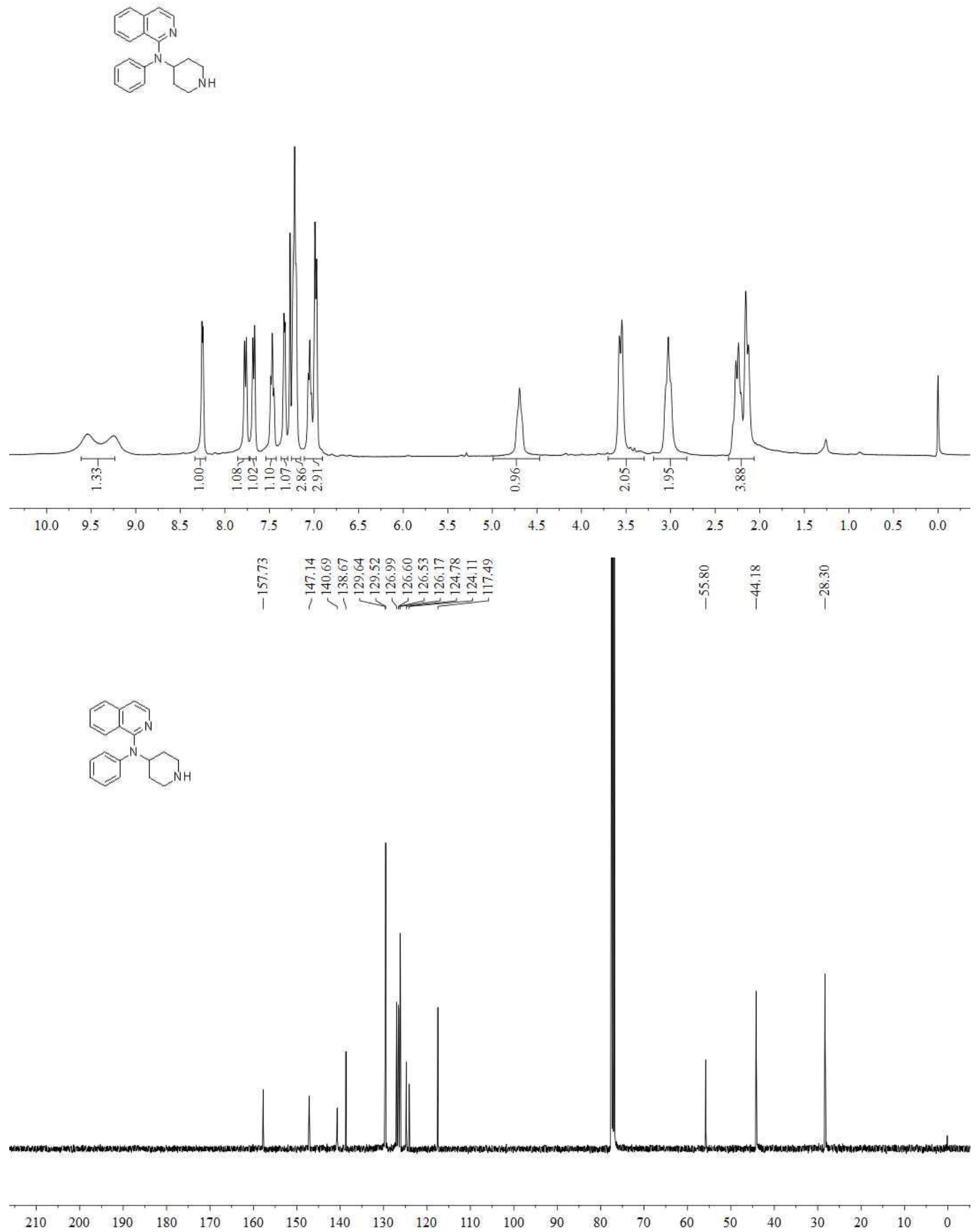


\section{$N$-(4-(2-aminoethyl)phenyl)isoquinolin-1-amine (52c)}

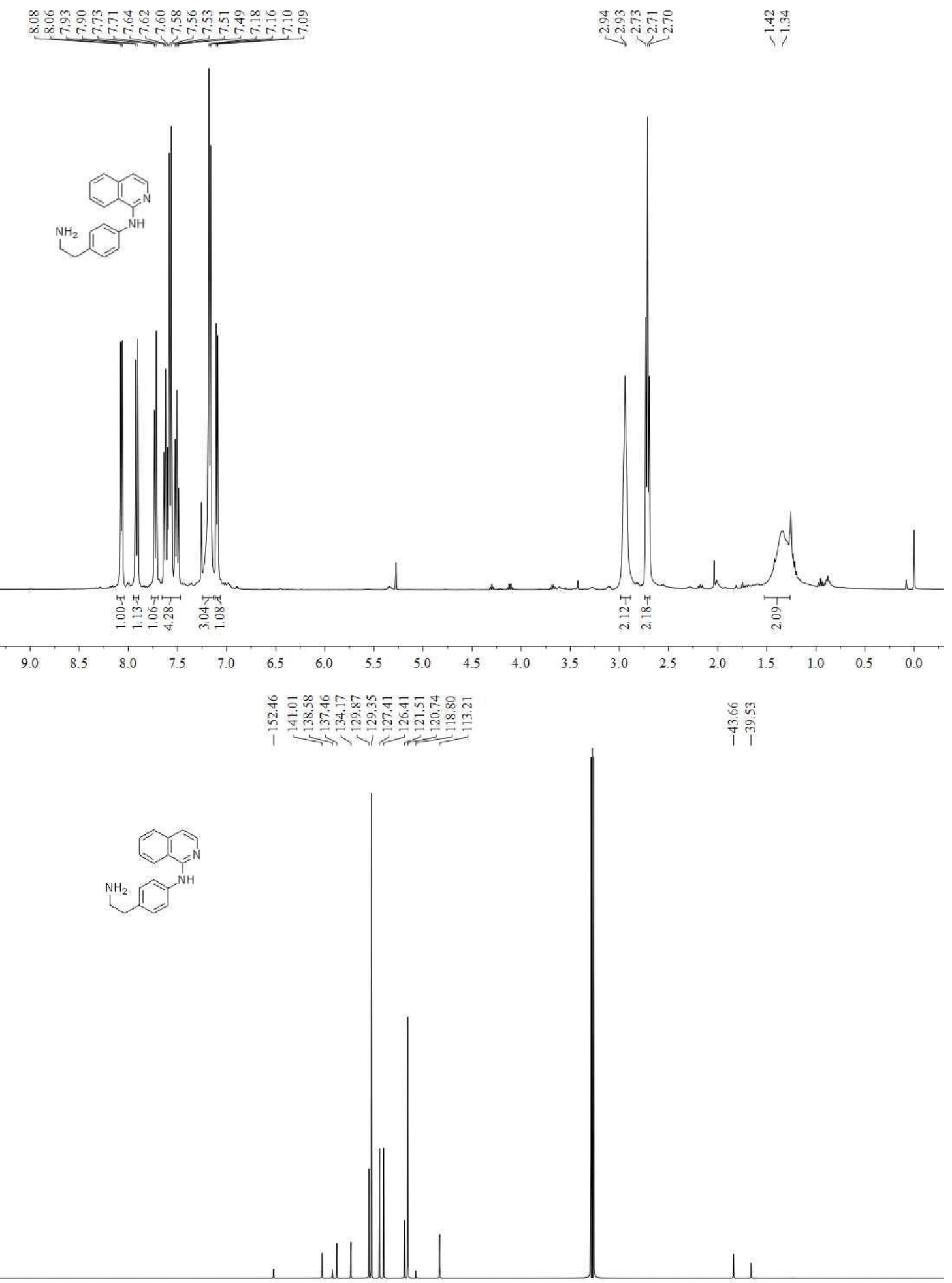

$\begin{array}{llllllllllllllllllllllll}210 & 200 & 190 & 180 & 170 & 160 & 150 & 140 & 130 & 120 & 110 & 100 & 90 & 80 & 70 & 60 & 50 & 40 & 30 & 20 & 10 & 0\end{array}$ 


\section{$N^{1}$-(isoquinolin-1-yl)benzene-1,4-diamine (53c)}

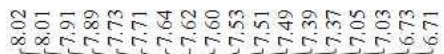

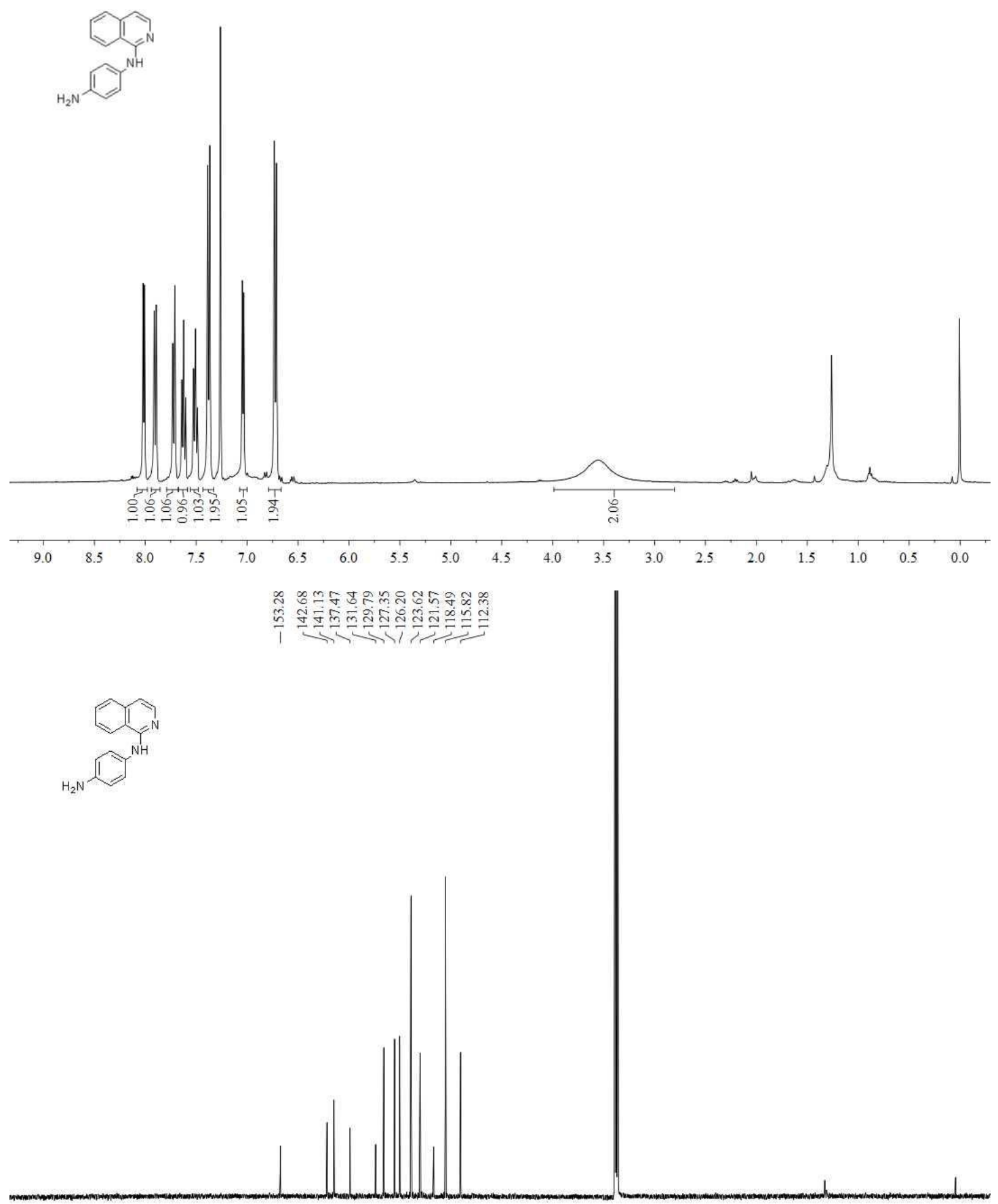

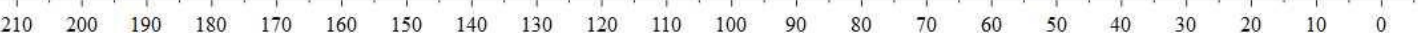




\section{$N$-(4-(morpholinomethyl)phenyl)isoquinolin-1-amine (54c)}

o.

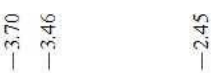
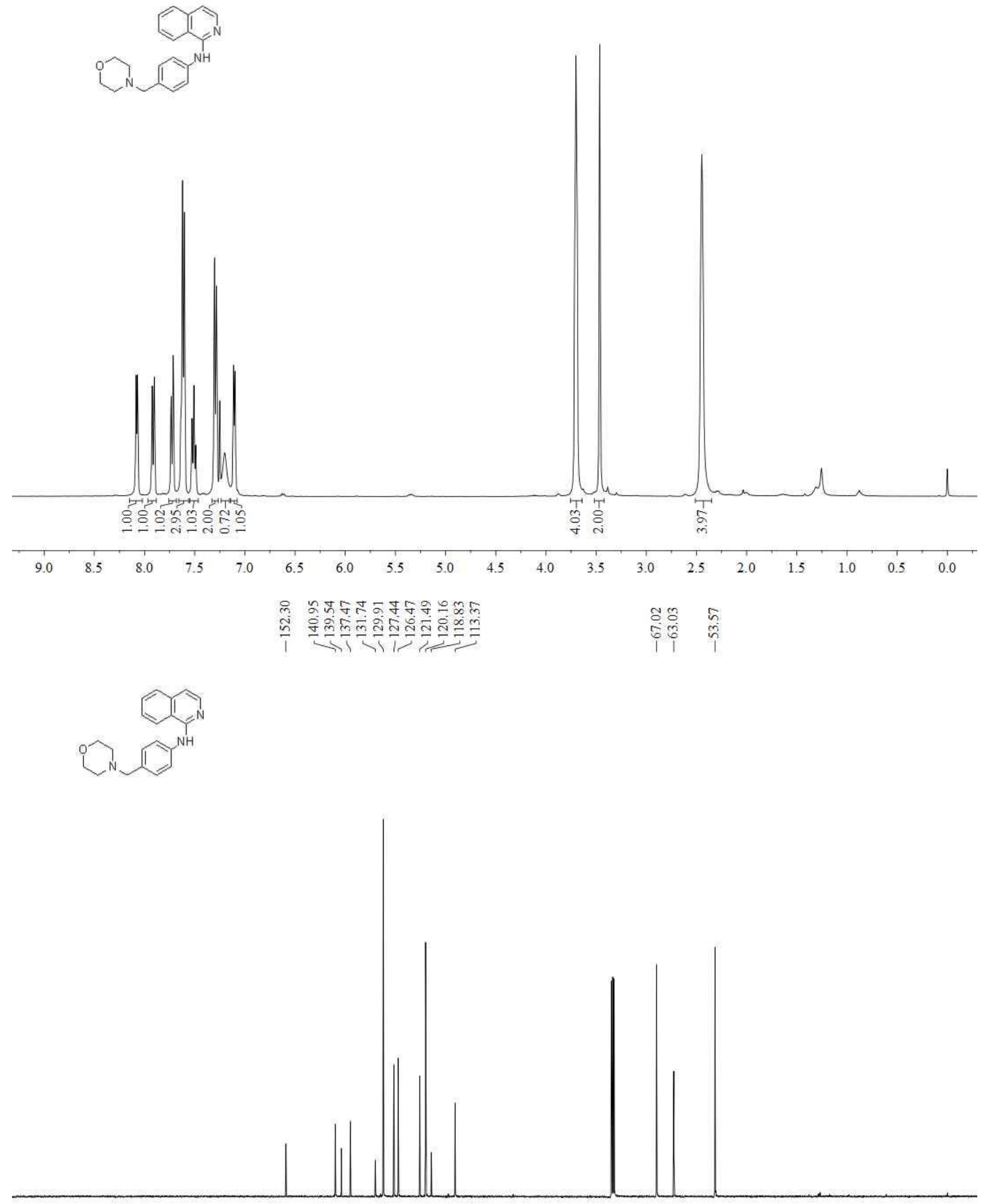

$\begin{array}{llllllllllllllllllllll}210 & 200 & 190 & 180 & 170 & 160 & 150 & 140 & 130 & 120 & 110 & 100 & 90 & 80 & 70 & 60 & 50 & 40 & 30 & 20 & 10 & 0\end{array}$ 
1-(isoquinolin-1-yl)piperidin-4-amine (55c)

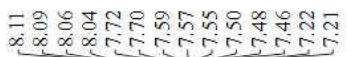

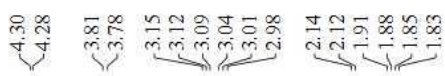

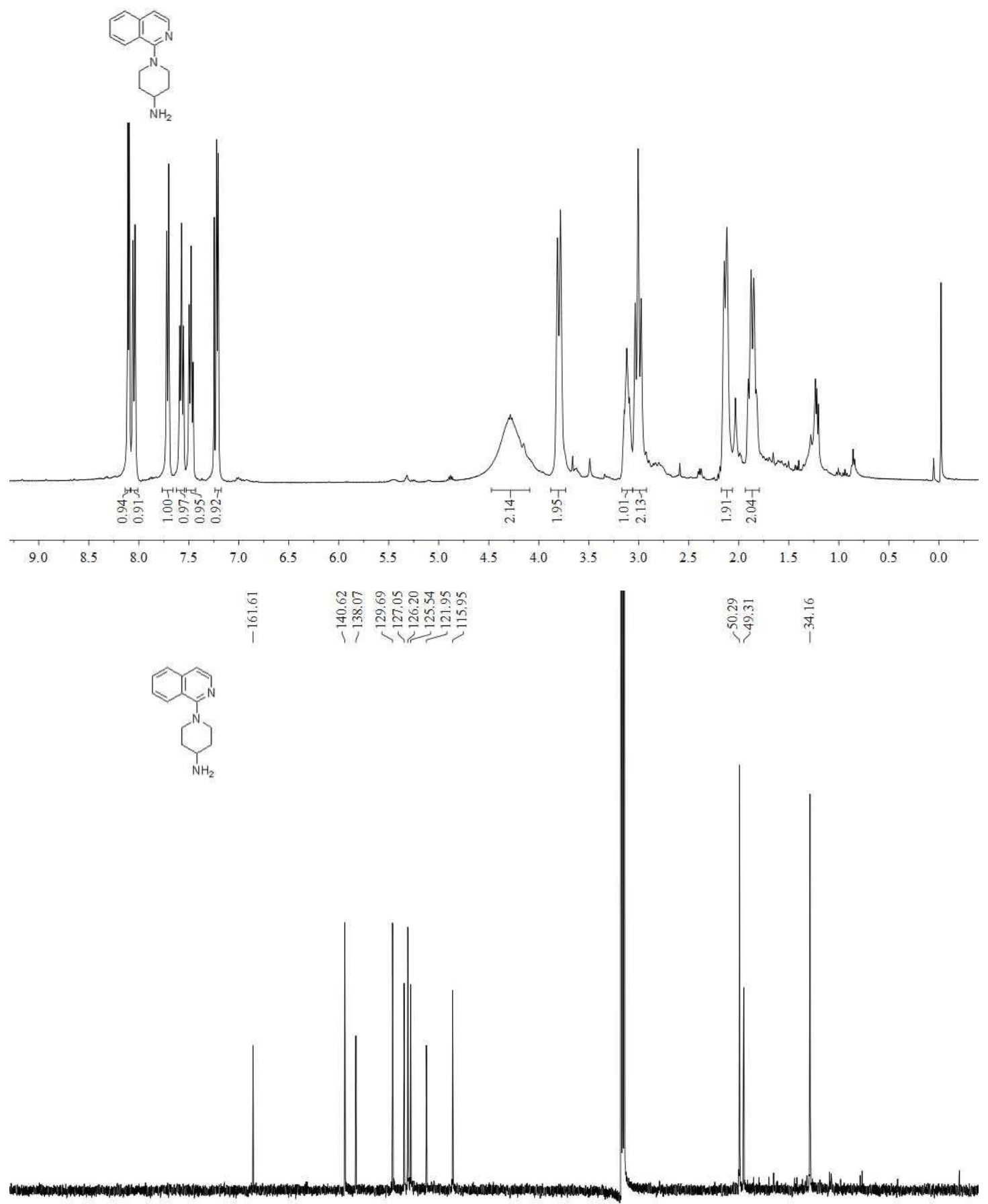

$100 \quad 9$

$80 \quad 70$

$60 \quad 50$

30

$10 \quad 0$ 
2-(4-(isoquinolin-1-ylamino)phenyl)acetamide (56c)

m̄m

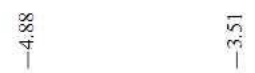

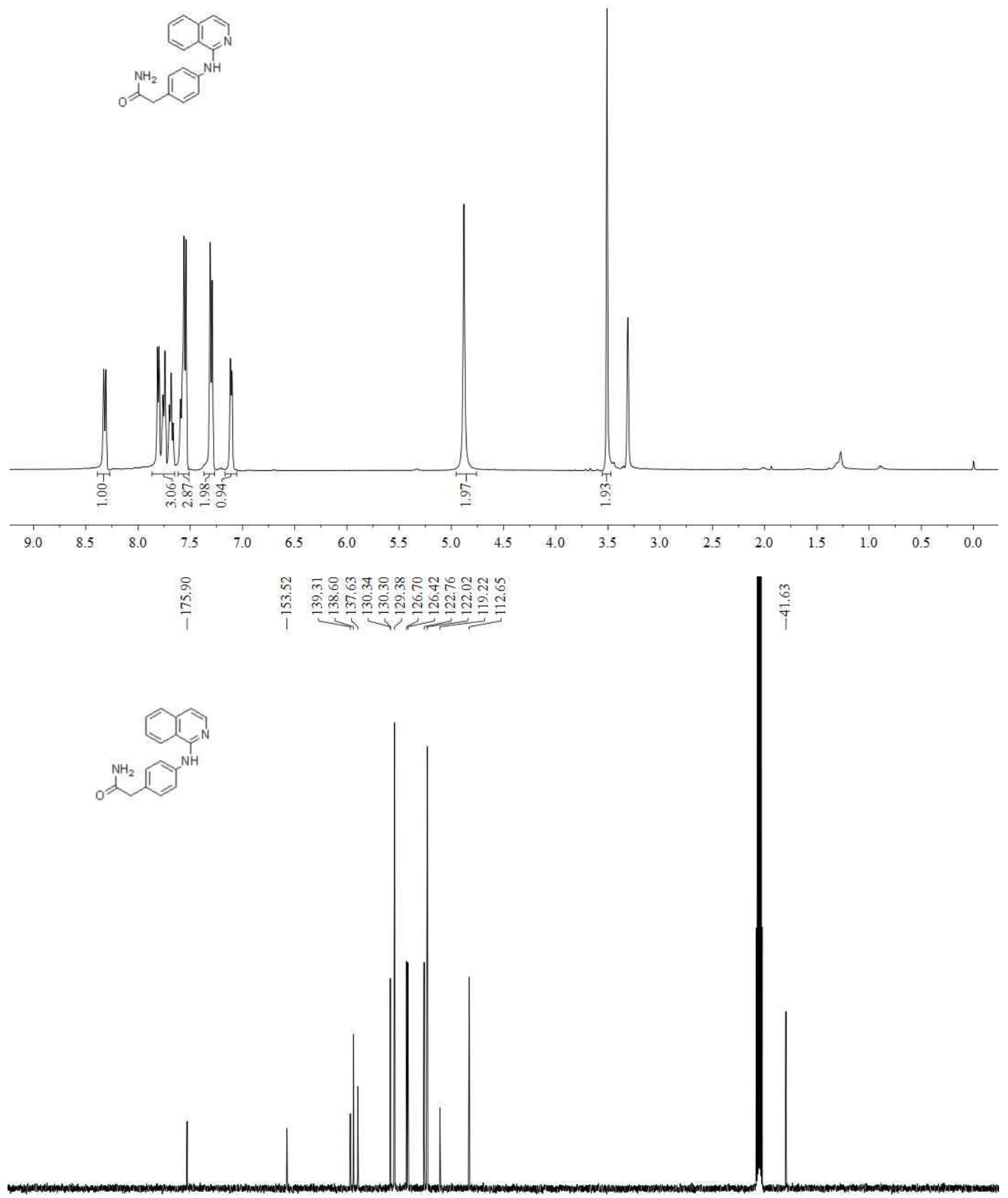

$\begin{array}{lllllllllllllllllllllllllll}210 & 200 & 190 & 180 & 170 & 160 & 150 & 140 & 130 & 120 & 110 & 100 & 90 & 80 & 70 & 60 & 50 & 40 & 30 & 20 & 10 & 0\end{array}$ 
5-(isoquinolin-1-yl)-4,5-dihydro-1H-benzo[b][1,4]diazepin-2(3H)-one (57c)

m

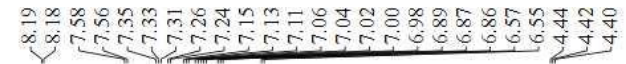

욛ำ

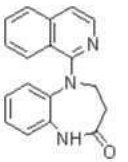

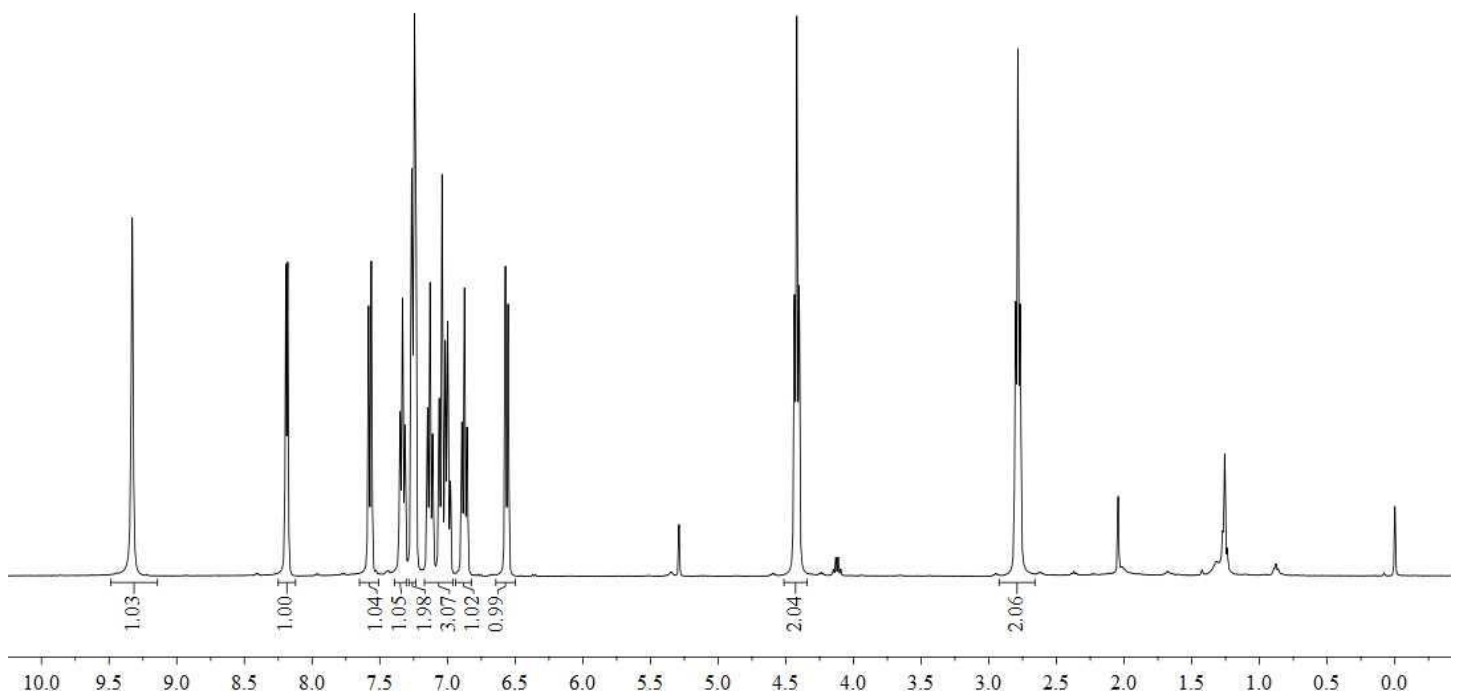

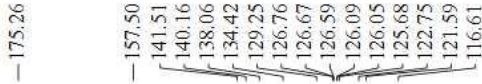

$\stackrel{i}{m} \quad \tilde{n}$
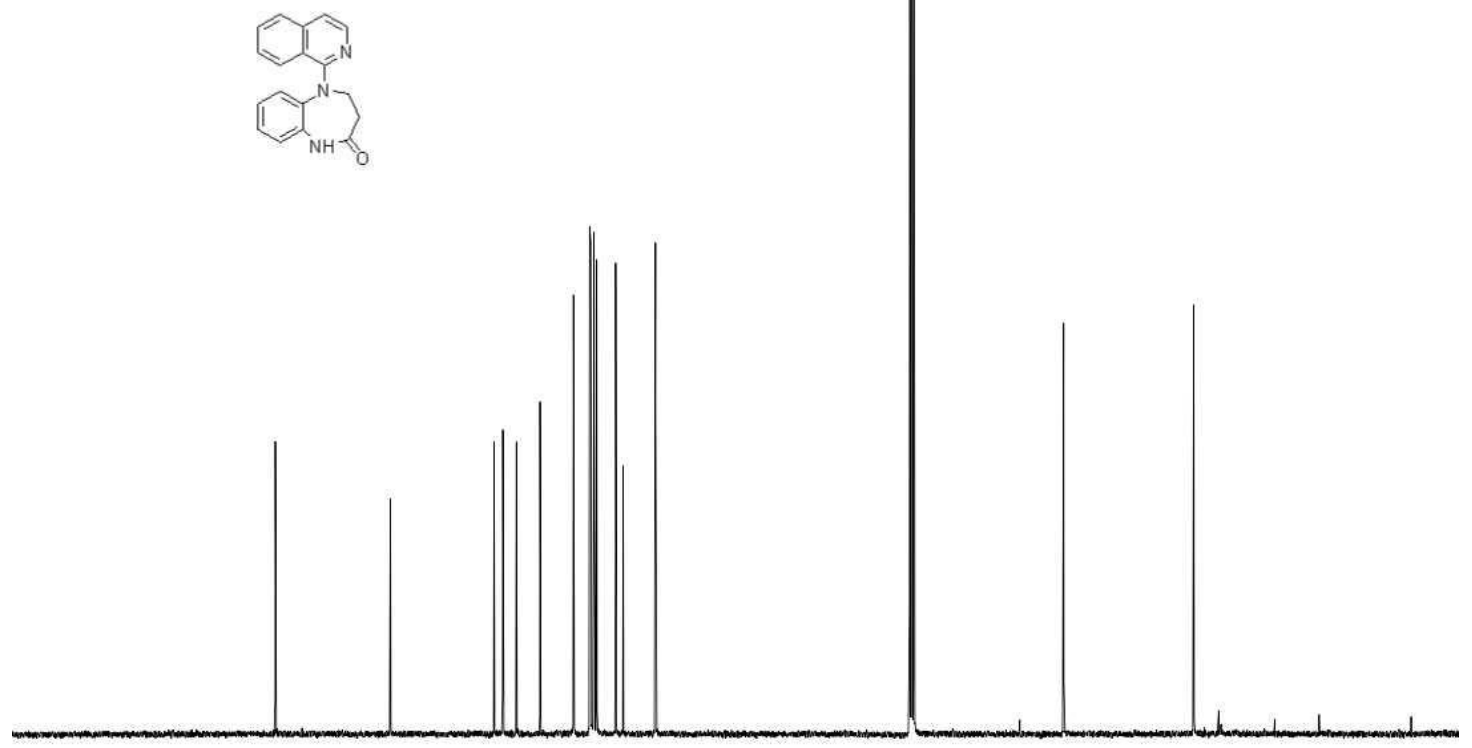

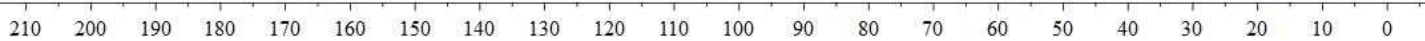


(S)-ethyl 2-((tert-butoxycarbonyl)amino)-3-(4-(isoquinolin-1-ylamino)phenyl)propanoate (58c)

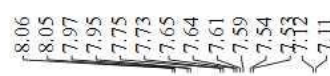

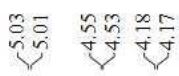

$\stackrel{8}{\stackrel{\leftrightarrow}{i}}$

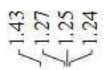
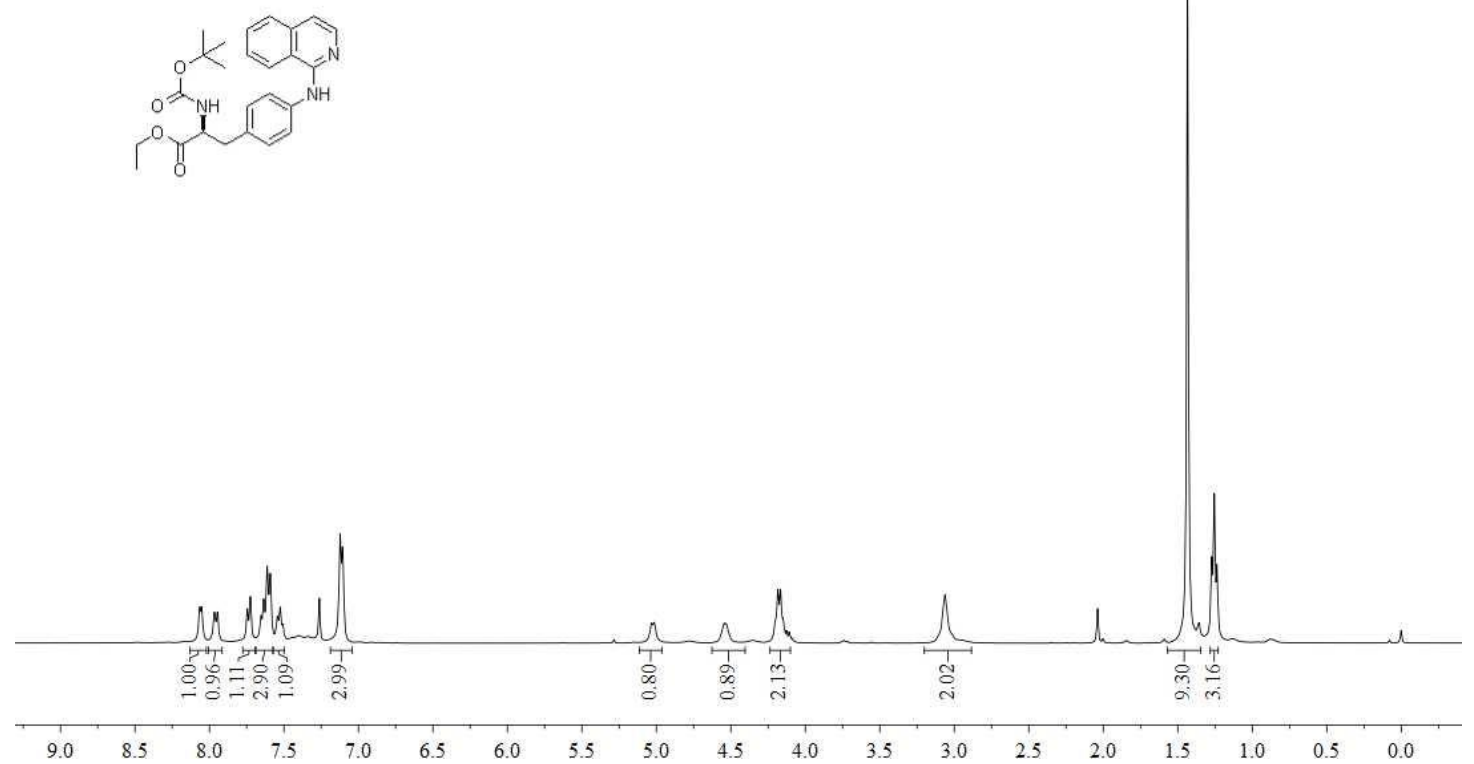

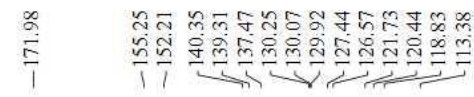

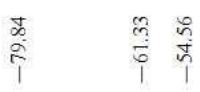

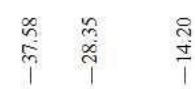

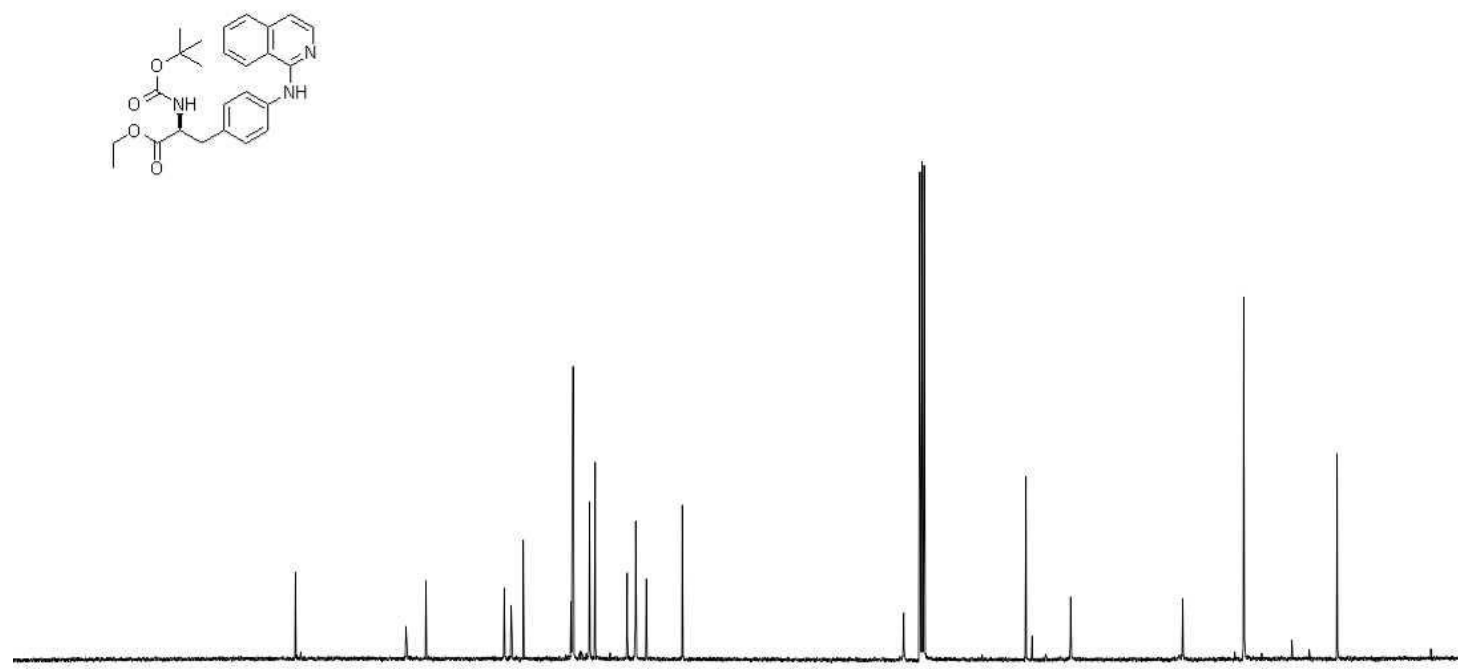

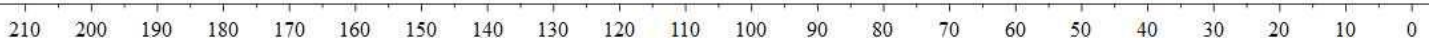


isoquinolin-1-amine (59c)

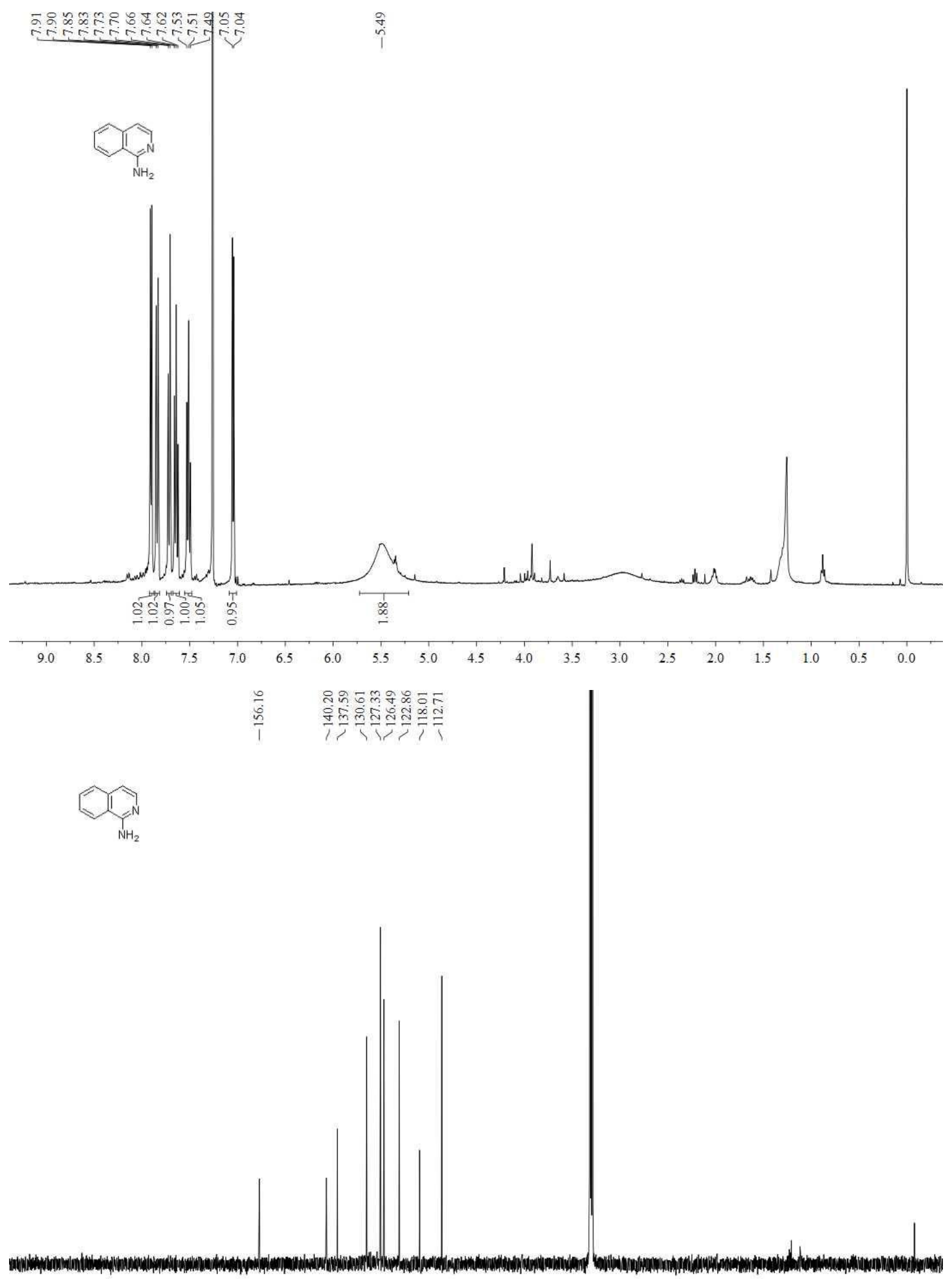

$\begin{array}{lllllllllllllllllllllllllll}210 & 200 & 190 & 180 & 170 & 160 & 150 & 140 & 130 & 120 & 110 & 100 & 90 & 80 & 70 & 60 & 50 & 40 & 30 & 20 & 10 & 0\end{array}$ 
$N$-methylisoquinolin-1-amine (60c)

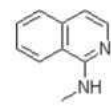

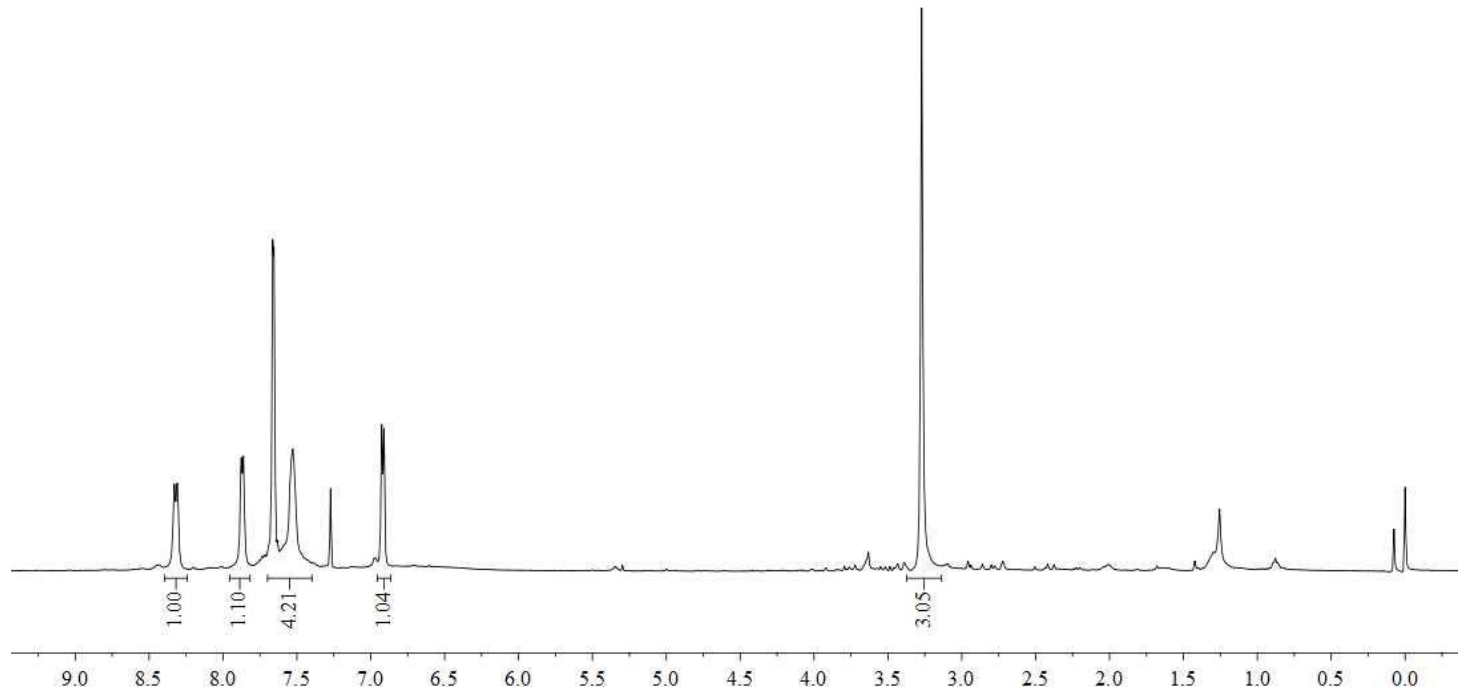

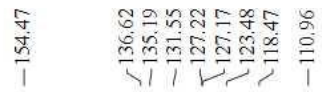
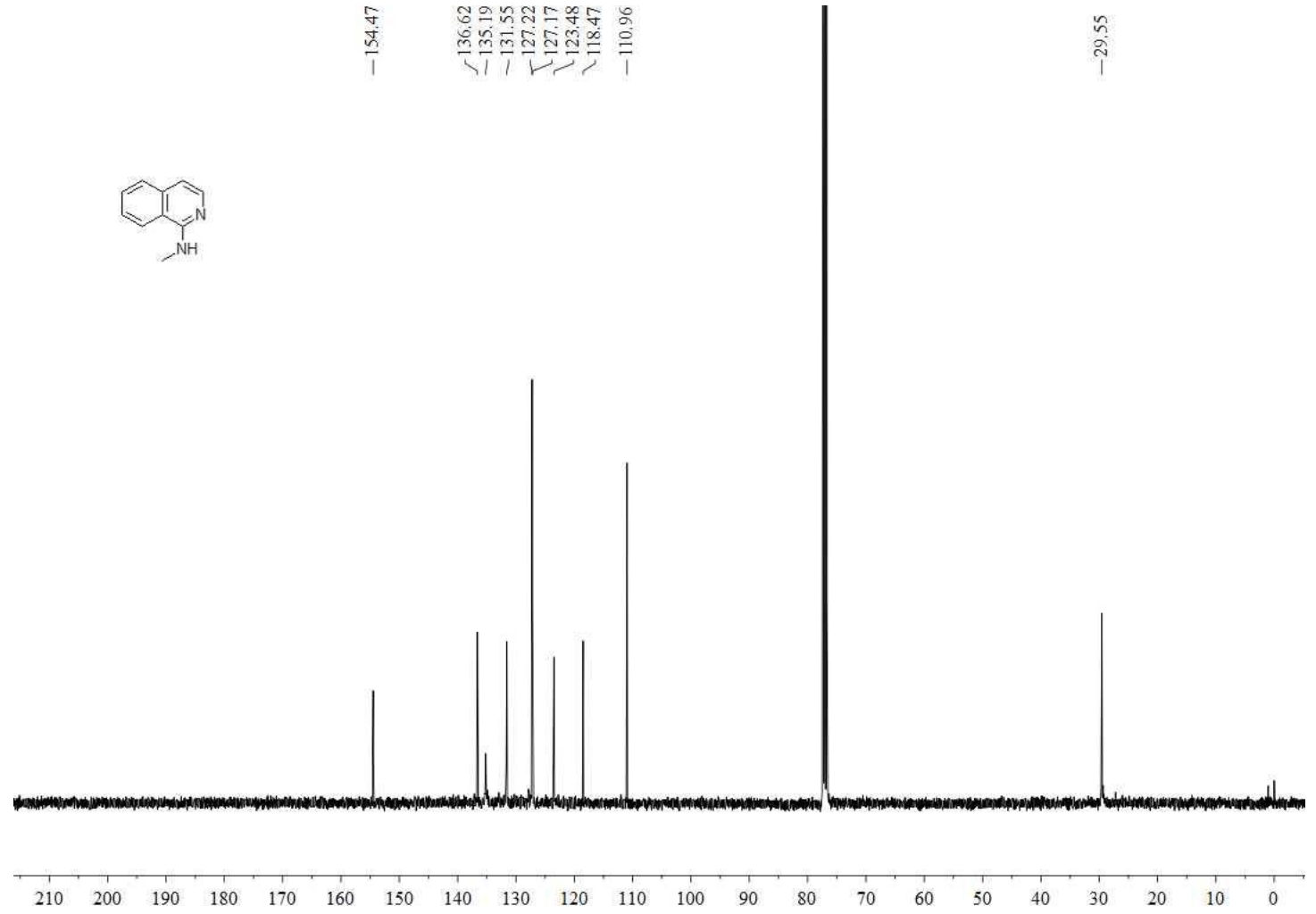
$N$-ethylisoquinolin-1-amine (61c)
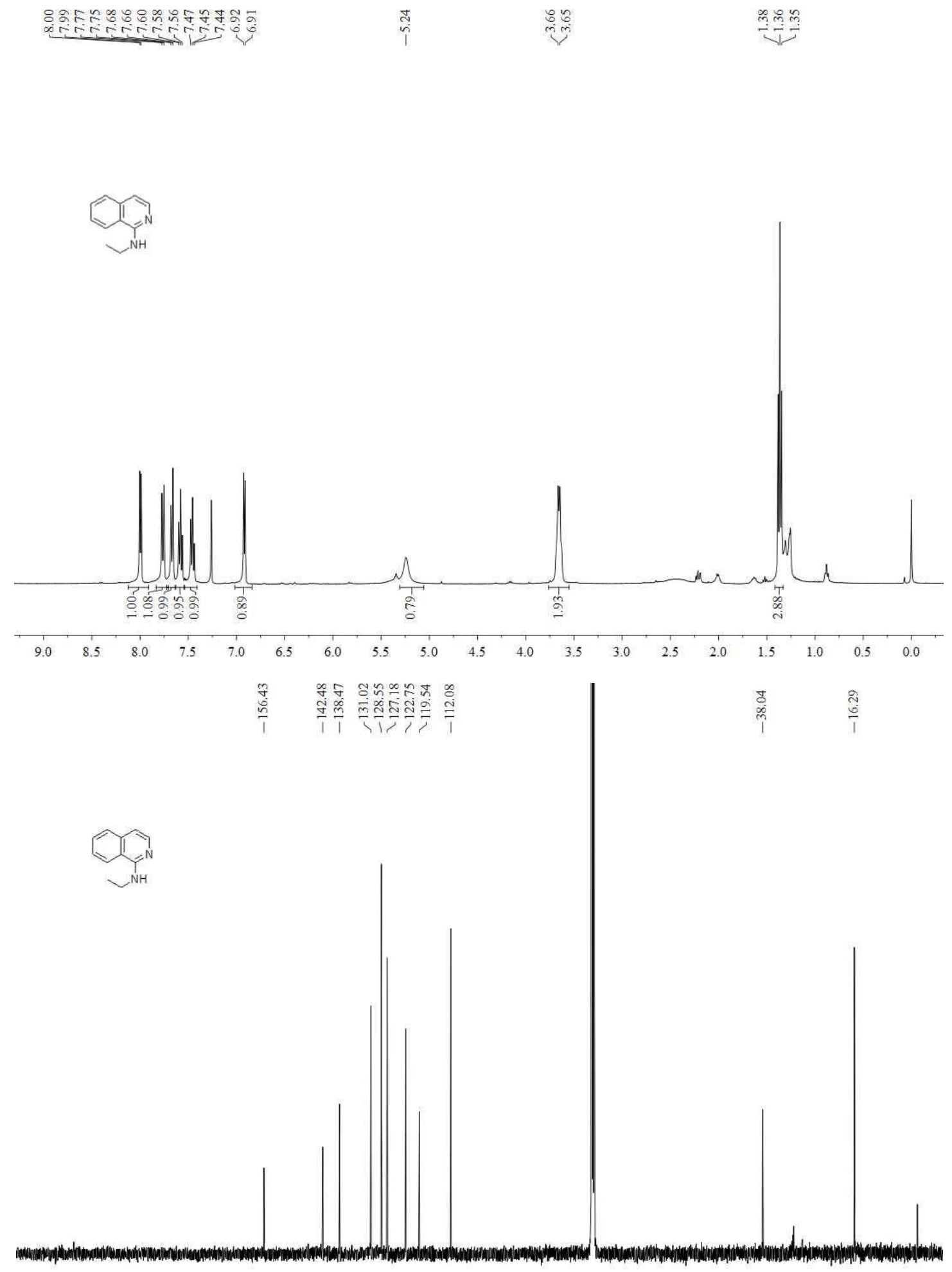

$\begin{array}{llllllllllllllllllllllllllll}210 & 200 & 190 & 180 & 170 & 160 & 150 & 140 & 130 & 120 & 110 & 100 & 90 & 80 & 70 & 60 & 50 & 40 & 30 & 20 & 10 & 0\end{array}$ 
$N$-isopropylisoquinolin-1-amine (62c)
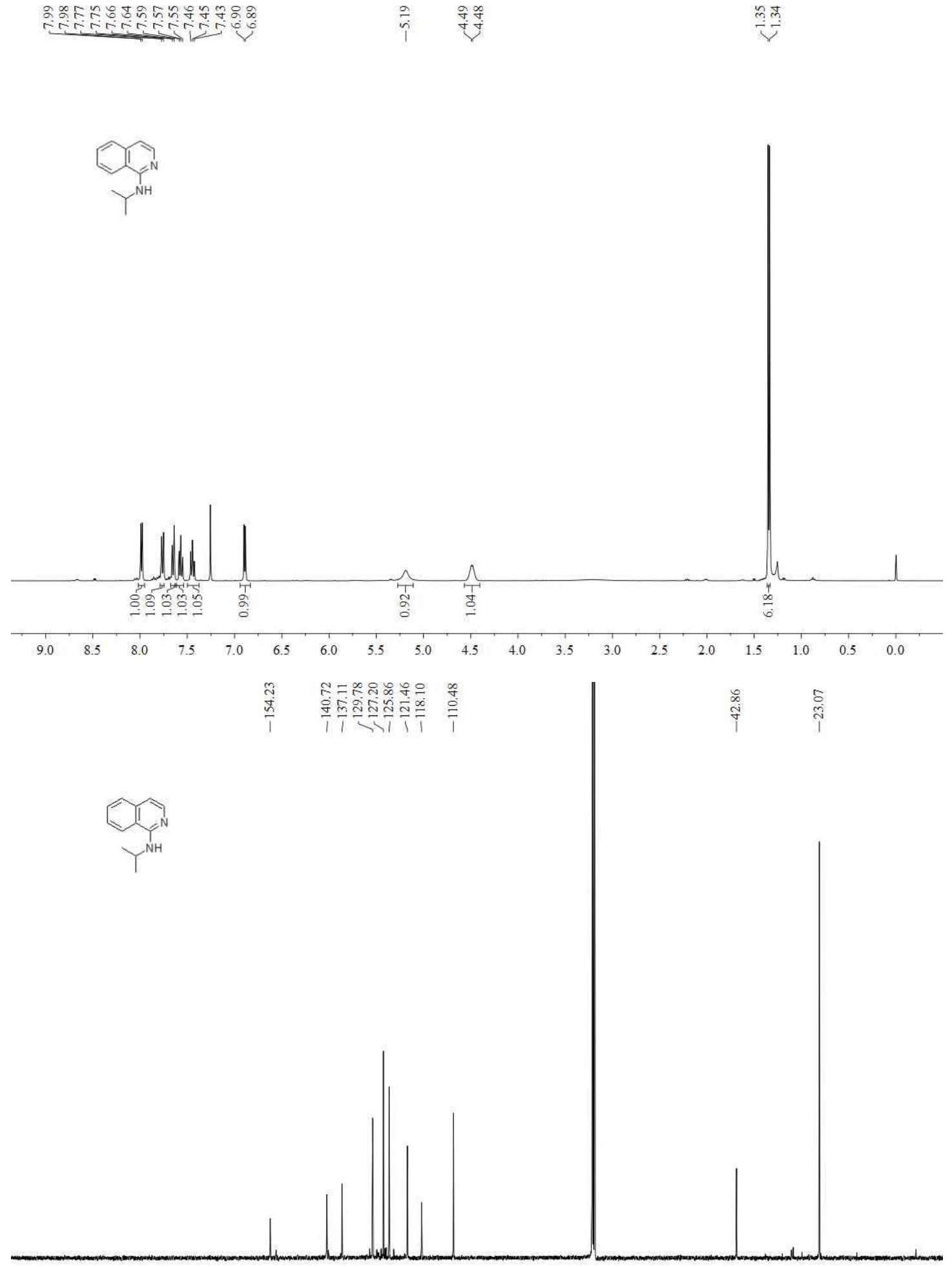

$\begin{array}{lllllllllllllllllllllll}210 & 200 & 190 & 180 & 170 & 160 & 150 & 140 & 130 & 120 & 110 & 100 & 90 & 80 & 70 & 60 & 50 & 40 & 30 & 20 & 10 & 0\end{array}$ 
$N$-neopentylisoquinolin-1-amine (63c)
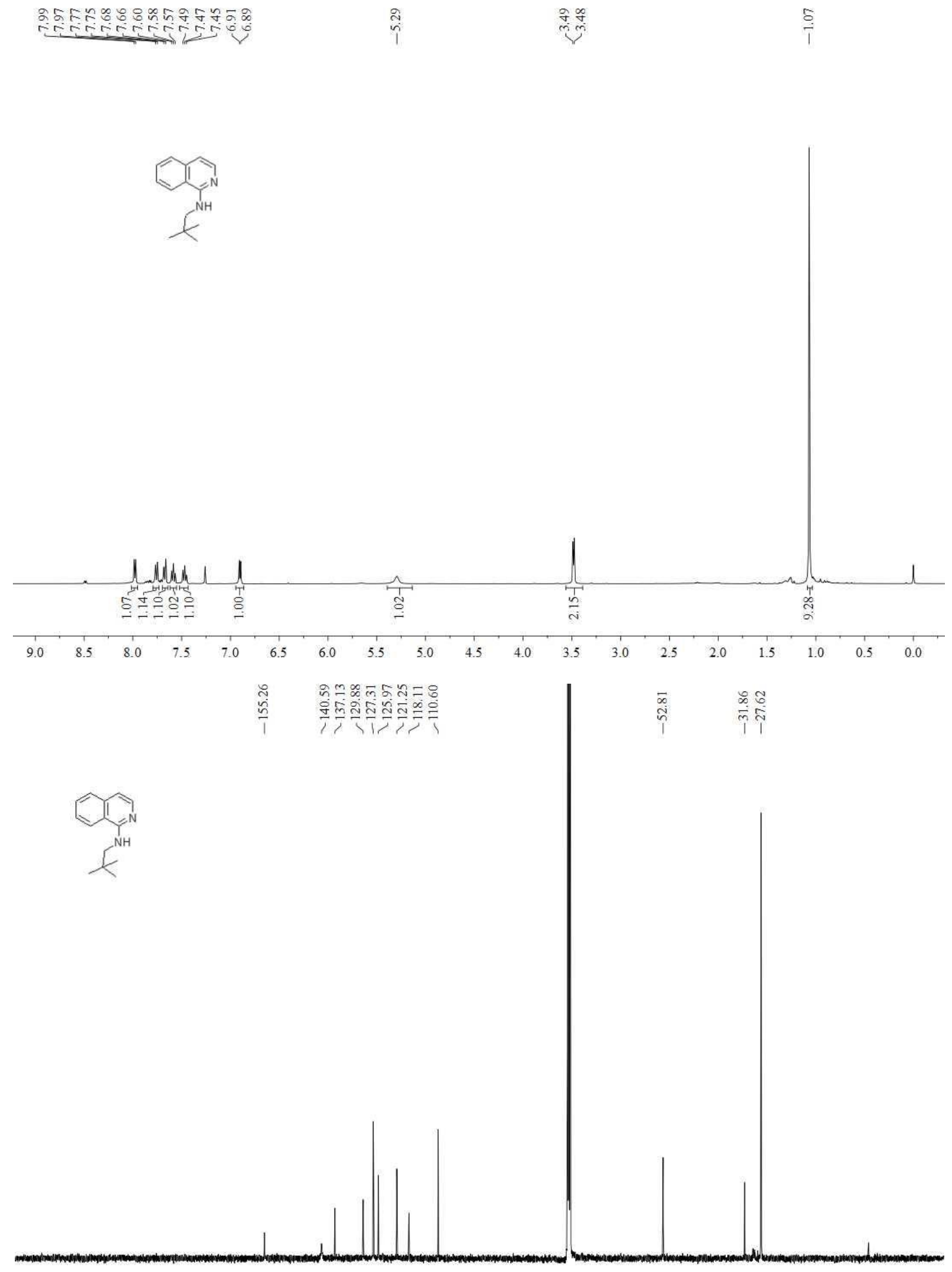

$\begin{array}{lllllllllllllllllllllllllll}210 & 200 & 190 & 180 & 170 & 160 & 150 & 140 & 130 & 120 & 110 & 100 & 90 & 80 & 70 & 60 & 50 & 40 & 30 & 20 & 10 & 0 & -10\end{array}$ 


\section{$\mathrm{N}$-benzylisoquinolin-1-amine (64c)}

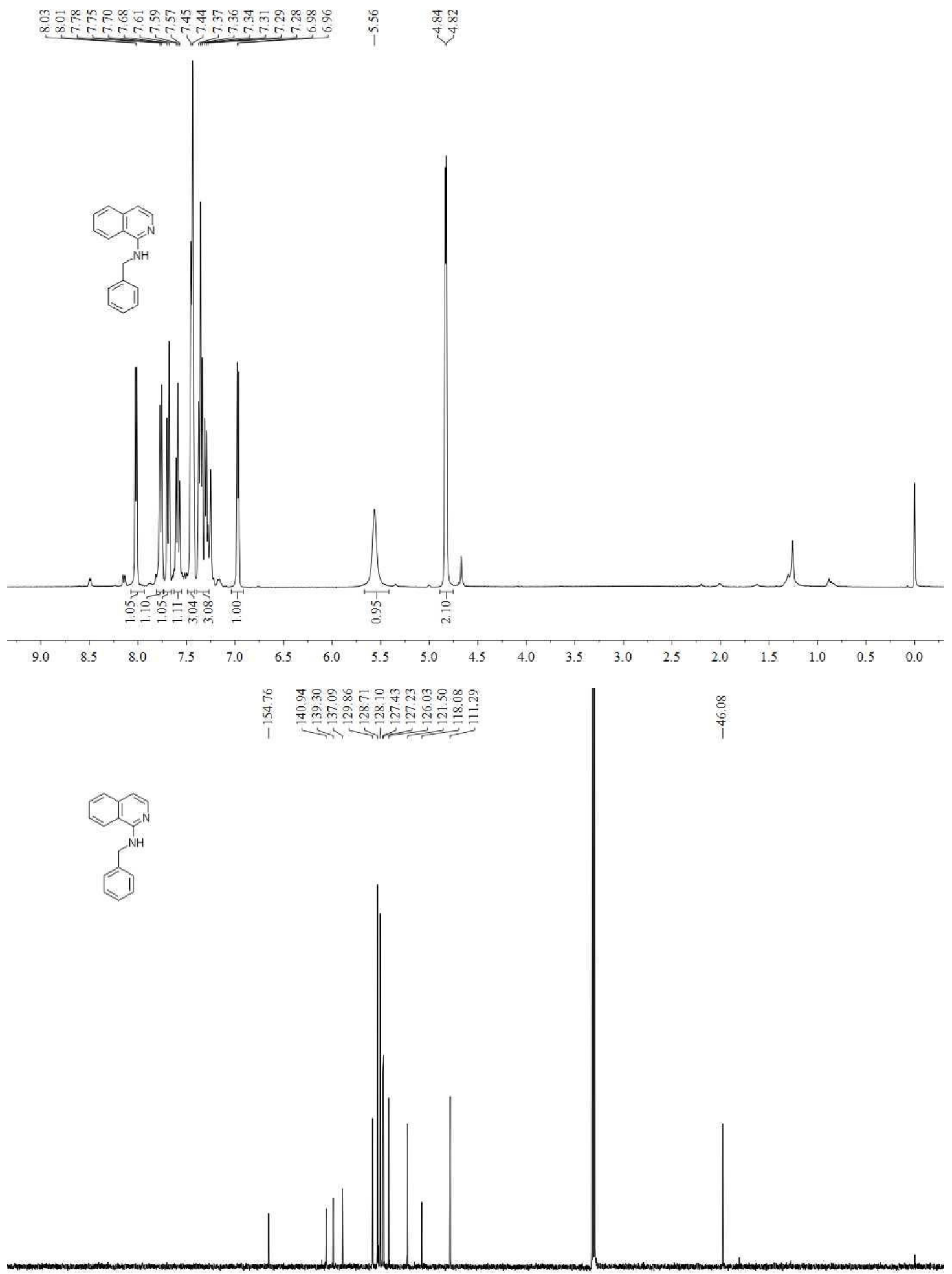

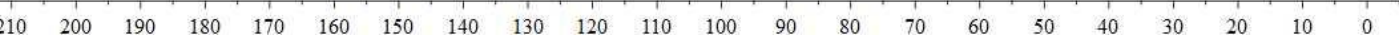




\section{$N$-cyclobutylisoquinolin-1-amine $(65 \mathrm{c})$}

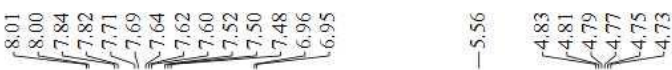

ํำ
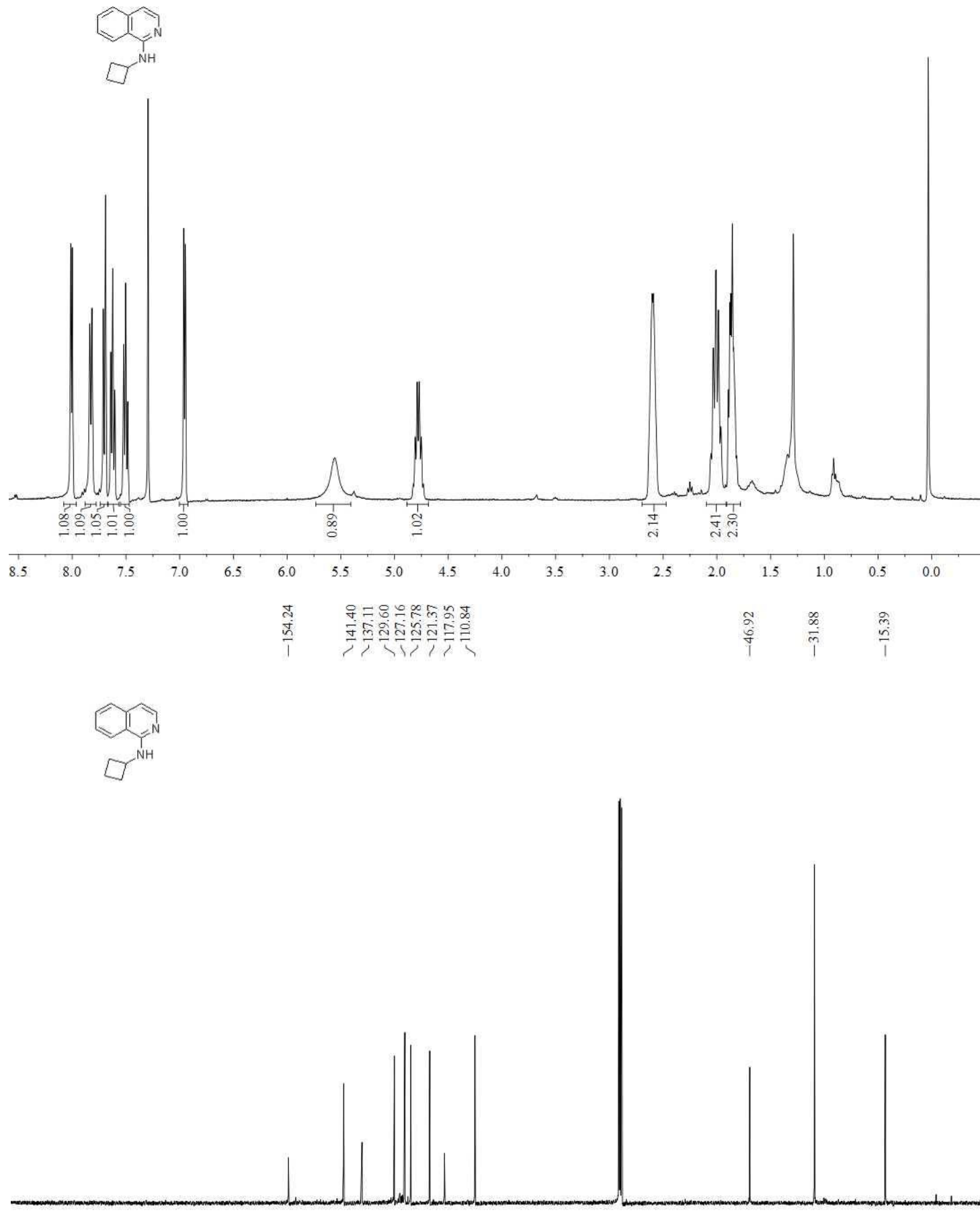

$\begin{array}{lllllllllllllllllllllllllll}210 & 200 & 190 & 180 & 170 & 160 & 150 & 140 & 130 & 120 & 110 & 100 & 90 & 80 & 70 & 60 & 50 & 40 & 30 & 20 & 10 & 0\end{array}$ 
$N$-cyclopentylisoquinolin-1-amine (66c)

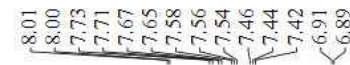

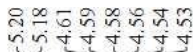

ปูกสำกำ

$\overbrace{N}$

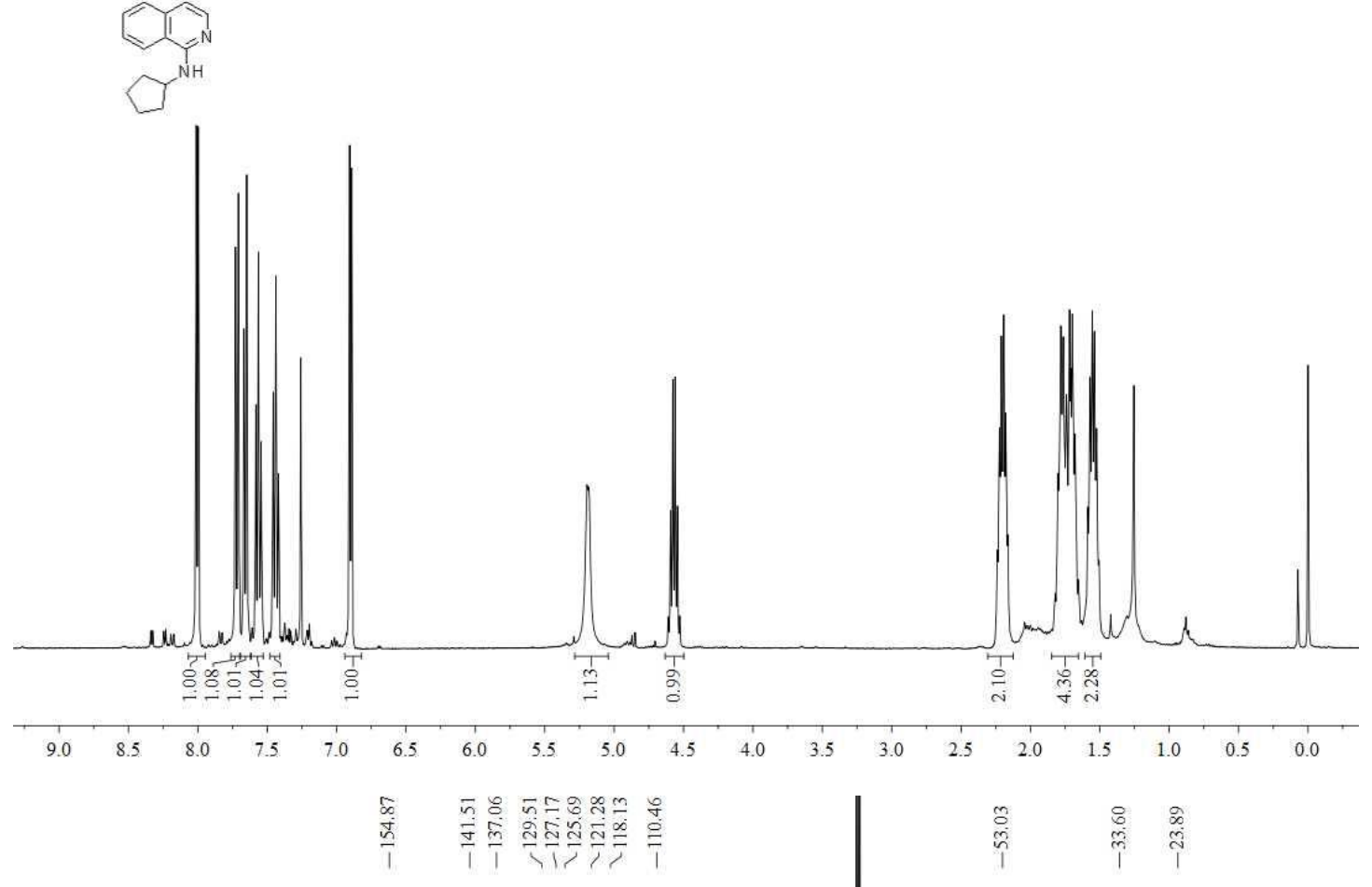

$\vartheta^{N+N}$
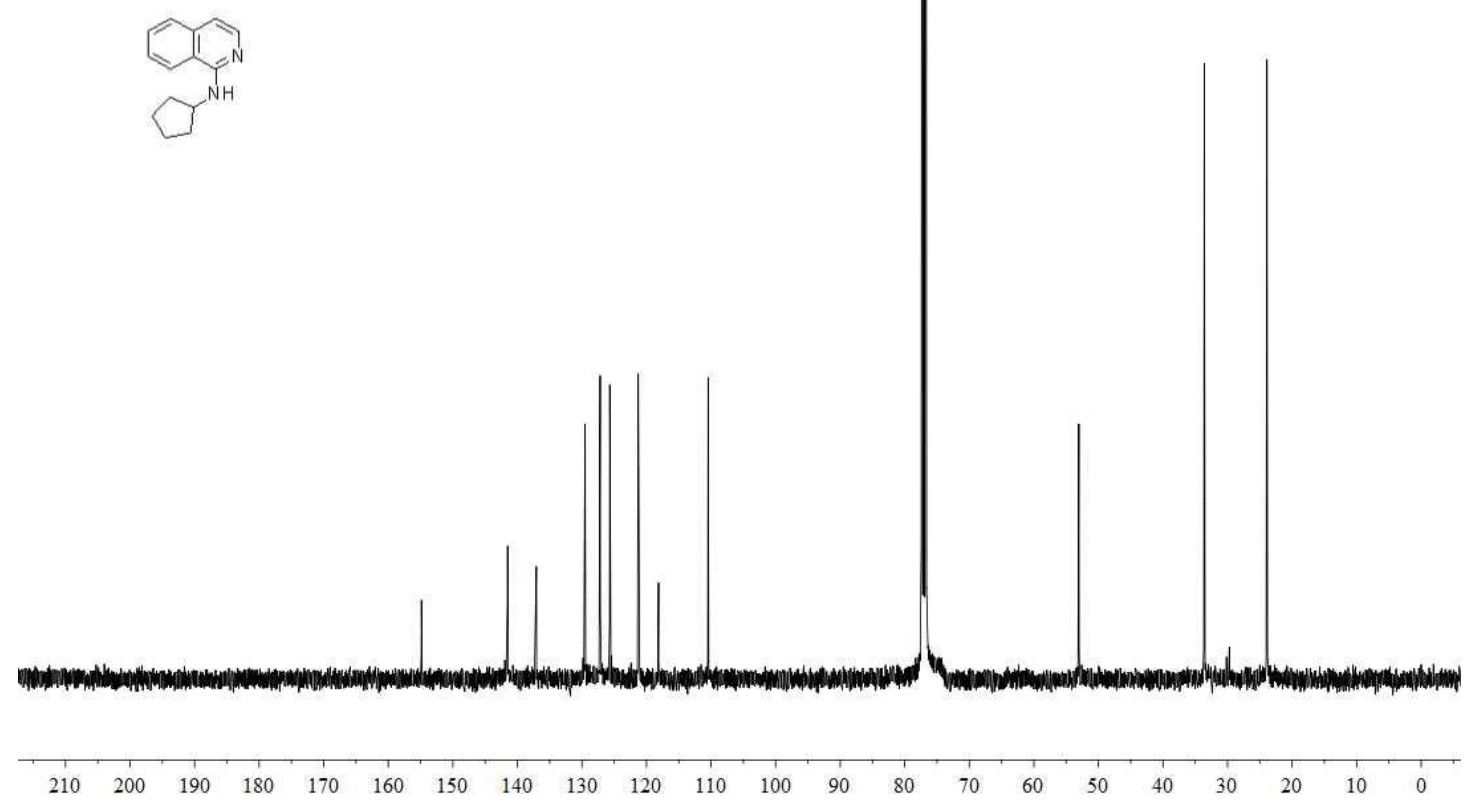

$70 \quad 60$

$50 \quad 40$

$\begin{array}{llll}30 & 20 & 10 & 0\end{array}$ 
$\mathrm{N}$-cyclohexylisoquinolin-1-amine (67c)

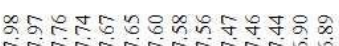

mivisising

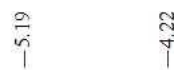

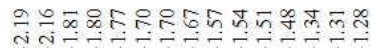
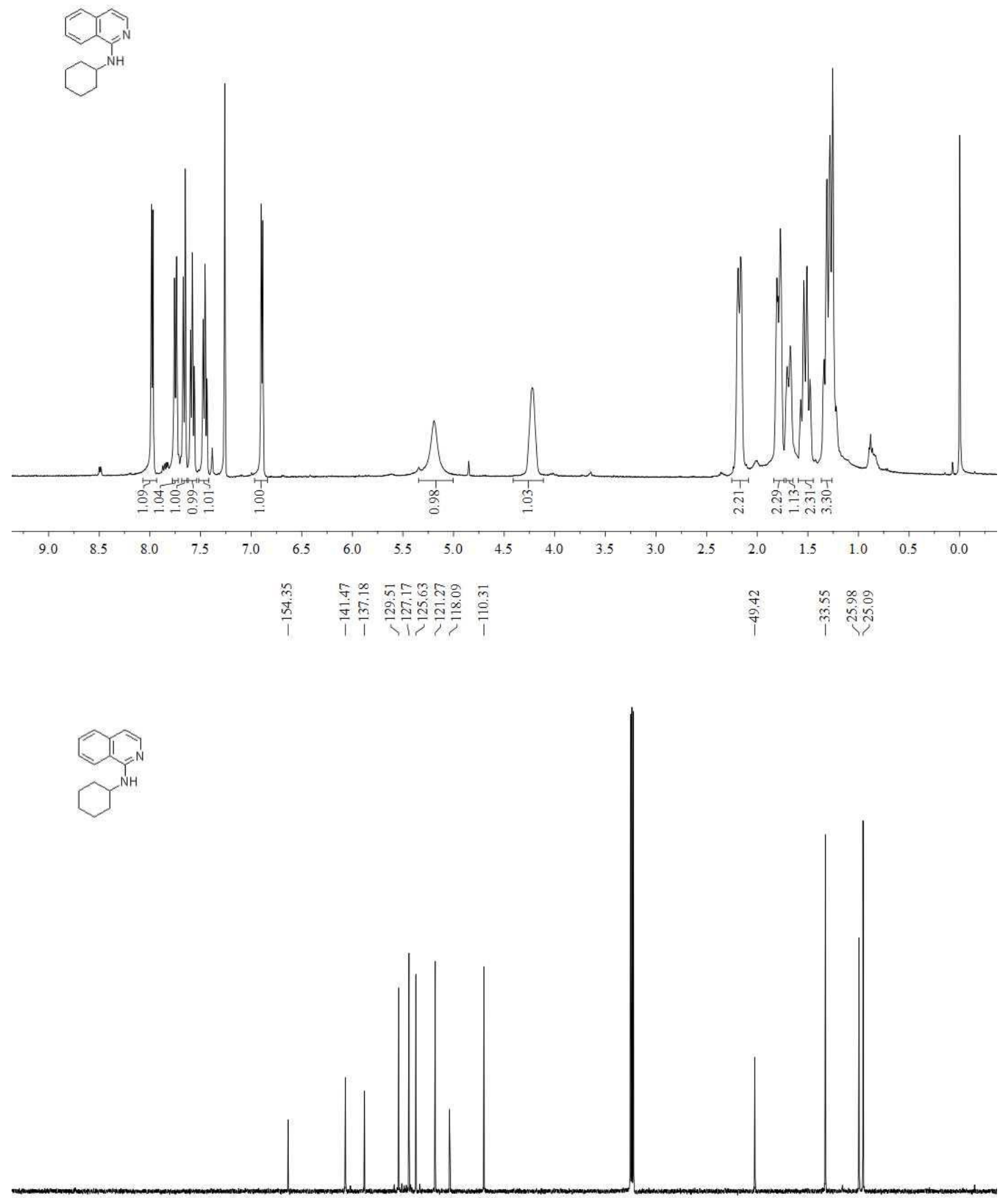


\section{4-(isoquinolin-1-ylamino)cyclohexanol (68c)}

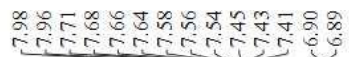

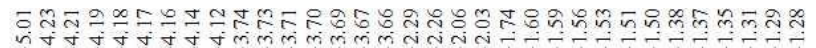<smiles>OC1CCC(Nc2nccc3ccccc23)CC1</smiles>

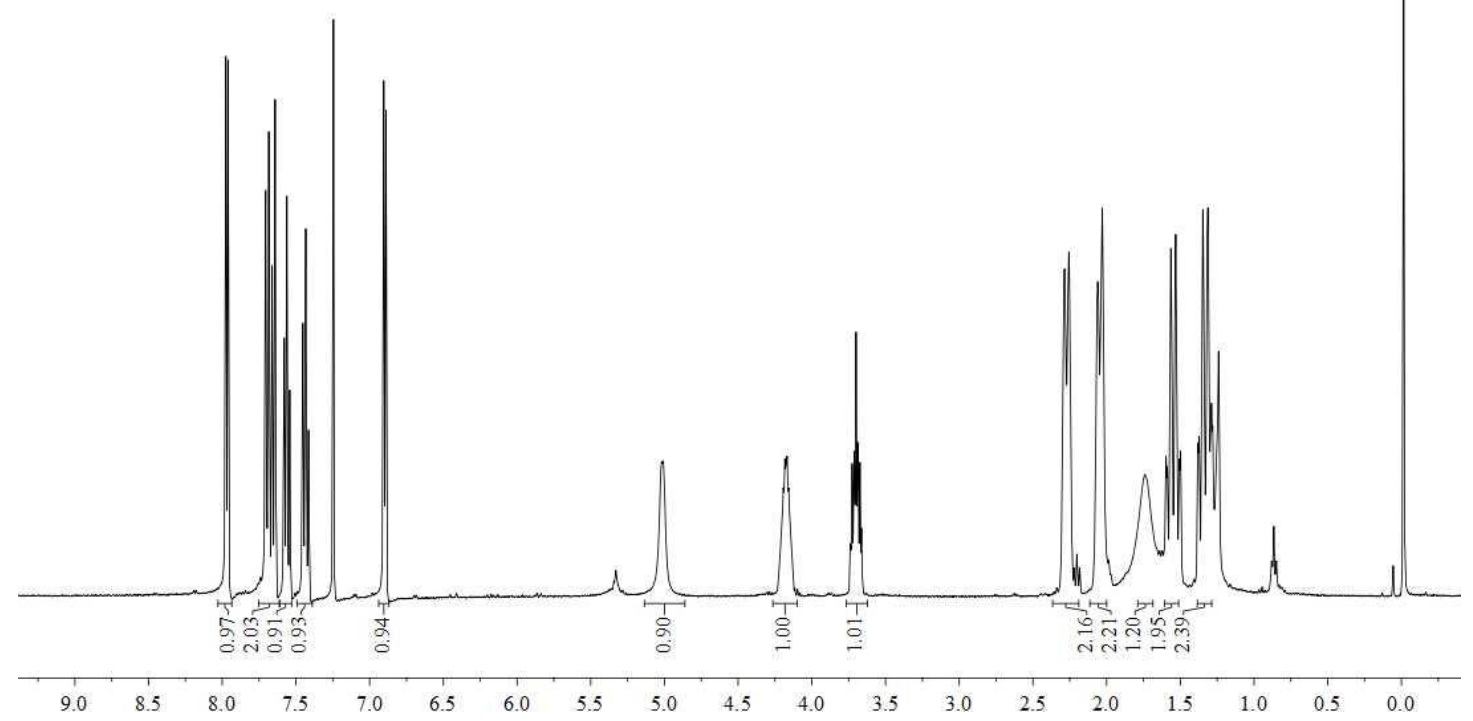

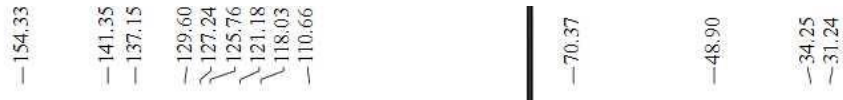

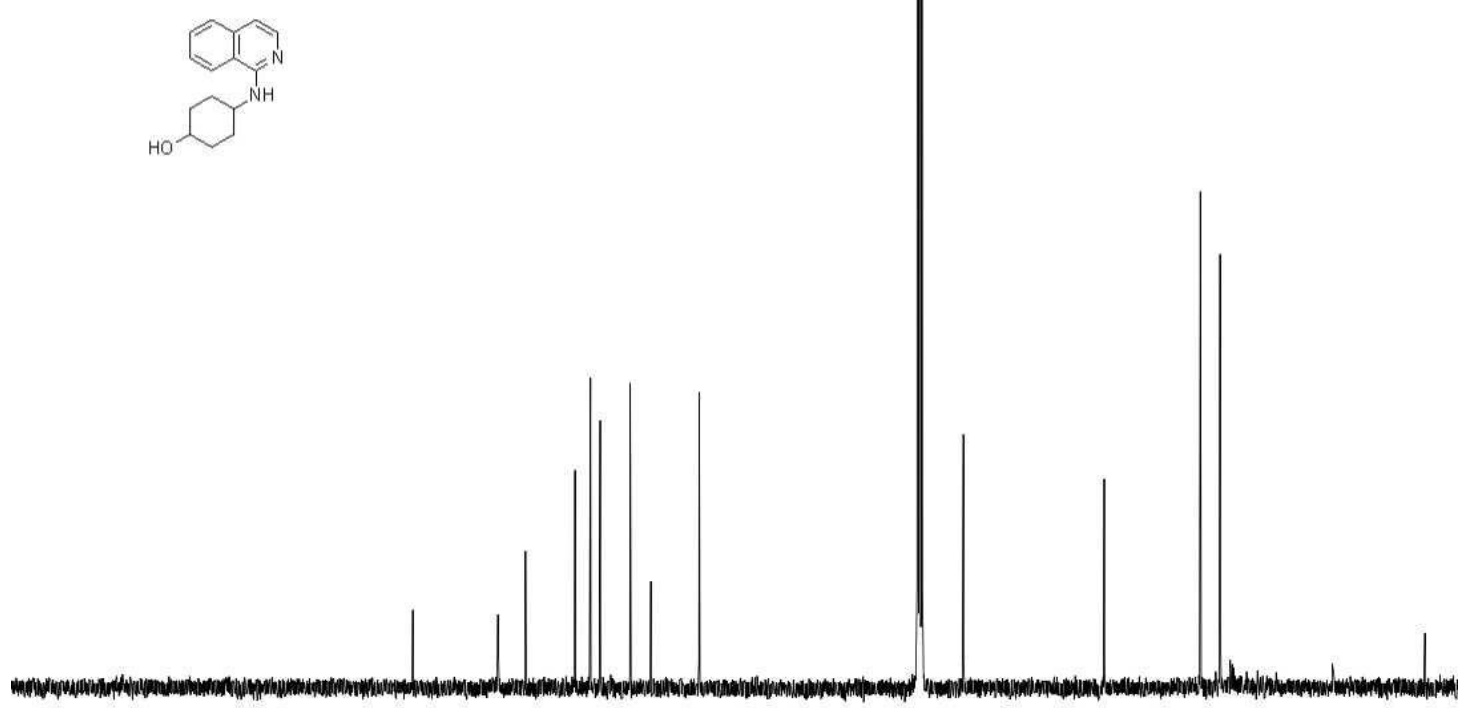

$\begin{array}{llllllllllllllllllllllll}210 & 200 & 190 & 180 & 170 & 160 & 150 & 140 & 130 & 120 & 110 & 100 & 90 & 80 & 70 & 60 & 50 & 40 & 30 & 20 & 10 & 0\end{array}$ 
$N$-(4-(isoquinolin-1-ylamino)cyclohexyl)acetamide (69c)

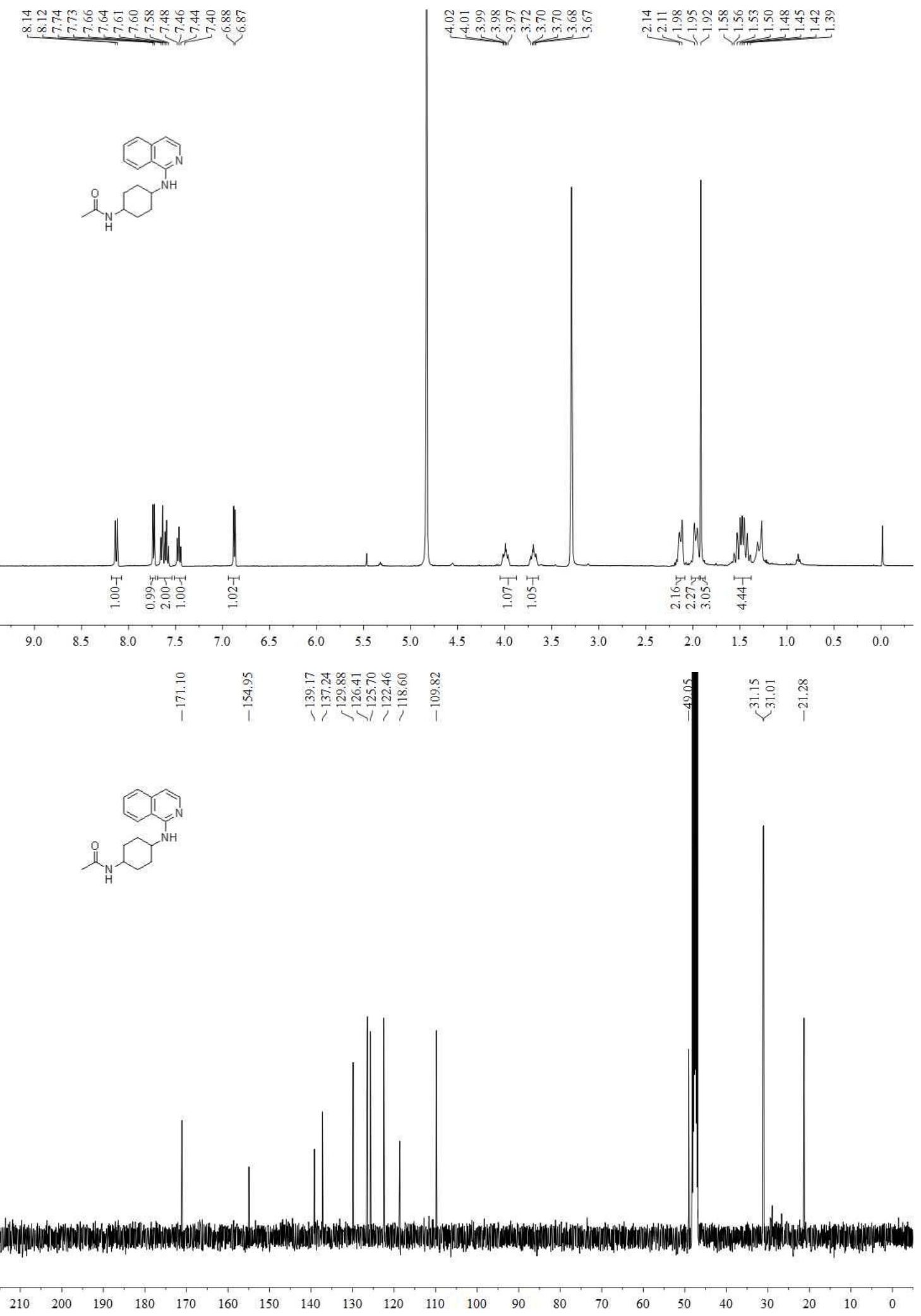




\section{6-bromo- $N$-methylisoquinolin-1-amine (70c)}

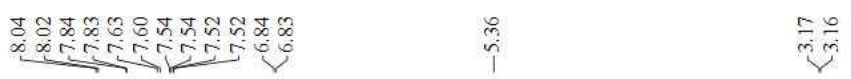

NH

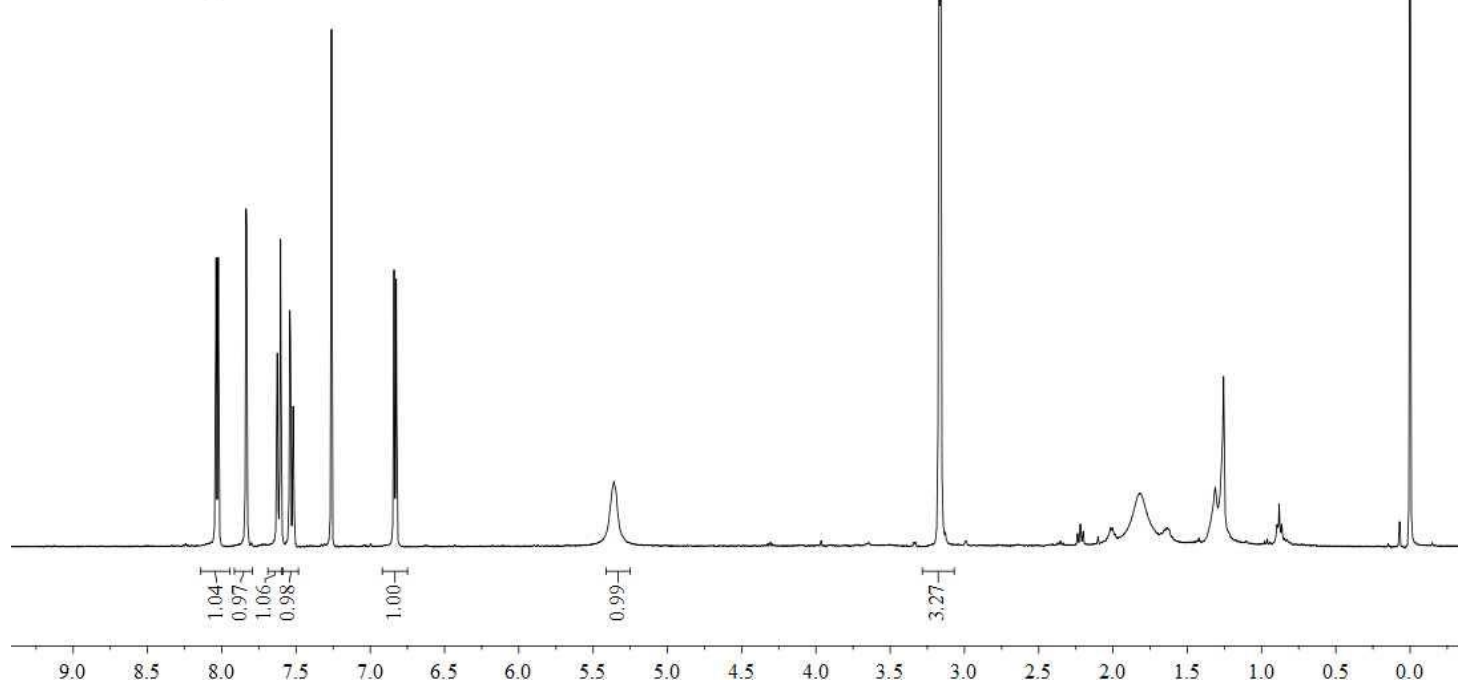

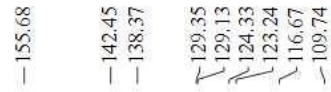
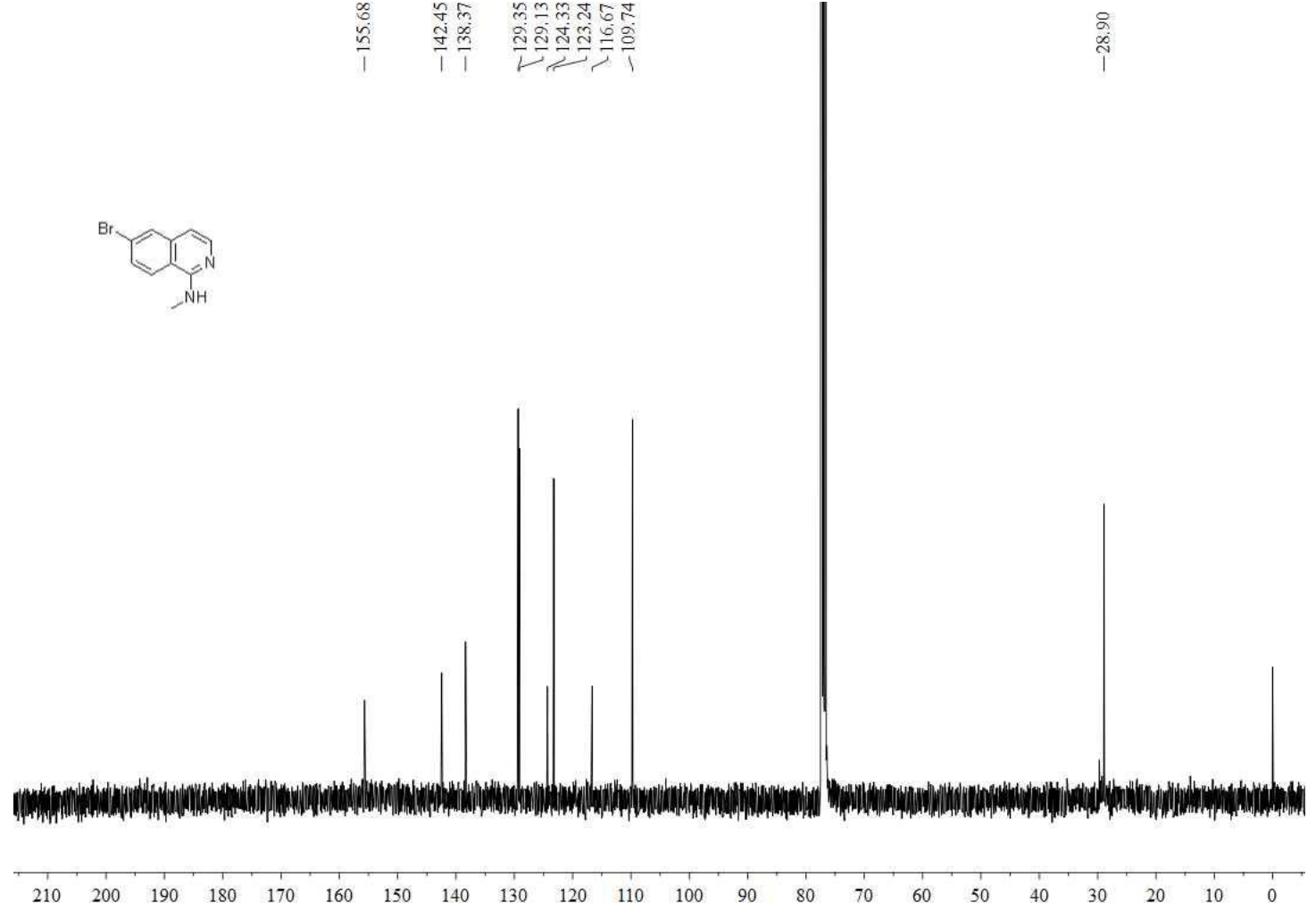
$N$-methylquinolin-2-amine (71c)

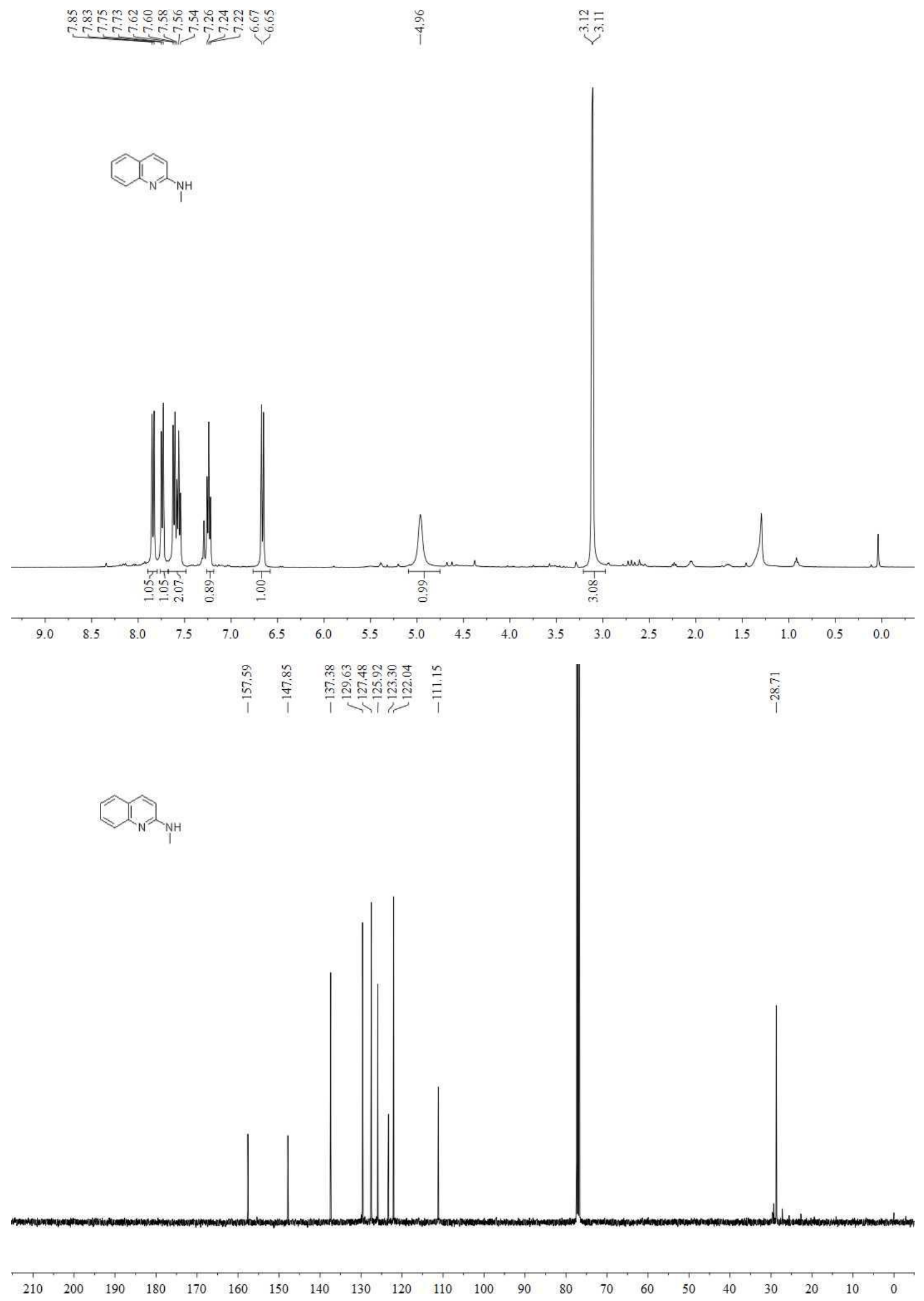




\section{$N, 4-d i m e t h y l q u i n o l i n-2-a m i n e ~(72 c)$}

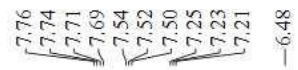

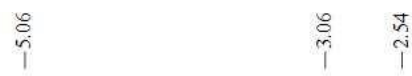

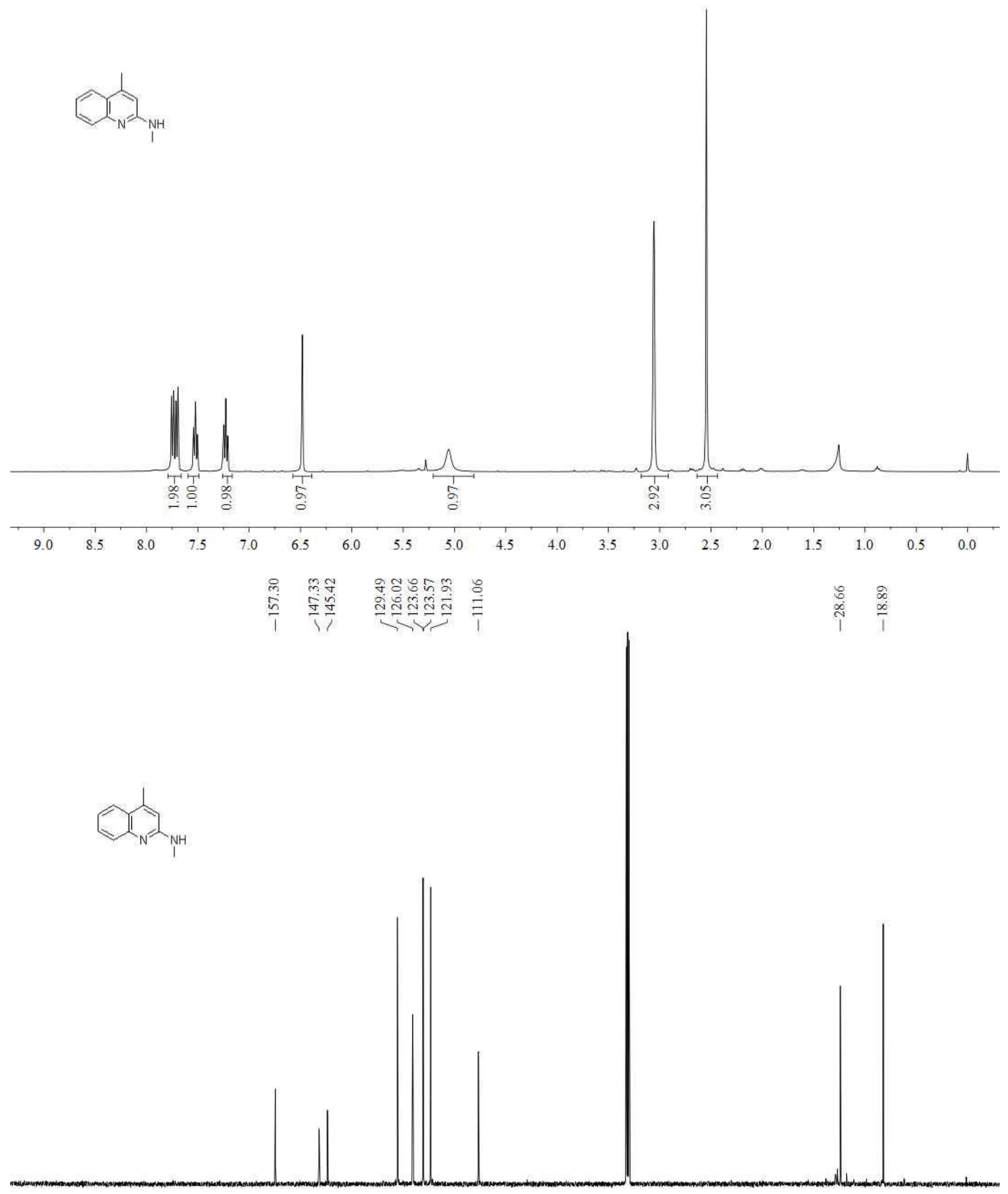

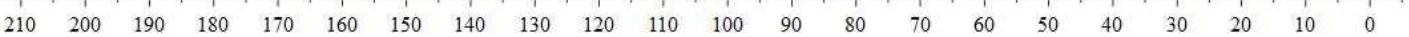


6-bromo- $N$-methylquinolin-2-amine (73c)
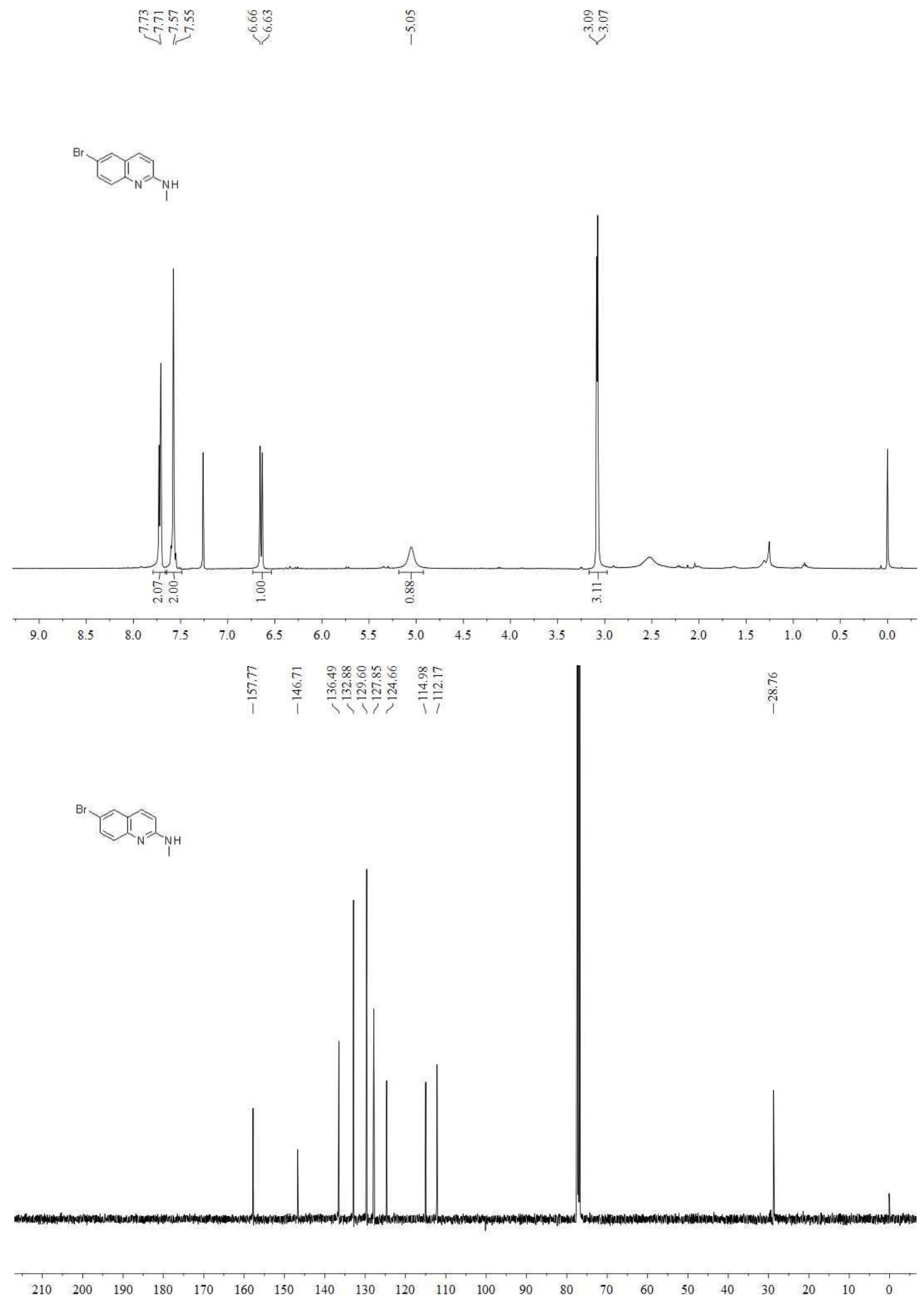
$N$-(tert-butyl)isoquinolin-1-amine (74c)
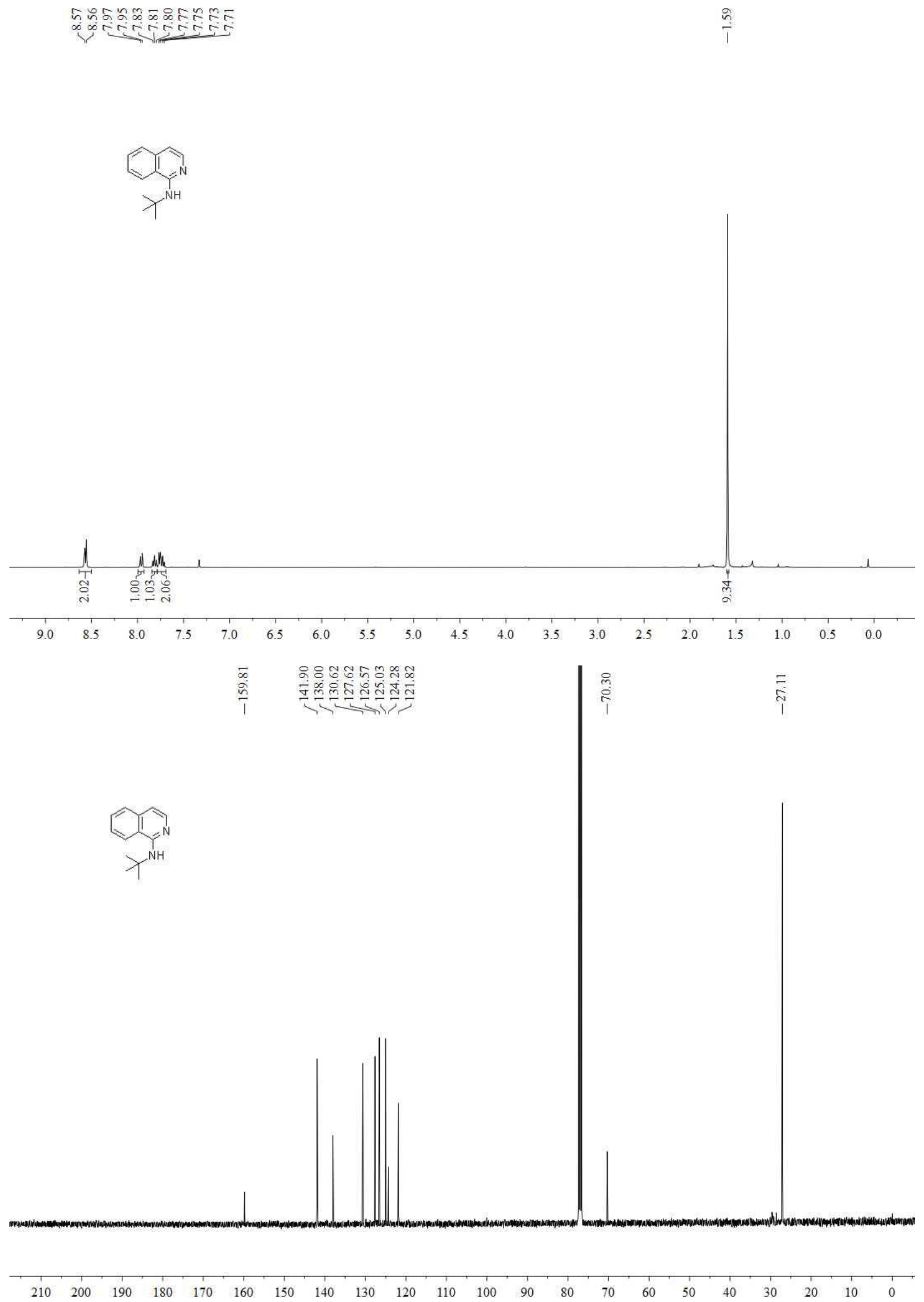


\section{$N$-(4-methoxyphenyl)quinolin-2-amine (75c)}

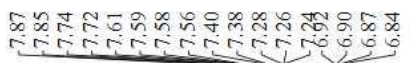

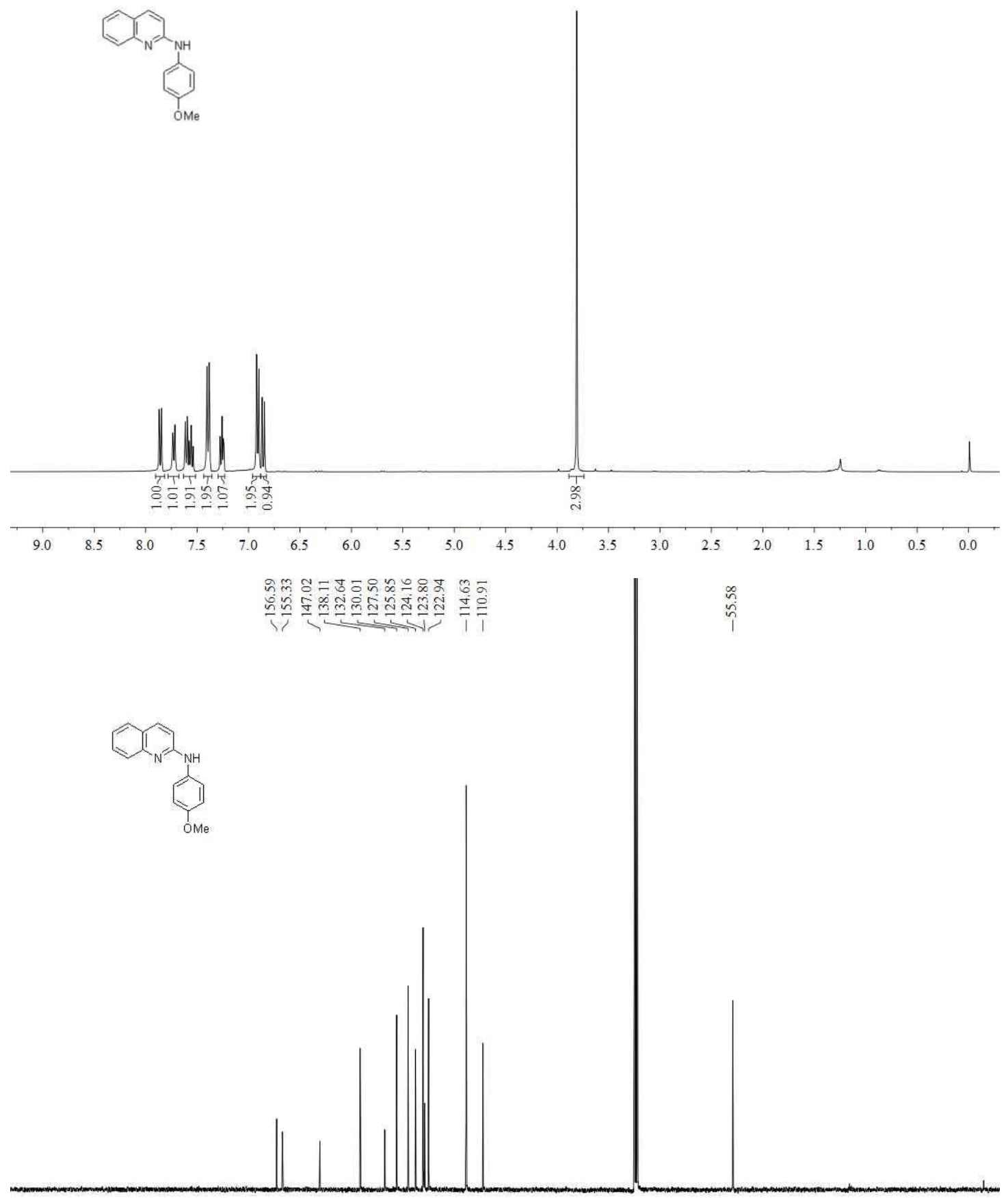

$\begin{array}{llllllllllllllllllll}210 & 200 & 190 & 180 & 170 & 160 & 150 & 140 & 130 & 120 & 110 & 100 & 90 & 80 & 70 & 60 & 50 & 40 & 30 & 20\end{array}$ 


\section{$N$-(4-methoxyphenyl)pyridin-4-amine (76c)}
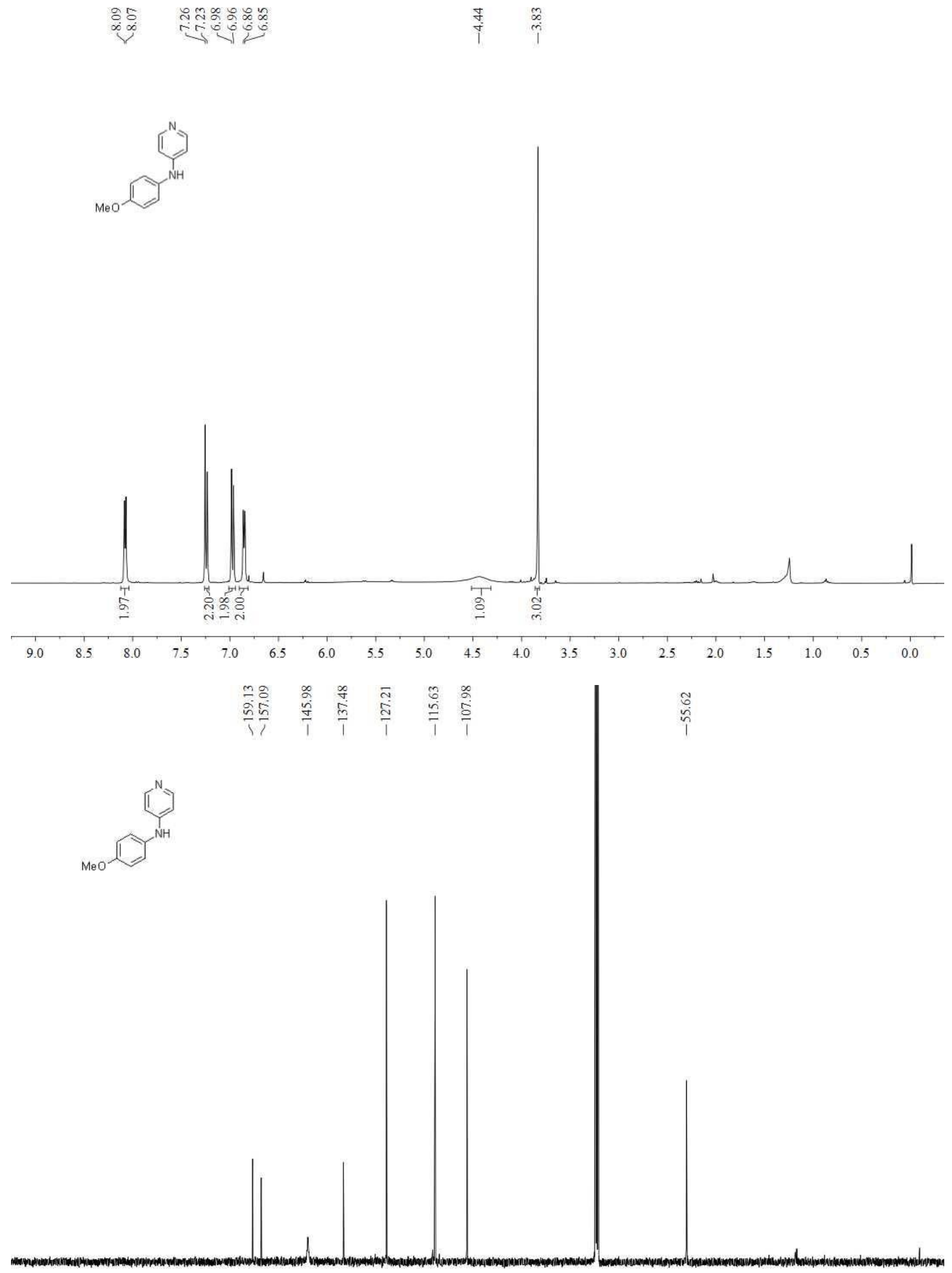
$N$-(4-methoxyphenyl)pyrimidin-2-amine (77c)

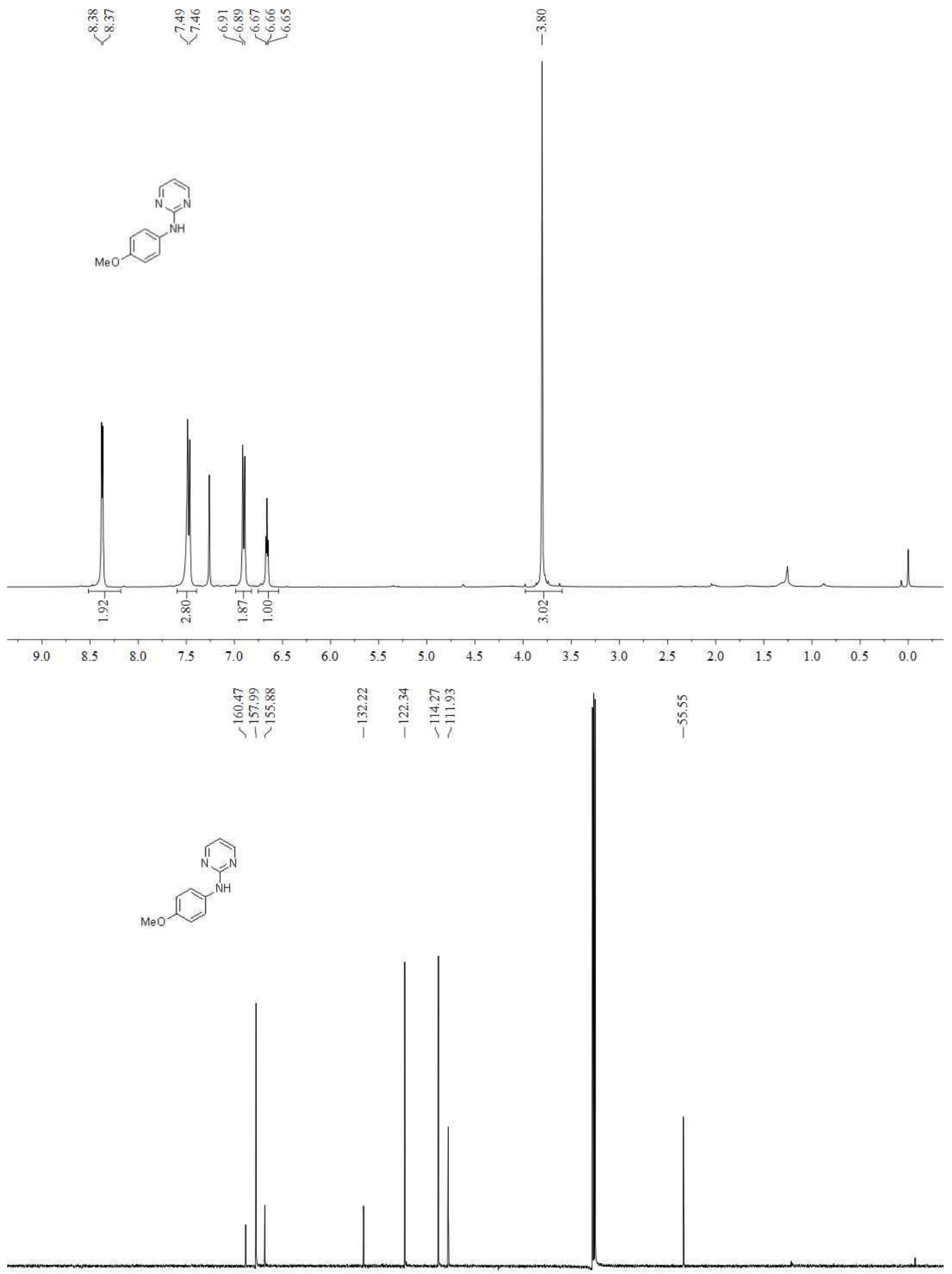

$\begin{array}{lllllllllllllllllllllllllll}210 & 200 & 190 & 180 & 170 & 160 & 150 & 140 & 130 & 120 & 110 & 100 & 90 & 80 & 70 & 60 & 50 & 40 & 30 & 20 & 10 & 0\end{array}$ 


\section{$N$-(4-methoxyphenyl)pyridazin-3-amine (78c)}

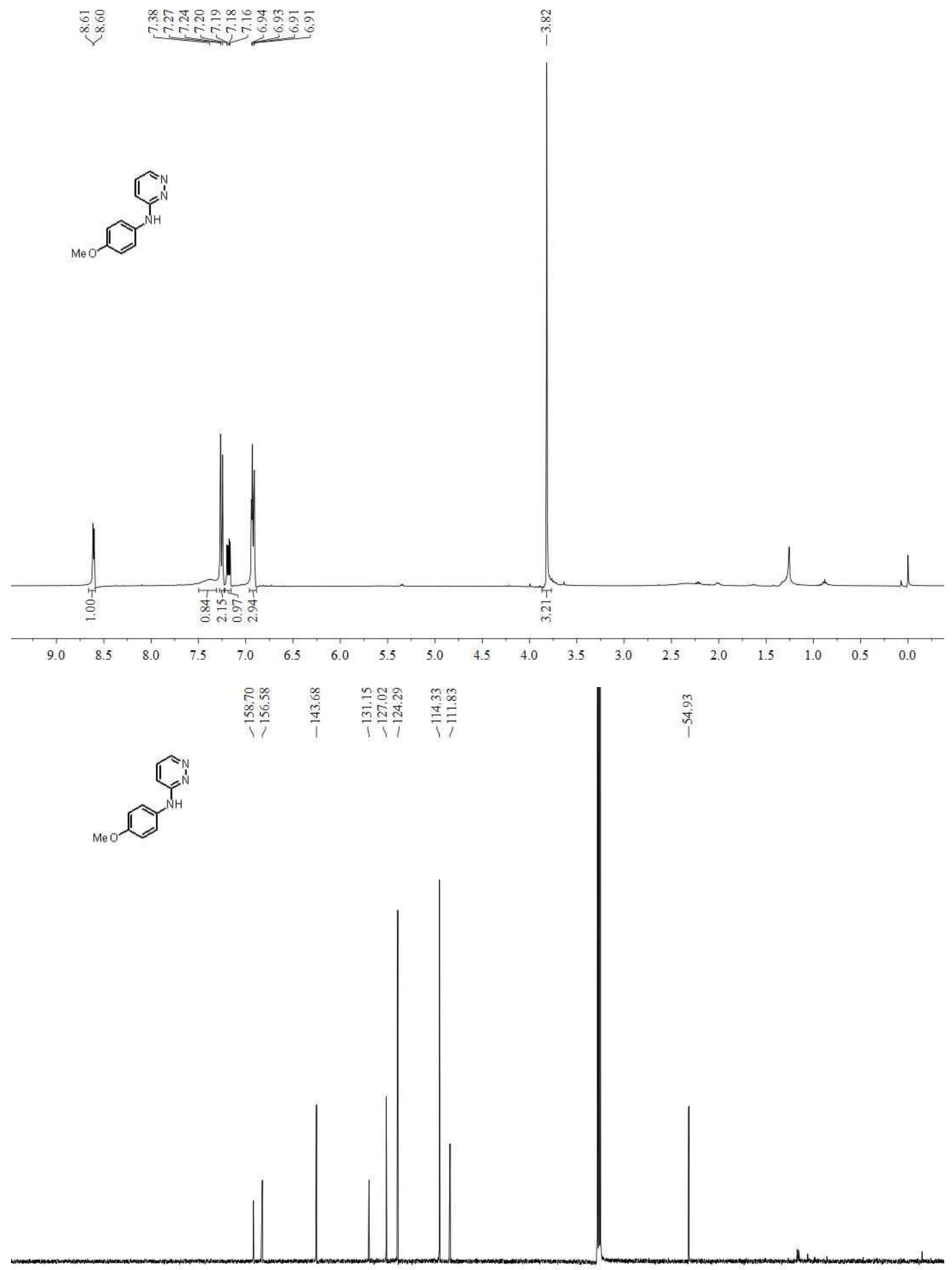

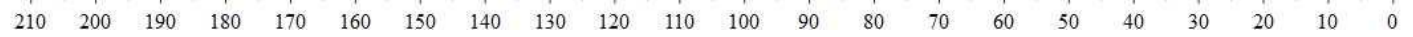




\section{$N$-(4-methoxyphenyl)thiazol-2-amine (79c)}

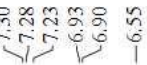

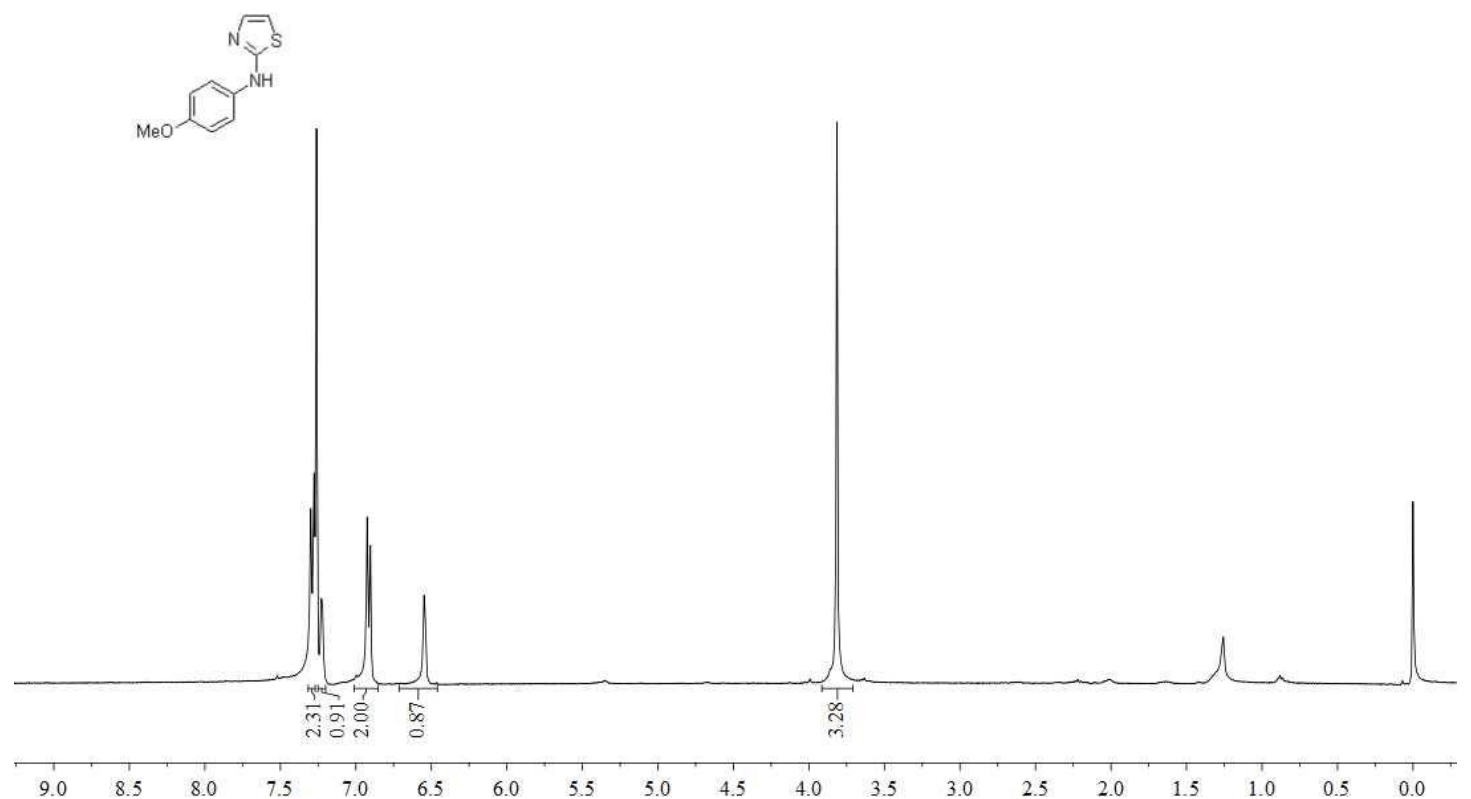

\begin{tabular}{|c|c|c|c|c|}
\hline $\begin{array}{l}n \\
\tilde{6} \\
\tilde{n}\end{array}$ & 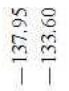 & $\frac{\stackrel{\infty}{\stackrel{N}{\Im}}}{1}$ & $\stackrel{\substack{\infty \\
\stackrel{D}{T}}}{T}$ & 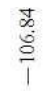 \\
\hline
\end{tabular}
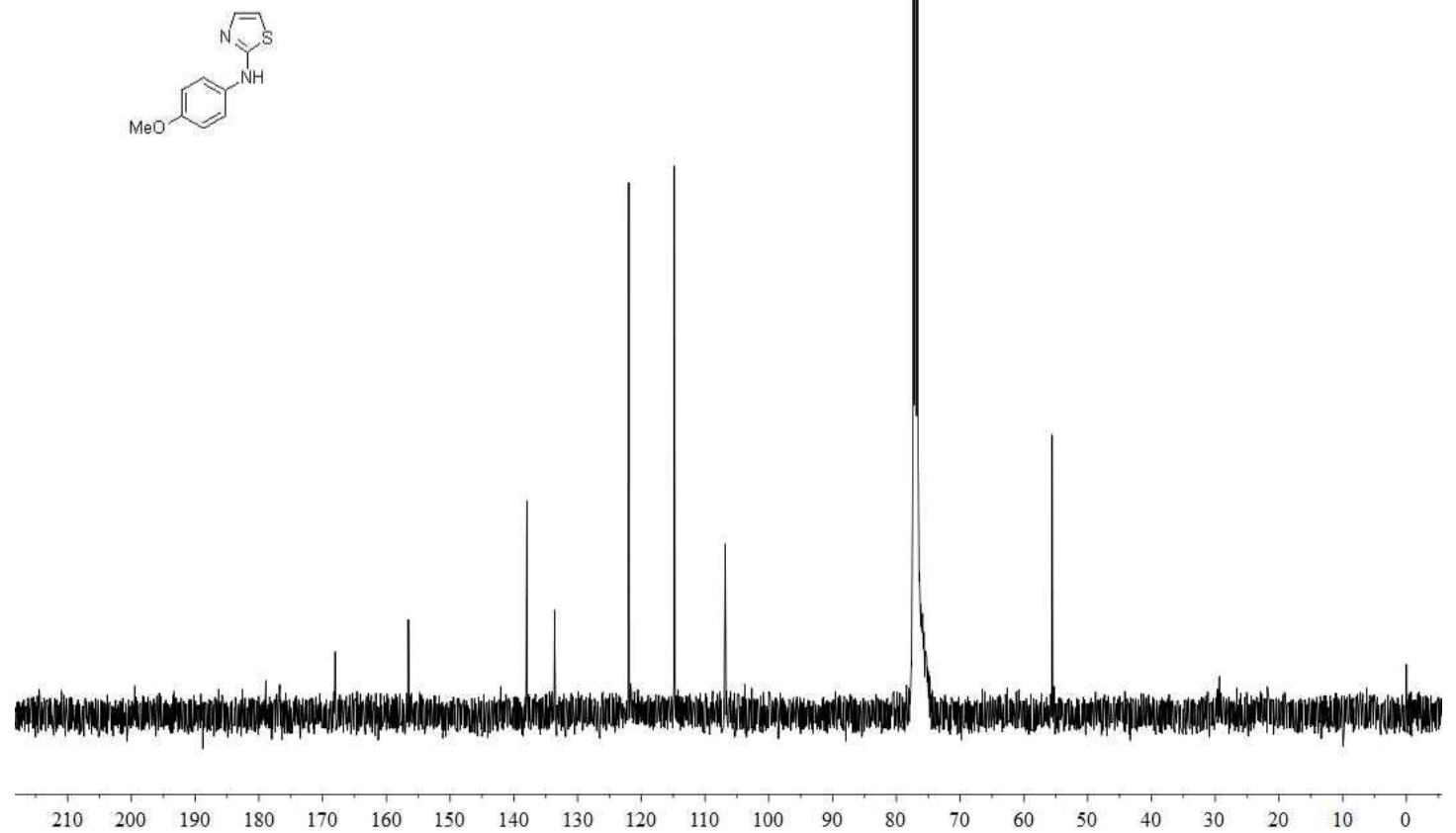


\section{$N$-(4-methoxyphenyl)-1H-pyrrolo[3,2-c]pyridin-4-amine (80c)}

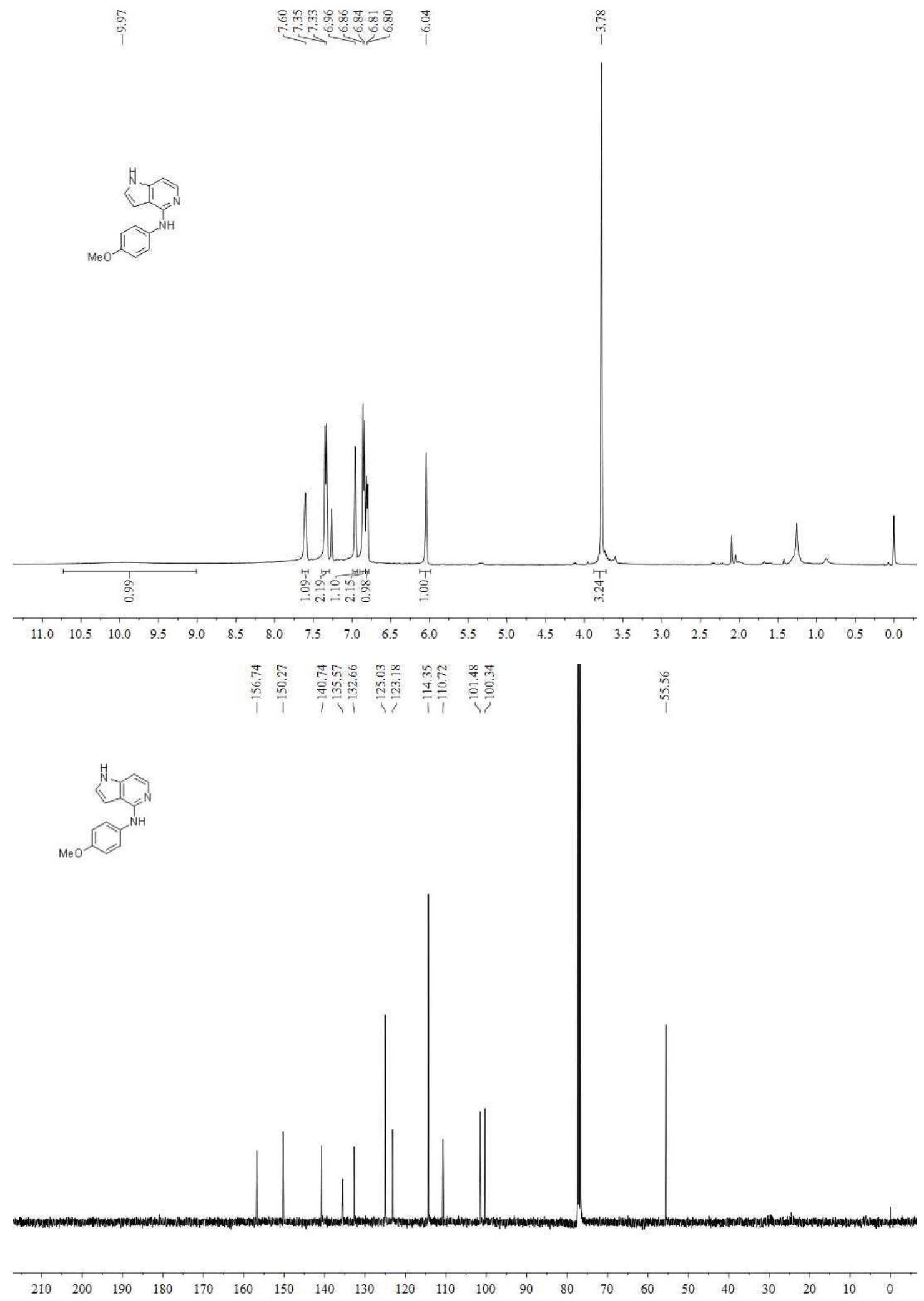


3-ethyl-3-(4-(isoquinolin-1-ylamino)phenyl)piperidine-2,6-dione (81c)

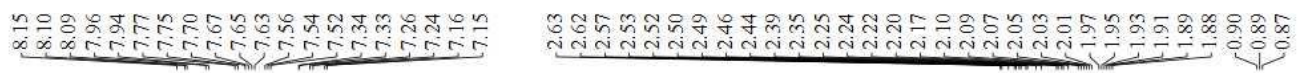

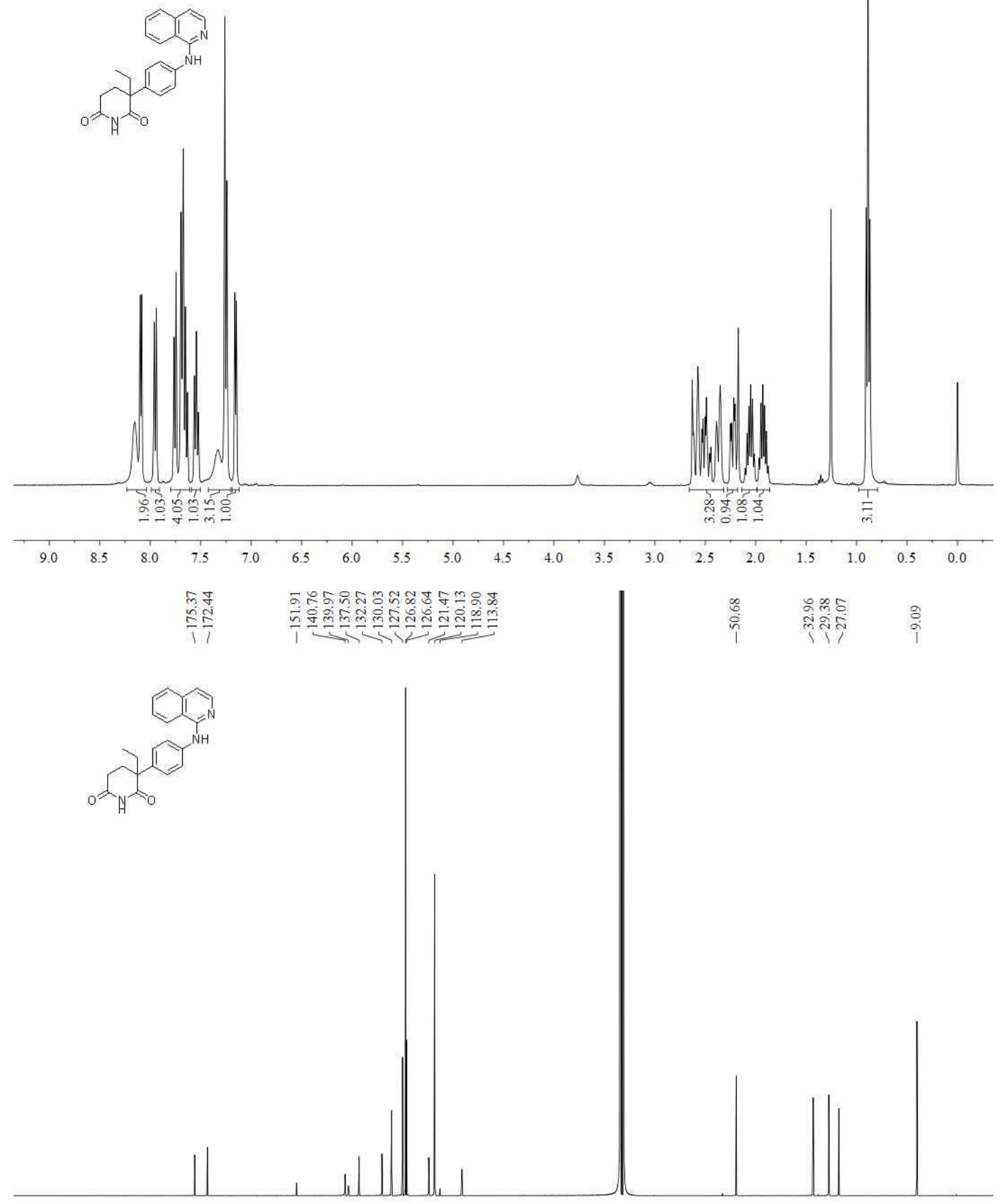

$\begin{array}{lllllllllllllllllllllllllll}210 & 200 & 190 & 180 & 170 & 160 & 150 & 140 & 130 & 120 & 110 & 100 & 90 & 80 & 70 & 60 & 50 & 40 & 30 & 20 & 10 & 0\end{array}$ 
(2R,3R,4S,5R,6S)-2-(hydroxymethyl)-6-(4-(isoquinolin-1-ylamino)phenoxy)tetrahydro-2Hpyran-3,4,5-triol (82c)

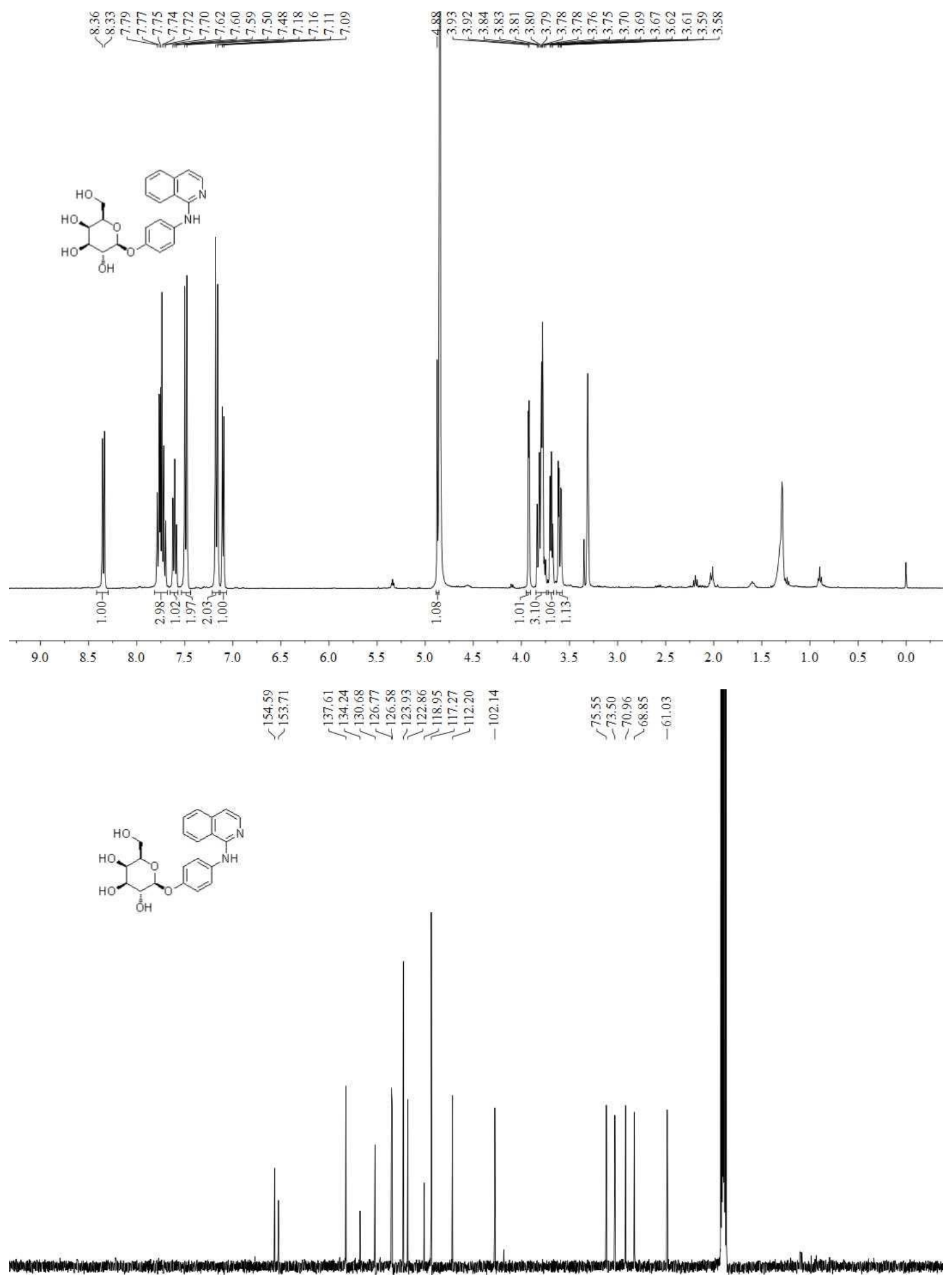

$\begin{array}{llllllllllllllllllllllll}210 & 200 & 190 & 180 & 170 & 160 & 150 & 140 & 130 & 120 & 110 & 100 & 90 & 80 & 70 & 60 & 50 & 40 & 30 & 20 & 10 & 0\end{array}$ 
(5S,8R,9S,10S,13S,14S,17S)-3-(isoquinolin-1-ylamino)-10,13,17-trimethylhexadecahydro-1 H-cyclopenta[a]phenanthren-17-ol (83c)

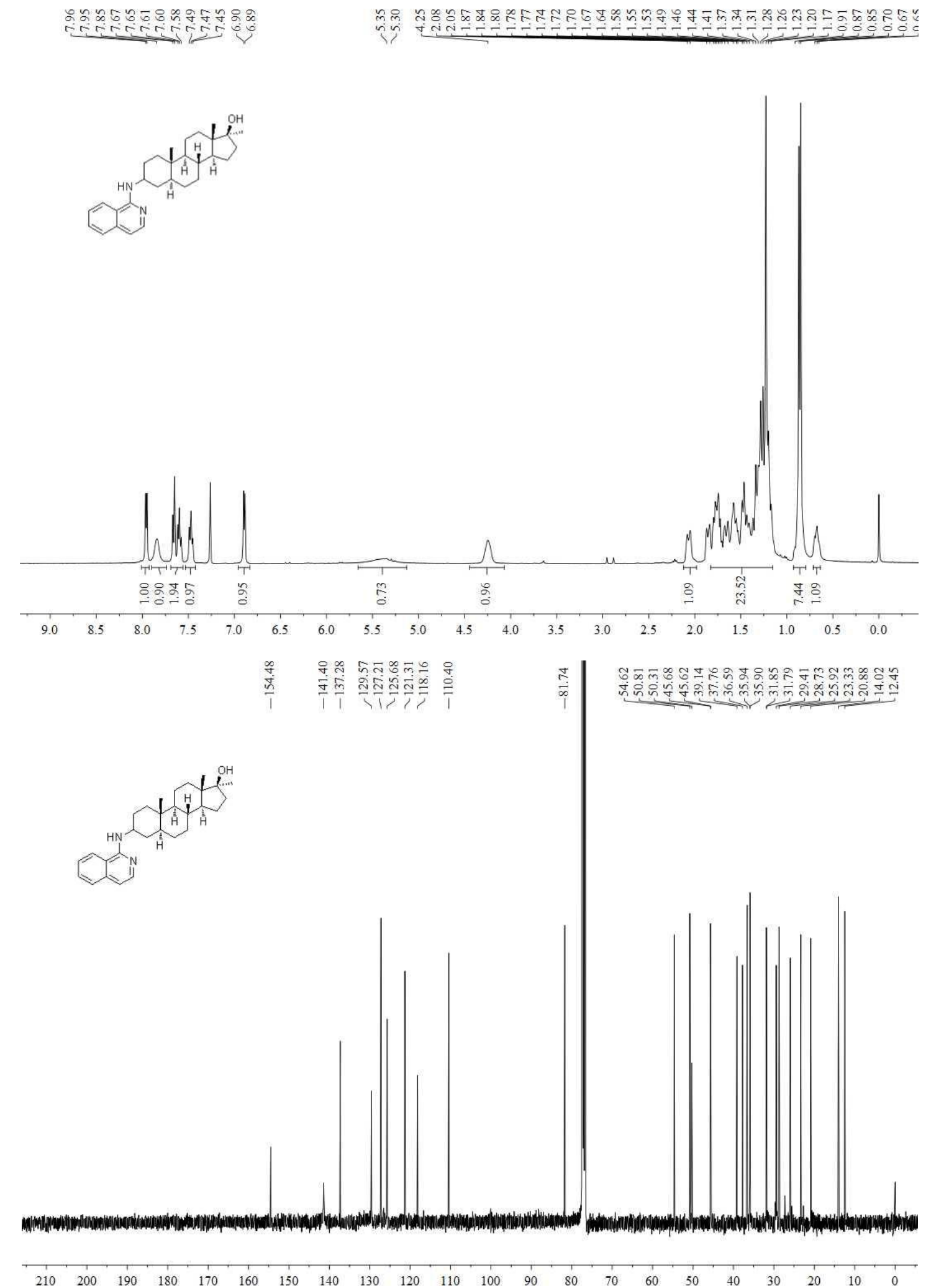


(3S,8R,9S,10R,13S,14S)-17-(isoquinolin-1-ylamino)-10,13-dimethyl-2,3,4,7,8,9,10,11,12,13,1 4,15,16,17-tetradecahydro-1H-cyclopenta[a]phenanthren-3-ol (84c)

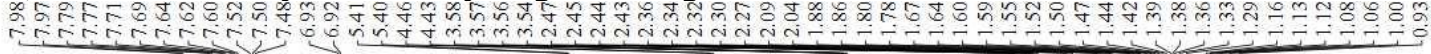

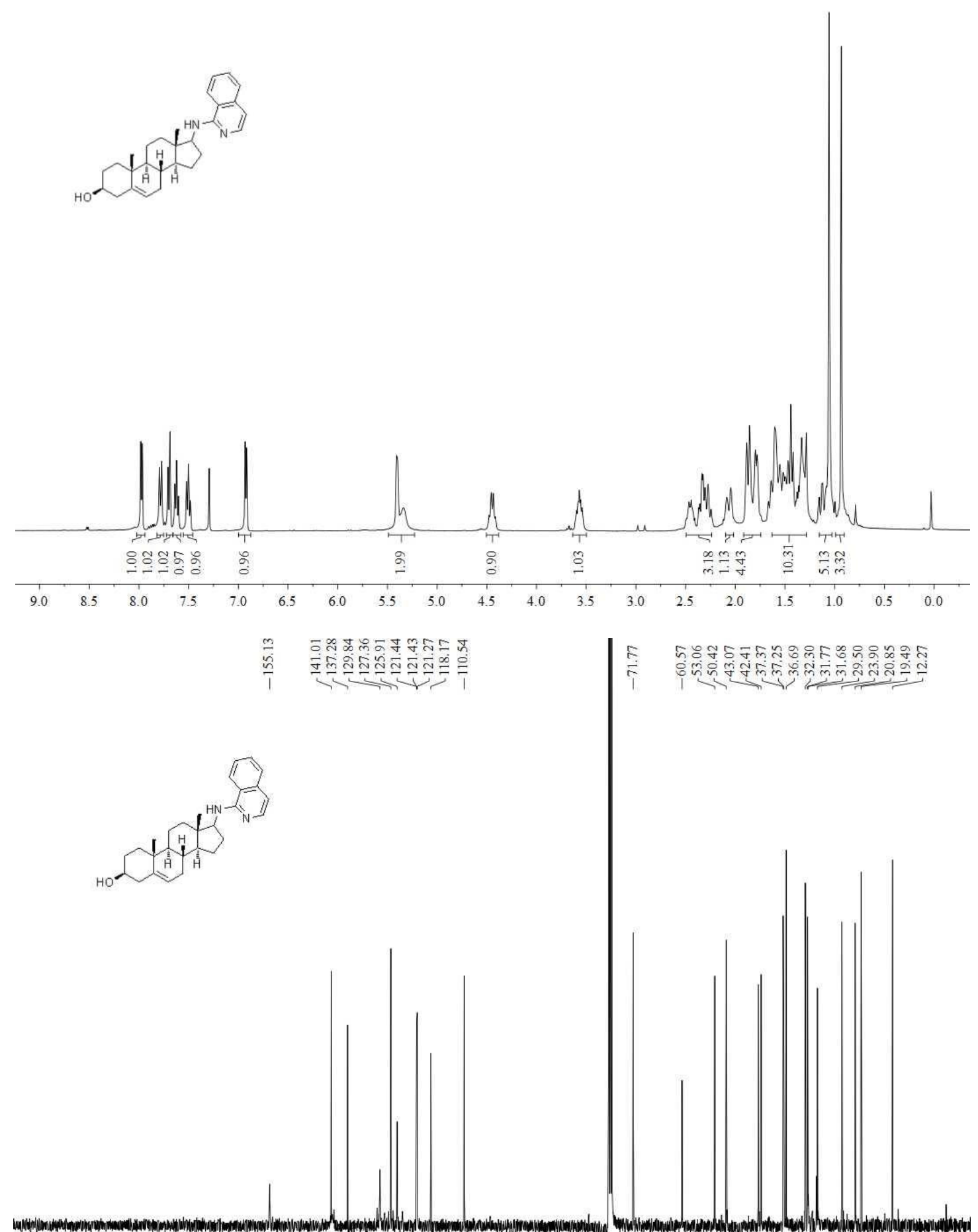




\section{$N$-methylquinolin-4-amine (85c)}

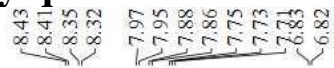<smiles>[C]1CC2CCCC2C1</smiles>

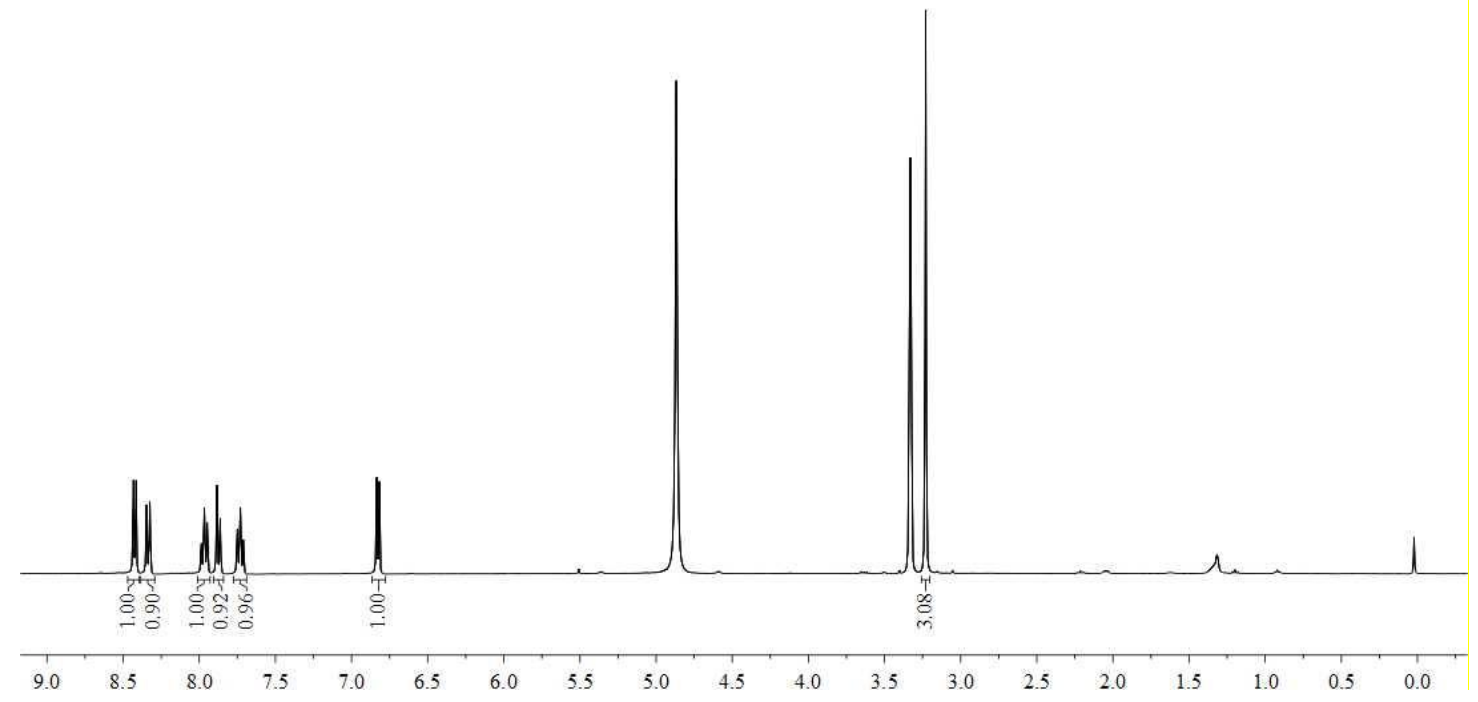

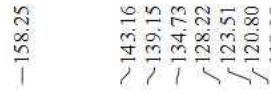<smiles>c1ccccc1</smiles>

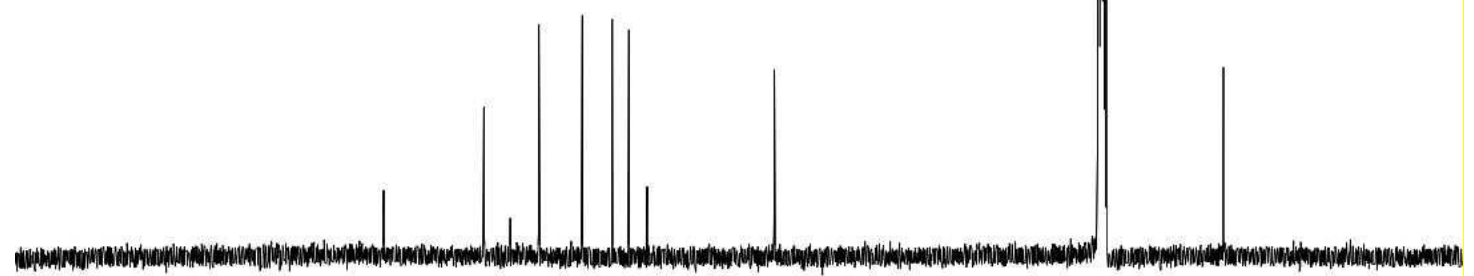

$\begin{array}{lllllllllll}210 & 200 & 190 & 180 & 170 & 160 & 150 & 140 & 130 & 120 & 110\end{array}$

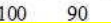

80

60

40 